SOFIA ARAÚJO LIMA

\title{
ANÁLISE DA VIABILIDADE DO USO DE CINZAS AGROINDUSTRIAIS EM MATRIZES CIMENTÍCIAS: ESTUDO DE CASO DA CINZA DA CASCA DA CASTANHA DE CAJU
}

Dissertação apresentada ao Departamento de Arquitetura e Urbanismo da Escola de Engenharia de São Carlos da Universidade de São Paulo, como parte dos requisitos para a obtenção do título de Mestre em Arquitetura e Urbanismo.

Área de Concentração:

Arquitetura, Urbanismo e Tecnologia.

Orientador:

Prof. Dr. JOÃO ADRIANO ROSSIGNOLO 
AUTORIZO A REPRODUÇÃO E DIVULGAÇÃO TOTAL OU PARCIAL DESTE TRABALHO, POR QUALQUER MEIO CONVENCIONAL OU ELETRÔNICO, PARA FINS DE ESTUDO E PESQUISA, DESDE QUE CITADA A FONTE.

Ficha catalográfica preparada pela Seção de Tratamento da Informação do Serviço de Biblioteca - EESC/USP

$$
\text { Lima, Sofia Araújo }
$$

L732a Análise da viabilidade do uso de cinzas agroindustriais em matrizes cimentícias: estudo de caso da cinza da casca da castanha de caju / Sofia Araújo Lima; orientador João Adriano Rossignolo. -- São Carlos, 2008.

Dissertação (Mestrado) - Programa de Pós-Graduação em Arquitetura e Urbanismo e Área de Concentração em Arquitetura, Urbanismo e Tecnologia -- Escola de Engenharia de São Carlos da Universidade de São Paulo, 2008.

1. Resíduos agrícolas. 2. Cinza da casca da castanha de caju. 3. Resíduos agroindustriais. 4. Adições minerais. 5. Matrizes cimentícias. 6. Viabilidade técnica. I. Titulo. 
"Convém não esquecer, contudo, que a realização nobre exige três requisitos fundamentais, a saber: primeiro, desejar; segundo, saber desejar; e terceiro, merecer, ou por outros termos, vontade ativa, trabalho persistente $\mathrm{e}$ merecimento justo".

André Luiz, em Nosso Lar

"Continuem. Nada no mundo pode substituir a persistência. $O$ talento não pode: nada mais comum que um talento não reconhecido. Educação não pode: 0 mundo está cheio de fracassos educados. Só a persistência é onipotente". 
Aos meus pais, Ângela e Edmilson.

Ao meu esposo Elievam, companheiro durante todo o período de elaboração deste trabalho.

Dedico. 


\section{AGRADECIMENTOS}

A Deus, primeiramente, e à Espiritualidade Maior pelo amparo de cada dia.

À toda minha família, que mesmo de longe, enviaram-me sempre mensagens de força e incentivo, em especial à Sofia Dantas e Júlia Lima, minhas avós; Luzia, Almir, Cristina, Neuza, Fátima, Adelino, Grangeiro, Joaquim e Don Carlos, meus tios; José Neto e Edmilson Filho, meus irmãos; Irenir e Leda, minhas "tias" de coração.

Às famílias Rocha e Bessa, que também de longe, estiveram sempre na torcida: Fátima Rocha, Elievan Bessa, Felipe, Juliana, Adriani, Hilda, Lucas, Letícia, Bebeta, Pedro Neto, Gagá, Giovani, Sueli, Afonso, Diana, Vônia, Renata, Marta, Vanda e tantos outros.

Ao prof. João Adriano Rossignolo, pela orientação paciente e enriquecedora, pelo incansável incentivo, pela confiança e amizade, sendo sempre um ponto de apoio, equilíbrio e aprendizagem.

Aos professores Osny Pellegrino Ferreira, Valdir Schalch, Javier Mazariegos Pablos, Holmer Savastano Jr. e Almir Sales, pela valiosa contribuição a esta pesquisa.

Aos amigos, Nájila Rejanne e Adeildo Cabral, professores do Centro Federal de Educação Tecnológica do Ceará, pela amizade sincera e pela importante orientação em minha formação técnico-científica desde 2003.

Aos fiéis e amados amigos Gerlânia Baraúna, Sávio Pinheiro e Fernanda Marciano, pela amizade incondicional. Não podia esquecer também dos amigos Fernando Portela, Marisley Almeida, Aline Silva, Jahyr Teodoro, Helenice Sacht, Paula Donegan, Diogo Collela, Vanessa Yuassa, André Cunha, Ana Elisa, Francisco Arcelino, Andréa Júlia, Tatiana Renata, Bruno Bertoncini e tantos outros, pela amizade são-carlense tão enriquecedora.

À Fundação de Amparo à Pesquisa do Estado de São Paulo (FAPESP), pela concessão da bolsa de estudos e pelo auxílio financeiro a esta pesquisa.

Aos técnicos do Laboratório de Construção Civil da EESC/USP, Paulo Pratavieira (Paulão), Sérgio e Paulo Alberto (Tico). Aos funcionários do Departamento de Arquitetura e Urbanismo (SAP/EESC/USP), Marcelinho, Geraldo, Osvaldo e Ceneviva.

A todos aqueles que contribuíram de alguma forma para a realização deste trabalho, deixo registrado meus sinceros agradecimentos. 


\section{LIMA, S. A. Análise da viabilidade do uso de cinzas agroindustriais em matrizes} cimentícias: estudo de caso da cinza da casca da castanha de caju. 2008. 139f. + apêndices. Dissertação (Mestrado) - Escola de Engenharia de São Carlos, Universidade de São Paulo. São Carlos, 2008.

Atualmente, o aproveitamento de resíduos na construção civil tem sido estimulado devido essa atividade ser um dos maiores consumidores de materiais naturais em seus processos e produtos. As cinzas agroindustriais ocupam lugar de destaque dentre os resíduos com possibilidades de aplicação em materiais cimentícios, pois algumas, como a cinza da casca do arroz, apresentam propriedades pozolânicas, contribuindo para a redução do consumo de cimento Portland. Nesse sentido, esta pesquisa teve como objetivo principal a avaliação da viabilidade técnica do uso de cinza agroindustriais em matrizes de cimento Portland, tendo como estudo de caso a cinza da casca da castanha de caju (CCCC). As cascas das castanhas de caju, resíduos da produção das castanhas, são incorporadas novamente ao processo, e, nas caldeiras, irão gerar calor para a decorticação de novas castanhas. A CCCC é o resíduo colhido no fundo da grelha das caldeiras, resultante da queima das cascas de castanhas. Atualmente, esse resíduo é utilizado como adubo em plantações de caju, sendo uma pequena parte destinada à aterros sanitários comuns. Foram realizados ensaios para avaliar a composição físico-química da CCCC; analisar o potencial pozolânico; analisar a retração por secagem e da profundidade de carbonatação de argamassas confeccionados com CCCC; e determinar a capacidade de estabilização/solidificação da CCCC pela matriz cimentícia. A partir dos resultados, pode-se apontar como características principais da CCCC: i) não apresentar potencial pozolânico; ii) favorecer a incorporação de ar em matrizes cimentícias; iii) ocasionar solubilidade de metais pesados e Fenol quando no estado in natura; iv) contribuir para o aumento da retração por secagem e da carbonatação em argamassas; v) liberar Cromo e Sódio mesmo quando estabilizada/solidificada em pastas em teores de até $10 \%$ de substituição. Por essas considerações, a CCCC não apresentou viabilidade técnica para uso em matrizes cimentícias.

Palavras-chave: Cinza da casca da castanha de caju; Resíduos agroindustriais; Adições minerais; Matrizes cimentícias; Viabilidade técnica. 


\section{ABSTRACT}

LIMA, S. A. Feasibility analysis of using agroindustrial ashes in cementitious materials: case study of ash of the rind of the cashew nut. 2008. 139f. + appendix. Dissertation (Master's degree) - Engineering School of São Carlos, University of São Paulo. São Carlos, Brazil, 2008.

Nowadays, the use of wastes on civil building has been stimulated for it to be one of most consumers of raw materials in their processes and products. The agroindustrial ashes have a prominent place among the wastes with possibilities of application in cementitious materials, because some ashes, such rice husk ash, have pozzolanic activity, and they contribute to reduce the Portland cement consumption. This work aimed to study the evaluation of technical feasibility of the agroindustrial ashes for use in Portland cement matrices, using the ash of the rind of the cashew nut (ARCN) as case study. The rinds of cashew nut (wastes of nuts' production) are burned again during the heating process, and in boilers, they will generate heat for shelling other nuts. The ARCN is the waste collected from the boiler grid, resulted from burning of the rind of nuts. This waste is used as compostes in plantings of cashew and a little part of it is dumped in landfill sites. Tests were made for evaluation of physico-chemical composition of ARCN; for analyse of pozzolanic activity; for analyse of drying shrinkage and carbonation in mortars made with ARCN; and the analyse of the stabilization/solidification of ARCN in pastes. After the analyse of results, it may be pointed as main features of ARCN: i) not show pozzolanic activity; ii) to promote air entrainment in cementitious matrices; iii) to cause heavy metals and Phenol solubilization as in raw state; iv) to increase the drying shrinkage and carbonation in mortars; and, v) to let out Chrome and Sodium when stabilizated/solidificated in pastes in levels of replacement until $10 \%$. For all these considerations, the ARCN haven't showed technical feasibility for use in cementitious matrices.

Key words: Ash of the rind of the cashew nut; Agroindustrial ashes; Mineral admixtures; Cementitious matrices; Technical feasibility. 


\section{LISTA DE FIGURAS}

Figura 2.1 - Fabricação da telha produzida com resíduos das embalagens longa vida. 25

Figura 2.2 - Esquema simplificado do processo de análise de desempenho com ênfase na viabilidade técnica proposto e utilizado por esta pesquisa 26

Figura 2.3 - Mecanismos da ação pozolânica. 30

Figura 2.4 - Micrografia eletrônica de varredura da cinza de casca de arroz queimada a $560^{\circ} \mathrm{C}$. 32

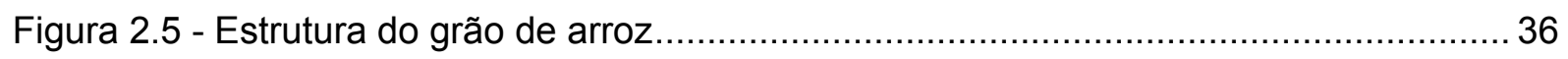

Figura 2.6 - Variação do índice de atividade pozolânica com o grau de moagem ................ 40

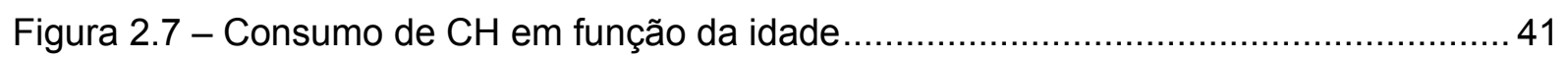

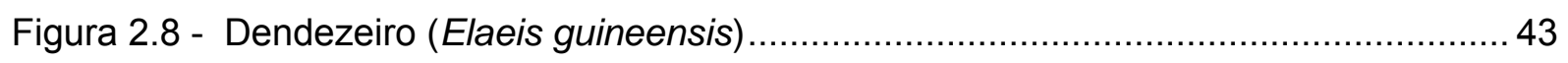

Figura 2.9 - Cinza da cama sobreposta de suínos .................................................. 43

Figura 2.10 - Evolução da produtividade da cana-de-açúcar no Brasil ............................. 44

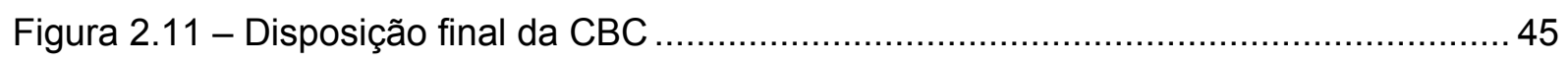

Figura 2.12 - Aumento na demanda de água versus teor de cinza (resíduo de madeira) ..... 50

Figura 3.1 - Caju: pedúnculo (cor amarelada) e castanha (fruto verdadeiro). 57

Figura 3.2 - Cascas de castanhas após decorticação: bagaço de pedaços não-uniformes... 58

Figura 4.1 - (a) Corpos-de-prova 50x25mm. (b) Moldagem dos diferentes traços.............. 69

Figura 4.2 - (a) Fragmento de amostra no almofariz cerâmico. (b) Peneira $n^{\circ} 200 \ldots \ldots \ldots \ldots . . .70$

Figura 4.3 - (a) Amostra de CCCC no moinho de esferas metálicas. (b) Amostra de CCCC embalada e identificada.

Figura 4.4 - (a) Mesa para o Flow Test. (b) Medição do espalhamento da argamassa com

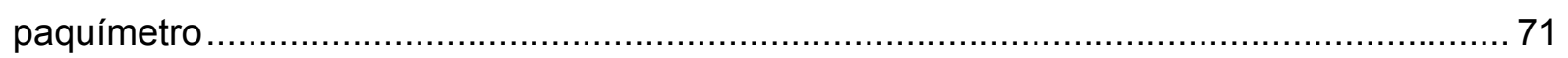

Figura 4.5 - Moldagem dos corpos-de-prova de argamassa ...................................... 73

Figura 4.6 - Materiais utilizados - (a) Amostra de CCCC e CP ARI PLUS. (b) Quarteamento

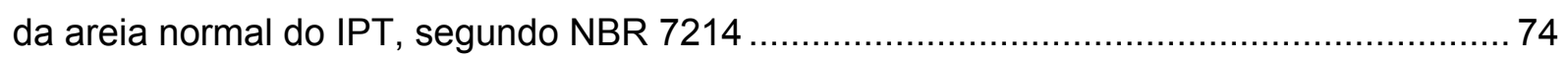

Figura 4.7 - Corpos-de-prova mantidos em estufa por 27 dias..................................... 74 
Figura 4.8 - Cura dos corpos-de-prova nas primeiras 24h em câmara seca de temperatura controlada

Figura 4.9 - Ensaio de Retração (a) Forma para moldagem. (b) Moldagem e adensamento. 79

Figura 4.10 - (a) Corpos-de-prova identificados e armazenados em câmara seca de temperatura controlada. (b) Aparelho de medição da retração - Unidade: 1/100mm. 80

Figura 5.1 - Micrografia com aumento de 10000 vezes 94

Figura 5.2 - Micrografia com aumento de 3500 vezes 94

Figura 5.3 - Micrografia com aumento de 1000 vezes 94

Figura 5.4 - Difratograma de raios $X$ da CCCC in natura 95

Figura 5.5 - Ensaios de tempo de moagem - peneira $n^{\circ} 250$ 97

Figura 5.6 - Ensaios de tempo de moagem - peneira $\mathrm{n}^{\circ} 200$ 97

Figura 5.7 - CCCC aderida às laterais e às esferas do moinho para os tempos de moagem acima de 10 horas 98

Figura 5.8 - Resistência à compressão aos 28 dias - ensaio de índice de pozolanicidade .100 Figura 5.9 - Resistência à compressão aos 91 dias - ensaio de índice de pozolanicidade .100 Figura 5.10 - (a) Aspecto dos corpos-de-prova ainda úmidos após 7 dias de cura. (b) Capeamento com enxofre e desintegração dos corpos-de-prova 101

Figura 5.11 - Ruptura dos corpos-de-prova de argamassa - ensaio NBR 5752 102

Figura 5.12 - Valores do pico de P (Portlandita, CH), em 18, $1^{\circ} 2 \theta$ para as pastas analisadas 103

Figura 5.13 - Valores do pico de E (Etringita) em $32,97^{\circ} 2 \theta$ para as pastas analisadas ......104 Figura 5.14 - Valores do pico de C (Calcita), em $32,20^{\circ} 2 \theta$ para as pastas analisadas .......104 Figura 5.15 - Difratograma de raios X da Pasta $14-20 \%$ de CCCC ...............................105

Figura 5.16 - Difratograma de raios X da Pasta $15-30 \%$ de CCCC. 105

Figura 5.17 - Variação da massa específica final em relação a massa específica teórica amostras do grupo A (cinza moída e peneirada) em relação a amostra de referência (TRO) 106

Figura 5.18 - Variação da massa específica final em relação a massa específica teórica amostras do grupo B (cinza moída) em relação a amostra de referência (TR0)...... 106 
Figura 5.19 - Teor de ar incorporado - Grupo A .................................................... 107

Figura 5.20 - Teor de ar incorporado - Grupo B ................................................... 107

Figura 5.21 - Evolução da resistência à compressão em função dos teores de CCCC Grupo A. 108

Figura 5.22 - Evolução da resistência à compressão em função dos teores de CCCC Grupo B 108

Figura 5.23 - Resistência à compressão média aos 91 dias dos grupos A e B 109

Figura 5.24 - Influência do fator água/cimento e do ar incorporado sobre a resistência à compressão 110

Figura 5.25 - Valores de retração $\left(\times 10^{6}\right)$ - Grupo B (cinza moída) 112

Figura 5.26 - Valores de retração $\left(\times 10^{6}\right)$ - Grupo C (cinza moída e peneirada). 112

Figura 5.27 - Valores da profundidade de carbonatação - Grupo A (cinza moída). 115

Figura 5.28 - Valores da profundidade de carbonatação - Grupo B (cinza moída e peneirada). 115

Figura 5.29 - Esquema tridimensional da relação entre carbonatação, resistência à compressão e porosidade em concretos. 116

Figura 5.30 - Concentração no extrato solubilizado - Sódio 118

Figura 5.31 - Concentração no extrato solubilizado - Cromo Total. 118 


\section{LISTA DE TABELAS}

Tabela 2.1 - Características físicas de diversos materiais. 31

Tabela 2.2 - Exigências químicas e físicas dos materiais pozolânicos 33

Tabela 2.3 - Características físicas e atividade pozolânica de algumas cinzas vegetais 35

Tabela 2.4 - Composição química e propriedades físicas da cinza residual do bagaço da cana-de-açúcar e do quartzo moído.... 46

Tabela 2.5 - Composição química - CCA e CBC 47

Tabela 2.6 - Medições por DrX, consumo de CH 47

Tabela 2.7 - Resultados do ensaio de resistência à compressão - CBCA 48

Tabela 2.8 - Análise química da cinza da serragem 49

Tabela 2.9 - Ensaio de resistência à compressão - cinza da serragem 49

Tabela 2.10 - Resistência à compressão de corpos-de-prova confeccionados com a cinza da casca do eucalipto - MPa 51

Tabela 2.11 - Análise química da cinza da casca de eucalipto calcinada a $1000^{\circ} \mathrm{C}$. 51

Tabela 2.12 - Resultados dos ensaios de atividade pozolânica - CCCP..... 53

Tabela 3.1 - Posição do setor de exportações de castanha de caju no Estado do Ceará .... 56

Tabela 3.2 - Subprodutos agrícolas: produção total e volume de cinzas gerado 60

Tabela 4.1 - Resumo dos ensaios e a metodologia utilizada 62

Tabela 4.2 - Propriedades físicas - CPV ARI PLUS 63

Tabela 4.3 - Composição química do cimento CPV ARI PLUS 64

Tabela 4.4 - Características físicas da sílica ativa 64

Tabela 4.5 - Composição química da sílica ativa 65

Tabela 4.6 - Composição química da cal hidratada $\mathrm{CH}-\mathrm{III}$..... 65

Tabela 4.7 - Dados para análise de pastas por DrX 69

Tabela 4.8 - Dados referentes ao ensaio de avaliação do tempo ótimo de moagem. 70

Tabela 4.9 - Quantidade de material. Moldagem dos corpos-de-prova 72 
Tabela 4.10 - Traços - Ensaio pozolanicidade com cimento Portland 73

Tabela 4.11 - Proporção dos materiais utilizados no ensaio de pozolanicidade com a cal .. 75

Tabela 4.12 - Traços e Idades de ruptura - Ensaio de teores de substituição .76

Tabela 4.13 - Dados para moldagem dos corpos-de-prova em argamassa para o ensaio de retração. 79

Tabela 4.14 - Dados para moldagem dos corpos-de-prova em argamassa para o ensaio de carbonatação 81

Tabela 5.1 - Análise química da CCCC 85

Tabela 5.2 - Exigências físicas estabelecidas para materiais pozolânicos 85

Tabela 5.3 - Substâncias encontradas no extrato solubilizado da CCCC e os respectivos limites exigidos pela norma NBR 10006 (Anexo C e Anexo G). 89

Tabela 5.4 - Influência dos metais pesados na reatividade hidráulica e na qualidade do cimento e concreto. 91

Tabela 5.5 - Dados da superfície específica da amostra analisada (CCCC moída 1h)........93

Tabela 5.6 - Demanda de água e Índice de pozolanicidade - CCA ................................. 99

Tabela 5.7 - Demanda de água e Índice de pozolanicidade - CCCC …........................... 99

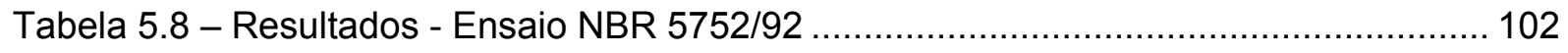

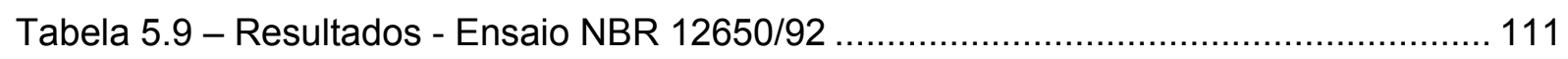

Tabela 5.10 - Valores acima do limite máximo permitido pela NBR 10006 - substâncias encontradas nas pastas e na CCCC in natura 


\section{SUMÁRIO}

RESUMO …

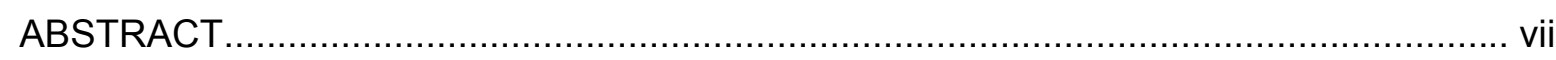

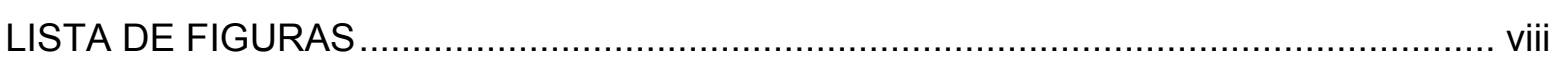

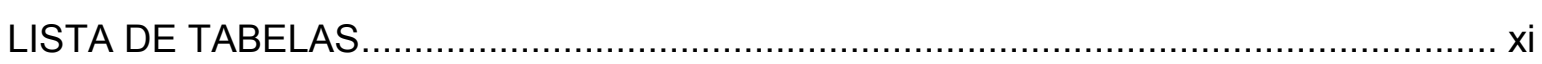

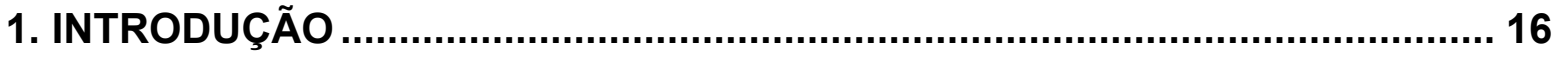

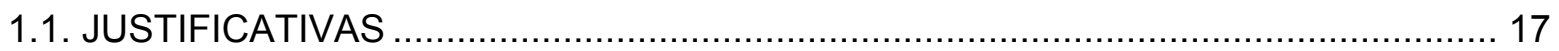

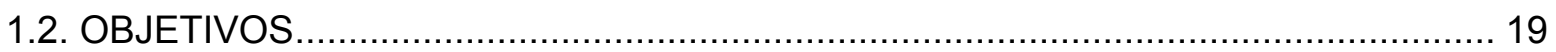

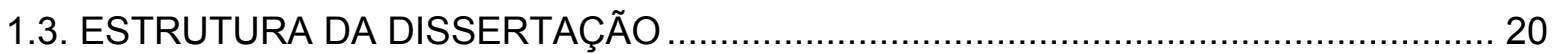

2. O USO DOS RESÍDUOS NA CONSTRUÇÃO CIVIL ...................................... 22

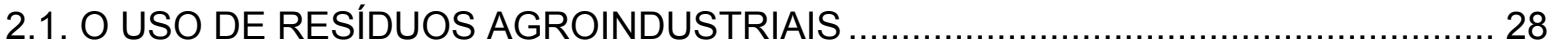

2.2. AS CINZAS AGROINDUSTRIAIS UTILIZADAS EM MATRIZES DE CIMENTO

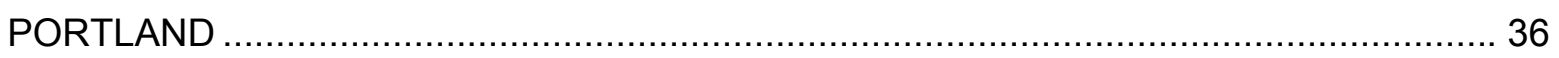

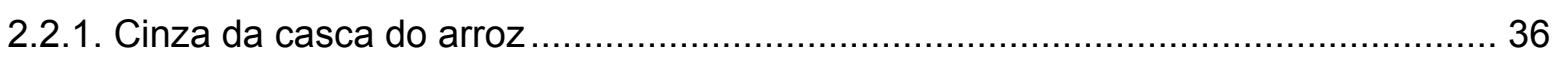

2.2.2. Cinza da casca do coco da palma.............................................................. 42

2.2.3. Cinza da cama sobreposta de suínos ............................................................. 42

2.2.4. Cinza do bagaço da cana-de-açúcar ............................................................... 44

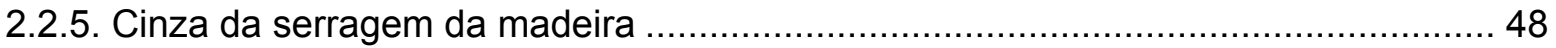

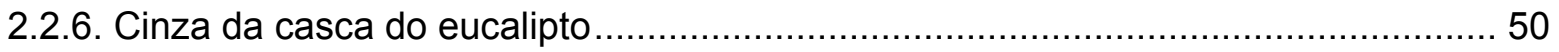

2.2.7. Cinza da casca da castanha-do-pará ............................................................... 52

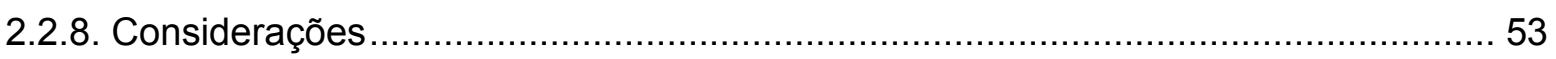

3. A CINZA DA CASCA DA CASTANHA DE CAJU …..................................... 54

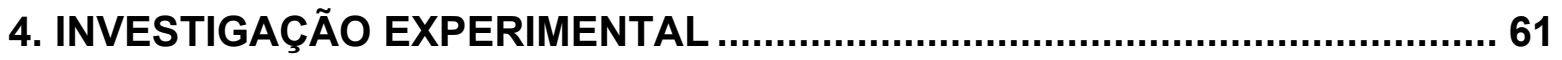

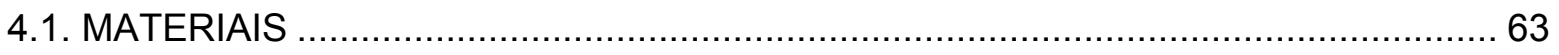

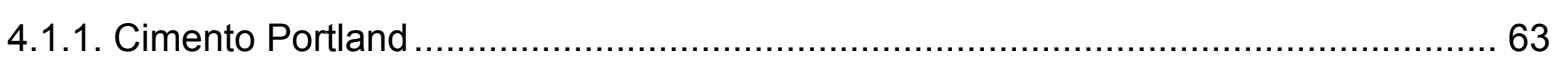

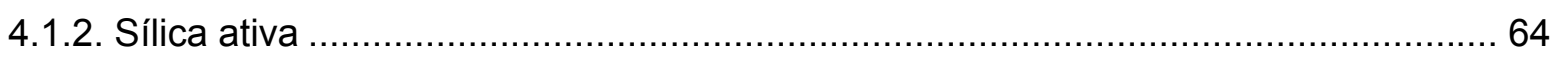

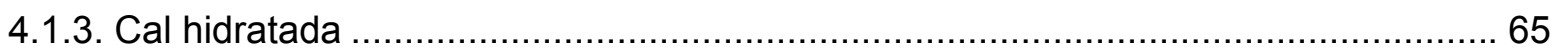

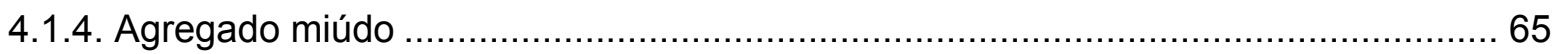

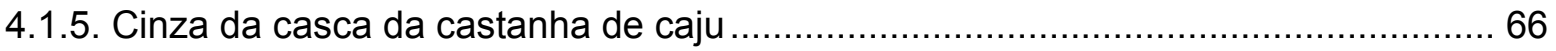

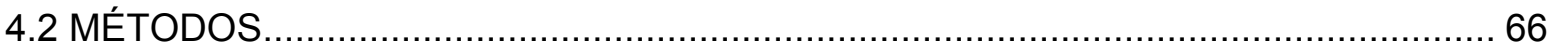

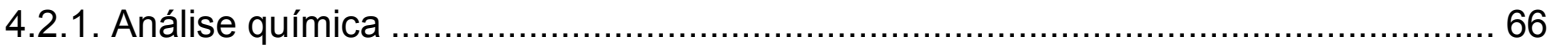


4.2.2. Determinação da massa unitária e da massa específica ....................................... 67

4.2.3. Análise dos extratos lixiviado e solubilizado da CCCC in natura............................. 67

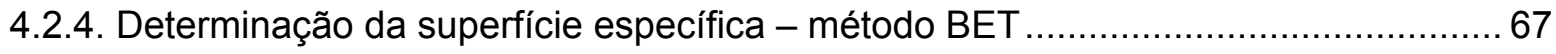

4.2.5. Análise por Microscopia Eletrônica de Varredura - MEV ..................................... 68

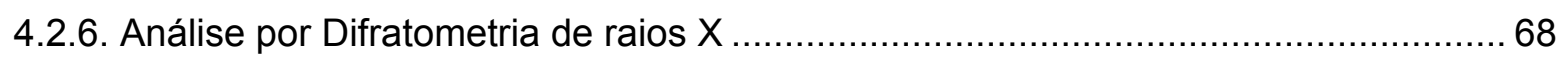

4.2.7. Análise do tempo ótimo de moagem da CCCC ................................................ 70

4.2.8. Análise da pozolanicidade com o cimento Portland ............................................. 73

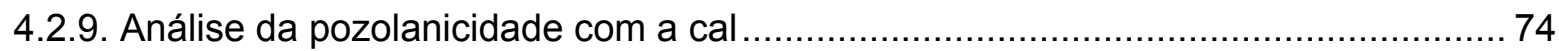

4.2.10. Análise do teor ótimo de substituição da CCCC ................................................ 76

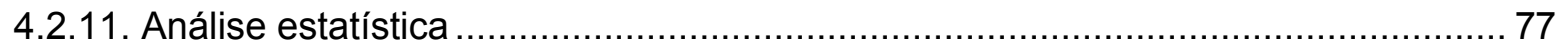

4.2.12. Análise da retração por secagem de materiais pozolânicos ................................. 78

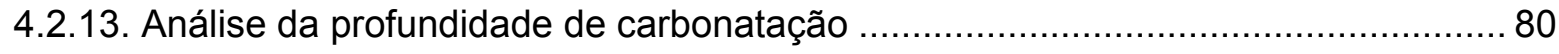

4.2.14. Determinação da capacidade de estabilização/solidificação da CCCC pela matriz

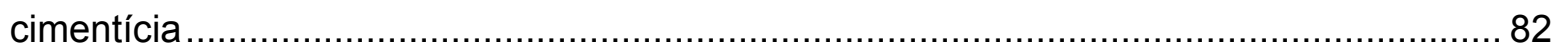

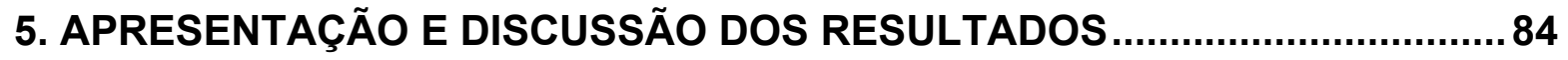

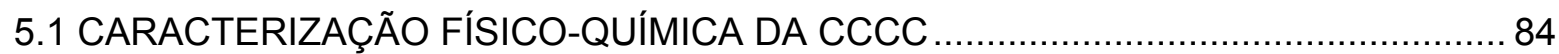

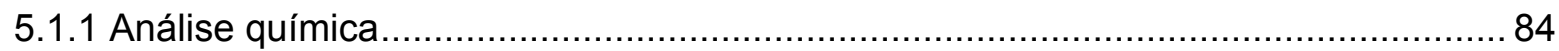

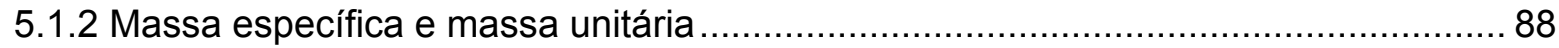

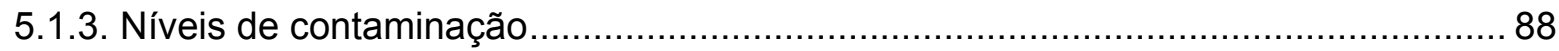

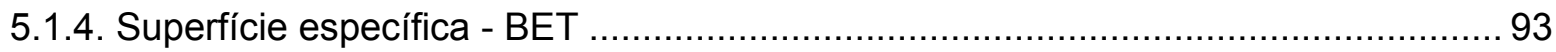

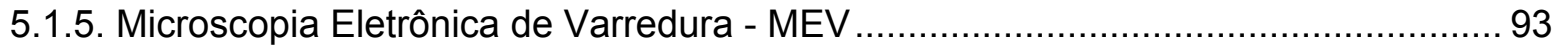

5.1.6. Análise do teor de materiais amorfos por difratometria de raios $X \ldots \ldots \ldots \ldots \ldots \ldots \ldots \ldots . . . . . . . . . . . . . .55$

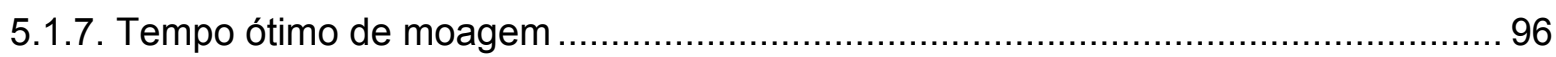

5.2. ANÁLISE DO POTENCIAL POZOLÂNICO DA CCCC ........................................... 101

5.2.1. Atividade pozolânica com a cal e com o cimento Portland .................................... 101

5.2.2. Avaliação da variação do teor de hidróxido de cálcio $(\mathrm{CH})$ em pastas..................... 103

5.2.3. Influência da variação dos teores de substituição .................................................. 105

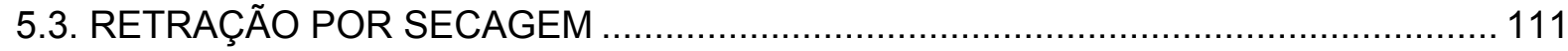

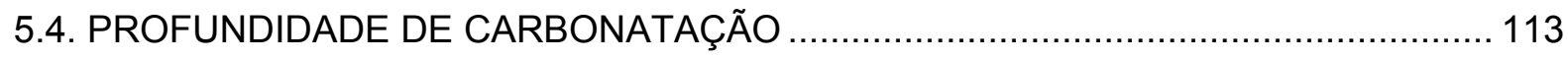

5.5. ESTABILIZAÇÃO/SOLIDIFICAÇÃO DA CCCC PELA MATRIZ CIMENTÍCIA ............ 116

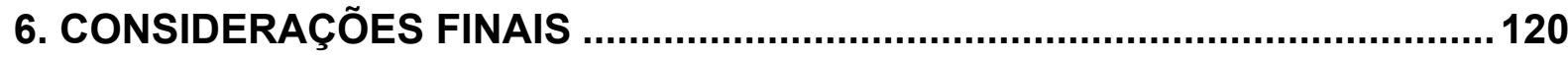

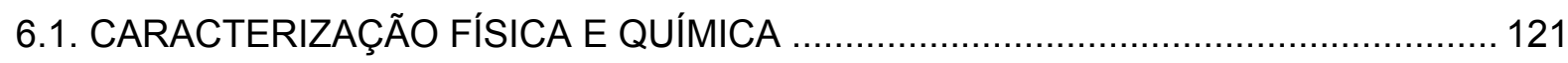

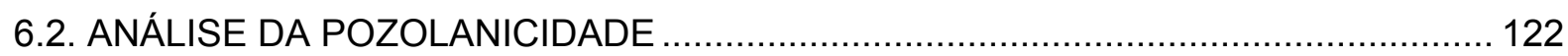

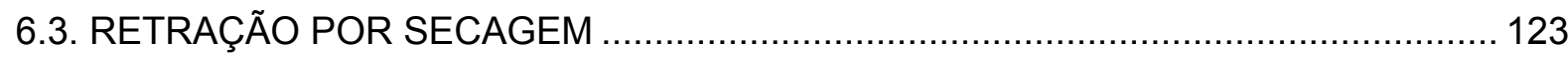

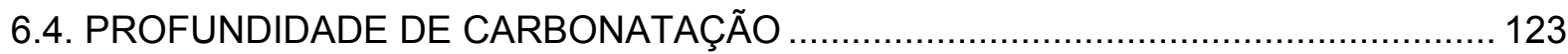




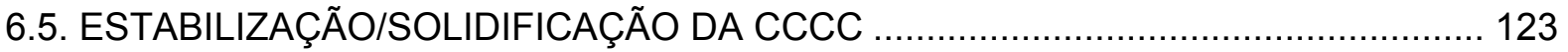

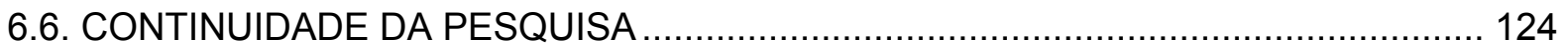

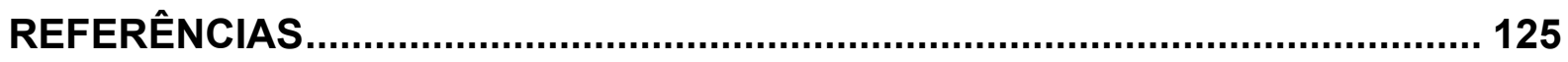

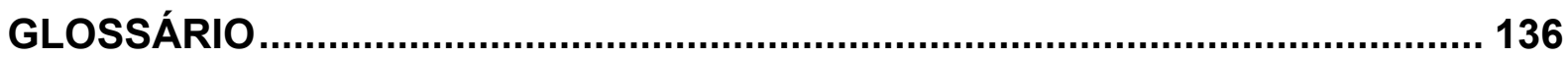

APÊNDICE A - Inferência Estatística ........................................................ 140

APÊNDICE B - Resultados - Solubilização e Lixiviação................................ 145

APÊNDICE C - Difratogramas das pastas.................................................. 147

APÊNDICE D - Dados - Análise do teor de substituição .............................. 153

APÊNDICE E - Figuras - Ensaio de carbonatação ...................................... 156

APÊNDICE F - Resultados - Solubilização das pastas ................................ 159 


\section{Capítulo}

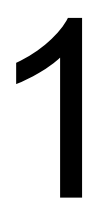

\section{INTRODUÇÃO}

A preocupação com o consumo energético mundial, que vem se agravando desde a Crise do Petróleo ${ }^{1}$ iniciada em 1973, tem estimulado, desde então, a busca por fontes de energias renováveis que diminuam o consumo de combustíveis fósseis, esgotáveis e altamente poluentes, e que sejam produtos sustentáveis em acordo com as normas ambientais vigentes.

Sabe-se que a queima de derivados de combustíveis fósseis (petróleo, carvão, etc.) está acelerando o aumento da temperatura do planeta, fenômeno conhecido pela comunidade científica como aquecimento global. Apesar de não ser recente, somente agora tem demandado preocupação dos países desenvolvidos, até então alheios aos apelos da comunidade científica.

Há pouco tempo, esses países associavam as palavras "ecologia", "sustentabilidade" e "preservação do meio ambiente" a uma ameaça, algo que pudesse frear o próprio crescimento econômico. Hoje, previsões alarmantes atestam que esse almejado crescimento (lucro para as grandes potências mundiais) pode ser sensivelmente abalado pelo aumento da temperatura média do globo terrestre.

Notícias veiculadas na mídia $^{2}$ alertam para a necessidade urgente de se diminuirem as emissões de carbono na atmosfera. Em contato com o oxigênio, o carbono se transforma em $\mathrm{CO}_{2}$ ampliando o efeito estufa e contribuindo, progressivamente, para o aumento da temperatura média do globo terrestre. Os resultados são o derretimento das geleiras, enchentes cada vez mais freqüentes nas regiões subtropicais, secas na Amazônia brasileira, aumento da temperatura média dos oceanos, perda da biodiversidade, entre

\footnotetext{
${ }^{1}$ Crise do Petróleo. Artigo disponível para consulta em <http://www.brasilescola.com/historiag/ petroleo.htm>. Acesso em $12 \mathrm{fev} 07$.

${ }^{2}$ Reportagem exibida no programa Fantástico, da Rede Globo, baseado em documentário da rede BBC, Climate Chaos, em 14jan07.
} 
outros (GREENPEACE, 1992). Tais efeitos podem frear qualquer tipo de desenvolvimento humano, seja ele na escala econômica ou social. Por esses motivos, a busca por materiais alternativos, o desenvolvimento de materiais menos poluentes ou que utilizem menos matérias-primas naturais, a reutilização de resíduos sólidos e a diminuição da emissão de gás carbônico são algumas medidas necessárias para o atual cenário mundial.

Tomando por base as proposições discutidas até o presente momento por este trabalho, originou-se a motivação para o desenvolvimento desta pesquisa, no qual se pudesse contribuir para o contínuo crescimento de novas tecnologias em equilíbrio com as exigências de um desenvolvimento mais sustentável.

Os subprodutos de origem vegetal, notadamente os subprodutos agroindustriais, resíduos ou cinzas processadas, vêm sendo estudados para utilização como combustíveis, fertilizantes, estabilizantes de solos e para produção de argamassas e concretos.

Este trabalho apresenta como proposta estudar a viabilidade do uso de cinzas agroindustriais em matrizes cimentícias, em relação as propriedades microestruturais, físicoquímicas, mecânicas e de durabilidade, tendo como estudo de caso a cinza da casca da castanha de caju.

Elaborou-se, primeiramente, uma revisão atual do panorama da utilização de resíduos, do uso desses materiais na construção civil, dos resíduos de natureza agroindustrial, e dos subgrupos das cinzas e sua potencial aplicação em matrizes de cimento Portland, focando nos aspectos mais relevantes estudados pelos pesquisadores dessa área.

\subsection{Justificativas}

Como forma de justificar o desenvolvimento deste trabalho, apresentam-se diversos impactos previstos no âmbito científico, tecnológico, social e ambiental. Essas proposições atuam no sentido de comprovar a necessidade de estudos que contribuam para aprimoramento da tecnologia e aplicação de cinzas de origem agroindustrial na produção de componentes destinados à construção civil.

a) Científico: Com a aplicação de resíduos de origem agroindustrial na produção de componentes para a construção civil será possível a investigação de novas soluções tecnológicas pertinentes a argamassas e concretos confeccionados com resíduos, 
principalmente em relação ao estudo microestrutural, físico-químico e mecânico de matrizes cimentícias. É importante salientar que para uma efetiva contribuição e transferência tecnológica torna-se imprescindível a produção de conhecimento científico pertinente a novos materiais para uso na construção civil, desde os aspectos microestruturais até aos relacionados à durabilidade e à interação com outros materiais convencionais.

b) Técnico: A tecnologia do uso das cinzas na construção civil, investigada com êxito por Santos (1997), Kreuz et al. (2002), Rocha \& Cheriaf (2003), Prudêncio Jr. et al. (2003), entre outros, serve de embasamento para o desenvolvimento da pesquisa com a cinza da casca da castanha do caju, na busca da consolidação desta, como produto atual e viável na produção de elementos de construção alternativos.

c) Social: O resíduo da casca da castanha é subproduto do caju, fruto típico da região Nordeste, cuja cultura é responsável por metade das áreas cultiváveis pela agroindústria no Nordeste do Brasil. De acordo com boletim da CONAB ${ }^{3}$ - Companhia Nacional de Abastecimento, a cajucultura é de fundamental importância para a economia do Ceará e do país, e desponta como o primeiro produto da pauta de exportação desse Estado, gerando divisas e empregos no campo e nas indústrias. $O$ parque industrial de beneficiamento de castanha de caju, que gira em torno de 300 mil toneladas por ano, absorve toda a produção do Estado, e inclusive importa dos estados vizinhos. A descoberta de um valor agregado às cinzas, que outrora iriam para aterros sanitários, gera a expectativa de criação de novos postos de trabalho e a inserção de um novo nicho econômico para os subprodutos da cajucultura brasileira.

d) Ambiental: Quando as propriedades pozolânicas ou aglomerantes de um material são tais que ele pode ser utilizado como substituto parcial do cimento Portland, isso resulta numa economia significativa de energia e custo (MEHTA \& MONTEIRO, 1994).

Neville (1992) acrescenta que o cimento Portland mostra-se como um material de custo elevado dependente de alto consumo de energia e de matérias-primas e que, no futuro, devem ser empregados cada vez mais materiais alternativos que possam produzir concretos mais econômicos e com melhor desempenho.

3 CONAB (2007) Castanha de Caju. Disponível em: <http://www2.conab.gov.br/download/sureg/ce/ conjunturacastanhadecaju.pdf>. Acesso em 11 Abr. 2007. 
Deve-se salientar que para cada tonelada de cimento produzido gera-se uma tonelada de $\mathrm{CO}_{2}$, contribuindo, assim, com $7 \%$ de todo $\mathrm{CO}_{2}$ que é lançado na atmosfera anualmente (BOLETIM QUANTUM, 2003; MEHTA, 1999). Além da poluição, a produção de cimento utiliza $884 \mathrm{Kcal}$ para cada tonelada produzida (LOHTIA in RAMACHANDRAN, 1995).

\subsection{Objetivos}

A presente pesquisa apresenta como objetivo geral a análise da viabilidade do uso de cinzas agroindustriais em matrizes cimentícias, tendo como estudo de caso a cinza da casca da castanha de caju.

Esta pesquisa, ao abordar a análise da viabilidade do uso da cinza da casca da castanha de caju (CCCC) como adição mineral em matrizes cimentícias, apresenta os seguintes objetivos específicos:

a) Caracterização química e física da CCCC:

- Relação de óxidos por análise química;

- Massa específica e unitária;

- Análise do teor de materiais amorfos por difratometria de raios X;

- Análise da superfície específica pelo método BET;

- Análise por Microscopia Eletrônica de Varredura - MEV;

b) Verificação dos níveis de contaminação da CCCC:

- Ensaio de Solubilização (NBR 10005);

- Ensaio de Lixiviação (NBR 10006);

c) Avaliação do tempo ótimo de moagem da CCCC, utilizando moinho de esferas metálicas;

d) Analise do potencial pozolânico da CCCC:

- Determinação o índice de atividade pozolânica com a cal (NBR 5751);

- Determinação o índice de atividade pozolânica com o cimento (NBR 5752); 
- Avaliação da variação do teor de hidróxido de cálcio $(\mathrm{CH})$ em pastas de cimento Portland, utilizando a técnica da difratometria de raios $X(\mathrm{DrX})$, com vários teores de substituição de cinza (0 a 30\%).

e) Determinação de teores ótimos de adição de CCCC em argamassa de cimento Portland;

- Avaliação dos valores de resistência à compressão (NBR 5739) em argamassas 1:3 (areia normal IPT) em varias idades $(14,28,56$ e 91 dias), utilizando teores de CCCC entre $0 \%$ e $30 \%$;

f) Avaliação da retração por secagem (NBR 12650)

- Avaliação da retração por secagem em corpos-de-prova prismáticos (4x4x16cm), em várias idades $(7,14,28,56$ e 119 dias) utilizando teores de CCCC entre 0 e $30 \%$, além dos traços recomendados pela norma;

g) Avaliação da profundidade de carbonatação pelo método colorimétrico;

- Avaliação da profundidade de carbonatação em corpos-de-prova cilíndricos $(50 \times 100 \mathrm{~mm})$, nas idades de 90 e 180 dias, utilizando teores de CCCC entre $0 \%$ e $30 \%$;

h) Avaliação da capacidade de estabilização/solidificação da CCCC pela matriz cimentícia em pastas utilizando teores de CCCC entre 0\% e $10 \%$.

\subsection{Estrutura da dissertação}

A estrutura deste trabalho encontra-se dividida em seis capítulos. No primeiro apresentam-se a introdução, os objetivos e as justificativas deste trabalho.

No Capítulo 2 são abordadas questões sobre a valorização atual do uso de resíduos, sobre a necessidade de redução, reaproveitamento e reciclagem destes, sobre o aproveitamento de resíduos na Construção Civil, acerca das formas de gestão mais adequadas, sobre a metodologia para a reciclagem de resíduos e acerca da necessidade do esforço conjunto entre comunidade acadêmica, produtores e consumidores, para que se tenham melhores resultados, com impactos significativos nos setores econômicos, ambientais, sociais e técnicos. Após uma abordagem geral sobre o tema, são feitas considerações a respeito do uso de resíduos agroindustriais, acerca da relevância do uso específico das cinzas em materiais cimentícios e uma revisão sobre as cinzas de resíduos 
agroindustriais mais utilizadas atualmente como adição mineral em matrizes de cimento Portland. Com os dados obtidos na revisão bibliográfica, foi possível avaliar os resultados dos trabalhos disponíveis sobre o assunto pesquisado, analisar a posição de outros autores e criar uma linha de pensamento lógica e seqüenciada que auxiliou na elaboração da metodologia deste trabalho, utilizada para atingir os objetivos acima descritos.

No Capítulo 3 são discutidas algumas generalidades sobre o caju, a castanha de caju, e, mais especificamente, sobre o processo de obtenção da cinza da casca da castanha de caju. Alguns estudos realizados até o presente momento e as potencialidades de uso desse resíduo como adição mineral em matrizes cimentícias.

No capítulo 4 apresenta-se a caracterização dos materiais, bem como a metodologia empregada em todas as etapas deste trabalho.

O Capítulo 5 apresenta os resultados obtidos durante as análises experimentais, bem como as discussões pertinentes.

O Capítulo 6 contém as considerações finais e conclusões referentes à pesquisa, com sugestões para futuros estudos sobre cinzas agroindustriais, em especial, a cinza da casca da castanha de caju. 
Capítulo

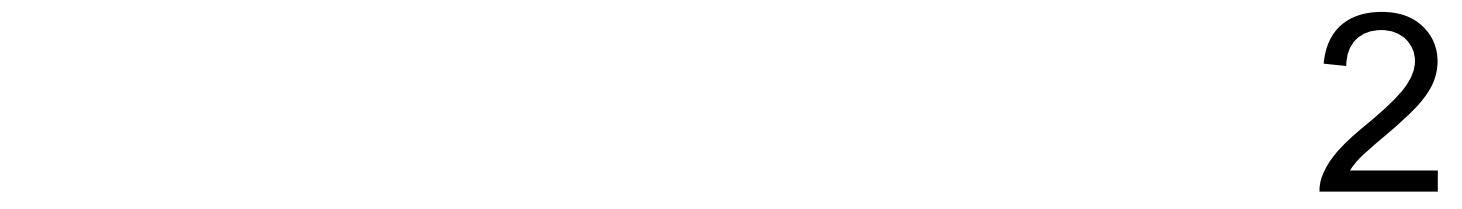

O USO DOS RESÍDUOS NA CONSTRUÇÃO CIVIL

Tudo que nos cerca um dia será resíduo: casas, automóveis, móveis, pontes, aviões, etc. A esse total, devemos somar todos os resíduos do processo de extração de matériasprimas e de produção dos bens. Assim, em qualquer sociedade, a quantidade de resíduos gerados supera a quantidade de bens consumidos. A sociedade industrial, ao multiplicar a produção de bens, agravou esse processo (ROCHA \& CHERIAF, 2003).

Ao termo "resíduos sólidos", em acordo com a norma NBR 10004 (ABNT, 2004), aplica-se a seguinte definição: "Resíduos nos estados sólido e semi-sólido, que resultam de atividades de origem industrial, doméstica, hospitalar, comercial, agrícola, de serviços e de varrição (...)".

As atividades especificamente relacionadas à indústria da Construção Civil possuem um enorme impacto ambiental, pois apresenta-se como o maior consumidor individual de recursos naturais. Estima-se que esse setor consuma entre $20 \%$ e $50 \%$ do total de recursos naturais utilizado pelas atividades industriais. Além disso, a atividade de construção também gera muitos resíduos sólidos. Segundo Pinto (1999), estima-se que a quantidade de entulho produzido no Brasil esteja em torno de 500 kg/hab.ano.

Adicionalmente, os processos de produção de materiais e componentes em geral consomem grandes quantidades de energia e eles são responsáveis também pela geração de grandes quantidades de $\mathrm{CO}_{2}$ e de partículas de poeira. Por outro lado, a Construção Civil mostra-se como potencial consumidora de resíduos provenientes de outras indústrias. Tal fato se deve a vários fatores, tais como a necessidade de redução do custo da construção, a elevada quantidade de matéria-prima consumida e a grande diversidade de produtos consumidos na produção, o que abre uma série de opções de uso de resíduos com diferentes funções na edificação (NOLASCO, 1993). 
De fato, o setor já se apresenta, atualmente, como um grande incorporador de alguns resíduos de outras indústrias, tais como a escória granulada de alto forno, a cinza volante e a sílica ativa. O destino mais comum dos resíduos no Brasil é a sua deposição em aterros sanitários. Isso gera muitos riscos de contaminação do solo e de mananciais de água, pois as possíveis medidas de proteção do meio ambiente nesses casos têm durabilidade limitada, além de resultar em custos de manutenção de aterros relativamente elevados (NEFUSSI, 1985).

Cabe acrescentar que a questão territorial também se apresenta como um problema importante para as grandes cidades. Aterros sanitários demandam espaços exclusivos para a deposição do lixo. Tal área poderia ser mais bem aproveitada para atividades de lazer ou para a construção de equipamentos comunitários de saúde ou educação.

A cidade de São Carlos, por exemplo, encontra-se, atualmente, com um problema dessa natureza. Devido ao grande volume de lixo gerado pelos habitantes, o aterro da cidade esgotou a capacidade de carga antes do previsto pelas autoridades municipais, não tendo sido providenciado à tempo um pedido de licitação para a construção de novas valas. Por esse motivo, a Prefeitura de São Carlos está tendo que pagar à uma cidade próxima para que seu lixo seja depositado no aterro desta cidade enquanto as medidas administrativas estiverem sendo tomadas.

Assim, a reciclagem de resíduos pode contribuir muito para a redução do impacto ambiental provocado pela Construção Civil. Além da diminuição da necessidade de extração de matérias-primas, da redução do consumo de energia, da minimização dos custos de transporte e da redução do volume de aterros, existe o potencial de obter materiais com características técnicas competitivas em relação aos produtos atuais.

Muitos dos materiais empregados na construção possuem composições e processos de produção relativamente simples, toleram certo grau de variabilidade e exigem resistências mecânicas relativamente baixas (SEMINÁRIO CIDADES, CIÊNCIA E TECNOLOGIA, 2003).

Também se pode reduzir o custo final da construção habitacional contribuindo para tornar as atividades industriais economicamente mais competitivas. Deve-se ressaltar, entretanto, que existe a necessidade de estudarem-se alternativas não somente para a 
reciclagem dos resíduos, mas também para a sua redução ${ }^{4}$. Segundo o conceito dos "3 R's" (Reduzir, Reutilizar e Reciclar), a redução na geração dos resíduos deve ser a primeira medida a ser tomada quando se trata da gestão dos resíduos.

Nefussi (1985) afirma que resíduos gerados em baixas quantidades limitam as opções comerciais da reciclagem que exige processamento industrial, e também que a sazonalidade da produção, típica da agroindústria, pode exigir a formação de estoques que permitam às unidades de reciclagem operar de maneira contínua. Tal prática já está sendo incorporada por algumas grandes indústrias, principalmente as que destinam seus produtos para exportação.

Paralelamente ao trabalho de mobilização da indústria sobre a questão da minimização da geração de resíduos, existe a necessidade de um esforço considerável de pesquisa nesse sentido, pois o desenvolvimento de novos materiais e componentes a partir de resíduos normalmente requer um período de investigação relativamente longo.

Uma opção no que se refere à redução de resíduos na construção pode ser encontrada com o aumento da durabilidade dos componentes. Produtos que tenham maior tempo de utilização contribuem diminuindo a substituição de componentes e/ou produtos durante a vida útil da habitação ${ }^{5}$. Um exemplo desse fato é a telha produzida com resíduos das embalagens longa vida (Figura 2.1). Mesmo tendo custo inferior aos das telhas de fibrocimento amianto, ainda não há estudos conclusivos acerca de sua vida útil. O Anexo $\mathrm{E}$ do Projeto de Norma 02:136.01.001/1 ${ }^{6}$ estipula uma vida útil mínima de 10 anos para os elementos e componentes dos sistemas de coberturas.

As formas mais usuais de aproveitamento de resíduos foram realizadas baseando-se apenas em aspectos qualitativos, sem investigações mais amplas que justificassem a avaliação do comportamento a longo prazo. Tal método, analisado por este trabalho como insuficiente, pode ter sido a causa principal de danos ao meio ambiente, expondo a edificação e seus usuários a riscos de contaminação pelos resíduos.

\footnotetext{
${ }^{4}$ Id., 2003, p. 207.

${ }^{5}$ SEMINÁRIO CIDADES, CIÊNCIA E TECNOLOGIA, 2003, passim.

${ }^{6}$ ABNT (2006). Projeto 02:136.01-001/1. Edifícios habitacionais de até cinco pavimentos - Desempenho Parte 1: Requisitos gerais. Versão: 15 Maio 2006.
} 


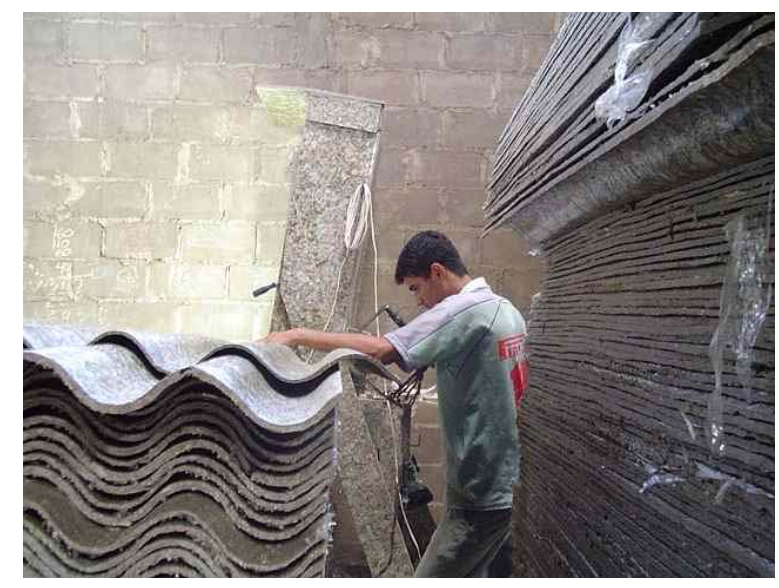

Figura 2.1 - Fabricação da telha produzida com resíduos das embalagens longa vida. Fonte: Lima, 2003.

As formas adequadas de aproveitamento de resíduos, ou de subprodutos industriais, como matéria-prima secundária, devem envolver um completo conhecimento do processo: as unidades de geração, a caracterização completa dos resíduos e a identificação do potencial de aproveitamento (ROCHA \& CHERIAF, 2003).

John (2000) sugere uma seqüência de passos no sentido de aumentar a eficácia da pesquisa nessa área: a) identificação e quantificação dos resíduos; b) seleção do resíduo a ser investigado; c) detalhamento dos dados estatísticos; d) apropriação dos custos associados aos resíduos; e) compreensão do processo gerador do resíduo; f) caracterização do resíduo; g) seleção das aplicações a serem desenvolvidas; $h$ ) desenvolvimento do produto; i) avaliação do produto; j) análise do desempenho ambiental; k) análise de viabilidade econômica; I) transferência de tecnologia.

Sabe-se, contudo, que diante das várias etapas a serem seguidas na gestão de um resíduo (principalmente subprodutos ainda desconhecidos quanto ao seu aproveitamento na construção civil) cabe a iniciativa individual do pesquisador. Esse deve apoiar sua escolha em análises críticas que o auxiliem na escolha de um foco a ser explorado em primeira instância. Sendo assim, a análise pode ter início pela viabilidade técnica, econômica, ambiental e/ou social do subproduto, já que as demais etapas podem e devem ser tomadas posteriormente, sem prejuízo para o andamento da pesquisa.

Em uma dessas possibilidades quanto ao início das investigações, pode-se dar ênfase à viabilidade técnica do produto. Com base em revisão bibliográfica pertinente sobre os materiais semelhantes ao novo subproduto, obtêm-se diversas opções para melhor direcionar as futuras análises. Dessa forma, contribui-se na ampliação do campo de atuação do pesquisador, colaborando para o início da investigação. Esse processo de "afunilamento" 
das possibilidades e as tomadas de decisão seqüenciadas se apresentam durante todo processo de análise. Uma decisão equivocada, ou mal dimensionada no início, pode mudar o rumo de toda a pesquisa subseqüente.

Uma possibilidade da análise da viabilidade de um novo material para a construção civil, proposto por esta pesquisa, tomando por base outras metodologias (JOHN, 2000; JOHN \& ÂNGULO, 2003) encontra-se na Figura 2.2. O caminho percorrido, focando-se primeiramente na viabilidade técnica do material, é optativo e foi escolhido por esta pesquisa como ponto de partida. Como dito anteriormente, essa tomada de decisão preliminar cabe ao pesquisador, baseando-se na sua área de atuação, na problematização levantada durante a revisão bibliográfica e em outras variáveis que esse julgar importantes.

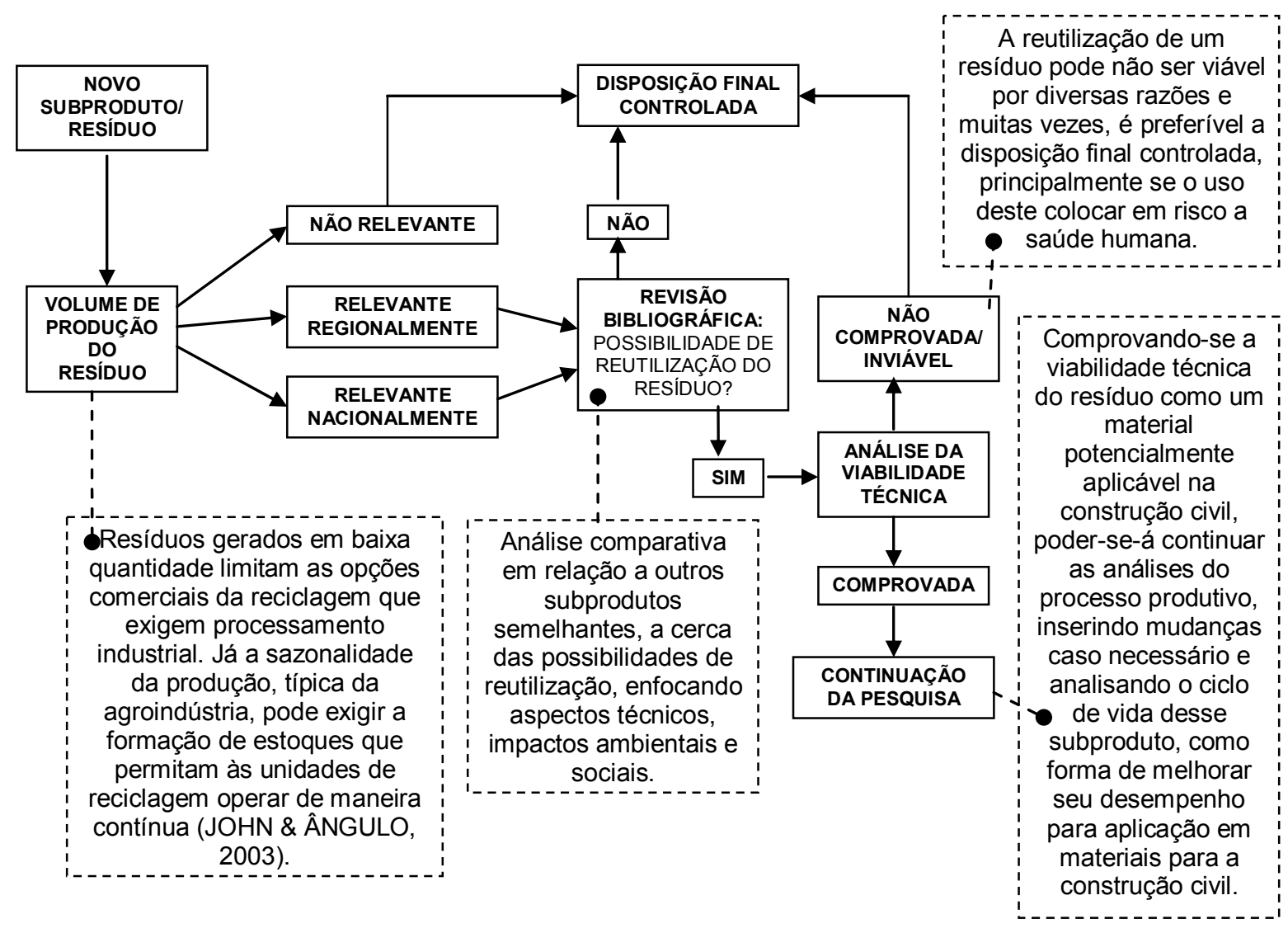

Figura 2.2 - Esquema simplificado do processo de análise de desempenho com ênfase na viabilidade técnica proposto e utilizado por esta pesquisa

Para John \& Ângulo (2003), o processo de análise de um novo subproduto deve ter um caráter multidisciplinar, integrando conhecimentos de áreas do conhecimento bastante diversas, incluindo biologia, química, engenharia de materiais e marketing, entre outros. 
Os mesmo autores analisam que as pesquisas de reciclagem de resíduos se limitam a aspectos do desenvolvimento técnico do material e, felizmente de forma mais freqüente, a analisar os impactos ambientais do processo. Entretanto, para os autores, a ênfase em viabilidade do mercado deve ser um compromisso aliado com a eficácia da pesquisa, pois os benefícios sociais de um processo de pesquisa somente vão se realizar na sua totalidade se o novo produto produzido gerar empregos, reduzir o volume de aterros, consumir resíduos no lugar de recursos naturais e evitar a contaminação do ambiente ou o comprometimento da saúde da população. A viabilidade em um determinado mercado depende da viabilidade econômica do processo, da estratégia de marketing adotada, da adequação do produto às restrições legais locais e de sua aceitação pela sociedade. Assim, o desenvolvimento de investigação no domínio de ciências dos materiais e ambientais é fundamental, mas não suficiente.

Portanto, os conhecimentos relativos à viabilidade técnica de um material não devem ser, de forma alguma, creditados como único e principal método de avaliação de novos resíduos. Contudo, tal estratégia pode apresentar-se como o início de uma análise continuada e ampla, que possa envolver outros aspectos relevantes de viabilidade da aplicação do resíduo.

Mostra-se essencial que o esforço de pesquisa e desenvolvimento envolva o trabalho conjunto da comunidade acadêmica com empresas produtoras e consumidoras dos resíduos - a falta de envolvimento dessas empresas tem sido uma das principais dificuldades enfrentadas em algumas pesquisas desenvolvidas no país.

Como regra geral, toma-se que as aplicações possíveis são aquelas que melhor aproveitam as características fisico-químicas que o resíduo apresenta, como um todo ou nas suas diferentes fases. Tais aspectos são importantes para gerar um novo produto de melhor desempenho e menor impacto ambiental, em relação às soluções tradicionais, com condições de competir em um nicho específico de mercado. De acordo com a necessidade, existe uma grande tradição na engenharia em buscar uma matéria-prima que atenda a tal precisão. No caso dos resíduos, o caminho é inverso: dispõe-se de um produto e buscam-se nichos de mercado que eles possam atender (JOHN \& ÂNGULO, 2003).

No item seguinte analisa-se o uso dos resíduos agroindustriais, sua possível utilização em produtos para a construção civil e, mais especificamente, o uso das cinzas (produto da incineração dos resíduos), sua classificação e a potencial aplicabilidade dessas em matrizes de cimento Portland como adições minerais. 


\subsection{0 uso de resíduos agroindustriais}

Todo processo industrial ou agroindustrial tem como objetivo a geração de um produto rentável para determinado grupo ou empresa. Entretanto, para Nefussi (1985), há, necessariamente, a geração de resíduos, tendo em vista que quase todos esses processos de produção são falíveis. $O$ autor ainda salienta que muitos resíduos representam ônus para seus geradores, como as grandes indústrias de processamento, principalmente por conta de custos com transporte, estocagem, tratamento e/ou disposição final dos mesmos.

Os resíduos industriais e agroindustriais comuns são importantes fontes de matériasprimas, o problema reside na pesquisa e na adequação desses materiais entre os produtos propostos e os produtos utilizados pelas indústrias, considerando ainda que essa transferência deva ser feita em acordo com condições econômicas aceitáveis (NEFUSSI, 1985).

A reciclagem desses resíduos apresenta-se hoje como uma oportunidade para a preservação do meio ambiente e para a redução do custo e do consumo de energia na produção de materiais e componentes de construção. Silva \& Souza (1995) afirmam que a construção civil, pelo expressivo volume físico de materiais que incorpora, é o mercado mais propício para reciclagem de novos resíduos.

Segundo Cincotto (1988), a potencial utilização de resíduos agroindustriais na obtenção de novos materiais para a construção civil se deve basicamente a: i) necessidade de redução do custo da construção; ii) elevada quantidade de matéria prima de recursos naturais que é consumida; iii) preocupação com o esgotamento dessas reservas naturais.

Cabe salientar que alguns tratamentos, visando a reutilização, já estão sendo empregados em resíduos agroindustriais, como a incineração (utilização como combustível); no entanto, esses processos geram outros subprodutos (pós, cinzas, lodos e escória), obrigando os produtores a descartarem esses últimos resíduos em aterros ou locais não apropriados para sua disposição.

Aplicações de resíduos agroindustriais como adição mineral no cimento Portland tem grande aplicabilidade na construção civil, visto que esses materiais possuem características físicas e químicas que são próprias para utilização em concretos e argamassas (MANNAN \& GANAPATHY, 2004). 
As cinzas são resíduos gerados por processos agroindustriais, ou se originam da queima de outros resíduos, devido a reincorporação desses no processo. Pode ser citado como exemplo a casca do arroz, resíduo incinerado para obtenção de energia e que gera a cinza da casca do arroz, um outro subproduto com alta pozolanicidade.

As cinzas ocupam lugar de destaque dentre os resíduos agroindustriais por resultarem de vários processos de geração de energia e de secagem e também apresentam problemas de armazenamento e impacto ambiental (CINCOTTO, 1988).

Em princípio, qualquer cinza vegetal predominantemente siliciosa, que possa ser produzida no estado amorfo e com finura adequada, pode ser utilizada como adição mineral. Sua reatividade vai depender da composição química, fortemente influenciada pelo produto que gerou a cinza, pelo solo e pelo processo de produção da cinza. Uma vez que contenham elevado teor de sílica amorfa podem ser de utilização viável como adições minerais (JOHN et al., 2003).

Outro fator relevante referente às adições minerais deve-se à sua composição física (estado amorfo ou cristalino) e, caso apresentem reatividade em meio aquoso com o $\mathrm{CH}$ (hidróxido de cálcio), resultando em endurecimento, podem ser utilizados como adição mineral pozolânica (JOHN et al., 2003).

A reação pozolânica se caracteriza pelo consumo lento do $\mathrm{CH}$ livre, após hidratação do cimento anidro, pelo material pozolânico gerando C-S-H (silicato de cálcio hidratado) adicional, segundo demonstra a Figura 2.3. Essa reação pode ser simplificadamente representada pela Equação 01.

$$
\alpha \mathrm{SiO}_{2}+\beta \mathrm{CaO}+\varphi \mathrm{H}_{2} \mathrm{O} \rightarrow \alpha \mathrm{CaO} \cdot \beta \mathrm{SiO}_{2} \cdot \varphi \mathrm{H}_{2} \mathrm{O}
$$

As pozolanas, sejam elas naturais ou artificiais, devem ter como constituinte preponderante a sílica, que reage com a cal para formar o $\mathrm{C}-\mathrm{S}-\mathrm{H}$, contribuindo para a resistência mecânica do sistema cimentício. Pode conter também alumina e óxido de ferro responsáveis pela formação de sílico-aluminatos e aluminatos, com contribuição menos expressiva para a resistência mecânica, além de óxidos de metais alcalinos e óxido de cálcio (CINCOTTO, 2007). 


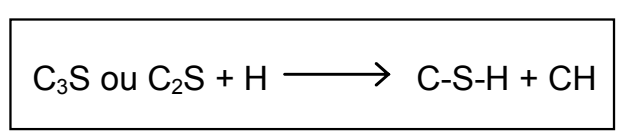

CIMENTO PORTLAND

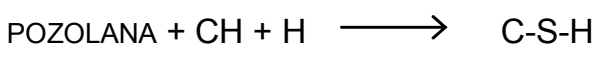

CIMENTO PORTLAND COM POZOLANA

SIGLAS

$\mathrm{H}$ : água;

$\mathrm{C}_{2} \mathrm{~S}$ : silicato dicálcico;

$\mathrm{C}_{3} \mathrm{~S}$ : silicato tricálcico;

$\mathrm{CH}$ : hidróxido de cálcio;

C-S-H : silicato de cálcio hidratado

Figura 2.3 - Mecanismos da ação pozolânica. Fonte: MEHTA \& MONTEIRO, 1994.

Os materiais pozolânicos liberam os metais alcalinos, quando presentes em sua constituição, em decorrência da reação pozolânica. Em concretos nos quais o teor de álcalis deve ser baixo, como, por exemplo, em concretos massa e concretos com agregado reativo, o seu teor deve ser conhecido e levado em conta no teor limite de álcalis permitido. Esse limite é fixado em função da contribuição de cada constituinte da mistura: cimento, água, aditivo e pozolana.

A identificação da presença da fase vítrea pode ser feita por análise por difração de raios $\mathrm{X}$. O difratograma apresenta, juntamente com picos característicos de fases cristalinas, um halo de amorfismo cujo ponto máximo está situado em um ângulo $2 \theta$ característico para cada material.

A finura pode ser grosseiramente estimada pela fração retida na peneira \#200, de abertura de malha $0,075 \mathrm{~mm}$.

Outros métodos são a granulometria a laser e área específica por adsorção de nitrogênio (método BET). A área específica, determinada segundo o método Blaine, apresenta-se inadequada para caracterizar uma pozolana em virtude da sua porosidade e também por não ser sensível para a determinação de áreas específicas elevadas.

Quanto à contribuição da finura para a reatividade tem-se que: i) a área específica $\left(\mathrm{m}^{2} / \mathrm{g}\right)$ cresce na razão inversa da diminuição do diâmetro; ii) partículas menores resfriaramse mais rapidamente e, conseqüentemente, apresentam maiores teores de vidro; iii) no caso de pozolanas produzidas pela combustão de vegetais onde a sílica é originalmente amorfa, a elevação da temperatura próxima a pontos de fusão provoca a aglomeração de partículas e recristalização da sílica. Outro critério é o de que a quase totalidade das partículas das 
pozolanas encontrem-se abaixo da peneira $0,035 \mathrm{~mm}$. Outras características são dadas na Tabela 2.1.

Tabela 2.1 - Características físicas de diversos materiais

\begin{tabular}{ccccc}
\hline Características & Cimento & $\begin{array}{c}\text { Cinza } \\
\text { volante }\end{array}$ & $\begin{array}{c}\text { Cinza de casca } \\
\text { do arroz }\end{array}$ & $\begin{array}{c}\text { Filer } \\
\text { calcário }\end{array}$ \\
\hline Massa específica $\left(\mathrm{kg} / \mathrm{dm}^{3}\right)$ & 3,12 & 2,36 & 2,02 & 2,33 \\
\hline Área específica BET $\left(\mathrm{m}^{2} / \mathrm{kg}\right)$ & 1,8 & 3,6 & 40,1 & 5,3 \\
\hline$\Phi$ médio dos grãos $(\mu \mathrm{m})$ & 8,3 & 9,1 & 10,8 & 3,6 \\
\hline$\Phi<3 \mu \mathrm{m}(\%)$ & 25,9 & 19,1 & 12,7 & 45,8 \\
\hline
\end{tabular}

Fonte: Cincotto $(2007)^{7}$

Os materiais pozolânicos são definidos pela norma NBR 12653 (ABNT, 1992) como "materiais silicosos ou silicoaluminosos que, por si sós, possuem pouca ou nenhuma atividade aglomerante, mas que, quando finamente divididos e na presença da água, reagem com o hidróxido de cálcio à temperatura ambiente para formar compostos com propriedades aglomerantes". Essa classificação possui a seguinte subdivisão:

- Pozolanas naturais - Materiais de origem vulcânica, geralmente de caráter petrográfico ácido (mais que $65 \%$ de $\mathrm{SiO}_{2}$ ) ou de origem sedimentar com atividade pozolânica.

- Pozolanas artificiais - Materiais provenientes de tratamento térmico ou subprodutos industriais com atividade pozolânica.

- Argilas calcinadas - Materiais provenientes de calcinação de certas argilas submetidas a temperaturas, em geral, entre $500^{\circ} \mathrm{C}$ e $900^{\circ} \mathrm{C}$, de modo a garantir a sua reatividade com hidróxido de cálcio.

- Cinzas volantes - Resíduos finamente divididos que resultam da combustão de carvão mineral pulverizado ou granulado com atividade pozolânica (Figura 2.4).

- Outros materiais - Materiais não-tradicionais, tais como: escórias siderúrgicas ácidas, cinzas de resíduos vegetais e rejeito de carvão mineral.

\footnotetext{
${ }^{7}$ Cincotto, M. A. (2007) Materiais pozolânicos. Nota de aula da disciplina "Aglomerantes de argamassas e concretos". PCC/EPUSP.
} 


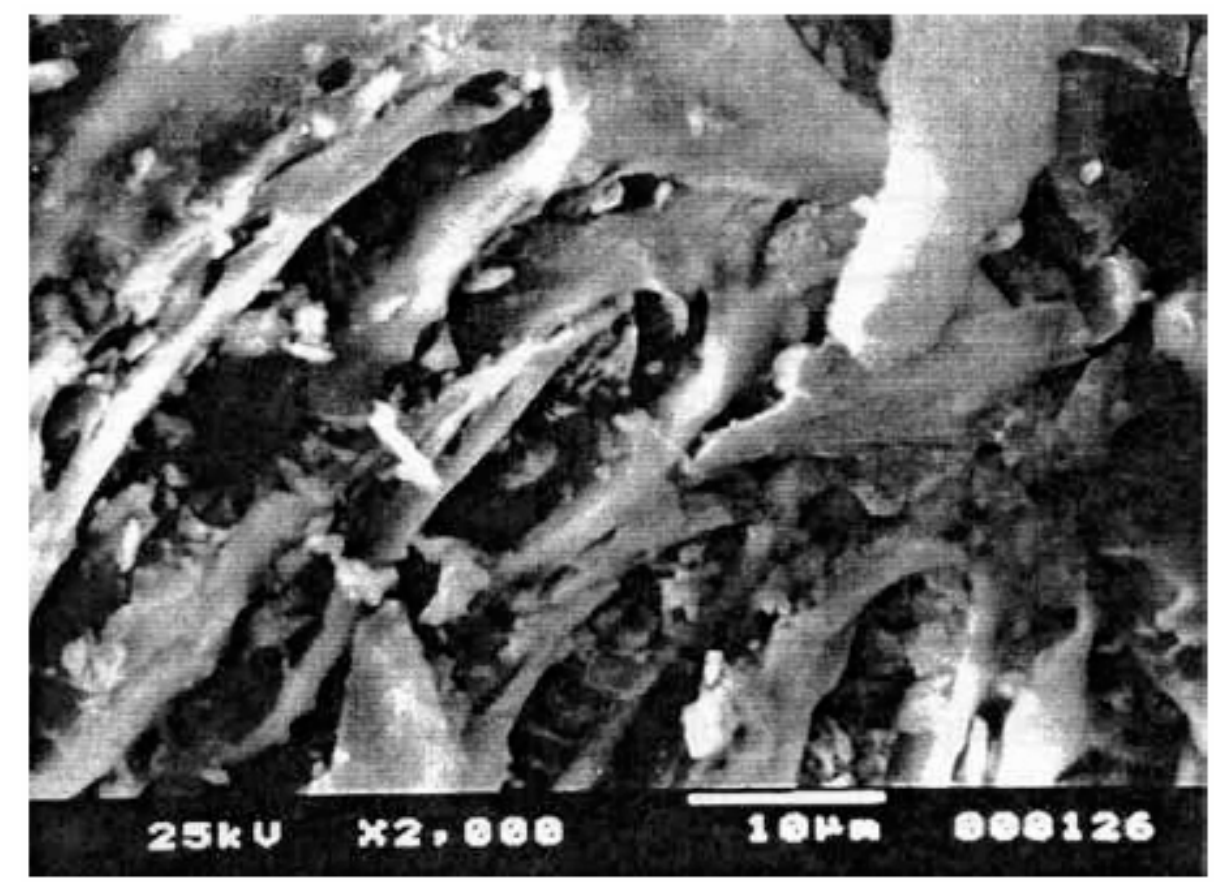

Figura 2.4 - Micrografia eletrônica de varredura da cinza de casca de arroz queimada a $560^{\circ} \mathrm{C}$. Fonte: Silveira e Ruaro, 1995 apud Prudêncio Jr. et al., 2003.

A NBR 12653 (ABNT, 1992) também classifica esses materiais em 3 (três) classes, a saber:

- Classe $N$ - Pozolanas naturais e artificiais que obedeçam aos requisitos aplicáveis pela NBR 12653/92;

- Classe C - Cinza volante produzida pela queima de carvão mineral em usinas termoelétricas, que obedece aos aos requisitos aplicáveis pela NBR 12653/92;

- Classe E - Qualquer pozolana cujos requisitos diferem das classes anteriores, conforme estabelecido nesta Norma. Nota: Alguns materiais que se enquadram nesta classe podem apresentar propriedades aglomerantes.

Esta divisão em classes é baseada nos valores mínimos dos componentes químicos dos materiais pozolânicos, conforme indicados na Tabela 2.2.

Para Mehta \& Monteiro (1994), as "adições minerais" são "materiais silicosos finamente moídos, adicionados ao concreto em quantidades relativamente grandes, geralmente na faixa de 20 a 100\% da massa de cimento Portland". Os autores afirmam também que embora as pozolanas naturais sejam empregadas amplamente, muitos 
subprodutos estão se tornando uma fonte promissora de adições minerais para produtos cimentícios.

Tabela 2.2 - Exigências químicas e físicas dos materiais pozolânicos.

\begin{tabular}{lccc}
\hline \multicolumn{1}{c}{ Propriedades } & \multicolumn{3}{c}{ Classe de material } \\
\cline { 2 - 4 } & $\mathbf{N}$ & $\mathbf{C}$ & $\mathbf{E}$ \\
\hline $\mathrm{SiO}_{2}+\mathrm{Al}_{2} \mathrm{O}_{3}+\mathrm{CaO}, \%$ mín. & 70,0 & 70,0 & 50,0 \\
\hline $\mathrm{SO}_{3}, \%$ máx. & 4,0 & 4,0 & 5,0 \\
\hline teor de umidade, \% máx. & 3,0 & 3,0 & 3,0 \\
\hline perda ao fogo, \% máx. & 10,0 & 6,0 & 6,0 \\
\hline álcalis disponíveis em $\mathrm{Na}_{2} \mathrm{O}, \%$ máx. & 1,5 & 1,5 & 1,5 \\
\hline material retido na \#325 & 34,0 & 34,0 & 34,0 \\
\hline índice de atividade pozolânica: & & & \\
\hline com o cimento aos 28 dias, \% mín. (NBR 5752) & 75,0 & 75,0 & 75,0 \\
\hline com a cal aos 7 dias, MPa. (NBR 5751) & 6,0 & 6,0 & 6,0 \\
\hline água requerida, \% máx. & 1,5 & 1,5 & 1,5 \\
\hline
\end{tabular}

Fonte: NBR 12653/92

Para Lohtia \& Joshi (1995), o termo "adição mineral" se refere aos "materiais finamente divididos que são adicionados aos materiais cimentícios para melhorar algumas características específicas".

Algumas adições minerais podem ser classificadas como cimentantes ou como pozolânicas, enquanto outras podem ser tanto cimentantes quanto pozolânicos, quanto ao seu mecanismo de ação (MEHTA \& MONTEIRO, 1994). Qualquer uma dessas adições, independente da origem, podem vir a necessitar de um processamento adicional (por exemplo, britagem ou moagem) para se adequarem como materiais pozolânicos para uso em matrizes cimentícias. As adições minerais ditas cimentantes não necessitam do $\mathrm{CH}$ presente no cimento Portland para formar C-S-H. No entanto, sua auto-hidratação apresenta-se normalmente lenta e os produtos cimentantes formados são insuficientes para utilização do material com fins estruturais.

Apesar de ser um ponto de partida para classificar as adições minerais como materiais pozolânicos ou não, Malhotra \& Mehta (1996) criticam algumas normas, como a NBR 12653/92, por várias razões: i) a quantidade mínima de $70 \%$ de $\left(\mathrm{SiO}_{2}+\mathrm{Al}_{2} \mathrm{O}_{3}+\mathrm{Fe}_{2} \mathrm{O}_{3}\right)$ não apresenta relação direta com as propriedades do material; ii) parte-se do princípio de que o material encontra-se na fase amorfa, o que muitas vezes não ocorre; iii) além disso não 
estão contemplados os materiais cimentantes ou cimentantes/pozolânicos, desconsiderando o efeito benéfico proporcionado pela existência de maiores teores de óxido de cálcio $(\mathrm{CaO})$.

Neste trabalho dá-se ênfase às adições minerais artificiais e pozolânicas, uma vez que as cinzas vegetais podem se enquadrar na Classe de Material Pozolânico "E", segundo a NBR 12653 (ABNT, 1992).

O uso de adições minerais na construção civil antecede a invenção do cimento Portland, tendo iniciado, conforme Malhotra \& Mehta (1996), no período de 1500a.C., na Grécia. Atualmente as adições minerais mais comumente usadas são resíduos provenientes de outras indústrias, os quais seriam normalmente descartados em grandes quantidades em locais impróprios, gerando o risco de contaminação do solo e da água (DAL MOLIN, 2005).

Encontra-se na literatura atual muitas pesquisas que estão sendo desenvolvidas com resíduos agroindustriais visando seu aproveitamento como adições minerais em matrizes cimentícias.

Investigações de Cincotto \& Kaupatez (1988) demonstraram que a cinza do bagaço da cana-de-açúcar requer ainda mais estudos e que as cascas de amendoim e de mamona não apresentam potencial pozolânico. Tay \& Show (1996) por sua vez, investigaram cinzas da casca do coco da produção de dendê e do cacho da mesma planta. Adesanya (1996) estudou cinzas de sabugo de milho. Experimentos não publicados dos pesquisadores Vanderley Moacir John e Maria Alba Cincotto, da Escola Politécnica da USP, demonstram potencial aglomerante das cinzas de capim colonião (JOHN et al., 2003).

A Tabela 2.3 apresenta a comparação entre as características físicas e a atividade pozolânica (consumo de $\mathrm{CaO}$ ) de algumas das cinzas vegetais estudadas até o presente momento.

Quando se trata de implicações ambientais, o uso de cinzas de origem agrícola utilizadas como componente de substituição parcial do cimento Portland resulta numa economia significativa de energia e custo (MEHTA \& MONTEIRO, 1994). 
Tabela 2.3 - Características físicas e atividade pozolânica de algumas cinzas vegetais.

\begin{tabular}{cccc}
\hline Cinza & $\begin{array}{c}\text { Massa específica } \\
\left(\mathbf{g} / \mathbf{c m}^{\mathbf{3}}\right)\end{array}$ & $\begin{array}{c}\text { Área específica } \\
\text { Blaine } \mathbf{( \mathbf { c m } ^ { 2 } / \mathbf { g } )}\end{array}$ & $\begin{array}{c}\text { Atividade pozolânica - } \\
\text { Consumo de CaO }\end{array}$ \\
\hline Casca de arroz & 2,11 & 10.238 & 770 \\
\hline Bagaço de cana & 2,07 & 19.385 & 300 \\
\hline Casca de amendoim & 2,18 & 5.055 & 340 \\
\hline Casca da mamona & 2,26 & 4.145 & 240 \\
\hline
\end{tabular}

Fonte: John et al., 2003.

Ao ser dispensada a calcinação de uma parte do aglomerante e, algumas vezes, até mesmo eliminando ou reduzindo a moagem, diminui-se consideravelmente o consumo de energia associado à produção dos aglomerantes.

Neville (1992) afirma que o cimento Portland é um material de custo elevado que depende de alto consumo de energia e matérias-primas e que, no futuro, devem ser empregados cada vez mais materiais alternativos que possam produzir concretos mais econômicos e com melhor desempenho.

Sabe-se que para produzir uma tonelada de cimento Portland, por exemplo, são emitidos aproximadamente uma tonelada de dióxido de carbono $\left(\mathrm{CO}_{2}\right)$ na atmosfera $(\mathrm{JOHN}$, 2000). No Brasil, segundo o mesmo autor, a indústria cimenteira representa $6 \%$ das emissões de $\mathrm{CO}_{2}$. Dessa forma, o uso de adições minerais na indústria do cimento, substituindo parcialmente o clínquer ou cimento, não só pode contribuir na diminuição dos impactos ambientais causados pelos resíduos quando jogados em depósitos sem destino adequado, como também pode reduzir o volume de extração de matérias-primas por parte da indústria da construção civil (DAL MOLIN, 2005).

Não menos importante é o fato de que a utilização de resíduos, particularmente as cinzas, permite alterar as características dos aglomerantes, especialmente do cimento Portland, tornando possível a melhoria de seu desempenho em aplicações específicas (JOHN et al., 2003).

A presença de altos teores de sílica nas cinzas agroindustriais (de origem vegetal), em alguns casos com elevado índice de pozolanicidade (reatividade com o hidróxido de cálcio presente no cimento e na cal) pode viabilizar a utilização desses produtos como adições minerais em materiais cimentícios, como concretos e argamassas (MEHTA \& MONTEIRO, 1994). 
No item seguinte são comentados os estudos encontrados na literatura científica, nacional e internacional, de algumas das principais cinzas vegetais, bem como os resultados obtidos mais relevantes, atestando-se a viabilidade do uso desses resíduos em materiais cimentícios.

\subsection{As cinzas agroindustriais utilizadas em matrizes de cimento Portland}

Nesta etapa são apresentadas as principais cinzas agroindustriais utilizadas em matrizes cimentícias, cujas análises e os resultados obtidos serviram de embasamento experimental para esta pesquisa.

\subsubsection{Cinza da casca do arroz}

O resíduo agroindustrial mais estudado, atualmente, como adição mineral em materiais cimentícios é a cinza da casca de arroz (CCA), obtida da queima das cascas do arroz. Esse resíduo é estudado por grande parte dos pesquisadores que se ocupam da avaliação sobre o potencial aglomerante das cinzas vegetais.

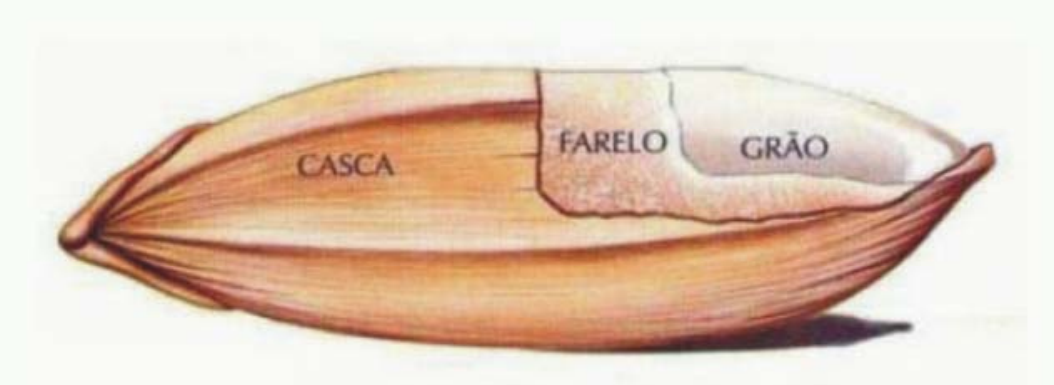

Figura 2.5 - Estrutura do grão de arroz. Fonte: <http://www.josapar.com.br>

A casca de arroz é uma capa lenhosa do grão, dura, com alto teor de sílica, composta de aproximadamente $50 \%$ de celulose, $30 \%$ de lignina e $20 \%$ de sílica de base anidra (MEHTA, 1992). Quando queimada, a lignina e a celulose podem ser removidas, resultando uma estrutura celular e porosa. 
A palha de arroz tem um alto teor de sílica e, com um tratamento a uma temperatura adequada, pode resultar num material amorfo com estrutura porosa e área específica de até $50.000 \mathrm{~m}^{2} / \mathrm{kg}$, mesmo com partículas relativamente grandes, entre $10 \mu \mathrm{m}$ e $75 \mu \mathrm{m}$ (NEVILLE, 1997).

Quanto à origem do arroz, vários autores apontam como sendo o continente asiático, sendo o Brasil o primeiro país a cultivar esse cereal no continente americano (SANTOS, 1997; NEHDI et al. 2003; e outros). A prática da orizicultura no Brasil, de forma organizada e racional, aconteceu em meados do século XVIII e, daquela época até metade do século XIX, o Brasil foi um país exportador de arroz (ROSA, $2005^{8}$ apud DI CAMPOS, 2005).

A produção mundial de arroz em casca, no ano de 2004, foi da ordem de 591,2 milhões de toneladas, sendo a China a maior produtora mundial, seguida pela Índia, Indonésia e Bangladesh (WORLD RICE PRODUCTION, 2005).

No Brasil, a produção de arroz é da ordem de 12 milhões de toneladas por ano ((ROSA, $2005^{9}$ apud DI CAMPOS, 2005), levando a uma disponibilidade de 480.000 toneladas anuais ${ }^{10}$ de cinza.

A casca do arroz é bastante atrativa como fonte de energia renovável por possuir metade do poder calorífico do carvão (MALHOTRA \& MEHTA, 1996). A casca do arroz obtida do processo de beneficiamento do arroz é um resíduo que possui alto poder calorífico e custo praticamente nulo, que vem substituindo, cada vez mais, a lenha empregada na geração de calor e vapor, necessários para os processos de secagem e parboilização dos grãos (CINCOTTO et al.,1990).

Atualmente, são as empresas beneficiadoras de arroz as principais consumidoras da casca como combustível para a secagem e parboilização do cereal. Como se trata, geralmente, de empresas de pequeno porte, não possuem processos para aproveitamento e descarte adequados das cinzas produzidas. Essas são geralmente depositadas em terrenos baldios ou lançadas em cursos d'água, ocasionando poluição e contaminação de mananciais.

\footnotetext{
${ }^{8}$ ROSA, G. R. (2005). Anuário Brasileiro de Arroz 2005. Santa Cruz do Sul : Ed. Gazeta Santa Cruz, 136p.

${ }^{9}$ Idem.

${ }^{10}$ Cálculos feitos por esta pesquisa, segundo o trabalho de Cincotto \& Kaupatez (1988).
} 
Para minimizar o problema, órgãos ambientais têm buscado regulamentar o descarte dessas cinzas. No estado de Santa Catarina, por exemplo, a Fundação de Amparo à Tecnologia do Meio Ambiente (FATMA) exige a instalação de um sistema constituído de silo separador e decantação para reter a cinza junto às beneficiadoras, evitando, dessa forma, que o resíduo seja lançado no meio ambiente. Como não há emprego para a cinza recolhida, esse material estocado acaba sendo lançado de forma clandestina no meio ambiente, muitas vezes ao longo de estradas vicinais (PRUDÊNCIO Jr et al., 2003).

Até a década de 1970, a cinza da casca de arroz era utilizada na produção de blocos de concreto e o primeiro trabalho científico publicado, que investigava o potencial aglomerante dessas cinzas, foi registrado em 1973 (MEHTA, 1992).

A utilização da cinza de casca de arroz (CCA) como material pozolânico vem sendo intensamente investigada desde a década de 70, principalmente na Índia e nos EUA. Somente a partir da década de 1980, com o desenvolvimento da tecnologia do concreto de alto desempenho, a preocupação de aumentar a pozolanicidade do material se tornou premente (MEHTA, 1992).

No Brasil, a maior parte dos trabalhos sobre o uso de cinzas de casca de arroz como material pozolânico foi realizada com cinzas residuais provenientes da queima da casca em beneficiadoras dos cereais. Em alguns casos, quando as beneficiadoras possuíam queimadores de leito fluidizado, a temperatura de queima era controlada para evitar a formação de sílica cristalina. Nos demais, os estudos foram realizados com cinzas obtidas de queimas sem um controle efetivo do tempo e da temperatura de queima. De um modo geral, os resultados obtidos nas pesquisas brasileiras concluíram que a cinza de casca de arroz é uma excelente pozolana, com desempenho comparável ao da sílica ativa (PRUDÊNCIO Jr et al., 2003).

Souza \& Libório (1999) obtiveram êxito na extração da sílica ativa contida na casca do arroz e, posteriormente, registraram patente ${ }^{11}$ sobre o processo de extração da sílica contida na casca do arroz e em outras partes, como na folha e no caule, ou em qualquer outra planta.

\footnotetext{
${ }^{11}$ SOUZA, M. F.; LIBÓRIO, J. B. L.; BATISTA, P. S. (1999). Processo de extração da sílica contida na casca e na planta do arroz. Patente: Privilégio de Inovação. n. PI9903208. 30 jun. 1999 (Depósito), São Carlos.
} 
Desde que seja processada adequadamente, a CCA pode se tornar mais reativa com o cimento Portland que a cinza volante, mesmo sabendo-se que a temperatura na qual a casca do arroz é queimada modifica a estrutura dos seus compostos, transformando gradualmente a sílica do estado amorfo para o estado cristalino. A sílica cristalina pode ser ofensiva à saúde humana, tendo que ser mantida na forma amorfa por meio de queima controlada (MALHOTRA \& MEHTA, 1996).

Chandra (1996) sugere que essa temperatura não ultrapasse $800^{\circ} \mathrm{C}$ ao longo de 1 (uma) hora, porém, outros autores (SANTOS, 1997; SANTOS \& PRUDÊNCIO Jr, 1998; RÊGO et al., 2004) sugerem variações nessa temperatura, salientando que a mesma não deve ultrapassar $700^{\circ} \mathrm{C}$. Estudos realizados na Universidade da Califórnia (MEHTA, 1992) indicam que a temperatura de queima da casca de arroz para que a sílica se mantenha na fase amorfa, situa-se entre $500^{\circ}$ e $700^{\circ} \mathrm{C}$.

Rêgo et al. (2004) obtiveram valores consideráveis de resistência à compressão utilizando CCA cristalina, enquanto Santos \& Prudêncio Jr. (1998) alcançaram uma melhora significativa na pozolanicidade da cinza à medida que se aumentou o tempo de moagem, diminuindo progressivamente a granulometria da CCA.

Focando em produtos específicos, Da Fonseca (1993) estudou a cinza da casca de arroz para estabilização de solos na fabricação de tijolos. Geyer et al. (1993) estudaram a possibilidade de se utilizar um concreto leve em que a casca de arroz é o agregado. Mesmo não sendo aplicada na forma de cinza, o resíduo do arroz encontrou um novo nicho de aplicação, ainda que o autor esclareça que o concreto fabricado com agregado de casca de arroz tenha apresentado problemas relacionados ao aumento no consumo de cimento.

Estudos realizados com a cinza da casca de arroz aplicada em matrizes de cimento Portland demonstraram ganho de desempenho, em relação à sílica ativa, aos 3 dias de idade. A cinza da casca de arroz é um material potencialmente reativo, utilizada como pozolana artificial, que contém teor considerável de $\mathrm{SiO}_{2}$ (acima de 90\%), no qual a reatividade depende de dois fatores: a cristalinidade e a área específica (ODA \& LIBÓRIO, 2002).

O estudo do comportamento de duas cinzas residuais obtidas por queimas não controladas, realizado por Prudêncio Jr et al. (2003), resultou em desempenhos similares aos da sílica ativa, que é, reconhecidamente, uma pozolana de alta reatividade. 
Santos (1997) também constatou que o grau de moagem da cinza de casca de arroz (CCA) influencia significativamente o seu desempenho, medido pelo índice de atividade pozolânica. Pela Figura 2.6 pode-se notar que, a partir de uma dada finura, o índice de pozolanicidade tende a cair, fato este que, provavelmente, é conseqüência da dificuldade em se dispersar partículas muito finas na argamassa.

Constatou-se também, no estudo de Santos (1997), a diminuição da demanda de água das argamassas com o aumento do grau de moagem, atribuída à destruição progressiva da estrutura esponjosa da CCA.

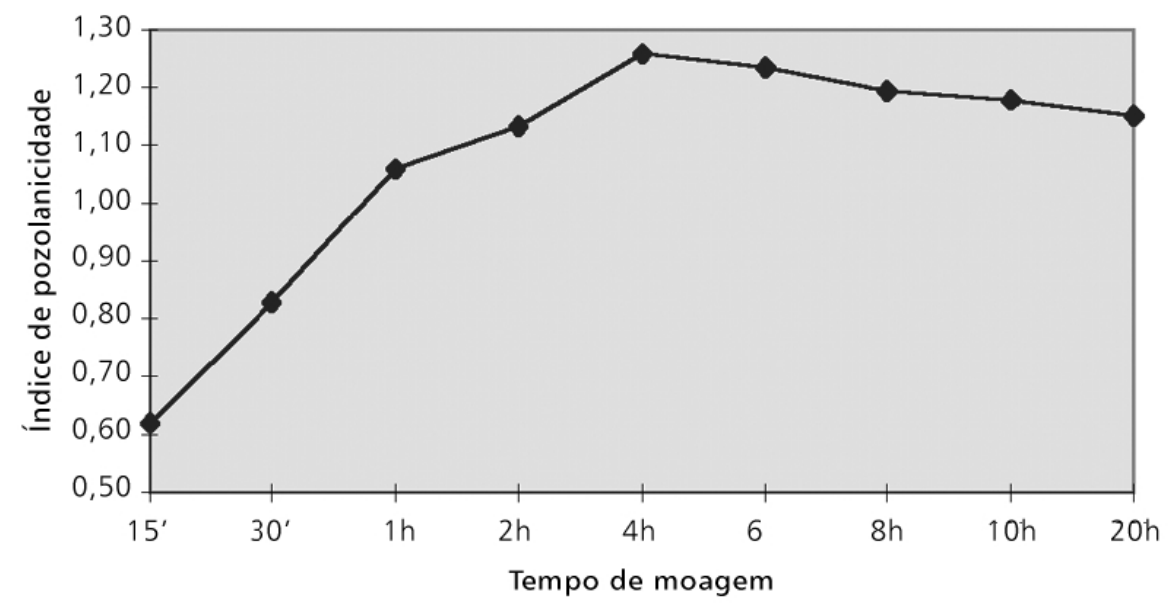

Figura 2.6 - Variação do índice de atividade pozolânica com o grau de moagem. Fonte: Santos, 1997.

Quanto à resistência à compressão obtida nas argamassas com diferentes teores de CCA, observou-se ser de $15 \%$ o teor ótimo de substituição para um máximo de resistência aos 28 dias, e 40\% o teor de substituição para uma resistência equivalente àquela apresentada pela argamassa sem cinza - traço padrão (PRUDÊNCIO Jr et al., 2003). Nesse estudo, a argamassa de referência possuía um traço de 1:3:0,52 (cimento: areia: água) em massa. As substituições do cimento foram feitas em volume. E o traço foi ajustado para manter-se a mesma relação entre água e aglomerante em volume, sem alteração da consistência.

Zhang et al. (1996) estudaram a porosidade na zona de transição em pastas de cimento com CCA. Comprovou-se que a incorporação de CCA reduziu a porosidade da zona de transição em comparação aos exemplares confeccionados apenas com cimento Portland. A espessura da zona de transição entre o agregado e a pasta de cimento também foi reduzida nos exemplares confeccionados com CCA. Aos $20 \mu \mathrm{m}$ de distância do agregado, a porosidade na zona de transição da amostra CONTROLE era $25 \%$, e a da amostra com 
CCA, $18 \%$. Aos $33 \mu$ m, essa relação ficou em 18\% e $9 \%$ respectivamente. A diminuição da porosidade foi mais efetiva na amostra com $10 \%$ de CCA.

Nesse mesmo estudo, comprovou-se que a redução na concentração de $\mathrm{CH}$ na zona de transição também foi mais significativa nas amostras que continham CCA e SCA (sílica ativa), em comparação com a amostra CONTROLE (Figura 2.7).

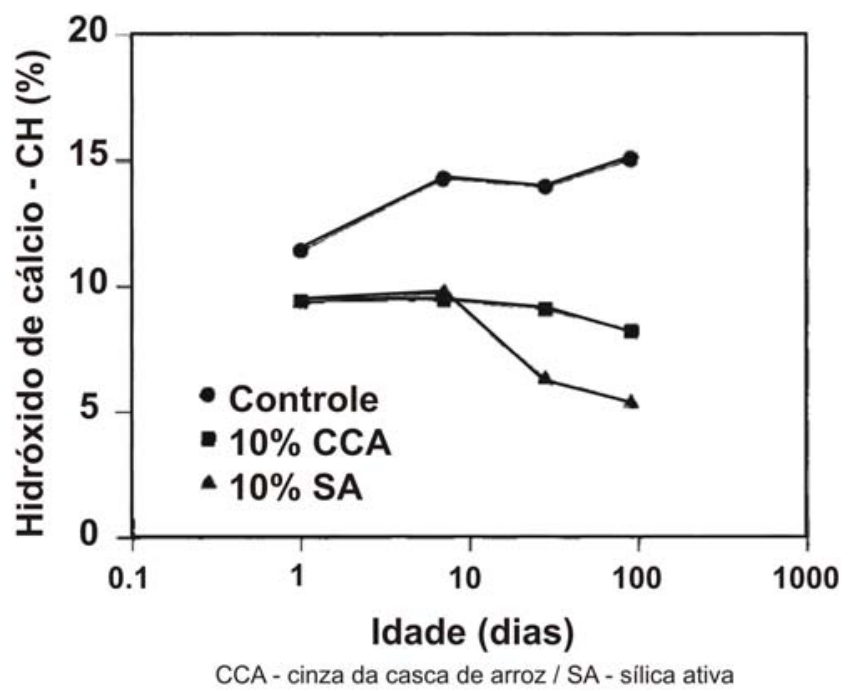

Figura 2.7 - Consumo de $\mathrm{CH}$ em função da idade. Fonte:

Zhang et al., 1996 (adaptado).

A despeito de ser esse um assunto relativamente antigo e também pelos resultados das pesquisas, que demonstram o grande potencial do uso da CCA como pozolanas, as cinzas resultantes da queima da casca de arroz não têm sido muito utilizadas para produção de concreto. Esse fato ocorre tanto no Brasil quanto no exterior. Prudêncio et al. (2003) atribuem tal fato aos elevados índices de carbono residual na cinza (acima de 5\%) que produzem uma coloração cinza-escura no concreto, tornando-o pouco aceito pelo mercado consumidor. Além disso, segundo o mesmo autor, a CCA com alto teor de carbono gera argamassas e concretos com elevado índice de coesão.

Para Rego et al. (2004), a inexpressiva utilização da CCA pela indústria da construção civil é devido, principalmente, ao processo de queima das cascas, ainda ineficaz e sem controle industrial. 


\subsubsection{Cinza da casca do coco da palma}

Os resíduos da moagem da palma, ou dendezeiro (Figura 2.8), incluem as frutas ocas, as cascas, a polpa da palma (pericarpo) e os efluentes da produção. Tem havido bastante esforço no intuito de tirar o máximo benefício econômico desses resíduos, aplicando-os como materiais de construção em concretos (MANNAN \& GANAPATHY, 2004).

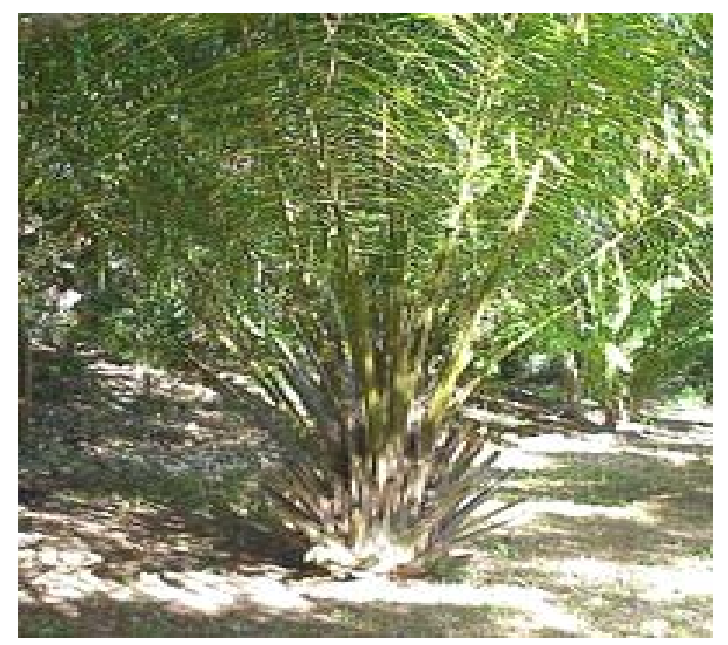

Figura 2.8 - Dendezeiro (Elaeis guineensis). Fonte: WIKIPÉDIA, 2006. ${ }^{12}$

Tay \& Show (1996) investigaram cinzas de casca do coco da produção de dendê e do cacho da mesma planta. Os autores indicaram que a cinza da casca do coco e do cacho do dendê podem substituir, parcialmente, o cimento Portland em até $10 \%$ da massa. Nessa pesquisa o tempo de pega, a consistência e a trabalhabilidade se mantiveram constantes e não foi observada segregação dos materiais.

\subsubsection{Cinza da cama sobreposta de suínos}

A produção de suínos em sistema de cama sobreposta (deep beeding), como mostra a Figura 2.9, constitui-se uma alternativa de manejo. Os dejetos sofrem compostagem in situ com o objetivo de reduzir os custos de poluição (ar, água e solo) e viabilizar economicamente seu uso como adubo de solos (DI CAMPOS, 2005).

Esse sistema de produção em leito, formado por palha ou maravalha, teve sua origem na China, em Hong Kong. Na Europa, a tecnologia de produção de suínos em cama

\footnotetext{
${ }^{12}$ OIL PALM. Disponível em: http//:en.wikipedia.org/wiki.
} 
sobreposta começou a ser estudada no final da década de 80 (KERMARREC, $1999^{13}$ apud DI CAMPOS, 2005). O sistema de produção sobre leito, formado por maravalha ou palha de arroz, foi introduzido no Brasil em 1993 pela EMBRAPA Suínos e Aves. Pesquisadores dessa instituição estudaram, comparativamente, a criação de suínos em três sistemas de produção (cama de maravalha, cama de palha e piso compacto) nas fases de crescimento e terminação (OLIVEIRA, $2000^{14}$ apud DI CAMPOS, 2005). Atualmente, a estimativa de produção da cama sobreposta no Brasil apresenta-se em torno de 13 ton/suíno/ano no Brasil (DI CAMPOS, 2005).

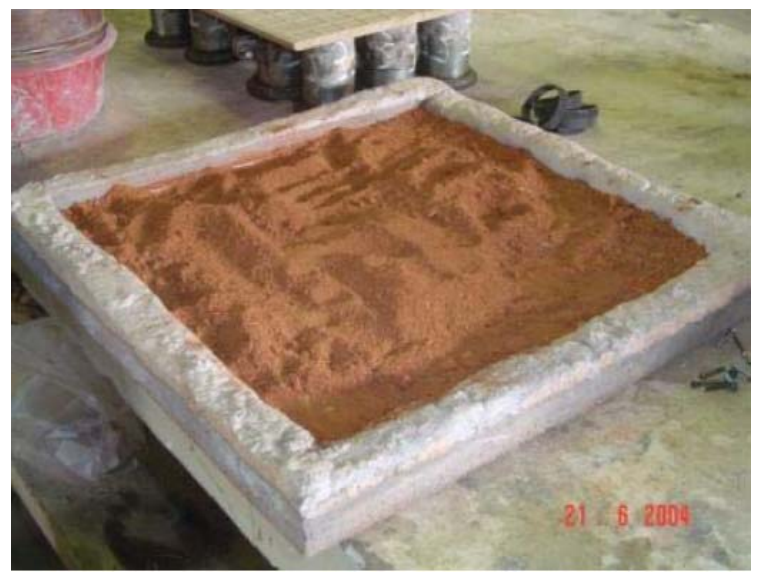

Figura 2.9 - Cinza da cama sobreposta de suínos. Fonte: Di Campos, 2005

Di Campos (2005) estudou o emprego da cinza proveniente da queima controlada da cama de suínos, nas temperaturas de $400^{\circ} \mathrm{C}, 500^{\circ} \mathrm{C}, 600^{\circ} \mathrm{C}$, em matrizes de cimento Portland.

A autora destaca que as cinzas de cama sobreposta de suínos, calcinadas a $600^{\circ} \mathrm{C}$ (material passante na peneira $n^{\circ} 325$ ) e com teor de substituição de $30 \%$, tiveram melhor desempenho no ensaio de resistência à compressão axial, com resultado de 36,0 MPa aos 28 dias, em relação às argamassas CONTROLE (28,2 Mpa), e argamassa com 10\% de sílica ativa (32,6 MPa), indicando que a cinza da cama sobreposta de suínos pode promover atividade pozolânica em matrizes cimentícias.

Zardo et al. (2005) também analisaram cinzas de resíduos agroindustriais para possível aproveitamento na construção civil: a cinza da cama sobreposta de suínos e a

\footnotetext{
${ }^{13}$ KERMARREC, C. (1999). Bilan et transformations de l'azote en élevage intensif de procs sur litière. 1999. 186f. Tese (Doutorado). - Universidade de Rennes, France.

${ }^{14}$ OLIVEIRA, P. A. V. (2000). Produção de suínos em sistema deep beeding: experiência brasileira. In: Seminário Internacional de Suinocultura, 2000, São Paulo. Anais... Concórdia : EMBRAPA Suínos e Aves, p.89-100.
} 
cinza do bagaço da cana. Os resultados indicaram que a cinza da cama sobreposta de suínos, por ter processo de queima controlado e alto teor de casca de arroz, apresenta maior potencial pozolânico que a cinza do bagaço da cana.

\subsubsection{Cinza do bagaço da cana-de-açúcar}

A cinza do bagaço de cana-de-açúcar também vem sendo largamente estudada como adição em materiais cimentícios (FREITAS, 1996; HERNÁNDEZ et al., 1998; CORDEIRO et al., 2005; entre outros), principalmente pelo aumento da geração desse resíduo em função da alta produção de álcool combustível e de açúcar nos últimos anos.

Atualmente, o Brasil é responsável pela produção de cerca de $60 \%$ do álcool etílico consumido no planeta e é o maior produtor mundial de açúcar.

De acordo com o Ministério da Agricultura, Pecuária e Abastecimento - MAPA (com base nos dados gerados pelo Instituto Brasileiro de Geografia e Estatística - IBGE), a produção de cana-de-açúcar na safra 2006/2007 superou 470 milhões de toneladas, gerando cerca de 112 milhões de toneladas de bagaço. A Região Centro-Sul é responsável por mais de $80 \%$ da produção do setor sucroalcooleiro, sendo São Paulo o principal estado produtor (CONAB, 2007b). A Figura 2.10 mostra a crescente evolução da produtividade da cana-de-açúcar no Brasil desde o início do Pró-Álcool ${ }^{15}$.

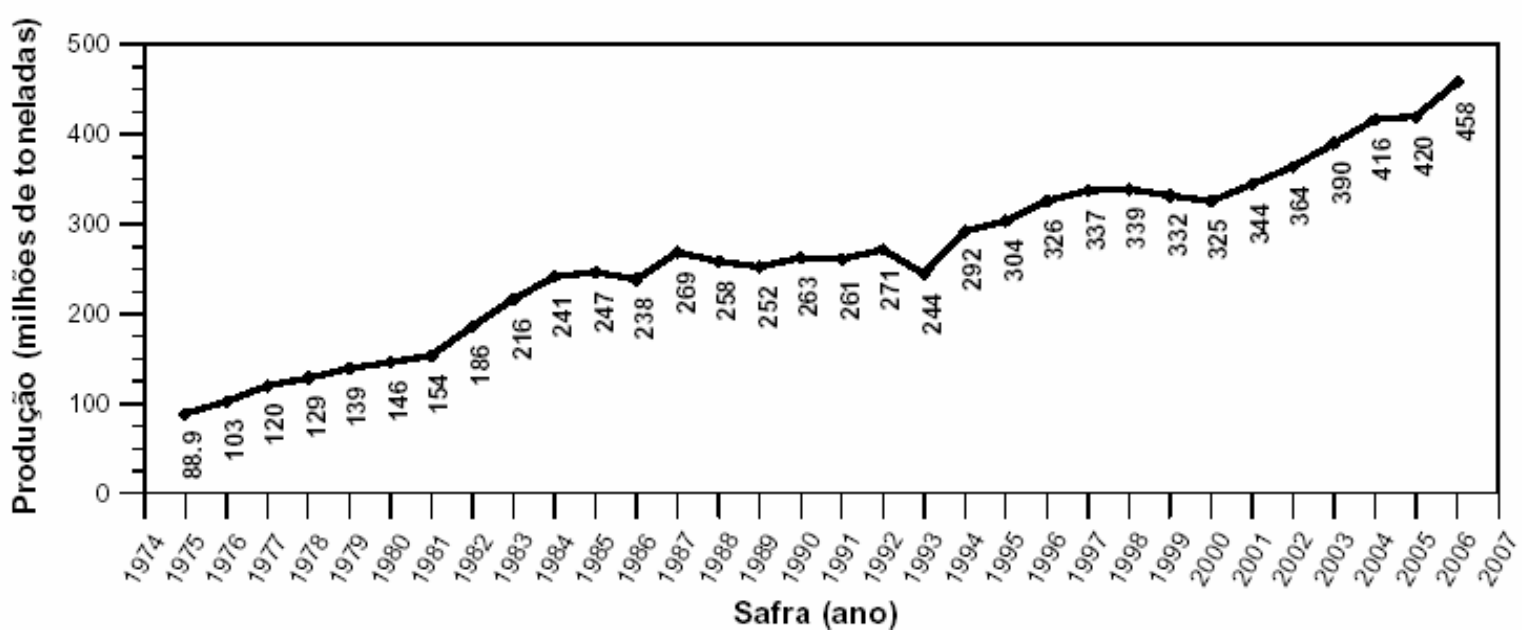

Figura 2.10 - Evolução da produtividade da cana-de-açúcar no Brasil. Fonte: CONAB, 2007b.

\footnotetext{
15 Pró-Álcool - Programa Brasileiro do Álcool. Disponível em: <http://www.biodieselbr.com/ proalcool/proalcool.htm>. Acesso em: 29 Out. 2007.
} 
Atualmente, um dos problemas enfrentados pelos administradores das usinas é a geração de cinzas residuais, provenientes da queima do bagaço, e sua disposição, que pode ser temporária (armazenamento para reintrodução no cultivo da cana) ou definitiva no ambiente (SOUZA et al., 2007). Na maior parte dos casos, as cinzas do bagaço da cana-deaçúcar (CBC) residuais são aproveitadas no campo como adubação orgânica nas lavouras de cana (apesar de ser um material com poucos nutrientes) ou descartadas na natureza sem um manejo eficiente (Figura 2.11).

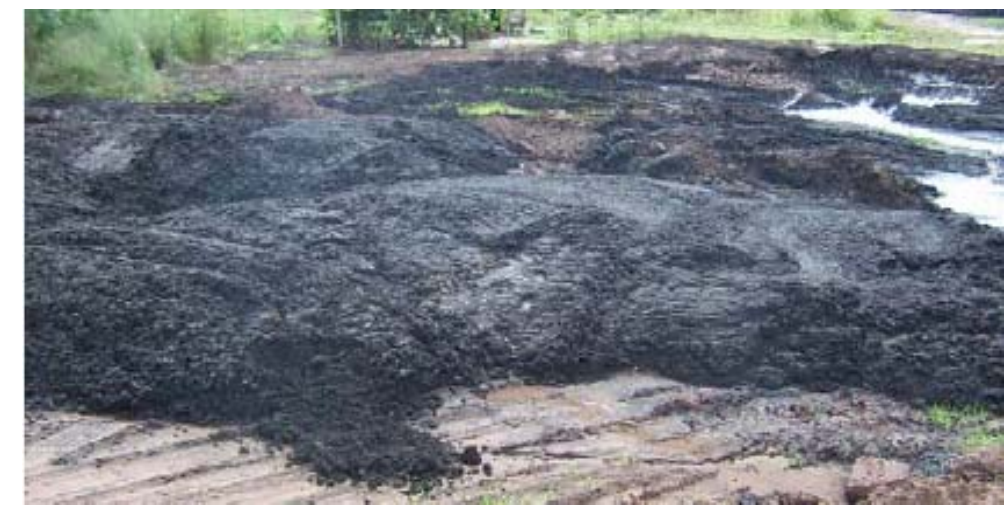

Figura 2.11 - Disposição final da CBC. Fonte: SOUZA et al., 2007.

Pesquisas indicam a possibilidade de uso da cinza do bagaço da cana-de-açúcar como adição mineral para concretos. Hernández et al. (1998) apontam a semelhança entre as composições químicas de uma cinza residual do bagaço, originária de Villa Clara (Cuba), e de uma cinza da casca de arroz, adição mineral de reconhecida reatividade. Além disso, estudos incipientes demonstram a viabilidade de utilização da cinza residual do bagaço em conjunto com cimento Portland (FREITAS et al., 1998; SINGH et al., 2000; CORDEIRO et al., 2005; SOUZA et al., 2007).

Todavia, um inconveniente da CBC consiste na "contaminação" por partículas de quartzo provindas da areia, que chegam à unidade de beneficiamento aderida à cana-deaçúcar e não é totalmente retirada durante a etapa de lavagem da cana. A reatividade da cinza pode ser comprometida por esse tipo de contaminação, uma vez que o quartzo, ao contrário da sílica em estado amorfo, é um material estável quimicamente (CORDEIRO et al.,2005).

Mesmo levando-se em consideração a contaminação por quartzo proveniente da areia, Cordeiro et al. (2005) obtiveram resultados bastante satisfatórios nos testes de pozolanicidade com a cal (NBR 5751/92) e com o cimento (NBR 5752/92), comparando-se também com o quartzo moído (Tabela 2.4). 
Tabela 2.4 - Composição química e propriedades físicas da cinza residual do bagaço da cana-de-açúcar e do quartzo moído.

\begin{tabular}{ccc}
\hline Composto & Cinza do bagaço (\%) & Quartzo moído (\%) \\
\hline $\mathrm{SiO}_{2}$ & 78,30 & 97,00 \\
\hline $\mathrm{Al}_{2} \mathrm{O}_{3}$ & 8,60 & 0,40 \\
\hline $\mathrm{Fe}_{2} \mathrm{O}_{3}$ & 3,60 & 0,10 \\
\hline $\mathrm{CaO}$ & 2,20 & 0,50 \\
\hline $\mathrm{Na}_{2} \mathrm{O}$ & 0,1 & - \\
\hline $\mathrm{K}_{2} \mathrm{O}$ & 3,50 & - \\
\hline $\mathrm{MgO}$ & 0,10 & 0,50 \\
\hline $\mathrm{P}_{2} \mathrm{O}_{5}$ & 1,10 & - \\
\hline Perda ao fogo & 0,42 & 0,50 \\
\hline
\end{tabular}

Fonte: Cordeiro et al., 2005

No caso dos ensaios de índice de atividade pozolânica com cal, a diferença entre os valores alcançados pelas adições minerais é ainda mais significativa $(84,4 \%)$, considerandose a mínima resistência à compressão o valor de $6,00 \mathrm{MPa}$, estipulado pela norma NBR 5751 (ABNT, 1992) para materiais pozolânicos. Para o ensaio de reatividade com o cimento, os valores de índice de atividade pozolânica para a cinza do bagaço e para o quartzo moído, foram, respectivamente, iguais a $81 \%$ e $62 \%$. A diferença entre os índices mostra-se significativa (19\%) e somente a cinza do bagaço de cana-de-açúcar apresenta valor superior a 75\%, mínimo estabelecido pela norma NBR 12653 (ABNT, 1992) para que um material possa ser classificado como pozolânico.

Ao final do trabalho, Cordeiro et al. (2005) afirmaram que a cinza residual do bagaço de cana-de-açúcar pode apresentar reatividade com cimento Portland e com cal quando comparado com o quartzo.

No estudo de Hernández et al. (1998), foi feita uma comparação entre pastas de cal, utilizando 3 tipos de cinzas: a cinza da casca do arroz (CCA) - a série de controle; a cinza do bagaço da cana-de-açúcar (CBCA); e a cinza da palha da cana-de-açúcar (CPCA) Tabela 2.5. 
Tabela 2.5 - Composição química - CCA e CBC

\begin{tabular}{cccc}
\hline & \multicolumn{3}{c}{ \% em massa } \\
\cline { 2 - 4 } Componente & CCA & CBCA & CPCA \\
\hline $\mathrm{SiO}_{2}$ & 71,74 & 72,74 & 59,06 \\
\hline $\mathrm{Al}_{2} \mathrm{O}_{3}$ & 5,61 & 5,26 & 4,75 \\
\hline $\mathrm{Fe}_{2} \mathrm{O}_{3}$ & 3,47 & 3,92 & 3,18 \\
\hline $\mathrm{TiO}_{2}$ & 0,38 & 0,32 & 0,34 \\
\hline $\mathrm{CaO}$ & 10,42 & 7,99 & 19,59 \\
\hline $\mathrm{MgO}$ & 1,98 & 2,78 & 2,25 \\
\hline $\mathrm{SO}_{3}$ & 0,50 & 0,13 & 1,37 \\
\hline $\mathrm{K}_{2} \mathrm{O}$ & 3,62 & 3,47 & 4,75 \\
\hline $\mathrm{Na}_{2} \mathrm{O}$ & 0,40 & 0,84 & 0,73 \\
\hline $\mathrm{P}_{2} \mathrm{O}_{5}$ & 0,89 & 1,59 & 1,67 \\
\hline perda ao fogo & 0,78 & 0,77 & 2,05 \\
\hline total & 99,79 & 99,81 & 99,74 \\
\hline
\end{tabular}

Fonte: Hernández et al., 1998 (adaptado).

Observou-se uma vantagem da cinza da palha em relação à cinza do bagaço, uma vez que esta reagiu mais rapidamente com o hidróxido de cálcio $(\mathrm{CH})$ da pasta de cal (Tabela 2.6).

Tabela 2.6 - Medições por DrX, consumo de $\mathrm{CH}$.

\begin{tabular}{cccc}
\hline Traço & Amostra & Idade & Fases detectadas \\
\hline \multicolumn{4}{c}{ Cinza do bagaço da cana-de-açúcar (CBCA) } \\
\hline 1 & Cinza in natura & - & Quartzo, cristobalita, calcita. \\
\hline 2 & Pasta hidratada & 7 dias & Quartzo, cristobalita, calcita, CSH, portlandita. \\
\hline 3 & Pasta hidratada & 28 dias & Quartzo, cristobalita, calcita, CSH, portlandita. \\
\hline 4 & Pasta hidratada & 43 dias & Quartzo, cristobalita, calcita, CSH, portlandita. \\
\hline 5 & Cinza in natura & - & Quartzo, cristobalita, calcita. \\
\hline 6 & Pasta hidratada & 7 dias & Quartzo, cristobalita, calcita, CSH, portlandita. \\
\hline 7 & Pasta hidratada & 28 dias & Quartzo, cristobalita, calcita, CSH. \\
\hline 8 & Pasta hidratada & 43 dias & Quartzo, cristobalita, calcita, CSH. \\
\hline
\end{tabular}

Fonte: Hernández et al., 1998 (adaptado).

Quanto à resistência à compressão, constatou-se o melhor desempenho para os corpos-de-prova prismáticos confeccionados com a cinza da palha da cana-de-açúcar (CPCA), conforme Tabela 2.7 . 
Tabela 2.7 - Resultados do ensaio de resistência à compressão - CBCA .

\begin{tabular}{ccc}
\hline Amostra & Idade (dias) & Resistência à compressão (MPa) \\
\hline Cal-Pozolana CBCA & 7 & 2,7 \\
\hline Cal-Pozolana CBCA & 28 & 7,7 \\
\hline Cal-Pozolana CPCA & 7 & 7,2 \\
\hline Cal-Pozolana CPCA & 28 & 13,7 \\
\hline
\end{tabular}

Fonte: Hernández et al., 1998 (adaptado).

\subsubsection{Cinza da serragem da madeira}

O resíduo do processamento da madeira é denominado serragem ou pó-de-serra. Pode causar danos tanto à saúde quanto ao meio ambiente, quando não feita a correta disposição final do material. A maior parte da utilização da serragem atualmente se dá como combustível, e uma pequena quantidade como material fíler ou agregados para concretos. A utilização da cinza da serragem como substituto parcial do cimento Portland é recente e pode contribuir em dois aspectos: a redução da eliminação deste resíduo no meio ambiente e a diminuição da quantidade/custo de cimento utilizado em argamassas e concretos (ELINWAH \& MAHMOOD, 2004).

Para esse estudo, as propriedades químicas e físicas da cinza da serragem foram determinadas no laboratório National Steel Council em Kaduna, Nigéria, e os resultados encontram-se nas tabelas 2.8 e 2.9 .

A análise química demonstrou que a sílica $(67,20 \%)$ e o cálcio $(9,98 \%)$ são os elementos predominantes. A porcentagem total de $\mathrm{SiO}_{2}+\mathrm{Al}_{2} \mathrm{O}_{3}+\mathrm{Fe}_{2} \mathrm{O}_{3}$ ficou em $73,55 \%$, que ultrapassa o mínimo (70\%) especificado pela ASTM C-618 ${ }^{16}$.

\footnotetext{
${ }^{16}$ ASTM C618-78. (1978). Specification for fly ash and raw or calcined natural pozzolana for use as a material admixture in Portland cement concrete.
} 
Tabela 2.8 - Análise química da cinza da serragem

\begin{tabular}{cc}
\hline Componentes & Teor (\%) \\
\hline $\mathrm{Al}_{2} \mathrm{O}_{3}$ & 4,09 \\
\hline $\mathrm{Fe}_{2} \mathrm{O}_{3}$ & 2,26 \\
\hline $\mathrm{SiO}_{2}$ & 67,20 \\
\hline $\mathrm{CaO}$ & 9,98 \\
\hline $\mathrm{MgO}$ & 5,80 \\
\hline $\mathrm{MnO}$ & 0,01 \\
\hline $\mathrm{Na}_{2} \mathrm{O}$ & 0,08 \\
\hline $\mathrm{K}_{2} \mathrm{O}$ & 0,11 \\
\hline $\mathrm{P}_{2} \mathrm{O}_{5}$ & 0,48 \\
\hline $\mathrm{SO}_{2}$ & 0,45 \\
\hline
\end{tabular}

Fonte: Elinwah \& Mahmood, 2004 (adaptado).

Mesmo possuindo elevado teor de sílica, o ensaio de resistência à compressão demonstrou uma redução de resistência à medida em que se aumentou a substituição do cimento por cinza de serragem, em torno de $7 \%$ de diferença, para a amostra com $5 \%$ de adição de serragem em relação à amostra padrão (Tabela 2.9).

Tabela 2.9 - Ensaio de resistência à compressão - cinza da serragem

\begin{tabular}{ccccc}
\hline \multirow{2}{*}{ Cinza (\%) } & \multicolumn{4}{c}{ Resistência à compressão (MPa) } \\
\cline { 2 - 5 } & 3 dias & 7 dias & 14 dias & 28 dias \\
\hline 0 & 16,40 & 17,63 & 21,74 & 23,12 \\
\hline 5 & 12,89 & 13,91 & 19,65 & 21,60 \\
\hline 10 & 12,13 & 13,11 & 16,00 & 18,14 \\
\hline 15 & 8,27 & 8,98 & 12,00 & 15,74 \\
\hline 20 & 7,29 & 7,96 & 9,47 & 11,52 \\
\hline 25 & 4,49 & 5,96 & 8,54 & 9,25 \\
\hline 30 & 4,32 & 5,29 & 6,54 & 8,76 \\
\hline
\end{tabular}

Fonte: Elinwah \& Mahmood, 2004

Outros autores (UDOEYO \& DASHIBIL, 2002; UDOEYO et al., 2006) concluíram que, após análises com a cinza da serragem obtida por queima sem controle, $\left(\mathrm{SiO}_{2}+\mathrm{Al}_{2} \mathrm{O}_{3}+\right.$ $\mathrm{Fe}_{2} \mathrm{O}_{3}>70 \%$ ) tanto a trabalhabilidade quanto a resistência à compressão tiveram seus valores decrescidos em relação ao exemplar de cimento Portland. Fato contrário ocorreu com o tempo de começo e fim de pega, que teve seus valores aumentados. Um dado a ser considerado, mostrado na Figura 2.12, é o aumento da demanda de água à medida que se aumenta o teor de substituição de cinza (UDOEYO et al., 2006). 


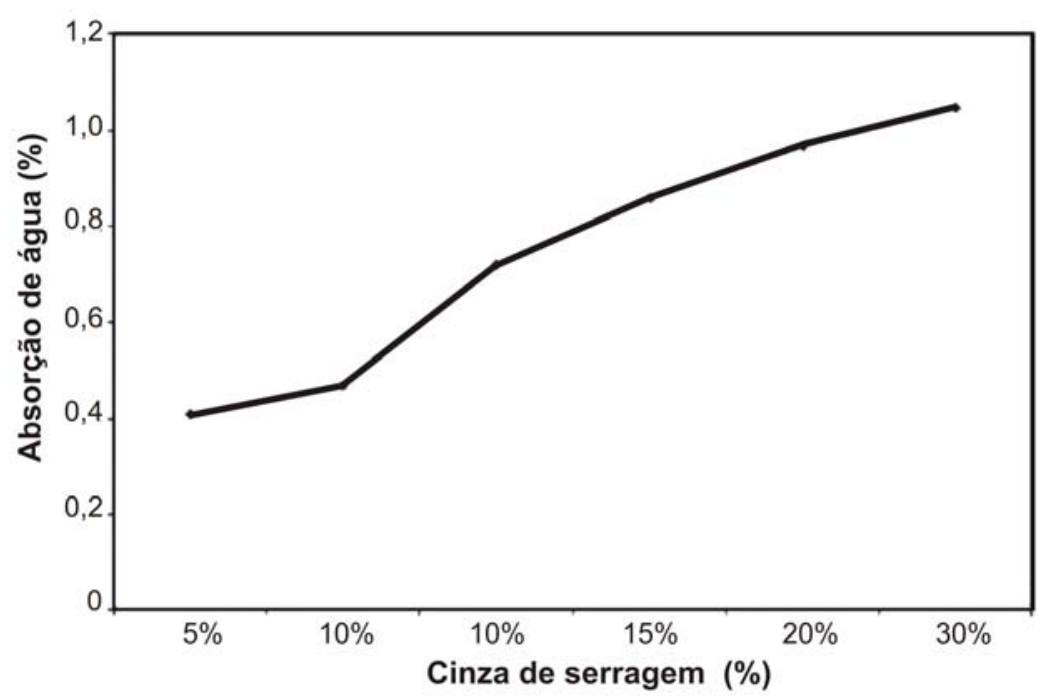

Figura 2.12 - Aumento na demanda de água versus teor de cinza de serragem (resíduo de madeira). Fonte: Udoeyo et al., 2006 (adaptado)

Esses resultados demonstram uma semelhança em relação aos obtidos por Elinwah \& Mahmood (2004), indicando que a cinza da serragem apresenta-se como um resíduo potencialmente utilizável como adição mineral em materiais cimentícios.

\subsubsection{Cinza da casca do eucalipto}

Dentre os resíduos da indústria do papel, destaca-se, entre outros, o uso das fibras para reforços de matrizes frágeis e o reaproveitamento da cinza da casca do eucalipto em matrizes cimentícias (NOLASCO \& AGNESINI, 1993; SILVA et al.,1993).

A cinza de casca de eucalipto, resíduo do processo de fabricação de papel da empresa Aracruz, tem sido estudada por vários pesquisadores da UFES - Universidade Federal do Espírito Santo.

Silva et al. (1993) estudaram vários resíduos industriais da região da cidade de Vitória, entre eles a cinza da casca de eucalipto, para aproveitamento em componentes para construção civil. Foram realizados ensaios de resistência à compressão, ensaio de tração por compressão diametral, assim como massa específica, absorção e volume de vazios permeáveis utilizando corpos-de-prova cilíndricos $(50 \times 100 \mathrm{~mm})$. Os resultados mostraram um aumento da resistência à compressão simples dos corpos-de-prova de argamassa com adição de $5 \%$ de cinza em relação aos de referência nas primeiras idades, o que não se repetiu em idades avançadas (Tabela 2.10 ). 
Tabela 2.10 - Resistência à compressão de corpos-de-prova confeccionados com a cinza da casca do eucalipto - MPa

\begin{tabular}{cccccccc}
\hline & $\mathbf{7}$ dias & 14 dias & 28 dias & 63 dias & 91 dias & 140 dias & 217 dias \\
\hline Referência & 20,7 & 29,4 & 36,3 & 49,5 & 52,7 & 55,3 & 63,7 \\
\hline $\mathbf{5 \%}$ cinza & 26,7 & 29,7 & 37,7 & 48,4 & 47,3 & 43,8 & 55,2 \\
\hline
\end{tabular}

Fonte: Silva et al., 1993.

Silva \& Souza (1995) estudaram o aproveitamento do resíduo da indústria de celulose/papel e entulho de obra em componentes de construção (painéis e blocos). Os melhores resultados foram obtidos com a substituição de $30 \%$ da massa de cimento pela cinza de casca de eucalipto (resíduo da indústria de celulose/ papel) e pela substituição do agregado pelo resíduo de construção. Nessa época, a Aracruz Celulose, empresa fornecedora do resíduo para essa pesquisa, informou ser de US\$500.000 dólares/ano os gastos com execução de aterros para seus resíduos.

Silva et al. (1996) analisaram em outro estudo a composição química do resíduo da produção de eucalipto, calcinado a $1000^{\circ} \mathrm{C}$ (Tabela 2.11).

Após a análise química foram confeccionados corpos-de-prova de argamassa de $50 \times 100 \mathrm{~mm}$, com o objetivo de avaliar as propriedades mecânicas (resistência à compressão e à tração por compressão diametral) e físicas (massa específica, absorção e volume de vazios permeáveis até a idade de 230 dias).

Tabela 2.11 - Análise química da cinza da casca de eucalipto calcinada a $1000^{\circ} \mathrm{C}$

\begin{tabular}{ccccccccccc}
\hline Óxidos & $\mathrm{SiO}_{2}$ & $\mathrm{CaO}$ & $\mathrm{MgO}$ & $\mathrm{Fe}_{2} \mathrm{O}_{3}$ & $\mathrm{Al}_{2} \mathrm{O}_{3}$ & $\mathrm{SO}_{3}$ & $\mathrm{Na}_{2} \mathrm{O}$ & $\mathrm{K}_{2} \mathrm{O}$ & $\mathrm{PF}$ & $\mathrm{CO}_{2}$ \\
\hline$\%$ & 13,10 & 55,70 & 7,98 & 1,05 & 5,02 & 10,50 & 2,82 & 1,50 & 40,50 & 10,40 \\
\hline
\end{tabular}

Fonte: Silva et al., 1996

Os resultados iniciais obtidos demonstraram ser possível a substituição de até $30 \%$ de cinza da casca do eucalipto, sem prejudicar a resistência à compressão. No ano de 1996, o Instituto de Pesquisas Tecnológicas - IPT deu início a um programa de caracterização da cinza da casca do eucalipto. Não foram encontrados dados na literatura sobre a cinza da casca do eucalipto após essa data. 


\subsubsection{Cinza da casca da castanha-do-pará}

Observa-se, no estado do Pará, um crescente aumento de resíduos sólidos, seja de origem industrial ou de origem agrícola, decorrente, principalmente, da conquista de mercado por parte dos produtos paraenses e do maior desenvolvimento da sua indústria. Esse aumento de resíduos fez com que se iniciassem estudos visando proporcionar uma forma de empregá-los, evitando, desse modo, os problemas decorrentes da sua presença. Dentre esses produtos, destaca-se a casca da castanha-do-pará (CAMELO et al., 2005).

Com esta motivação, Camelo et al. (2005) realizaram um estudo exploratório para avaliar o potencial pozolânico dessa cinza e sua utilização como adição para produtos cimentícios, obtendo resultados poucos expressivos. Para que a casca da castanha-do-pará possa ser utilizada como adição mineral, assim como na cinza da casca de arroz, a mesma necessitou passar por processo de calcinação. Após transformação da casca em cinza, Camelo et al. (2005) observaram a elevada perda ao fogo do material, o que, segundo os autores, pode ter sido um dos determinantes para a pouca reatividade da cinza.

$\mathrm{Na}$ avaliação do material obtido, em relação ao aspecto químico, verifica-se o baixo teor de elementos reativos $\left(\mathrm{SiO}_{2}, \mathrm{Al}_{2} \mathrm{O}_{3}, \mathrm{Fe}_{2} \mathrm{O}_{3}\right)$ e elevada perda ao fogo residual, o que conseqüentemente posicionou a cinza obtida fora dos limites definidos pela NBR 12653 (ABNT, 1992). Essa situação também foi observada, em menor escala, por Cincotto \& Kaupatez (1988) no estudo do bagaço da cana-de-açúcar, da casca de amendoim e da casca de mamona.

Camelo et al. (2005) obtiveram resultados que atestam que a atividade pozolânica da cinza da casca da castanha-do-pará (CCCP), em substituição ao cimento Portland, obteve valores superiores aos da exigência normativa da NBR 12653 (Tabela 2.12).

Além dos satisfatórios resultados no ensaio de pozolanicidade com o cimento Portland, obteve-se que a quantidade de água requerida pela argamassa foi $13 \%$ superior à obtida na argamassa de referência, menor que o valor máximo de $15 \%$ exigido para o uso de materiais pozolânicos. Segundo o autor, esse aumento deve-se, talvez, à elevada finura do material em relação ao cimento, o que faz com que seja necessária uma maior quantidade de água para que a argamassa possa atingir a consistência definida pela NBR 12653. 
Tabela 2.12 - Resultados dos ensaios de atividade pozolânica - CCCP

\begin{tabular}{|c|c|c|c|c|c|}
\hline $\begin{array}{l}\text { Material } \\
\text { utilizado }\end{array}$ & Ensaio & Norma & Idade & $\begin{array}{l}\text { Valor } \\
\text { obtido }\end{array}$ & $\begin{array}{c}\text { Exigência } \\
\text { normativa NBR } \\
12653 / 92\end{array}$ \\
\hline \multirow{3}{*}{ CCСP } & $\begin{array}{l}\text { Atividade pozolânica com o } \\
\text { cimento Portland ARI, com } \\
\text { adição e sem aditivo }\end{array}$ & $\begin{array}{c}\text { NBR } \\
5752 / 92\end{array}$ & 28 dias & $79,67 \%$ & $>75 \%$ \\
\hline & $\begin{array}{l}\text { Atividade pozolânica com o } \\
\text { cimento Portland ARI, com } \\
\text { adição e uso de aditivo }\end{array}$ & $\begin{array}{c}\text { NBR } \\
5752 / 92\end{array}$ & 28 dias & $106,54 \%$ & - \\
\hline & $\begin{array}{c}\text { Atividade pozolânica com a } \\
\text { cal }\end{array}$ & $\begin{array}{c}\text { NBR } \\
5751 / 92\end{array}$ & 7 dias & $<1,00 \mathrm{MPa}$ & $>6,00 \mathrm{Mpa}$ \\
\hline
\end{tabular}

Fonte: Camelo et al., 2005 (adaptado)

Camelo et al. (2005) concluíram seu estudo constatando a possibilidade da obtenção de pozolanas provenientes da casca da castanha-do-pará, desde que observados os parâmetros referentes à sua composição química, ao seu processo de calcinação e à moagem.

\subsubsection{Considerações}

Ao final deste capítulo, pode-se destacar a importância da continuação dos estudos a respeito do aproveitamento das cinzas agroindustriais. $\grave{A}$ falta de pesquisas mais aprofundadas agrega-se o amplo universo de possibilidades de utilização dessas cinzas para uso em matrizes cimentícias. As técnicas de caracterização, de análise da pozolanicidade e do comportamento mecânico se mostram incompletas quando de trata de uma investigação mais ampla quanto a viabilidade técnica de uma cinza para uso em matrizes cimentícias. São necessários, além desses estudos, análises quanto aos aspectos microestruturais, ambientais e de durabilidade.

No capítulo seguinte, apresenta-se a cinza da casca da castanha de caju, seu processo de obtenção e os estudos realizados até o momento com os produtos derivados da cajucultura. 
Capítulo

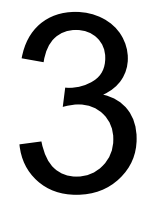

A CINZA DA CASCA DA CASTANHA DE CAJU

O caju é uma espécie nativa dos tabuleiros e dunas do Brasil, despontando sempre vizinho ao mar. Ocorreu nesse local a mais antiga descrição do fruto, feita por André Thevet, em 1558, comparando-o a um ovo de pata. Um pouco depois, Maurício de Nassau teve que proteger o caju por decreto, uma vez que os portugueses estavam levando mudas de cajueiro para as suas colônias na África e na Ásia, nos séculos XVI e XVII (LOPES NETO, 1997). Tal embargo fez com que o doce de caju em compotas pudesse chegar às melhores mesas da Europa ${ }^{17}$.

Lopes Neto (1997) afirmou que a área mundial ocupada com o cajueiro apresenta-se, atualmente, compreendida entre as latitudes $30^{\circ}$ Norte e $31^{\circ} \mathrm{Sul}$, de modo que o cajueiro encontra-se vegetando em grande número de países e, em muitos deles, está perfeitamente adaptado. O cajueiro encontra condições ideais de cultivo no litoral, onde se adapta melhor em solo seco, devendo seu plantio ser realizado na estação chuvosa, geralmente entre os meses de janeiro e junho. Ocorre, principalmente, em locais com clima tropical e subtropical, o que justifica sua boa adaptação aos solos brasileiros. Uma árvore com 4 anos de idade pode produzir de 100 a $150 \mathrm{~kg}$ de amêndoas por ano (PAIVA et al., 2000).

Muitos estudos sobre o caju e seus possíveis benefícios vêm sendo realizados e já obtiveram-se resultados positivos em algumas pesquisas, as quais se aprofundaram em específicas partes da fruta: casca, bagaço, castanha e sementes. Os resultados são direcionados principalmente para as áreas de tecnologia e saúde.

O óleo da castanha de caju, também conhecido como cardol ou líquido da castanha do caju (LCC), por exemplo, é utilizado há tempos pela indústria como componente de fungicidas, inseticidas, vernizes, pinturas, adesivos e também plásticos de lonas para freios.

${ }^{17}$ CAJU. Disponível em <http://pt.wikipedia.org/wiki/Caju>. Acesso em: 10 out. 2006. 
Outro estudo relacionado ao cardol foi desenvolvido na área de química fina, pelo Parque de Desenvolvimento Tecnológico (PADETEC) em parceria com universidades do Brasil, Itália, Alemanha, Argentina e, também, a Petrobrás. Trata-se do uso de aditivo biológico à base de LCC nos derivados do petróleo, combustíveis e lubrificantes. No PADETEC foi criada uma estratégia denominada Plataforma do Caju, projeto voltado para pesquisas científicas visando desenvolver novos produtos alimentícios com base no aproveitamento do pedúnculo em parceria com a indústria CIONE - Companhia Industrial de Óleos do Nordeste, com financiamento do Fundo Verde Amarelo da FINEP (SECITECE, 2007).

$\mathrm{Na}$ área da saúde, uma importante pesquisa foi desenvolvida no Laboratório de Pesquisa e Ensino em Síntese Orgânica, da Universidade de Brasília. Trata-se da extração da substância lasiodiplodina a partir do ácido anacárdico, proveniente do caju. Tal substância tem o potencial de atuar contra a leucemia e encontra-se em processo de sintetização a partir de substâncias químicas industrializadas (CAPOBIANCO, 2007).

A Embrapa Agroindústria de Alimentos, juntamente com a Embrapa Agroindústria Tropical (Fortaleza-CE), confeccionaram biscoitos, pães, snacks e até bolos a partir da mistura de $50 \%$ de farinha de arroz e $50 \%$ de bagaço do caju. Os produtos apresentaram um alto teor de fibras (SANTOS, 2007).

Situada no Parque de Desenvolvimento Tecnológico da Universidade Federal do Ceará, a Aglodeste, microempresa que trabalha com subprodutos e resíduos, obteve materiais aglomerados a partir do LCC. Entre esses materiais, encontram-se as resinas fenólicas que podem ser processadas com resíduos orgânicos ou inorgânicos para a obtenção de placas. Esses produtos atestaram boa resistência mecânica ao contato com a água, ao ataque de roedores e cupins, ao isolamento acústico e térmico, podendo ser furado, parafusado ou serrado. O processo de produção de aglomerados permite o uso de uma série de resíduos de difícil aproveitamento: casca do arroz, casca do coco, restos de papel usado, materiais granulados ou pulverizados de extrações minerais, serragem e resíduos de madeireiras. Os aglomerados podem ser utilizados de diversas maneiras: pisos, divisórias, forros, móveis para cozinhas, telhas para isolamento térmico. Pode-se também obter um material granulado, que pode ser adicionado à argamassa de revestimento com a finalidade de se obter um melhor isolamento térmico e acústico dos ambientes (AGLODESTE, 2007). 
O bagaço do caju (pedúnculo) também foi investigado por pesquisadores da área de Engenharia de Alimentos da Universidade Federal do Ceará. Eles afirmaram que esse subproduto representa um dos principais resíduos da produção do caju e que, ao ser incinerado, sofre redução de $97 \%$ do volume inicial. As análises da cinza residual (peduncle bagasse ash) indicaram como principais fases cristalinas $\mathrm{O}_{\mathrm{KHCO}_{3}}$ - bicarbonato de potássio - $(54,17 \%)$ e o $\mathrm{K}_{2} \mathrm{SO}_{4}$ - sulfato de potássio - $(34,08 \%)$. Segundo os pesquisadores, esses resultados apontaram para a utilização dessa cinza como fonte não-perecível de potássio, enxofre e magnésio (SANTOS et al., 2007).

Nota-se, portanto, que várias instituições brasileiras, distribuídas em vários estados, encontram-se desenvolvendo pesquisas que tratam do aproveitamento dos subprodutos derivados do caju. No entanto, segundo Paiva et al. (2000), o Estado do Ceará detém, no Brasil, a maior parte da produção e exportação de castanha de caju. A castanha apresentase como o primeiro produto de exportação desse Estado, com uma produção de 300.000 toneladas por ano (CONAB, 2008). Essa produção destina-se, tradicionalmente, ao mercado externo, gerando, em média, divisas da ordem de 150 milhões de dólares anuais.

As castanhas do Estado do Ceará têm destino em mais de 30 países, sendo os Estados Unidos o principal importador, com $64 \%$ do total exportado (AGROPOLOS, 2008). Esse país é o maior consumidor mundial de castanhas, que as consome principalmente como petiscos - snacks (LOPES NETO, 1997).

$\mathrm{Na}$ Tabela 3.1 verifica-se a participação da castanha do caju nas exportações cearenses.

Tabela 3.1 - Posição do setor de exportações de castanha de caju no Estado do Ceará

\begin{tabular}{cccc}
\hline Ano & $\begin{array}{c}\text { Exportações } \\
\text { (Mil Toneladas) }\end{array}$ & $\begin{array}{c}\text { Participação } \\
(\%)\end{array}$ & $\begin{array}{c}\text { Posição na } \\
\text { pauta } \\
\text { Estadual }\end{array}$ \\
\hline 1999 & 19.895 & 31.19 & $1^{\circ}$ \\
\hline 2000 & 28.294 & 27.77 & $1^{\circ}$ \\
\hline 2001 & 23.199 & 16.68 & $1^{\circ}$ \\
\hline 2002 & 22.423 & 14.71 & $1^{\circ}$ \\
\hline 2003 & 31.725 & 14,45 & $1^{\circ}$ \\
\hline 2004 & 36.071 & 16,54 & $1^{\circ}$ \\
\hline 2005 & 30.500 & 14,67 & $1^{\circ}$ \\
\hline 2006 & 31.378 & 86,46 & $1^{\circ}$ \\
\hline 2007 & 40.877 & 79,28 & $1^{\circ}$ \\
\hline
\end{tabular}

Fonte: CONAB, 2008; AGROPOLOS, 2008. 
A produção de caju também vem se consolidando na Região Sudeste do país, ampliando suas áreas cultiváveis para além do Nordeste (EMBRAPA, 2003). Com a difusão e modernização das técnicas de produção do cajueiro "anão precoce" em substituição ao "comum", outros estados vêm interessando-se pela cultura, como Mato Grosso do Sul e São Paulo. Na região Noroeste do Estado de São Paulo, a empresa ASADA - Empreendimentos Agroindustriais Ltda. - localizada no município de Mirandópolis - introduziu a cultura do cajueiro em 1994, quando trouxe o primeiro lote de mudas enxertadas, produzidas no Ceará (PETINARI \& TARSITANO, 2002).

Além da produção de caju, o Estado de São Paulo produz, anualmente, cascas de amendoim, bagaço de cana-de-açúcar, palha de arroz, folhas e sabugo de milho; resíduos de suas principais culturas, os quais são fontes potenciais de cinzas que podem ser convertidos em adições minerais. Atualmente, o Estado de São Paulo é um dos maiores produtores potenciais de cinzas agroindustriais do país, uma vez que é responsável por um terço do PIB agroindustrial do Brasil (PORTAL DE INVESTIMENTOS, 2006).

O caju (Figura 3.1) é formado pelo pedúnculo (pseudofruto ${ }^{18}$ carnoso e duro, de cor amarela, alaranjada ou vermelha) e pelo fruto verdadeiro do cajueiro ${ }^{19}$, a castanha de caju (ou simplesmente castanha), de onde se extrai o principal produto de consumo, a amêndoa (PAIVA et al., 2000).

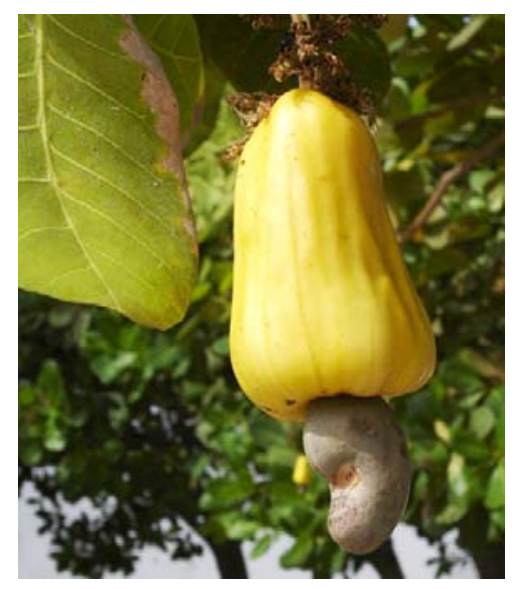

Figura 3.1 - Caju: pedúnculo (cor amarelada) e castanha (fruto verdadeiro). Fonte: Eric Gaba, 2005. Local: Euzébio, CE.

O processo de obtenção da amêndoa começa pela decorticação, ou seja, pela separação da amêndoa e da casca da castanha, que acontece em tanques com cardol. Este

\footnotetext{
${ }^{18}$ Ver Glossário.

19 Idem.
} 
é aquecido pelo calor gerado em caldeiras, ao passar por serpentinas numa temperatura de $800 \pm 5^{\circ} \mathrm{C}$. Os subprodutos dessa etapa são as amêndoas, de grande valor comercial, e as cascas encharcadas de cardol (Figura 3.2), que detêm grande potencial combustível. Comparativamente, o poder calorífico deste resíduo é equivalente ao de outros produtos utilizados para o mesmo fim, como a casca da semente de algodão, casca de amendoim, serragem e outros (SILVA et al., 2005).

Essas cascas, resíduos da produção, são incorporadas novamente ao processo e, nas caldeiras, irão gerar calor para decorticação de novas castanhas. A cinza é o resíduo colhido no fundo da grelha das caldeiras, resultante da queima das cascas, cujo resfriamento se faz lentamente. Atualmente, esse resíduo é utilizado como adubo em plantações de caju e, uma pequena parte, destinada a aterros sanitários comuns.

A cinza representa aproximadamente $5 \%$ do peso da castanha inicial ${ }^{20}$ e com a atual produtividade da cajucultura, a geração dessas cinzas pode chegar até 15.000 toneladas por ano.

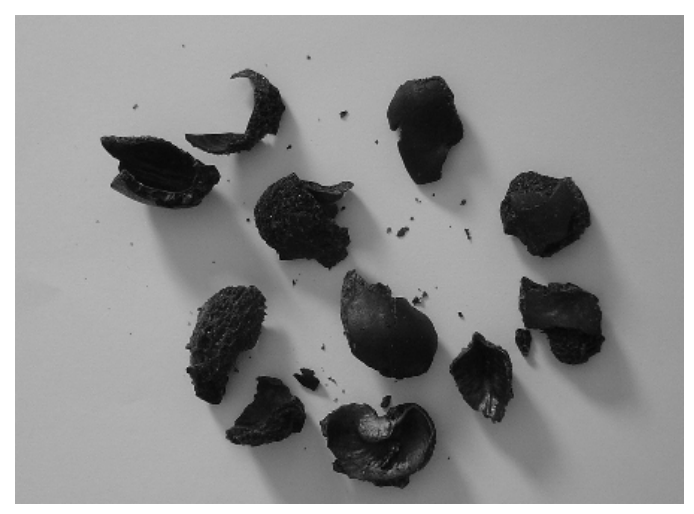

Figura 3.2 - Cascas de castanhas após decorticação:

bagaço de pedaços não-uniformes. Fonte: Silva, et al., 2005

Até o momento, porém, poucas pesquisas foram desenvolvidas com a cinza da casca da castanha do caju, mesmo que com fins diversos ao da construção civil. Uma delas procurou atestar os efeitos da adição da CCCC como adubo na produção de sorgo e de milho, obtendo resultados expressivos no florescimento da planta (ALMEIDA et al., 1988).

Outra pesquisa utilizou o resíduo da casca da castanha de caju, analisado como estabilizante de solos na produção de tijolos de terra crua, obtendo resultados pouco expressivos, estando sujeito, ainda, a estudos complementares (LIMA et al., 2004).

\footnotetext{
${ }^{20}$ Informação pessoal fornecida pela CIONE.
} 
$\mathrm{Na}$ bibliografia consultada não foram observadas pesquisas sobre o uso da cinza da casca da castanha de caju (CCCC) como adição mineral para concretos e argamassas.

Contudo, há uma possível potencialidade em relação ao uso da $\mathrm{CCCC}$, considerandose os resultados obtidos com outras cinzas de origem agroindustrial, segundo atesta Cincotto \& Kaupatez (1988), devido à expressiva quantidade de sílica em materiais orgânicos.

Análises preliminares de resistência à compressão em corpos-de-prova de argamassas, feitos por esta pesquisa, utilizando cimento CPV-ARI e CCCC, no teor de substituição de cimento de $5 \%$, no traço $1: 3$ e relação a/agl $=0,48$, demonstrou uma possível atividade pozolânica da cinza. $\mathrm{Na}$ idade de 56 dias os corpos-de-prova confeccionados com a cinza $(5 \%)$ apresentaram valores de resistência à compressão de 38,20MPa, enquanto nos corpos-de-prova sem adição foi observado o valor de 43,90MPa.

Cabe salientar, porém, que a cinza foi utilizada in natura, sem ter passado por processo de moagem. CYR et al. (2006), após vários estudos sobre as propriedades físicas das adições minerais, atestou que a finura do material influencia tanto durante as primeiras idades, pelo efeito filler ou pela nucleação heterogênea, como nas idades avançadas, quando os efeitos pozolânicos começam a ocorrer.

Essa cinza apresenta, adicionalmente, a vantagem de não necessitar de calcinação, em relação à possibilidade de aproveitamento como adição mineral, uma vez que é resultado final do processo de produção da amêndoa do caju. Esse fato a coloca em posição de vantagem sobre outras cinzas citadas anteriormente, haja vista que os processos de queima e calcinação demandam energia e geram gases que poluem o meio ambiente.

Mostra-se, na Tabela 3.2, a produção de alguns produtos agroindustriais e o respectivo volume de cinza gerado por cada um deles. Nota-se que a cinza da casca da castanha de caju possui maior volume de geração de cinzas (mais de 12.000 toneladas) quando comparadas com outras cinzas que, até o presente momento, foram pouco exploradas como adição mineral para materiais cimentícios. 
Tabela 3.2 - Subprodutos agrícolas: produção total e volume de cinzas gerado.

\begin{tabular}{lcccc}
\hline \multicolumn{1}{c}{ Produtos } & $\begin{array}{c}\text { Parte } \\
\text { utilizada }\end{array}$ & Calcinação * & $\begin{array}{c}\text { Produção } \\
\text { anual }(\mathrm{t})\end{array}$ & $\begin{array}{c}\text { Volume de } \\
\text { cinzas (t) }\end{array}$ \\
\hline CASTANHA DE CAJU & casca & não & $\mathbf{2 5 1 . 2 6 8 ( 1 )}$ & $\mathbf{1 2 . 5 6 2}$ \\
\hline Arroz & casca & não & $11.161 .688(2)$ & 446.468 \\
\hline Cana-de-açúcar & bagaço/palha & não & $442.236 .431(2)$ & 5.970 .192 \\
\hline Castanha-do-pará ** & casca & sim & $24.895(3)$ & sem dados \\
\hline Amendoim** & casca & sim & $265.355(2)$ & 2.388 \\
\hline Mamona** $^{\text {cam }}$ & casca & sim & $118.084(2)$ & 3.188 \\
\hline
\end{tabular}

$\left(^{*}\right)$ Refere-se à necessidade de calcinação do subproduto após finalização do processo industrial.

$\left({ }^{* *}\right)$ Produtos com pesquisa em fase preliminar ou insuficiente, a cerca da possibilidade de uso como adição mineral em produtos cimentícios.

1 - Produção total, Safra 2005. Fonte: Companhia Nacional de Abastecimento - CONAB.

2 - Produção total, Safra 2006. Fonte: Instituto Brasileiro de Geografia e Estatística - IBGE.

3 - Produção total, Safra 2006. Fonte: IBGE, Diretoria de Pesquisas, Coordenação de Agropecuária,

Produção da Extração Vegetal e da Silvicultura 2003.

No capítulo seguinte apresenta-se a metodologia desenvolvida para análise da CCCC como adição mineral para materiais cimentícios, buscando atender as seguintes assertivas:

- Expressiva quantidade de cinza gerada, anualmente, pelo processo de produção da amêndoa da castanha;

- Carência de pesquisas que enfoquem uma melhor utilização desse subproduto como adição mineral em produtos à base de cimento Portland;

- Necessidade da diminuição de emissão do $\mathrm{CO}_{2}$ no meio ambiente, buscando-se desta forma, alternativas a produção do clínquer;

- Os resultados das análises preliminares, explicitadas neste capítulo, que indicam a possibilidade de atividade pozolânica desse material.

Os ensaios propostos a seguir baseiam-se nas técnicas aplicadas às matrizes cimentícias tendo a CCCC como substituto parcial do cimento Portland. 


\section{Capítulo}

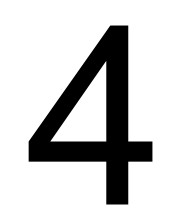

INVESTIGAÇÃO EXPERIMENTAL

De acordo com os objetivos especificados nos capítulos anteriores, e em acordo com a revisão da bibliografia, apresenta-se neste Capítulo, o programa experimental que tem o propósito de analisar a viabilidade do uso da cinza da casca da castanha de caju como adição mineral. A aplicação dessa metodologia pretende atender a grande parte das propriedades das matrizes cimentícias, desde a caracterização química, microestrutural, mecânica e, a depender do caso, a análise por meio de parâmetros ambientais.

Para tal, esta etapa de investigação experimental foi dividida em 5 (cinco) fases, a saber:

- $\quad 1^{a}$. Fase - Caracterização química e física;

- $\quad 2^{\mathrm{a}}$. Fase - Análise do potencial pozolânico;

- $\quad 3^{a}$. Fase - Análise da retração;

- $\quad 4^{a}$. Fase - Análise da profundidade de carbonatação;

- $\quad 5^{a}$. Fase - Determinação da capacidade de estabilização/solidificação de contaminantes pela matriz cimentícia.

A quinta fase de análises foi indicada pelos membros durante a banca de qualificação, tendo em vista os resultados obtidos por esta pesquisa até então. As análises experimentais contempladas em cada fase de estudos são apresentadas na Tabela 4.1. 
Tabela 4.1 - Resumo dos ensaios e a metodologia utilizada

\begin{tabular}{|c|c|c|c|}
\hline Etapas & Ensaios & Detalhes & $\begin{array}{l}\text { Metodologia/ } \\
\text { Equipamentos }\end{array}$ \\
\hline \multirow{8}{*}{$\begin{array}{l}\text { 1a Fase: } \\
\text { Caracterização } \\
\text { química e física }\end{array}$} & Análise química & $\begin{array}{l}\text { Amostra previamente solubilizada em } \\
\text { meio de fusão alcalina }\end{array}$ & $\begin{array}{l}\text { Análise quantitativa: } \\
\text { espectrômetro de } \\
\text { emissão ótica e } \\
\text { espectrofotômetro de } \\
\text { absorção atômica }\end{array}$ \\
\hline & Massa específica & Média de 2 ensaios consecutivos & NM 23/00 \\
\hline & Massa unitária & Média de 3 ensaios consecutivos & NBR $7251 / 82$ \\
\hline & Teor vítreo & 1 análise para amostra in natura & $\begin{array}{l}\text { Difratometria de raios } X \\
(\mathrm{Dr} X)\end{array}$ \\
\hline & $\begin{array}{c}\text { Superfície específica } \\
\text { BET }\end{array}$ & 1 análise & Absorção de nitrogênio \\
\hline & MEV & 1 análise & $\begin{array}{c}\text { Microscópio eletrônico } \\
\text { de varredura }\end{array}$ \\
\hline & Níveis de contaminação & $\begin{array}{c}1 \text { amostra in natura para cada } \\
\text { ensaio. }\end{array}$ & $\begin{array}{l}\text { NBR 10004, NBR } \\
10005 \text { e NBR } 10006\end{array}$ \\
\hline & $\begin{array}{l}\text { Avaliação do tempo } \\
\text { ótimo de moagem da } \\
\text { CCCC }\end{array}$ & $\begin{array}{c}\text { Análise de } 7 \text { traços; } 5 \text { amostras para } \\
\text { cada traço com o mesmo teor de } \\
\text { CCCC. }\end{array}$ & $\begin{array}{l}\text { Moinho de esferas } \\
\text { metálicas }\end{array}$ \\
\hline \multirow{4}{*}{$\begin{array}{l}2^{\text {a }} \text { Fase: Análise } \\
\text { do potencial } \\
\text { pozolânico }\end{array}$} & $\begin{array}{l}\text { Determinação o índice } \\
\text { de atividade pozolânica } \\
\text { com o cimento }\end{array}$ & 5 amostras; idade: 28 dias. & NBR 5752 \\
\hline & $\begin{array}{l}\text { Determinação o índice } \\
\text { de atividade pozolânica } \\
\text { com a cal }\end{array}$ & 3 amostras; idade: 7 dias. & NBR 5751 \\
\hline & $\begin{array}{l}\text { Variação do teor de } \\
\text { hidróxido de cálcio em } \\
\text { pastas }\end{array}$ & $\begin{array}{c}\text { Análise de } 8 \text { traços }(0 \%, 2.5 \%, 5 \% \\
7.5 \%, 10 \%, 15 \%, 20 \% \text { e } 30 \%) \text {; idade: } \\
100 \text { dias. }\end{array}$ & $\begin{array}{l}\text { Difratometria de raios } \mathrm{X} \\
\qquad(\mathrm{Dr} X)\end{array}$ \\
\hline & $\begin{array}{l}\text { Análise do teor de ótimo } \\
\text { de substituição da } \\
\text { CCCC em argamassas }\end{array}$ & $\begin{array}{c}\text { Análise de } 7 \text { traços }(0 \%, 2.5 \% \\
5 \%, 10 \%, 15 \%, 20 \% \text { e } 30 \%) \text {; idades: } \\
14,28,56 \text { e } 91 \text { dias. }\end{array}$ & $\begin{array}{l}\text { NBR } 5738, \text { NBR } 7214 \\
\text { e NBR } 7215\end{array}$ \\
\hline $\begin{array}{l}3^{\text {a }} \text { Fase: Análise } \\
\text { da retração }\end{array}$ & $\begin{array}{l}\text { Análise da retração por } \\
\text { secagem }\end{array}$ & $\begin{array}{c}3 \text { amostras por traço; idade: } 7,14 \\
28,56 \text { e } 119 \text { dias. }\end{array}$ & NBR 12650 \\
\hline
\end{tabular}

$4^{\mathrm{a}}$ Fase: Análise da profundidade de carbonatação
Análise da profundidade de carbonatação
1 traço para 2 amostras; idade: 90 e 180 dias.
Método colorimétrico

\section{$5^{\text {a }}$ fase:}

Determinação da capacidade de estabilização/ solidificação
Níveis de contaminação (extrato solubilizado)
Análise de 4 traços $(0 \%, 2.5 \%$, $5 \%, 10 \%$ ); idade: 28 dias.
NBR 10004 e NBR 10006 


\subsection{Materiais}

Os materiais utilizados na execução dos ensaios desta pesquisa encontram-se especificados a seguir.

\subsubsection{Cimento Portland}

Para os ensaios desta pesquisa utilizou-se o cimento Portland de alta resistência inicial, CP V ARI. As especificações foram fornecidas pelo fabricante, a empresa CIMINAS S.A. - Grupo Holdercim, e encontram-se nas Tabelas 4.2 e 4.3. O cimento CP V ARI provém de moagens diferenciadas do clínquer e adquire maiores resistências iniciais.

Esse tipo de cimento é muito utilizado em concretos para fabricação de pré-moldados, inclusive em elementos protendidos, o que resulta numa rápida reutilização dos moldes e maior produtividade.

Tabela 4.2 - Propriedades físicas - CPV ARI PLUS

\begin{tabular}{|c|c|c|c|}
\hline \multicolumn{2}{|c|}{ Características e propriedades } & Unidade & CPV ARI PLUS \\
\hline \multicolumn{2}{|c|}{ Massa específica (NBR 6474) } & $\mathrm{Kg} / \mathrm{dm}^{3}$ & 3,12 \\
\hline \multicolumn{2}{|c|}{ Massa unitária no estado solto (NBR 7251) } & $\mathrm{Kg} / \mathrm{dm}^{3}$ & 1,02 \\
\hline \multirow{3}{*}{ Finura } & Retido \# 200 (NBR 11579) & $\%$ & 0,20 \\
\hline & Retido \# 325 & $\%$ & 3,40 \\
\hline & Sup. Esp. Blaine (NBR 7224) & $\mathrm{cm}^{2} / \mathrm{g}$ & 4687 \\
\hline \multirow{2}{*}{ Tempo de pega } & (NBR 11581) & $\min$ & 130 \\
\hline & (NBR 11581) & $\min$ & 210 \\
\hline \multirow{4}{*}{$\begin{array}{l}\text { Resistência à compressão }\left(f_{\mathrm{cj}}\right) \\
\text { (NBR 7215) }\end{array}$} & 1 dia & $\mathrm{MPa}$ & 27,70 \\
\hline & 3 dias & $\mathrm{MPa}$ & 42,00 \\
\hline & 7 dias & $\mathrm{MPa}$ & 46,70 \\
\hline & 28 dias & $\mathrm{MPa}$ & 56,10 \\
\hline
\end{tabular}

Fonte: Fabricante. 
Tabela 4.3 - Composição química - CPV ARI PLUS

\begin{tabular}{cc}
\hline Constituintes & CPV ARI PLUS \\
\hline $\mathrm{SiO}_{2}(\%)$ & 19,65 \\
\hline $\mathrm{Al}_{2} \mathrm{O}_{3}(\%)$ & 4,99 \\
\hline $\mathrm{Fe}_{2} \mathrm{O}_{3}(\%)$ & 3,17 \\
\hline $\mathrm{CaO}(\%)$ & 64,03 \\
\hline $\mathrm{MgO}(\%)$ & 0,83 \\
\hline $\mathrm{K} \mathrm{O}(\%)$ & 0,69 \\
\hline $\mathrm{PF} 1000^{\circ} \mathrm{C}-\mathrm{NBR} 5743$ & 3,61 \\
\hline $\mathrm{CO}_{2}-\mathrm{NBR} 11583$ & 1,5 \\
\hline $\mathrm{RES} . \mathrm{INSO}^{\mathrm{N}} \mathrm{V}$ VEL - NBR 5744 & 0,88 \\
\hline $\mathrm{SO}_{3}-\mathrm{NBR} 5745$ & 2,56 \\
\hline
\end{tabular}

Fonte: Fabricante.

\subsubsection{Sílica ativa}

Nesta pesquisa utilizou-se sílica ativa (SA) proveniente da produção de ferro-silício, comercializada pela Elken-Microssílica Tecn Ind. e Com. Ltda, com massa específica no valor de $2,21 \mathrm{~g} / \mathrm{cm}^{3}$ e massa unitária igual a $0,20 \mathrm{~g} / \mathrm{cm}^{3}$.

As características físicas e químicas da sílica ativa são apresentadas nas Tabelas 4.4 e 4.5. A composição química foi realizada pelo Centro de Caracterização e Desenvolvimento de Materiais (CCDM) da Universidade Federal de São Carlos, de acordo com Silva (2006), e as demais características foram fornecidas pela Elken-Microssílica Tecn Ind. E Com. Ltda., atendendo às normas NBR 13956 (ABNT, 1997) e 13957 (ABNT, 1997).

Tabela 4.4 - Características físicas da sílica ativa

\begin{tabular}{cc}
\hline Diâmetro médio das partículas & $0,15 \mu \mathrm{m}$ \\
\hline Teor máximo de umidade & $3 \%$ \\
\hline$\%$ máxima retida \# 325 & $10 \%$ \\
\hline Área específica & $20 \mathrm{~m}^{2} / \mathrm{g}$ \\
\hline
\end{tabular}

Fonte: Fabricante 
Tabela 4.5 - Composição química da sílica ativa

\begin{tabular}{cc}
\hline Constituintes & sílica ativa (\%) \\
\hline $\mathrm{SiO}_{2}$ & 95,92 \\
\hline $\mathrm{Al}_{2} \mathrm{O}_{3}$ & traços \\
\hline $\mathrm{Fe}_{2} \mathrm{O}_{3}$ & 1,33 \\
\hline $\mathrm{CaO}$ & 0,36 \\
\hline $\mathrm{MgO}$ & 0,38 \\
\hline $\mathrm{K}_{2} \mathrm{O}$ & 0,30 \\
\hline $\mathrm{P}_{2} \mathrm{O}_{5}$ & $<\mathrm{LD}$ \\
\hline $\mathrm{MnO}$ & $<\mathrm{LD}$ \\
\hline $\mathrm{TiO}_{2}$ & 0,01 \\
\hline Perda ao fogo - PF & 1,58 \\
\hline LD - limite de detecção & Fonte: CCDM (Silva, 2006)
\end{tabular}

\subsubsection{Cal hidratada}

Utilizou-se para os ensaios a cal hidratada tipo $\mathrm{CH}$-III, marca Itaú, comercializada pela Votorantim Cimentos, com massa específica no valor de $2,30 \mathrm{~g} / \mathrm{cm}^{3}$ e massa unitária no estado solto igual a $0,50 \mathrm{~g} / \mathrm{cm}^{3}$. Segundo o fabricante, as especificações para os ensaios seguem as recomendações da norma NBR 7175 (ABNT, 2003). A composição química da cal utilizada encontra-se na Tabela 4.6.

Tabela 4.6 - Composição química da cal hidratada CH-III

\begin{tabular}{cc}
\hline Constituintes & Cal (\%) \\
\hline $\mathrm{CaO}$ & 54 \\
\hline $\mathrm{MgO}$ & 16 \\
\hline $\mathrm{SiO}_{2}$ & 2,7 \\
\hline outros & 5 \\
\hline $\mathrm{PF}$ & 26 \\
\hline
\end{tabular}

Fonte: Fabricante.

\subsubsection{Agregado miúdo}

Foi utilizada a areia normal do IPT, segundo as recomendações da norma NBR 7214 (ABNT, 1982), para execução dos ensaios desta pesquisa. 


\subsubsection{Cinza da casca da castanha de caju}

A cinza utilizada foi cedida pela empresa CIONE - Companhia Industrial de Óleos do Nordeste, localizada em Fortaleza - CE, disposta em sacos lacrados de faces aluminizadas. As amostras utilizadas nesta pesquisa foram coletadas de acordo com a NBR 10007 (ABNT, 2004).

\subsection{Métodos}

De acordo com os objetivos deste trabalho, apresentam-se os procedimentos metodológicos utilizados para a análise da viabilidade do uso da cinza da casca da castanha de caju como adição mineral em matrizes cimentícias.

\subsubsection{Análise química}

O método utilizado para análise química foi a de análise quantitativa. A amostra foi solubilizada em meio de fusão alcalina e os elementos determinados em espectrômetro de emissão ótica com plasma induzido, modelo VISTA, da marca Varian, exceto para potássio e silício, que foram determinados em espectrofotômetro de absorção atômica com chama, modelo Spectra A 640, da marca Varian (IT AQ-158 revisão 009). Para essa análise, a amostra foi obtida a partir da CCCC seca em estufa a $100^{\circ} \mathrm{C}$, por $12 \mathrm{~h}$, e posteriormente moída durante 8 horas em moinho de esferas metálicas.

As características principais do moinho utilizado para a moagem da CCCC são: i) volume interno do moinho: 6,8 litros; ii) velocidade de rotação: 132 rotações/minuto; iii) número de esferas: 12; iv) massa de cada esfera: 170 gramas; v) quantidade de CCCC utilizada em cada moagem: 700 gramas de material seco.

O laudo da análise química foi emitido pelo Centro de Caracterização e Desenvolvimento de Materiais - CCDM, da Universidade Federal de São Carlos, sob o número AQ06-000193. 


\subsubsection{Determinação da massa unitária e da massa específica}

Para efeitos de dosagem considera-se importante conhecer o volume ocupado pelas partículas dos materiais constituintes dos concretos e argamassas. Por ser a CCCC um resíduo não estudado anteriormente como adição mineral, considerou-se necessária a determinação da massa específica e unitária desse material, para sua correta aplicação em matrizes cimentícias.

O ensaio de massa unitária da CCCC foi executado em acordo com a NBR 7251 (ABNT, 1982). A única alteração deu-se em relação ao recipiente, que nesta pesquisa foi alterado para 3,00 litros, diferentemente do que a norma exige. Essa mudança foi necessária devido a característica da CCCC, já que não se trata de um agregado, e sim, de um material pulverulento.

O ensaio de massa específica da CCCC foi realizado seguindo as recomendações da norma NM 23 (MERCOSUR, 2000), utilizando como líquido o querosene e $45 \mathrm{~g}$ de material seco in natura.

\subsubsection{Análise dos extratos lixiviado e solubilizado da CCCC in natura}

Nas análises de lixiviação e solubilização das amostras de CCCC foram determinados possíveis contaminantes e/ou metais pesados contidos no material. Tais dados apresentamse de grande relevância na avaliação da necessidade de encapsulamento do material pela técnica de estabilização/solidificação, bem como em relação aos cuidados específicos no pós-tratamento desse resíduo.

O ensaio foi executado pelo Laboratório de Saneamento da Escola de Engenharia de São Carlos (EESC/USP), seguindo as especificações das normas NBR 10004, NBR 10005, NBR 10006 e 10007 (ABNT, 2004).

\subsubsection{Determinação da superfície específica - método BET}

Foi escolhido o método BET (Brunauer-Emmet-Teller) para análise da superfície específica da CCCC. O ensaio foi realizado no Departamento de Engenharia Química da Universidade Federal de São Carlos. A amostra passou por moagem em moinho de bolas metálicas durante 1 (uma) hora. 


\subsubsection{Análise por Microscopia Eletrônica de Varredura - MEV}

Por possibilitar a análise semiquantitativa e quantitativa dos elementos presentes em uma amostra, a técnica de Microscopia Eletrônica de Varredura - MEV foi empregada na análise das partículas da CCCC. As imagens foram feitas no Laboratório de Microscopia Eletrônica do Instituto de Física de São Carlos da Universidade de São Paulo. A amostra passou por moagem em moinho de bolas metálicas durante 1 (uma) hora.

\subsubsection{Análise por Difratometria de raios $X$}

Alguns materiais contendo vidro silicoso apresentam um halo centrado em torno de $22^{\circ} 2 \theta$, a posição exata vai depender da natureza do mesmo. A esse halo podem estar sobrepostos picos de diferentes formas cristalinas da sílica, como o quartzo $\left(26,6^{\circ}\right.$ e $\left.20,8^{\circ} 2 \theta\right)$, a cristobalita $\left(21,9^{\circ} 2 \theta\right)$, entre outros (JOHN et al. , 2003).

A técnica de difratometria de raios $\mathrm{X}(\mathrm{DrX})$ possui caráter qualitativo e/ou quantitativo, baseando-se na identificação das fases cristalinas presentes no material analisado. $O$ estudo dos picos presentes no difratograma por comparação com bancos de dados específicos permite avaliação sobre o quanto uma amostra é amorfa ou cristalina, como também sua comparação, de forma qualitativa, com outros materiais de mesma natureza.

A análise do tipo qualitativa apresenta-se como uma técnica útil, não só na caracterização dos materiais de construção civil minerais, identificando-os, como também no acompanhamento de todas as transformações ocorridas ao longo do tempo, sejam de desenvolvimento de suas propriedades, ou as resultantes de deterioração ${ }^{21}$.

A técnica de Difratometria de raios $X(\operatorname{DrX})$ foi utilizada na análise da amostra de CCCC in natura e de 15 pastas com idade de 100 dias descritas (Tabela 4.7). As análises foram realizadas no Laboratório Cristalografia de Raios $X$ do Instituto de Física de São Carlos da Universidade de São Paulo.

${ }^{21}$ Cincotto, M. A. (2007). Análise por difração de raios X. Nota de aula da disciplina "Aglomerantes de argamassas e concretos". PCC/EPUSP. 
Tabela 4.7 - Dados para análise de pastas por DrX

\begin{tabular}{lccccccccccccccc}
\hline Pastas * & $\mathbf{1}$ & $\mathbf{2}$ & $\mathbf{3}$ & $\mathbf{4}$ & $\mathbf{5}$ & $\mathbf{6}$ & $\mathbf{7}$ & $\mathbf{8}$ & $\mathbf{9}$ & $\mathbf{1 0}$ & $\mathbf{1 1}$ & $\mathbf{1 2}$ & $\mathbf{1 3}$ & $\mathbf{1 4}$ & $\mathbf{1 5}$ \\
\hline $\mathrm{SA}(\%)$ & - & 2,5 & 5,0 & 7,5 & 10,0 & 15,0 & 20,0 & 30,0 & - & - & - & - & - & - & - \\
\hline $\mathrm{CCCC}(\%)$ & - & - & - & - & - & - & - & - & 2,5 & 5,0 & 7,5 & 10,0 & 15,0 & 20,0 & 30,0 \\
\hline
\end{tabular}

* SA - sílica ativa / CCCC - cinza da casca da castanha de caju

Utilizou-se um difratômetro de raios $X$ da marca RIGAKU ROTAFLEX, modelo RU200B. As condições para realização das análises foram: i) radiação: $\mathrm{Cu} K \alpha$; ii) tensão: $50 \mathrm{Kv}$; iii) corrente: $100 \mathrm{~mA}$; iv) varredura com passo de $0,02^{\circ} 2 \theta$; v) tempo de coleta: $2^{\circ} / \mathrm{min}$; vi) intervalo de varredura: 3 a $100^{\circ}(2 \theta)$.

Para a moldagem das pastas foram utilizados corpos-de-prova cilíndricos de 25x50mm, conforme Figura 4.1. Os materiais utilizados foram: cimento Portland CP V ARI, sílica ativa (SA) e CCCC em teores variados, conforme Tabela 4.7. A relação água/agl foi mantida constante para todos os traços, no valor de 0,36. A CCCC utilizada nesse ensaio foi moída durante 1 hora no moinho de bolas e peneirada (material passante na peneira $\left.n^{\circ} 200\right)$.

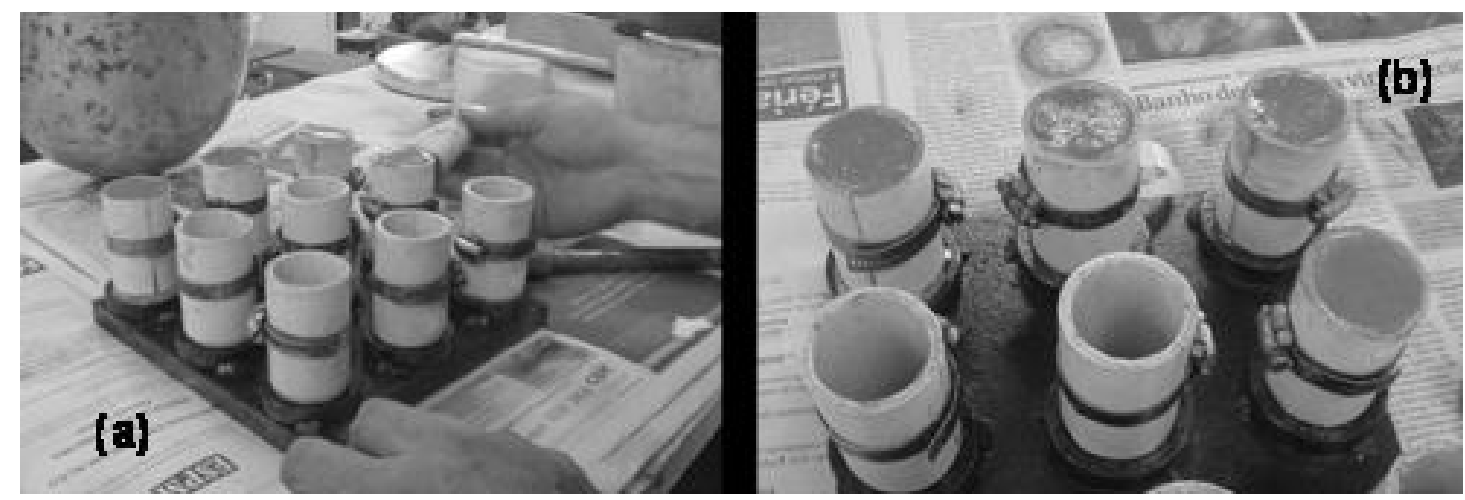

Figura 4.1 - (a) Corpos-de-prova 50x25mm. (b) Moldagem dos diferentes traços.

Após a moldagem, os corpos-de-prova permaneceram em câmara seca com temperatura controlada $\left(23^{\circ} \mathrm{C} \pm 2^{\circ} \mathrm{C}\right)$ dentro das formas. Foram desmoldados aos 28 dias, permanecendo no mesmo local até o $100^{\circ}$ dia. Ao final desse período, os corpos-de-prova foram rompidos ao meio, fragmentados e moídos, utilizando-se almofariz cerâmico (Figura 4.2). O pó resultante foi passado na peneira $\mathrm{n}^{\circ} 200$ - abertura $0,075 \mathrm{~mm}$ - (Figura 4.2) sendo coletado o material passante. 


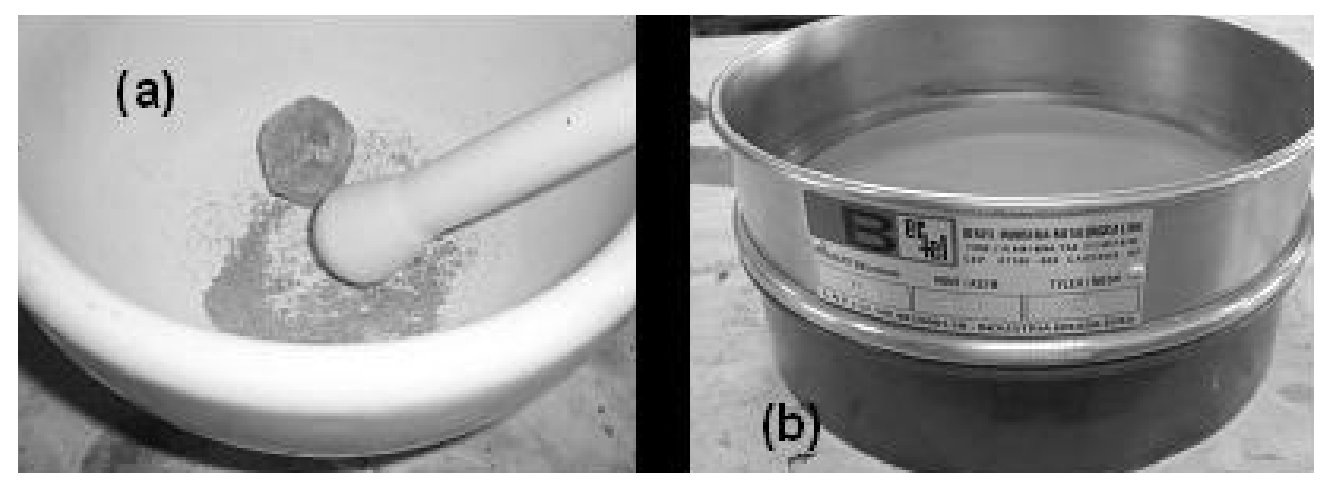

Figura 4.2 - (a) Fragmento de amostra no almofariz cerâmico. (b) Peneira $n^{\circ} 200$.

As amostras foram armazenadas em porta-amostras e submetidas à análise de difratometria de raios $\mathrm{X}$.

\subsubsection{Análise do tempo ótimo de moagem da CCCC}

Com o objetivo de avaliar a influência do tamanho dos grãos da CCCC na sua reatividade com o cimento Portland, essa etapa de ensaios determinou 7 (sete) tempos de moagem (Tabela 4.8) e posteriormente, analisou tais amostras em corpos-de-prova de argamassa, analisando, ao final, a evolução da resistência mecânica dos mesmos.

Executou-se paralelamente, ensaio de peneiramento como método de determinação do tamanho dos grãos da CCCC pós-moagem, nos 7 tempos descritos na Tabela 4.8. $O$ peneiramento das amostras foi executado segundo a NBR 11579 (ABNT, 1991), para peneiras $\mathrm{n}^{\circ} 200$ (abertura $0,075 \mathrm{~mm}$ ). Foi repetido o mesmo procedimento para a peneira de $n^{\circ} 250$, uma vez que esta não possui norma específica.

Tabela 4.8 - Dados referentes ao ensaio de avaliação do tempo ótimo de moagem

\begin{tabular}{|c|c|c|c|c|}
\hline \multirow{2}{*}{ Amostra } & \multirow{2}{*}{$\begin{array}{c}\text { Tempos de } \\
\text { moagem (CCCC) }\end{array}$} & \multicolumn{2}{|c|}{$\mathrm{n}^{\circ}$ corpos-de-prova } & \multirow{2}{*}{ Total } \\
\hline & & 28 dias & 91 dias & \\
\hline 0 & - & 5 & 5 & 10 \\
\hline 1 & 15 minutos & 5 & 5 & 10 \\
\hline 2 & 30 minutos & 5 & 5 & 10 \\
\hline 3 & 1 hora & 5 & 5 & 10 \\
\hline 4 & 2 horas & 5 & 5 & 10 \\
\hline 5 & 4 horas & 5 & 5 & 10 \\
\hline 6 & 10 horas & 5 & 5 & 10 \\
\hline 7 & 20 horas & 5 & 5 & 10 \\
\hline
\end{tabular}


O ensaio teve início com a preparação das amostras, as quais foram secas em estufa, na temperatura de $100 \pm 5^{\circ} \mathrm{C}$, durante 24 horas, em porções de $700 \mathrm{~g}$. Depois de retirado da estufa, o material foi posto no moinho de esferas metálicas e moído por diferentes tempos (Figura 4.3).

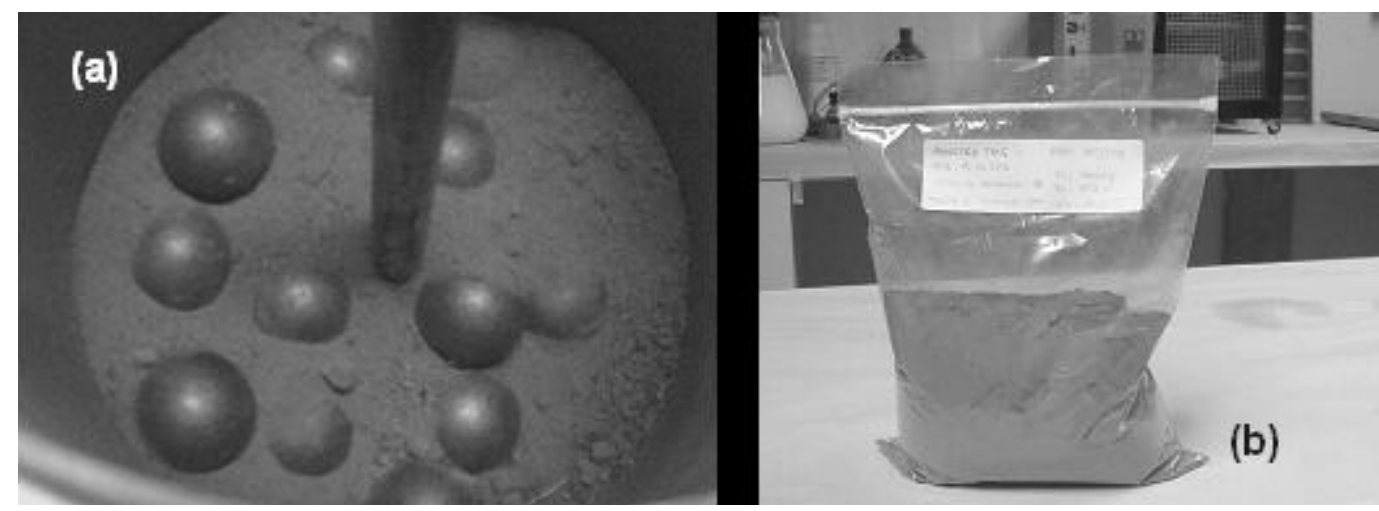

Figura 4.3 - (a) Amostra de CCCC no moinho de esferas metálicas. (b) Amostra de CCCC embalada e identificada.

Após moagem e peneiramento, seguiram-se as moldagens dos corpos-de-prova de argamassa. Essa etapa consistiu na moldagem de uma amostra contendo 5 (cinco) corposde-prova para cada traço. Cada amostra foi moldada utilizando um dos 7 (sete) tempos de moagem (Tabela 4.8), e posteriormente submetidas a análise de resistência mecânica aos 28 e 91 dias cada, seguindo os procedimentos da NBR 7215 (ABNT, 1996). Foram utilizados os teores de cimento e CCCC propostos pela NBR 5752 (ABNT, 1992).

A etapa de moldagem dos corpos-de-prova começou com a determinação da consistência da argamassa (trabalhabilidade de referência) por meio do ensaio de espalhamento (flow table test) (Figura 4.4). Segundo a NBR 5752 (ABNT, 1992), o valor do espalhamento da argamassa não poderia ser inferior a $220 \mathrm{~mm}$ nem superior a $230 \mathrm{~mm}$.

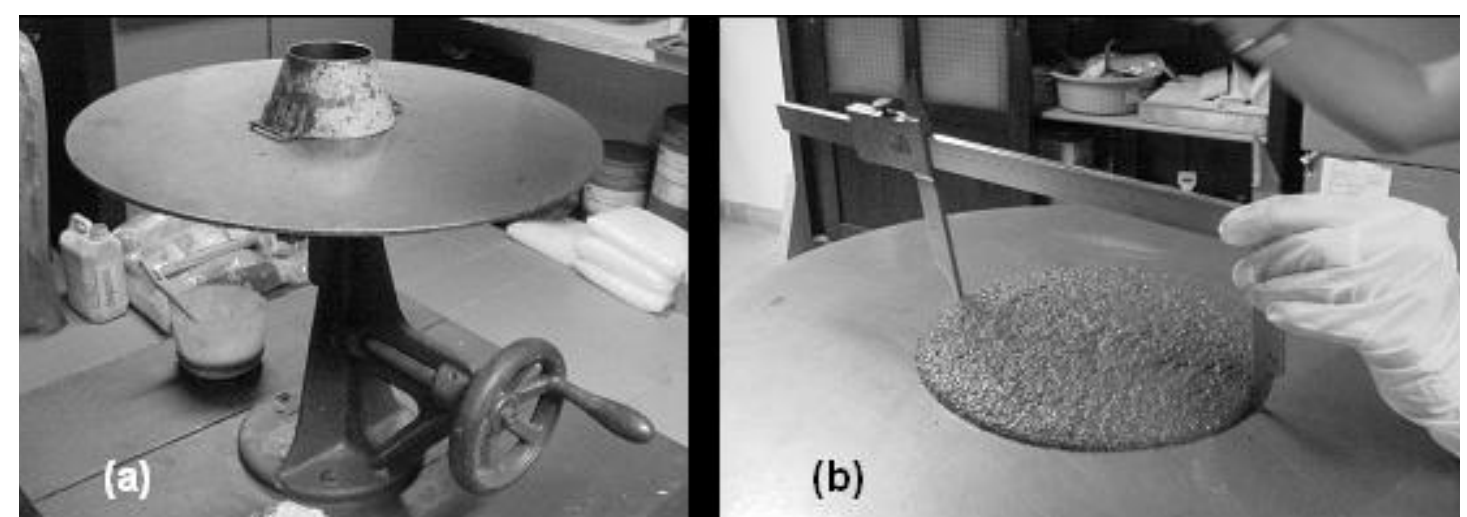

Figura 4.4 - (a) Mesa para o Flow Test. (b) Medição do espalhamento da argamassa com paquímetro. 
Os corpos-de-prova da amostra de referência (amostra 0) foram confeccionados no traço 1:3 com cimento CP V ARI PLUS e areia normal do IPT, segundo as normas NBR 7215 (ABNT, 1996) e 5752 (ABNT, 1992). Os corpos-de-prova das amostras 1 a 7 foram confeccionados também com areia normal do IPT, no traço de $65 \%$ de cimento $+35 \%$ da adição utilizada, no caso a CCCC, corrigida pela massa específica da CCCC em relação a do cimento em substituição, segundo a NBR 5752 (ABNT, 1992), especificados na Tabela 4.9 .

Tabela 4.9 - Quantidade de material. Moldagem dos corpos-de-prova

\begin{tabular}{ccc}
\hline Material ${ }^{1}$ & Traço A & Traço B \\
\hline Cimento Portland & $1.250,00 \mathrm{~g}$ & $812,50 \mathrm{~g}$ \\
\hline CCCC & - & $437,50 \times \mathrm{F}=312,70 \mathrm{~g}$ \\
\hline Areia normal & $3.750,00 \mathrm{~g}$ & $3.750,00 \mathrm{~g}$ \\
\hline $\begin{array}{l}\text { 1 } \text { material necessário para moldagem de 10 corpos-de-prova de } 50 \times 100 \mathrm{~mm} \\
\text { (LCC/EESC/USP) }\end{array}$ \\
Traço A - cimento Portland + Areia normal (1:3) \\
Traço B - 65\% cimento Portland + 35\% CCCC (corrigido) + Areia normal \\
\hline
\end{tabular}

Fonte: NBR 5752/92

Sendo o fator de correção F, calculado pela expressão:

$$
\mathrm{F}=\frac{\rho(\mathrm{CCCC})}{\rho(\mathrm{CP})}
$$

Onde:

$\rho(\mathrm{CCCC})=$ massa específica da $\operatorname{CCCC}^{22}=2,23 \mathrm{~g} / \mathrm{cm}^{3}$

$\rho(\mathrm{CP})=$ massa específica do cimento CP ARI PLUS $=3,12 \mathrm{~g} / \mathrm{cm}^{3}$

Após a moldagem (Figura 4.5) os corpos-de-prova permaneceram em câmara seca de temperatura controlada $\left(23 \pm 2^{\circ} \mathrm{C}\right)$, desmoldados com $24 \mathrm{~h}$, capeados com pasta de cimento, e permaneceram em câmara úmida até a data da ruptura, aos 28 e 91 dias.

\footnotetext{
${ }^{22}$ À época do ensaio de tempo de moagem a Massa Específica da CCCC já havia sido determinada por esta pesquisa.
} 

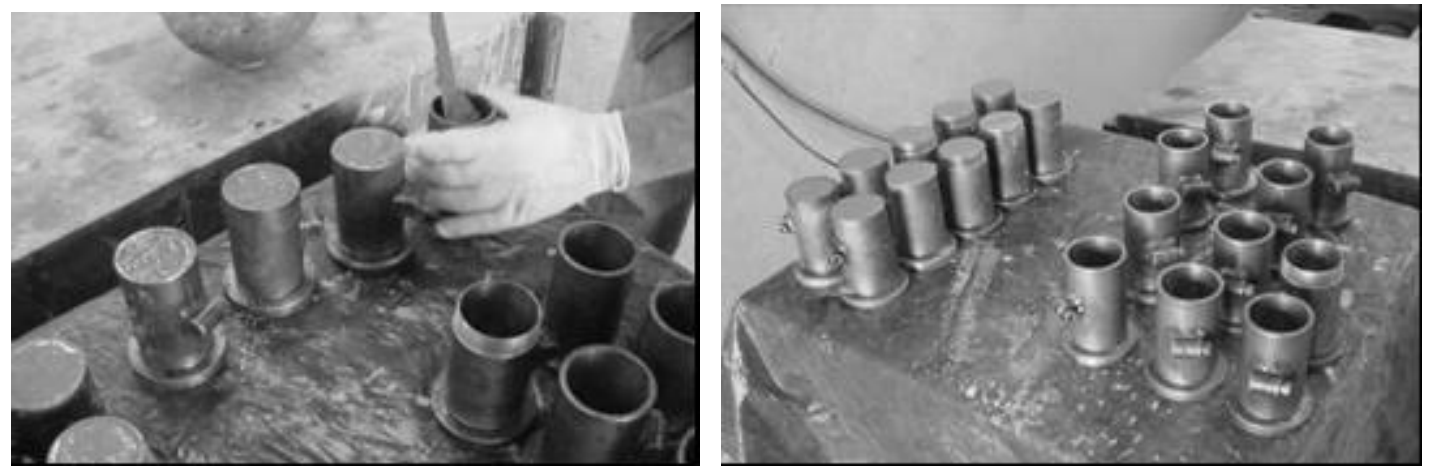

Figura 4.5 - Moldagem dos corpos-de-prova de argamassa.

\subsubsection{Análise da pozolanicidade com o cimento Portland}

Para esse ensaio foram moldados 3 (três) grupos com 3 corpos-de-prova cada, denominados grupo PADRÃO, grupo A e grupo $B$, respectivamente, segundo as NBR 7215 (ABNT, 1996) e 5752 (ABNT, 1992). A indicação dos traços e o pré-tratamento dado a CCCC se encontram na Tabela 4.10.

Neste ensaio foram aplicados dois tipos de tratamentos distintos à CCCC. Para a moldagem da amostra A, a cinza passou apenas por 1 (uma) hora de moagem no moinho de bolas (Figura 4.8a). Para a amostra B a cinza foi moída e posteriormente peneirada, sendo recolhido o material passante na peneira $n^{\circ} 200$ (abertura $0,075 \mathrm{~mm}$ ), a qual foi utilizado para esse ensaio.

Tabela 4.10 - Traços - Ensaio pozolanicidade com cimento Portland

\begin{tabular}{cccc}
\hline & Padrão & A & B \\
\hline Cimento & 1 & 0,65 & 0,65 \\
\hline Areia normal IPT & 3 & 3 & 3 \\
\hline CCCC $^{*}$ & --- & 0,35 & 0,35 \\
\hline $\begin{array}{c}\text { Tratamento } \\
\text { CCCC }\end{array}$ & --- & Moagem & $\begin{array}{c}\text { Moagem + } \\
\text { peneiramento }\end{array}$ \\
\hline
\end{tabular}

* quantidade de CCCC corrigida, segundo a norma 5752 (eq. 2, pág 72). Fonte: NBR 5752/92

Os materiais utilizados para essa análise encontram-se ilustrados na Figura 4.6. 


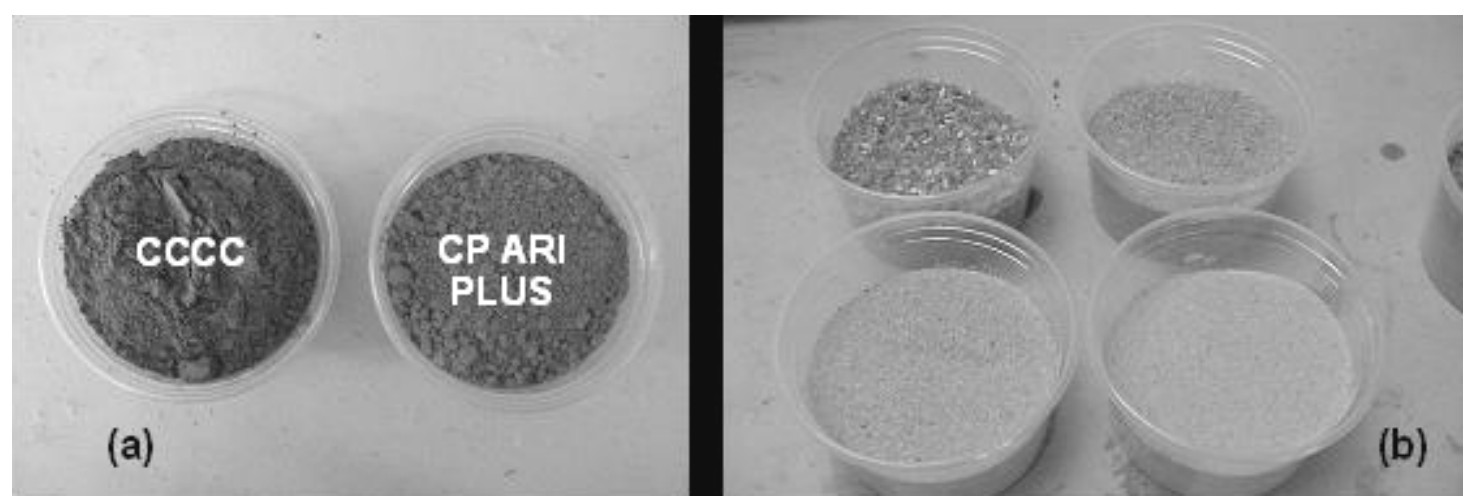

Figura 4.6 - Materiais utilizados - (a) Amostra de CCCC e CP ARI PLUS. (b) Quarteamento da areia normal do IPT, segundo NBR 7214.

Logo após a moldagem, ainda nos moldes, os corpos-de-prova cilíndricos foram colocados em câmara úmida à temperatura de $23 \pm 2^{\circ} \mathrm{C}$, durante $24 \pm 2 \mathrm{~h}$, com as faces superiores expostas ao ar úmido porém protegidas de respingos de água. Após a desmoldagem, foram mantidos em estufa (Figura 4.7) a uma temperatura de $38 \pm 2^{\circ} \mathrm{C}$ durante 27 dias, após os quais foram resfriados, capeados com enxofre e submetidos ao ensaio de resistência à compressão.

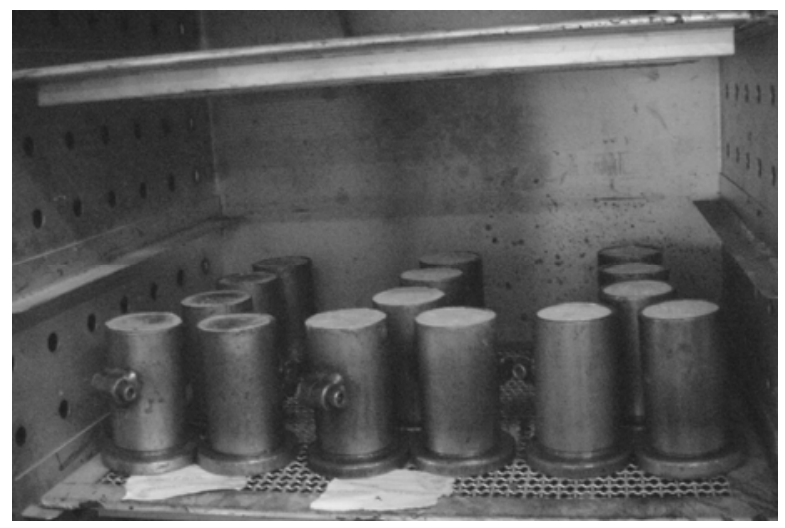

Figura 4.7 - Corpos-de-prova mantidos em estufa por 27 dias.

\subsubsection{Análise da pozolanicidade com a cal}

Para esse ensaio foram moldados 2 (dois) grupos com 3 corpos-de-prova cada, denominados grupo A e grupo $B$, respectivamente, segundo as NBR 7215 (ABNT, 1996) e 5751 (ABNT, 1992). A indicação dos traços e o pré-tratamento dado a CCCC se encontram na Tabela 4.11. 
Tabela 4.11 - Proporção dos materiais utilizados no ensaio de pozolanicidade com a cal

\begin{tabular}{ccc}
\hline & Grupo A & Grupo B \\
\hline Cal hidratada & 1 & 1 \\
\hline Areia normal IPT & 9 & 9 \\
\hline CCCC $^{*}$ & 2 & 2 \\
\hline $\begin{array}{c}\text { Tratamento } \\
\text { CCCC }\end{array}$ & Moagem & $\begin{array}{c}\text { Moagem + } \\
\text { peneiramento }\end{array}$ \\
\hline
\end{tabular}

Fonte: NBR 5751/92

A quantidade $Q$ de CCCC foi calculada segundo a norma NBR 5751, pela seguinte expressão:

$$
\mathrm{Q}_{\mathrm{CCCC}}=\frac{\rho(\mathrm{CCCC})}{\rho(\mathrm{CAL})}
$$

Onde:

$\rho(\operatorname{CCCC})=$ massa específica da CCCC $=2,23 \mathrm{~g} / \mathrm{cm}^{3}$

$\rho(\mathrm{CAL})=$ massa específica da cal hidratada, fornecida pelo fabricante $=2,30 \mathrm{~g} / \mathrm{cm}^{3}$

O teor de água foi determinado, assim como no ensaio com o cimento portland, pela determinação da consistência da argamassa (trabalhabilidade de referência) por meio do ensaio de espalhamento (flow table test - Figura 4.3). A cura dos corpos-de-prova foi realizada nos próprios moldes durante 7 (sete) dias, tendo esses sido mantidos vedados para evitar a perda de umidade (Figura 4.8).

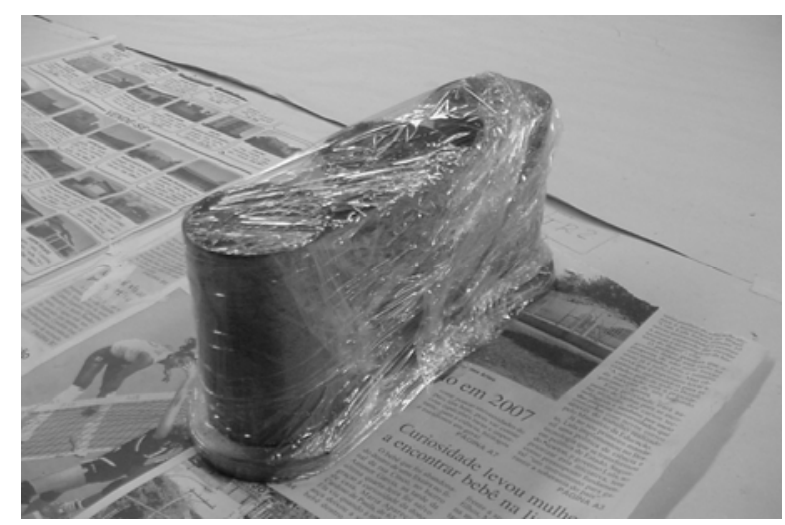

Figura 4.8 - Cura dos corpos-de-prova nas primeiras $24 \mathrm{~h}$ em câmara seca de temperatura controlada

Durante as primeiras $24 \pm 2 \mathrm{~h}$, os corpos-de-prova permaneceram a uma temperatura de $23 \pm 2^{\circ} \mathrm{C}$ em câmara seca com temperatura controlada; e durante as $144 \pm 2 \mathrm{~h}$ posteriores, os corpos-de-prova foram mantidos a um a temperatura de $55 \pm 2^{\circ} \mathrm{C}$ em estufa 
até o momento do ensaio de ruptura à compressão, segundo norma NBR 5751 (ABNT, 1992).

\subsubsection{Análise do teor ótimo de substituição da CCCC}

A influência da variação dos teores de substituição do cimento Portland pela CCCC foi analisada segundo o ensaio de resistência à compressão em corpos-de-prova de argamassa. Por esse ensaio, foi possível avaliar o teor ótimo de aplicação da CCCC pelo qual as propriedades mecânicas das matrizes cimentícias possam ser mantidas.

Para esse ensaio foram moldados 2 (dois) grupos com 6 (seis) traços cada, apresentados na Tabela 4.12. O Grupo A corresponde aos traços confeccionados com teores variados de CCCC moída (durante 1 hora no moinho de bolas) e peneirada (material passante na peneira $\mathrm{n}^{\circ} 200$ - abertura $0,075 \mathrm{~mm}$ ) de 2,5 a $30 \%$. O mesmo tratamento e condições se referem às amostras do Grupo $B$, no entanto, nesse grupo a CCCC não passou por peneiramento.

Todas essas amostras foram ensaiadas aos 14, 28, 56 e 91 dias para determinação da resistência à compressão axial.

Tabela 4.12 - Traços e Idades de ruptura - Ensaio de teores de substituição

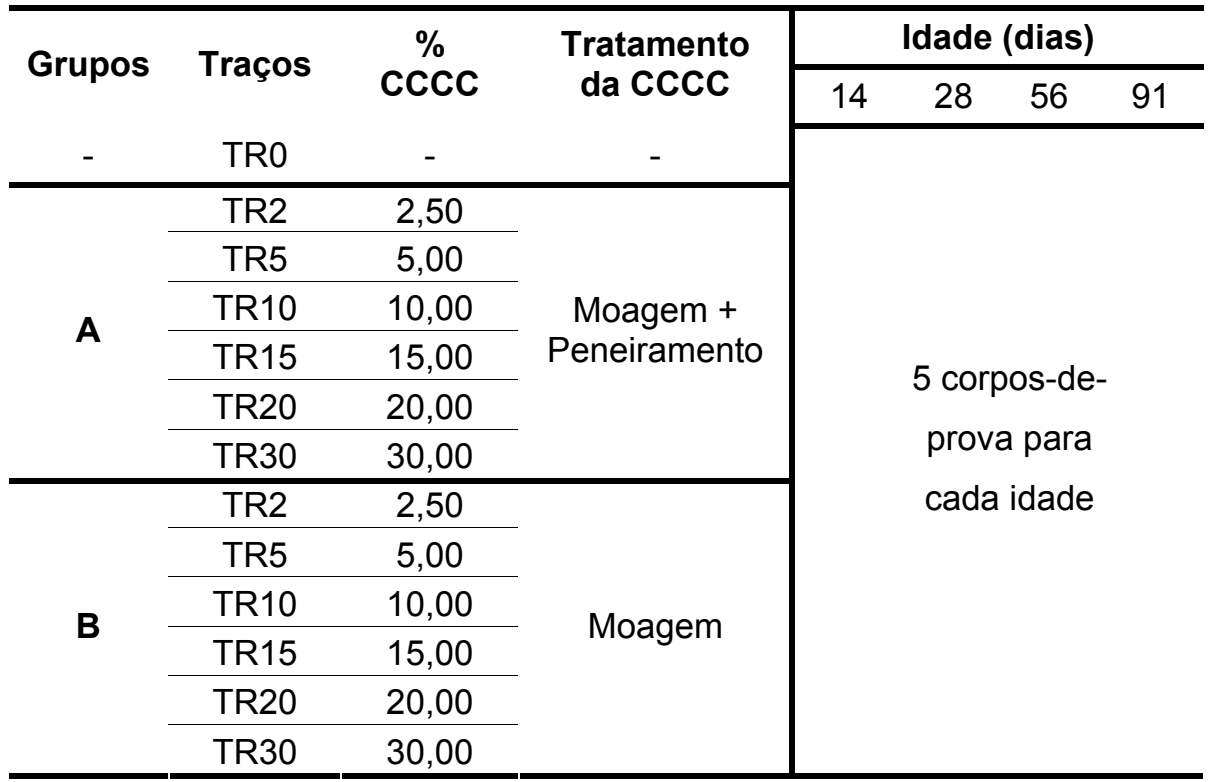


Como forma de melhor avaliar esses dados, utilizou-se a inferência estatística pelo Teste T de Student, apresentada em detalhes no Apêndice A. Com essa ferramenta foi possível determinar se os valores das médias das resistências das amostras dos Grupos $A$ e $B$ são estatisticamente iguais à média do traço padrão, denominado TR0, ainda que esses se apresentem em valores distintos.

Para as moldagens foram utilizados corpos-de-prova cilíndricos de 50x100mm, cimento Portland CP V ARI PLUS e areia normal do IPT, no traço 1:3. O teor de água foi determinado pelo índice de consistência (flow table test, Figura 4.4) entre 220 e $230 \mathrm{~mm}$, segundo norma NBR 5752 (ABNT, 1992).

Paralelamente a esse ensaio, foram determinadas as massas específicas no estado fresco das argamassas, segundo a norma NBR 13278 (ABNT, 1995). Tais dados são importantes para a análise da evolução das resistências mecânicas das amostras, uma vez que uma maior incorporação de ar acarreta numa maior porosidade da matriz afetando diretamente a resistência mecânica da mesma (MEHTA \& MONTEIRO, 1994).

\subsubsection{Análise estatística}

A análise estatística foi realizada utilizando funções do software Excel, da Microsoft, e empregada como ferramenta para subsidiar as comparações entre as médias da amostra PADRÃO e daquelas que utilizaram a CCCC no ensaio de resistência à compressão.

O Teste $\mathrm{T}$ de Student foi utilizado para testar se duas amostras pequenas ${ }^{23}$ pertencem a uma mesma população, aceitando-se ou não a hipótese de igualdade entre os resultados analisados. O nível de significância adotado foi de 5\% (cinco por cento). Essa porcentagem indica que são considerados diferentes os grupos cuja significância seja menor que este valor. A justificativa da escolha desse teste estatístico, bem como os conceitos utilizados por esta pesquisa, encontram-se melhor detalhados no Apêndice A.

${ }^{23}$ Amostra pequena - amostra menor que 30 observações. Uma amostra é um subconjunto de observações selecionadas a partir de uma população (MONTGOMERY \& RUNGER, 2003). 


\subsubsection{Análise da retração por secagem de materiais pozolânicos}

A saída da água da matriz de cimento conservado em ar não saturado causa a retração hidráulica, ou por secagem (NEVILLE, 1997).

Segundo Melo Neto (2002), a retração por secagem ocorre após o fim da pega, devido a redução dimensional causada pela evaporação da água de poro da matriz cimentícia. Em ambientes abaixo de $100 \%$, ocorre a perda de água da matriz e a conseqüente retração (POWERS, $1968^{24}$ apud MELO NETO, 2002).

Associada a retração por secagem, ocorre a retração autógena definida como a "diminuição do volume sob temperatura constante, e sem perda de umidade da matriz cimentícia para o meio ambiente, causada pela redução da umidade relativa no interior dos poros em decorrência da evolução na hidratação do cimento". Esse mecanismo também é conhecido como auto-secagem (POWERS, $1968^{25}$ apud MELO NETO, 2002).

Sendo assim, a retração por secagem e a retração autógena são causadas, principalmente pelo mecanismo de tensão capilar. A causa da retração por secagem é a perda de água para o meio ambiente, e da retração autógena para as reações do cimento (MELO NETO, 2002).

Para entender como se procede a retração por secagem em argamassas com substituição de cimento Portland por $\mathrm{CCCC}$, foram analisados corpos-de-prova prismáticos (40x40x160mm) divididos em 3 (três) diferentes grupos.

O Grupo A corresponde aos traços estabelecidos pela norma NBR 12650 (ABNT, 1992), onde parte da areia utilizada no traço denominado $P$ (amostra referência) é substituída pelo material pozolânico em questão, criando-se o traço N (amostra teste).

Complementarmente aos traços exigidos por norma, foram propostos outros dois. As amostras do grupo denominado "Grupo B" foram confeccionadas com teores de CCCC entre 2,5 e $30 \%$, sendo essa moída durante 1 hora no moinho de bolas. As do "Grupo C" obtiveram o mesmo tratamento do grupo anterior, com a diferença de que a CCCC foi passada na peneira $\mathrm{n}^{\circ} 200$ (abertura $0,075 \mathrm{~mm}$ ), após a moagem, sendo utilizado apenas 0

\footnotetext{
${ }^{24}$ POWERS, T. C. (1968). The thermodynamics of volume change and creep. Matériaux et Constructions. v. 1 , n. 6, p. 487-507.

${ }^{25}$ Idem.
} 
material passante. Todos os traços utilizados para esse ensaio encontram-se detalhados na Tabela 4.13.

Tabela 4.13 - Dados para moldagem dos corpos-de-prova em argamassa - ensaio de retração

\begin{tabular}{cccccc}
\hline \multirow{2}{*}{ Grupos } & \multirow{2}{*}{ Amostras } & \multicolumn{4}{c}{ Materiais (em massa) } \\
\cline { 2 - 6 } & & Areia & Cimento & CCCC & a/agl \\
\hline \multirow{2}{*}{ A } & $\mathbf{P}$ & 2,75 & 1,00 & - & 0,568 \\
\cline { 2 - 6 } & $\mathbf{N}$ & 2,50 & 1,00 & 0,25 & 0,584 \\
\hline \multirow{4}{*}{ B } & M2 & 2,75 & 0,975 & 0,025 & 0,622 \\
\cline { 2 - 6 } & M5 & 2,75 & 0,950 & 0,05 & 0,640 \\
\cline { 2 - 6 } & M10 & 2,75 & 0,900 & 0,10 & 0,614 \\
\cline { 2 - 6 } & M15 & 2,75 & 0,850 & 0,15 & 0,586 \\
\cline { 2 - 6 } & M20 & 2,75 & 0,800 & 0,20 & 0,559 \\
\cline { 2 - 6 } & M30 & 2,75 & 0,700 & 0,30 & 0,570 \\
\hline \multirow{4}{*}{ C } & MP2 & 2,75 & 0,975 & 0,025 & 0,622 \\
\cline { 2 - 6 } & MP5 & 2,75 & 0,950 & 0,05 & 0,640 \\
\cline { 2 - 6 } & MP10 & 2,75 & 0,900 & 0,10 & 0,614 \\
\cline { 2 - 6 } & MP15 & 2,75 & 0,850 & 0,15 & 0,586 \\
\cline { 2 - 6 } & MP20 & 2,75 & 0,800 & 0,20 & 0,559 \\
\cline { 2 - 6 } & MP30 & 2,75 & 0,700 & 0,30 & 0,570 \\
\hline
\end{tabular}

Após a moldagem (Figura 4.9), os corpos-de-prova foram mantidos em seus moldes e colocados em câmara úmida à temperatura de $23 \pm 2^{\circ} \mathrm{C}$, por $22 \pm 2 \mathrm{~h}$. Ao final desse período, foram desmoldados e imersos em água saturada com cal, onde permaneceram até a idade de 7 (sete) dias.

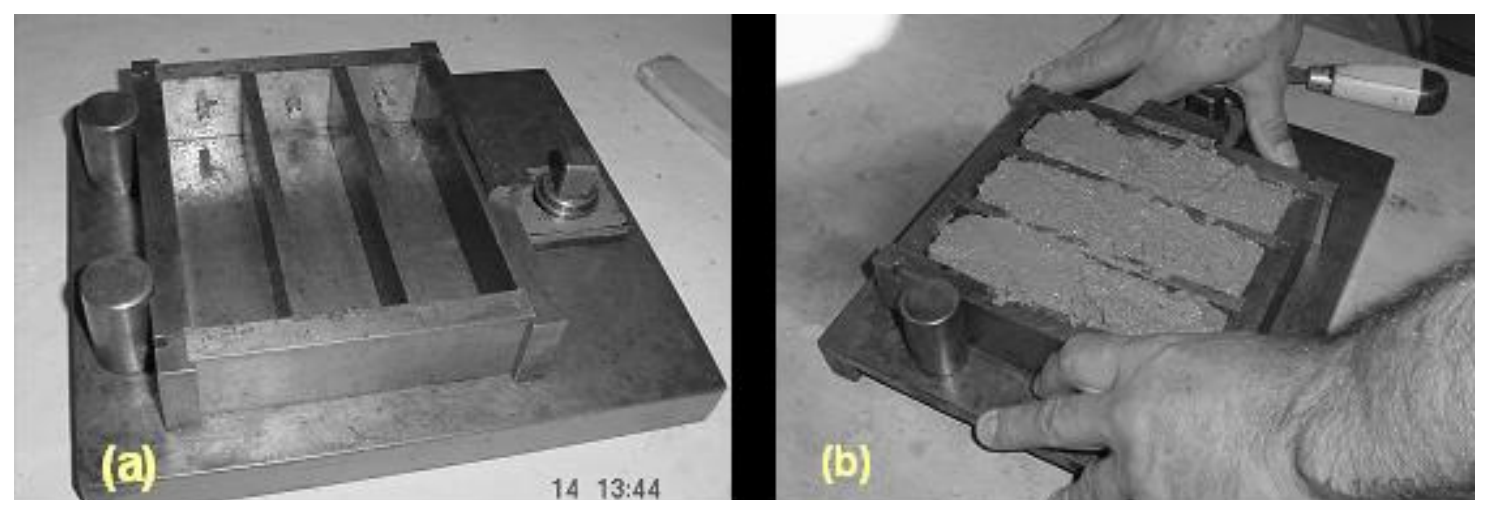

Figura 4.9 - Ensaio de Retração (a) Forma para moldagem. (b) Moldagem e adensamento. 
Ao final do período de cura úmida, aos 7 dias, e imediatamente após a medição inicial, os corpos-de-prova permaneceram armazenados na câmara seca, à temperatura de $23 \pm 2^{\circ} \mathrm{C}$ (Figura 4.10). Decorridos 28 dias de cura em câmara seca, as leituras finais, exigidas pela norma 12650 (ABNT, 1992) foram realizadas dentro da própria câmara a fim de se evitarem influências da umidade e da temperatura sobre os resultados. As leituras foram feitas por aparelho de medição com precisão de 1/100mm, conforme Figura 4.10.

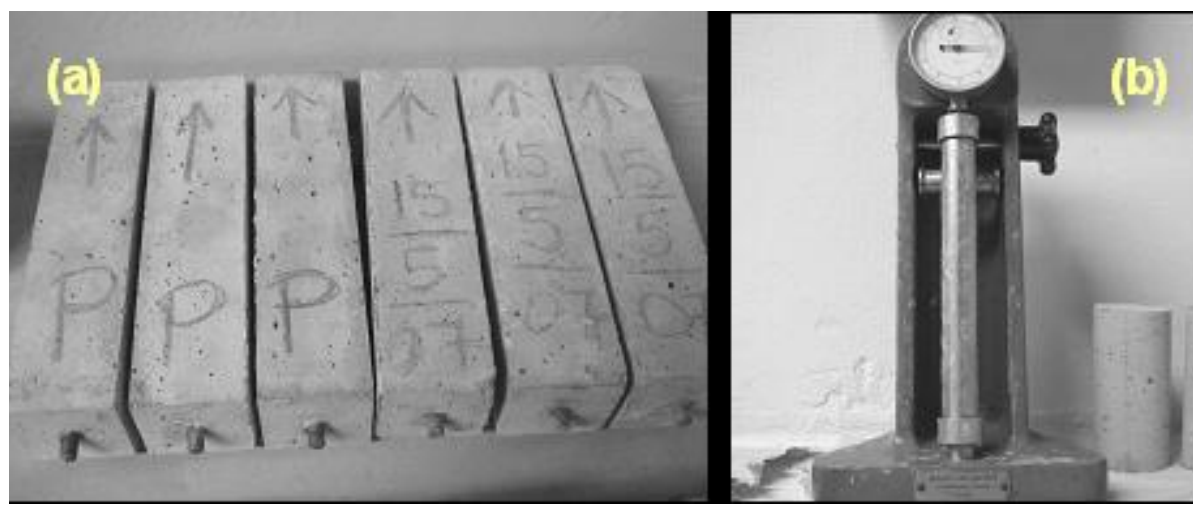

Figura 4.10 - (a) Corpos-de-prova identificados e armazenados em câmara seca de temperatura controlada. (b) Aparelho de medição da retração - Unidade: 1/100mm.

As demais leituras, nas idades adicionais de 14, 56 e 119 dias também foram realizadas nas mesmas condições das anteriores.

\subsubsection{Análise da profundidade de carbonatação}

Apesar da discussão do comportamento das matrizes cimentícias serem baseadas, na maioria das vezes, na aceitação de que o ar do meio ambiente não reage com a pasta de cimento hidratada, o $\mathrm{CO}_{2}$ apresenta-se como um agente deletério ao transformar-se em ácido carbônico. A ação do $\mathrm{CO}_{2}$ ocorre mesmo em ambientes rurais, onde seus teores ficam em torno de $0,03 \%$. Dos componentes da pasta de cimento, o que reage mais rapidamente com o $\mathrm{CO}_{2}$ é o hidróxido de cálcio $(\mathrm{CH})$, resultando em $\mathrm{CaCO}_{3}(\mathrm{NEVILLE}, 1997)$.

As técnicas de laboratório que podem ser utilizadas para determinar a profundidade de carbonatação incluem desde análise química a análise termogravimétrica. Porém esta pesquisa escolheu um método bastante simples, denominado método colorimétrico, citado por Neville (1997), para se determinar a extensão da carbonatação.

O método consiste em se tratar uma superfície recém rompida com solução de fenolftaleína diluída em álcool. $\mathrm{O} \mathrm{CH}$ adquire uma tonalidade rosada (componente básico, 
$\mathrm{pH}>7,0$ ) enquanto a parte que sofreu carbonatação (componente ácido, $\mathrm{pH}<7,0$ ) permanece inalterada. Neville (1997) adverte que a cor rosa pode indicar a presença de $\mathrm{CH}$, mas não a ausência total de carbonatação. Portanto, esse ensaio deve ser empregado como método comparativo entre amostras, essencialmente qualitativo.

Para a análise da influência do uso da CCCC no teor de carbonatação de matrizes cimentícias, foram moldados 2 (dois) corpos-de-prova para cada amostra, ambos analisados aos 90 e 180 dias.

As amostras do Grupo A foram confeccionadas com teores de CCCC entre 2,5 e 30\%, sendo essa moída durante 1 hora no moinho de bolas. O Grupo B obteve o mesmo tratamento do grupo anterior, com a diferença de que a CCCC foi passada na peneira $n^{\circ} 200$ (abertura 0,075mm) após a moagem, sendo utilizado apenas o material passante.

O teor de água foi determinado pelo índice de consistência (flow table test, Figura 4.4), no valor entre 220 e $230 \mathrm{~mm}$, para o grupo $A$. O fator água/aglomerante do Grupo $A$ foi repetido para o Grupo $B$ para que se pudesse manter fixas todas as variáveis entre esses dois grupos, possibilitando a análise comparativa dos resultados ao término do ensaio. A Tabela 4.14 apresenta os traços e os materiais utilizados nesse ensaio.

Tabela 4.14 - Dados para moldagem dos corpos-de-prova em argamassa para o ensaio de carbonatação

\begin{tabular}{cccccc}
\hline \multirow{2}{*}{ Grupos } & \multirow{2}{*}{ Amostras } & \multicolumn{5}{c}{ Materiais } \\
\cline { 2 - 6 } & & Areia & Cimento & CCCC & a/agl \\
\hline REFERÊNCIA & $\mathbf{P}$ & 2,75 & 1,00 & - & 0,568 \\
\hline \multirow{4}{*}{ A } & M2 & 2,75 & 0,975 & 0,025 & 0,622 \\
\cline { 2 - 6 } & M5 & 2,75 & 0,950 & 0,05 & 0,640 \\
\cline { 2 - 6 } & M10 & 2,75 & 0,900 & 0,10 & 0,614 \\
\cline { 2 - 6 } & M15 & 2,75 & 0,850 & 0,15 & 0,586 \\
\cline { 2 - 6 } & M20 & 2,75 & 0,800 & 0,20 & 0,559 \\
\hline \multirow{4}{*}{ B } & M30 & 2,75 & 0,700 & 0,30 & 0,570 \\
\hline & MP2 & 2,75 & 0,975 & 0,025 & 0,622 \\
\cline { 2 - 6 } & MP5 & 2,75 & 0,950 & 0,05 & 0,640 \\
\cline { 2 - 6 } & MP10 & 2,75 & 0,900 & 0,10 & 0,614 \\
\cline { 2 - 6 } & MP15 & 2,75 & 0,850 & 0,15 & 0,586 \\
\cline { 2 - 6 } & MP20 & 2,75 & 0,800 & 0,20 & 0,559 \\
\cline { 2 - 6 } & MP30 & 2,75 & 0,700 & 0,30 & 0,570 \\
\hline
\end{tabular}


Após a moldagem, os corpos-de-prova foram mantidos em seus moldes em câmara seca com temperatura controlada $\left(23^{\circ} \mathrm{C} \pm 2^{\circ} \mathrm{C}\right)$ por 24 horas. Ao final deste período foram desmoldados e mantidos em câmara úmida à temperatura de $(23 \pm 2)^{\circ} \mathrm{C}$, por 27 dias. Após a fase de cura úmida, os corpos-de-prova permaneceram em ambiente de laboratório até a data de análise, nas idades anteriormente mencionadas.

\subsubsection{Determinação da capacidade de estabilização/solidificação da CCCC pela matriz cimentícia}

O termo "encapsulamento de resíduos" tem sido utilizado no Brasil, e também em outros países, para definir uma tecnologia de tratamento de resíduos que utiliza processos de estabilização de contaminantes (PASSOS e NEDER, 2000).

O encapsulamento de resíduos sólidos é um processo também conhecido como Estabilização/Solidificação ${ }^{26}$ e vem sendo utilizado como alternativa aos processos tradicionais de tratamento, principalmente para facilitar o manuseio, o transporte e 0 armazenamento (PABLOS \& SICHIERI, 2007).

Verificados os altos índices de metais pesados no extrato solubilizado da CCCC, na primeira fase de ensaios, considerou-se relevante a análise dessa cinza em condição solidificada pela matriz.

O objetivo da tecnologia S/S aplicada ao tratamento de resíduos é conter os contaminantes e prevenir que estes não se disseminem pelo meio ambiente. Essa imobilização pode ocorrer por meio de processos químicos ou físicos. A imobilização física ocorre quando o contaminante é encapsulado em uma matriz sólida e na imobilização química acontece a transformação do elemento contaminante por meio de reações químicas (MERRIT et al., 1993).

A imobilização por meio de ligantes hidráulicos, como, por exemplo, o cimento Portland, não requer tratamentos térmicos para transformar resíduos nocivos em inertes, imersos em uma matriz estável. O produto final torna-se resistente a agentes ambientais agressivos e tem sido usualmente aprovado nos ensaios de lixiviação, podendo, por conseguinte, ser depositado em aterros de forma segura. Entretanto, esse processo vem

\footnotetext{
${ }^{26} \mathrm{Na}$ literatura internacional encontra-se Stabilization/Solidificaton, símbolo $\mathbf{S} / \mathbf{S}$, simbologia utilizada por este trabalho.
} 
experimentando uma crescente oposição em muitos países da Comunidade Européia, em virtude da estabilidade dos materiais cimentícios não ser ainda definitivamente comprovada. Outra razão se refere ao volume da mistura cimentante, uma vez que essa é bem maior que o do resíduo, o que reduz a capacidade dos aterros (PELINO, 2000).

Ainda assim, várias pesquisas (MERRIT et al, 1993; HEBATPURIA et al., 1999; REDDI et al., 1996; ZHANG \& BISHOP, 2002; PABLOS \& SICHIERI, 2007; YIN et al., 2008; entre outros) atestam a validade do processo $\mathrm{S} / \mathrm{S}$ por meio de ligantes hidráulicos, como cimento e cal, por conterem estes altas quantidades de óxido de cálcio ( $\mathrm{CaO})$, um elemento essencial para se elevar o $\mathrm{Ph}$ da mistura e facilitar os mecanismos de precipitação dos contaminantes. Segundo Daniali (1990), por exemplo, a fixação de resíduos sólidos perigosos em matriz de cimento Portland é a técnica S/S mais comumente utilizada, devido à simplicidade do processo e ao baixo custo.

Para se determinar a capacidade de estabilização/solidificação da CCCC pela matriz cimentícia, foram moldadas 4 (quatro) pastas com teores de $0 \%$ a $10 \%$ de CCCC em substituição ao cimento Portland, utilizando corpos-de-prova cilíndricos de 50x100mm. O fator água/agl foi mantido constante para todos os traços, no valor de 0,36. A CCCC utilizada nesse ensaio foi moída durante 1 (uma) hora no moinho de bolas.

Após a moldagem, os corpos-de-prova foram levados para a câmara seca (temperatura $23 \pm 2^{\circ} \mathrm{C}$ ) e aos 28 dias foram rompidos, triturados e peneirados (\# abertura 9,5mm). Parte do material passante (250 gramas) foi acondicionado em recipiente apropriado e submetido ao ensaio de solubilização (NBR 10006/04) pelo Laboratório de Saneamento do Departamento de Engenharia Hidráulica e Sanitária da Escola de Engenharia de São Carlos (EESC/USP).

No capítulo seguinte são apresentados e discutidos os resultados obtidos na fase de desenvolvimento experimental deste trabalho. 
Capítulo

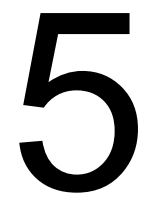

\section{APRESENTAÇÃO E DISCUSSÃO DOS RESULTADOS}

Neste capítulo são apresentados e discutidos os resultados obtidos por meio das análises descritas no Capítulo 4, divididas em 5 (cinco) etapas principais: i) Caracterização físico-química da CCCC; ii) Análise do potencial pozolânico da CCCC; iii) Análise de retração por secagem; iv) Análise da profundidade de carbonatação; e v) Estudo da capacidade de estabilização/solidificação da CCCC pela matriz cimentícia.

\subsection{Caracterização físico-química da CCCC}

A análise química da $\operatorname{CCCC}$ foi realizada no Centro de Caracterização e Desenvolvimento de Materiais - CCDM e a análise da superfície específica pelo método BET foi realizada no Departamento de Engenharia Química, ambos da Universidade Federal de São Carlos. As determinações da massa específica e da massa unitária foram realizadas no Laboratório de Construção Civil do Departamento de Arquitetura e Urbanismo (SAP/EESC/USP). As imagens de MEV foram feitas no Laboratório de Microscopia Eletrônica e a análise de $\operatorname{DrX}$ da CCCC in natura foi realizada no Laboratório Cristalografia de Raios X, ambos do Instituto de Física de São Carlos (IFSC/USP).

\subsubsection{Análise química}

Nos resultados da análise química da CCCC (Tabela 5.1), nota-se um teor de sílica $\left(\mathrm{SiO}_{2}\right)$ no valor de $12,17 \%$, abaixo dos teores recomendados por outras pesquisas (CINCOTTO, 1988; PRUDÊNCIO Jr \& SANTOS, 1997; JOHN et al., 2003) para que uma cinza apresente reatividade.

Para John et al. (2003), na avaliação da reatividade de uma adição mineral, mostra-se de fundamental importância realizar uma análise química completa, devendo esse material sempre apresentar silício como elemento predominante. 
Tabela 5.1 - Análise química da CCCC

\begin{tabular}{cccccccccccc}
\hline Constituntes & $\mathrm{SiO}_{2}$ & $\mathrm{Al}_{2} \mathrm{O}_{3}$ & $\mathrm{Fe}_{2} \mathrm{O}_{3}$ & $\mathrm{Na}_{2} \mathrm{O}$ & $\mathrm{CaO}$ & $\mathrm{K}_{2} \mathrm{O}$ & $\mathrm{MgO}$ & $\mathrm{TiO}_{2}$ & $\mathrm{P}_{2} \mathrm{O}_{5}$ & $\mathrm{MnO}$ & $\mathrm{PF}$ \\
\hline Amostra (\%) & 12,17 & 1,37 & 3,06 & 2,15 & 6,54 & 24,79 & 16,34 & 0,087 & 10,08 & 0,29 & 17,90 \\
\hline
\end{tabular}

A NBR 12653 (ABNT, 1992) determina que os constituintes presentes nos materiais pozolânicos atendam aos parâmetros mínimos, especificados na Tabela 5.2. Por essa norma, a CCCC não apresenta as exigências mínimas que a classifiquem como "material pozolânico classe E”.

No entanto, apesar de ser um ponto de partida para classificar as adições minerais como materiais pozolânicos, Malhotra \& Mehta (1996) divergem à respeito de normas como a NBR 12653, por vários motivos, entre eles: i) A quantidade mínima de $50 \%$ de $\left(\mathrm{SiO}_{2}+\right.$ $\mathrm{Al}_{2} \mathrm{O}_{3}+\mathrm{Fe}_{2} \mathrm{O}_{3}$ ) não apresenta relação direta com as propriedades do material; e ii) Parte-se do princípio de que o material encontra-se na fase amorfa, o que muitas vezes não ocorre.

Tabela 5.2 - Exigências físicas estabelecidas para materiais pozolânicos

\begin{tabular}{ccc}
\hline PROPRIEDADES & CCCC (\%) & NBR 12653 - CLASSE "E" \\
\hline $\mathrm{SiO}_{2}+\mathrm{Al}_{2} \mathrm{O}_{3}+\mathrm{Fe}_{2} \mathrm{O}_{3}$ & $\mathbf{1 6 , 6 0}$ & 50,00 \\
\hline $\mathrm{SO}_{3}, \%$ máx. & - & 5,00 \\
\hline teor de umidade, $\%$ máx. & - & 3,00 \\
\hline perda ao fogo, \% máx. & $\mathbf{1 7 , 9 0}$ & 6,00 \\
\hline álcalis disponíveis em $\mathrm{Na}_{2} \mathrm{O}, \%$ máx. & $\mathbf{2 , 1 5}$ & 1,50 \\
\hline
\end{tabular}

Fonte: NBR 12653/92

Além disso, não estão contemplados os materiais cimentantes ou cimentantes/pozolânicos, desconsiderando o efeito benéfico proporcionado pela existência de maiores teores de óxido de cálcio $(\mathrm{CaO})$. Portanto, apenas a análise química não deve ser um fator determinante na reatividade da CCCC, sendo apenas indicativa em relação às quantidades de materiais potencialmente reativos.

Pela análise química, observou-se também a expressiva quantidade de magnésia (MgO), 16,34\%, de sódio $\left(\mathrm{Na}_{2} \mathrm{O}\right), 2,15 \%$, e de potassa $\left(\mathrm{K}_{2} \mathrm{O}\right), 24,79 \%$, presentes na CCCC.

Esses constituintes, denominados álcalis, podem prejudicar o desempenho dos produtos à base de cimento (NEVILLE, 1994; MEHTA \& MONTEIRO, 1994). Os álcalis são representados pelos elementos $\mathrm{Na}_{2} \mathrm{O}, \mathrm{K} 2 \mathrm{O}, \mathrm{MgO}, \mathrm{CaO}$ e podem provocar a decomposição do concreto e influenciar a velocidade do aumento da resistência mecânica desse material. 
Os mesmos autores argumentam que ainda não foram bem estabelecidos os efeitos desses compostos sobre a matriz de cimento. No entanto, pode-se dizer que quanto maior o teor de álcalis, menor a evolução da resistência mecânica. Em geral, aumentam as resistências iniciais e diminuem as finais.

Para John et al. (2003), a presença de um teor elevado de sódio $\left(\mathrm{Na}_{2} \mathrm{O}\right)$ e potassa $\left(\mathrm{K}_{2} \mathrm{O}\right)$ é indesejável na maioria das aplicações, uma vez que sendo solúveis podem causar problemas de eflorescência ou reação álcali-agregado. No entanto, em muitas aplicações a ocorrência desse tipo de problema é pouco provável no caso de peças que não serão expostas à água.

Basicamente, o sódio se incorpora na alita e a potassa na belita, como sólido em solução. Esses álcalis aumentam a reatividade de hidratação de ambas, alita e belita, prejudicando as propriedades reológicas na pasta de cimento no estado fresco. Quanto à durabilidade na pasta endurecida, altos teores de álcalis tornam a matriz porosa. Consequentemente, a permeabilidade ao ar e penetrabilidade de água aumenta, resultando em redução da durabilidade e alta suscetibilidade ao ataque de substâncias agressivas e à carbonatação (CHANDRA, 1996).

Mehta \& Monteiro (1994) denominam a reação álcali-agregado de "reação álcali-sílica", uma vez que, dependendo do conteúdo de álcalis de um cimento, o $\mathrm{pH}$ do fluido dos poros pode se apresentar entre 12.5 e 13.5, gerando um fluido cáustico (ou fortemente alcalino) que ataca algumas rochas ácidas (agregados compostos de sílica).

Sendo assim, o teor de $\mathrm{Na}_{2} \mathrm{O}$, por exemplo, não pode ultrapassar $0,6 \%$ em massa no concreto. A NBR 12653 (ABNT, 1992) também limita a quantidade de equivalentes de $\mathrm{Na}_{2} \mathrm{O}$ nos materiais pozolânicos em 1,5\%. O cálculo da equivalência de $\mathrm{Na}_{2} \mathrm{O}$ leva em consideração também o teor de potássio através da equação " $\mathrm{Na}_{2} \mathrm{O}+0,64 \mathrm{~K}_{2} \mathrm{O}$ " (MEHTA \& MONTEIRO, 1994). Por essa fórmula a quantidade de álcalis disponíveis na CCCC fica em $18,02 \%$, limitando seu uso apenas em baixos teores de substituição pelo cimento Portland.

A magnésia $(\mathrm{MgO})$ é outra espécie química que aparece em altos teores na CCCC. Analisando os efeitos da hidratação do MgO cristalino, Mehta \& Monteiro (1994) afirmam que, quando esses compostos estão presentes em quantidades substanciais no cimento, podem causar expansão e fissuração em peças de concreto. O efeito expansivo e deletério do $\mathrm{MgO}$ no cimento foi reconhecido inicialmente em 1884, e atualmente as normas de 
cimento Portland nacionais determinam que a quantidade de $\mathrm{MgO}$ no cimento Portland não deva exceder a 6,5\% em relação a massa de cimento Portland .

Basílio (1984) exemplifica quais as formas em que o MgO se apresenta nos compostos e as implicações desses teores no cimento Portland anidro:

- MgO livre: sob a forma cristalina de periclásio, que quando se apresenta na forma de pequenos grãos, não é nociva;

- MgO em solução sólida no clínquer;

- $\mathrm{MgO}$ como material amorfo.

O mesmo autor afirma que da magnésia total, apenas a fração livre pode dar origem ao periclásio (MgO cristalizado). Quando parte desse componente reage com a água origina a brucita $\left(\mathrm{Mg} \cdot \mathrm{H}_{2} \mathrm{O}\right)$, que ao final da reação, tem seu volume aumentado entre $123 \% \mathrm{e}$ $128 \%$, o que acarreta uma grande força de expansão, de 32 a $38 \mathrm{~kg} / \mathrm{cm}^{2}$. Essa reação geralmente ocorre de forma muito lenta, a não ser que a cimento esteja em condições de exposição constante à água, como por exemplo, no caso da cura úmida. Mesmo assim, a hidratação do periclásio tende a se transformar em brucita.

Chandra (1996) ainda afirma que a magnésia acelera a transição do $C_{2} S$ de $\alpha$ para $\beta \mathrm{e}$ reduz a atividade de hidratação da belita depois de 7 dias. Matrizes que contenham teor de magnésio ( $\mathrm{Mg}>2 \%$ como $\mathrm{MgO}$ ) podem ter acelerada as reações de hidratação nas primeiras idades e retardadas em idades avançadas.

O teor de $10,05 \%$ de $\mathrm{P}_{2} \mathrm{O}_{5}$ (pentóxido de fósforo) pode representar também problemas na matriz cimentícia. Chandra (1996) afirma que na pasta de cimento endurecida, o fosfato (P) aparece principalmente ligado ao $\mathrm{C}-\mathrm{S}-\mathrm{H}$, e que o restante pode se precipitar na forma de fosfato de cálcio, aumentando o tamanho dos cristais de $\mathrm{CH}$ como também o espaço ocupado por esses. Como consequência, ocorre um aumento na porcentagem de poros grandes, e que provavelmente tiveram origem em grandes cristais de $\mathrm{CH}$.

Vale salientar, no entanto, que a simples análise química não permitiu concluir sobre a qualidade da cinza. É necessário, por exemplo, que a sílica amorfa e alumina sejam reativas, devendo esses elementos ácidos fixar $\mathrm{o} \mathrm{CH}$ liberado na hidratação do cimento Portland (PETRUCCI, 1995). 
Com isso, pode-se afirmar que a análise química, por si só, não pode nem deve ser a principal determinante do potencial reativo de uma cinza, visando seu aproveitamento como substituto parcial do cimento Portland em matrizes cimentícias. Apesar do baixo teor de sílica presente na CCCC, outros fatores, como superfície específica, a capacidade de empacotamento e o efeito fíler, podem contribuir na melhora das propriedades de materiais cimentícios confeccionadas com cinzas agroindustriais.

\subsubsection{Massa específica e massa unitária}

A massa específica pode ser definida como a massa do material por unidade de volume, incluindo os poros internos das partículas. O resultado da massa específica da CCCC, obtido pela média de dois ensaios consecutivos, foi de $2,23 \mathrm{~g} / \mathrm{cm}^{3}$.

Esse resultado assemelha-se ao da massa específica da cinza da casca da mamona cujo valor é de $2,26 \mathrm{~g} / \mathrm{cm}^{3}$, e também da cinza da casca do amendoim, com o valor de $2,18 \mathrm{~g} / \mathrm{cm}^{3}$ (CINCOTTO, 1988). Tal resultado, porém, não determina semelhança em relação ao tamanho dos grãos nem com a área específica desses materiais.

O termo massa unitária considera o volume total de um sólido, incluindo o volume de vazios. Os resultados encontrados no ensaio de massa unitária, obtido pela média simples de 3 (três) ensaios consecutivos foi $0,56 \mathrm{~g} / \mathrm{cm}^{3}$.

A massa unitária da CCCC apresenta um valor maior que o da sílica ativa, calculado em $0,20 \mathrm{~g} / \mathrm{cm}^{3}$. Essa diferença aponta para uma melhor compactação das partículas da CCCC em relação as da sílica ativa. Tal resultado pode ser atribuído à forma dos grãos da CCCC ou à variação do tamanho das partículas, o que confere a essas uma maior compacidade.

\subsubsection{Níveis de contaminação}

Segundo a NBR 10004 (ABNT, 2004) "a classificação de resíduos sólidos envolve a identificação do processo ou atividade que Ihes deu origem, de seus constituintes e características, e a comparação destes constituintes com listagens de resíduos e substâncias cujo impacto à saúde e ao meio ambiente é conhecido". Para efeitos da citada norma, os resíduos são classificados em: 
a) resíduos classe I - Perigosos;

b) resíduos classe II - Não perigosos;

- resíduos classe II A - Não inertes.

- resíduos classe II B - Inertes.

Pelas análises do extrato lixiviado, segundo a NBR 10005 (ABNT, 2004), e do extrato solubilizado, pela NBR 10006 (ABNT, 2004), foram encontrados vários metais pesados e Fenol na amostra de CCCC. A listagem completa encontra-se melhor detalhada no Apêndice B.

No entanto não se detectou nenhuma substância listada pelo Anexo D - Substâncias Agudamente Tóxicas (NBR 10004/04). Apenas a substância Fenol aparece na listagem do Anexo E - Substâncias Tóxicas, o que não pode deixar de ser avaliado, na comprovação ou não, da toxicidade da CCCC.

Os resultados da análise dos produtos solubilizados apresentaram valores acima do limite permitido, para várias substâncias químicas, de acordo com o Anexo G - Padrões para o ensaio de solubilização, conforme os valores apresentados na Tabela 5.3.

\section{Tabela 5.3 - Substâncias encontradas no extrato solubilizado da CCCC e os respectivos limites exigidos pela norma NBR 10006 (Anexo C e Anexo G).}

\begin{tabular}{lccc}
\hline Parâmetro & Unidade & Resultado & $\begin{array}{c}\text { Limite máximo no } \\
\text { extrato (mg/L) }\end{array}$ \\
\hline Cádmio & $\mathrm{mg} \mathrm{Cd} / \mathrm{L}$ & $\mathbf{0 , 5 7}$ & 0,005 \\
\hline Chumbo & $\mathrm{mg} \mathrm{Pb} / \mathrm{L}$ & $\mathbf{1 , 3 9}$ & 0,01 \\
\hline Cloretos & $\mathrm{mg} \mathrm{Cl} / \mathrm{L}$ & $\mathbf{9 5 0 , 0 0}$ & 250,00 \\
\hline Cromo Total & $\mathrm{mg} \mathrm{Cr} / \mathrm{L}$ & $\mathbf{3 , 0 9}$ & 0,05 \\
\hline Fenóis Totais & $\mathrm{mg} \mathrm{C} \mathrm{H}_{5} \mathrm{OH}$ & $\mathbf{0 , 0 4 2}$ & 0,01 \\
\hline Ferro Total & $\mathrm{mg} \mathrm{Fe} / \mathrm{L}$ & $\mathbf{1 , 6 8}$ & 0,30 \\
\hline Nitratos & $\mathrm{mg} \mathrm{N} / \mathrm{L}$ & $\mathbf{7 5 , 0}$ & 10,0 \\
\hline Prata & $\mathrm{mg} \mathrm{Ag} / \mathrm{L}$ & $\mathbf{0 , 6 2}$ & 0,05 \\
\hline Sódio & $\mathrm{mg} \mathrm{Na} / \mathrm{L}$ & $\mathbf{1 2 1 7 5}$ & 200,0 \\
\hline Manganês & $\mathrm{mg} \mathrm{Mn} / \mathrm{L}$ & $\mathbf{0 , 2 1}$ & 0,10 \\
\hline
\end{tabular}

Apesar dos valores, no ensaio de solubilização, encontrarem-se bem acima do permitido pela NBR 10006 (ABNT, 2004), os resultados do extrato lixiviado se mantiveram dentro do limite para o grupo dos componentes Inorgânicos, segundo o Anexo F - Limite máximo no extrato obtido no ensaio de lixiviação. Sabe-se que os resultados do ensaio de 
lixiviação são determinantes em relação a classificação de um resíduo em Perigoso (Classe I) ou Não perigoso (Classe II).

Dessa forma, de acordo com a NBR 10004, apesar dos altos níveis de metais pesados e Fenol encontrados no extrato solubilizado, a CCCC pode ser classificada, pelos parâmetros ora apresentados, como Resíduo Não perigoso - Classe II A - Não inerte. Os resíduos com tal classificação podem ter propriedades de biodegradabilidade, combustibilidade ou solubilidade em água.

Ainda em relação aos metais pesados encontrados no extrato solubilizado da amostra de $\mathrm{CCCC}$, em teores de 4 a 100 vezes acima do limite máximo permitido, esta pesquisa considera importante uma análise complementar quanto: i) À origem da provável contaminação da $\mathrm{CCCC}$, sendo uma cinza vegetal, por metais pesados; ii) À origem de um álcool, como o Fenol, encontrado em teores 4 (quatro) vezes maiores que o limite máximo permitido.

Uma das causas da contaminação por metais pesados pode ser devida a utilização de agrotóxicos no cajueiro. Penetrando na casca da castanha, esses produtos podem não ter sido totalmente eliminados durante o processo industrial do qual se origina a CCCC.

Os estudos relativos a metais pesados nos ecossistemas têm indicado concentrações elevadas desses elementos em muitas áreas próximas de complexos industriais urbanos, e também, nas áreas de agricultura altamente tecnificada. Nessas regiões os solos têm sido poluídos com chumbo, cádmio, níquel, prata e outros metais pesados (ALLOWAY, 1995). O aumento anormal das concentrações desses elementos nos solos de tais áreas resulta da deposição atmosférica e da aplicação de fertilizantes, corretivos, agrotóxicos, água de irrigação, resíduos orgânicos e inorgânicos (RAMALHO \& SOBRINHO, 2001).

Segundo a Associação Brasileira de Medicina Complementar ${ }^{27}$, cádmio, chumbo, cromo, e outras substâncias provenientes de agrotóxicos são prejudiciais a saúde humana.

O cádmio (Cd), por exemplo, apresenta-se tóxico para os seres humanos e animais. Intoxicações leves por cádmio podem causar salivação, fadiga, perda de peso, fraqueza muscular e disfunção sexual. O cádmio pode afetar ainda os rins, pulmões, testículos, paredes arteriais, ossos e interfere nos sistemas enzimáticos. O chumbo $(\mathrm{Pb})$ também

\footnotetext{
${ }^{27}$ ABMC - ASSOCIAÇÃO BRASILEIRA DE MEDICINA COMPLEMENTAR. (2007). Agrotóxicos. Disponível em: <http://www. medicinacomplementar.com.br/Biblioteca_de_Intoxicacoes.asp>. Acesso em: 21 Abr. 2007.
} 
mostra-se tóxico para os seres humanos. A intoxicação por chumbo pode causar inicialmente falta de apetite, gosto metálico na boca, desconforto muscular, mal estar, dor de cabeça e cólicas abdominais fortes. O cromo $(\mathrm{Cr})$ é um mineral essencial ao funcionamento do nosso organismo. Porém, quando ingerido am altas doses causa intoxicação. A intoxicação industrial por cromo pode causar dermatites alérgicas, úlceras na pele e carcinomas (tumores cancerígenos). A intoxicação por manganês ( $\mathrm{Mn}$ ) pode ser responsável por anorexia, fraqueza, apatia, insônia e outras perturbações do sono, excitabilidade mental, comportamento alterado, dores musculares, quadro neurológico (tremores simulando o mal de Parkinson) e distúrbios psicológicos.

Quanto às interações com a matriz cimentícia, Chandra (1996) salienta que a presença de metais pesados pode afetar o desenvolvimento das resistências e a hidratação dos produtos cimentícios, como apresentado na Tabela 5.4 .

Tabela 5.4 - Influência dos metais pesados na reatividade hidráulica e na qualidade do cimento e concreto

\begin{tabular}{lccc}
\hline Parâmetro & $\begin{array}{c}\text { Influência na } \\
\text { reatividade } \\
\text { hidráulica }\end{array}$ & $\begin{array}{c}\text { Influência na qualidade do } \\
\text { cimento e concreto } \\
\text { Início e fim de } \\
\text { pega }\end{array}$ & $\begin{array}{c}\text { Desenv. das } \\
\text { resistências }\end{array}$ \\
\hline Cádmio & não afeta & retarda & não afeta \\
\hline Chumbo & $\downarrow \mathrm{C}_{2} \mathrm{~S} \uparrow \mathrm{C}_{3} \mathrm{~A}$ & retarda & diminui \\
\hline Cloretos & $\uparrow \mathrm{C}_{3} \mathrm{~S} \uparrow \mathrm{C}_{3} \mathrm{~A}$ & acelera & aumenta \\
\hline Cromo & $\downarrow \mathrm{C}_{2} \mathrm{~S}$ & acelera & diminui \\
\hline Manganês & $\uparrow \mathrm{C}_{3} \mathrm{~S} \uparrow \mathrm{C}_{2} \mathrm{~S}$ & depende do & diminui \\
& $\uparrow \mathrm{C}_{3} \mathrm{~A} \uparrow \mathrm{C}_{4} \mathrm{AF}$ & teor* & \\
\hline
\end{tabular}

$\left(^{*}\right)$ Quando o manganês ocupa o lugar do $\mathrm{Fe}_{2} \mathrm{O}_{3}(\mathrm{~F})$ no $\mathrm{C}_{4} \mathrm{AF}$ em menos de $50 \%$ de substituição, a pega na matriz cimentícia é acelerada; quando esse teor passa dos $50 \%$, ocorre o fenômeno inverso.

Fonte: Chandra, 1996.

Já a origem do Fenol pode ser atribuída ao LCC - líquido da castanha do caju. Sabese que as cascas das castanhas ainda apresentam LCC mesmo depois de queimadas e separadas da amêndoa (LIMA et al., 2004). O processo de queima, do qual se origina a CCCC, pode não ter eliminado totalmente o Fenol.

O LCC é um composto agressivo a saúde humana, de cor escura e bastante viscoso, extraído da casca da castanha de caju. Segundo Agostini-Costa (2000) os lipídios fenólicos, 
principais componentes do LCC, apresentam propriedades rubefacientes ${ }^{28}$ e vesicantes ${ }^{29}$, produzindo dermatites eczematosas, quando em contato com a pele e as mucosas. Os principais componentes do LCC são constituídos pelos ácidos anacárdicos, derivados do ácido salicílico, seguidos pelos cardóis, derivados do resorcinol, e menores teores de cardanóis.

O LCC contém principalmente cardanol (60-65\%), cardol (15-20\%), material polimérico (10\%), e traços de metilcardol. O extrato dissolvido contém ácido anacárdico (60-65\%), cardol (15-20\%), cardanol (10\%), e traços de metilcardol (CARIOCA et al., 2005).

Cabe salientar que a CCCC é atualmente utilizada como adubo nas plantações de caju, ou destinada a aterros, sem qualquer consideração do perigo do seu manuseio à saúde humana. A presença de umidade em contato com a $\mathrm{CCCC}$, ocasionando solubilidade do material, pode ser altamente danoso ao solo e aos lençóis freáticos, uma vez que algumas das substâncias solúveis presentes na cinza são potencialmente cancerígenas e tóxicas para a saúde humana.

Esse alerta deve ser reportado também às demais cinzas agroindustriais pesquisadas, atualmente, como materiais alternativos para substituição do cimento Portland ou do agregado. Deve-se considerar o risco de contaminação por agrotóxicos ou outras fontes, e submeter esses resíduos à análises de contaminação e estabilização/solidificação, se for o caso.

Em relação à CCCC, uma segunda análise do extrato lixiviado, dessa vez analisando o grupo dos Pesticidas, presente no Anexo F da NBR 10004 (ABNT, 2004), apresenta-se como necessária para uma classificação definitiva e precisa em relação a periculosidade dessa cinza. O referido anexo apresenta uma lista de 12 pesticidas, que encontrados em quantidades acima do limite permitido no extrato lixiviado, podem caracterizar o resíduo como Perigoso (Classe I).

\footnotetext{
28 Rubefaciente. Ver Glossário.

${ }^{29}$ Vesicantes. Idem.
} 


\subsubsection{Superfície específica - BET}

Os dados relativos ao ensaio BET da CCCC são apresentados na Tabela 5.5.

Tabela 5.5 - Dados da superfície específica da amostra analisada (CCCC moída 1h)

\begin{tabular}{ccccc}
\hline Amostra & $\begin{array}{c}\text { Pré- } \\
\text { tratamento }\end{array}$ & Área $\left(\mathrm{cm}^{2} / \mathbf{g}\right)$ & $\mathrm{SE}\left(\mathrm{cm}^{2} / \mathbf{g}\right)$ & $\mathrm{SI}\left(\mathrm{cm}^{2} / \mathbf{g}\right)$ \\
\hline CCCC & moagem & 17.230 & 11.740 & 5.496 \\
\hline
\end{tabular}

SE - Superfície Específica Externa da Partícula

SI - Superfície Específica Interna do Poro

O método BET é largamente utilizado para determinar a superfície específica de materiais sólidos com diferentes tamanhos de poros. Sabe-se que uma limitação do método BET é o fato de que ele somente pode ser aplicado em amostras porosas se estas possuirem poros abertos que possam ser preenchidos pelo gás utilizado (ODLER, 2003).

Pode-se observar que mais de $30 \%$ da superfície específica das partículas de CCCC se referem aos poros internos. Essa característica pode explicar a maior demanda de água de amassamento e a perda de trabalhabilidade da argamassa, quando há a substituição de cimento Portland (CPV ARI) por CCCC acima de $10 \%$.

\subsubsection{Microscopia Eletrônica de Varredura - MEV}

A microscopia de varredura eletrônica é uma das técnicas de caracterização microestrutural mais versáteis, atualmente disponíveis. Uma das aplicações do MEV na engenharia refere-se a análises micromorfológicas, incluindo a morfologia de pós e materiais fragmentados (KHAN, 2007).

Utilizou-se a análise por MEV para obter micro-imagens de partículas de CCCC. Observou-se que estas possuem tamanhos variados, conforme as Figuras 5.1 a 5.3. 


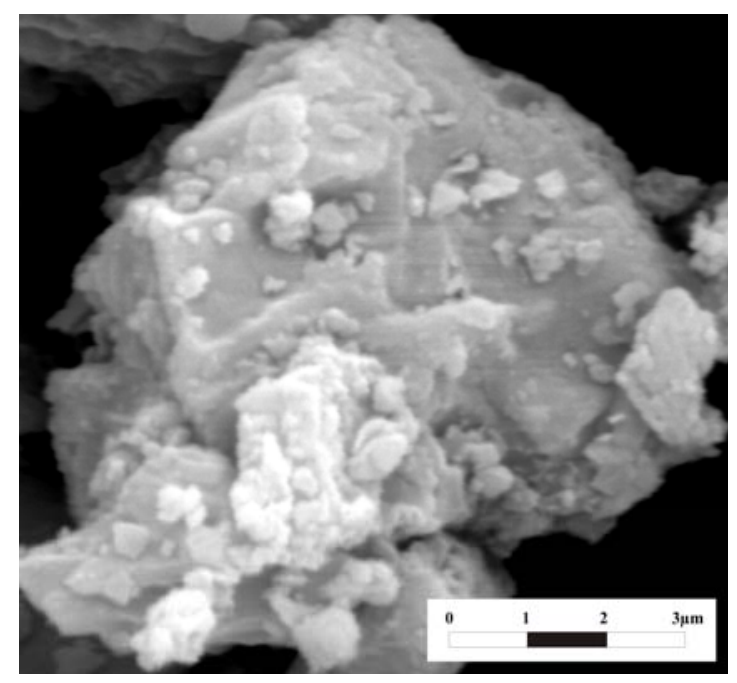

Figura 5.1 - Micrografia com aumento de 10000 vezes

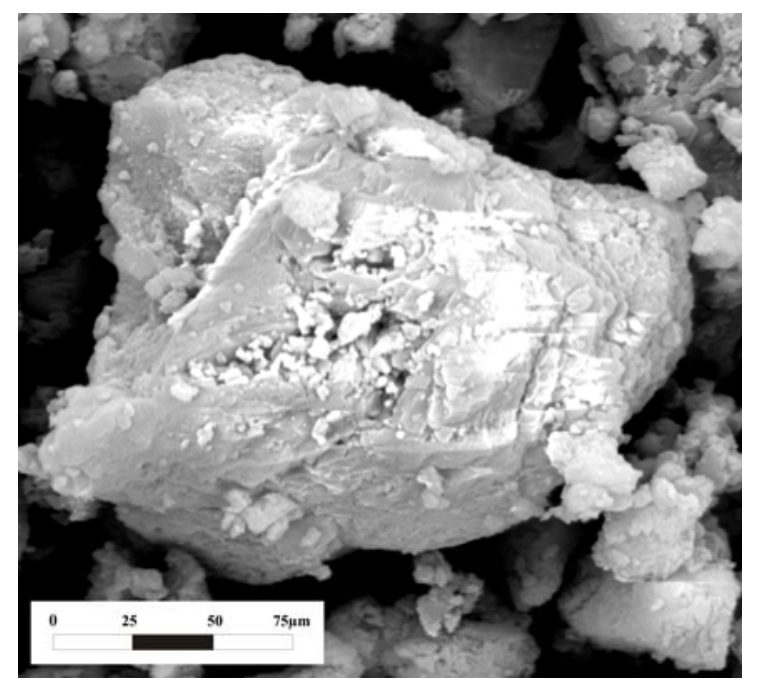

Figura 5.2 - Micrografia com aumento de 3500 vezes

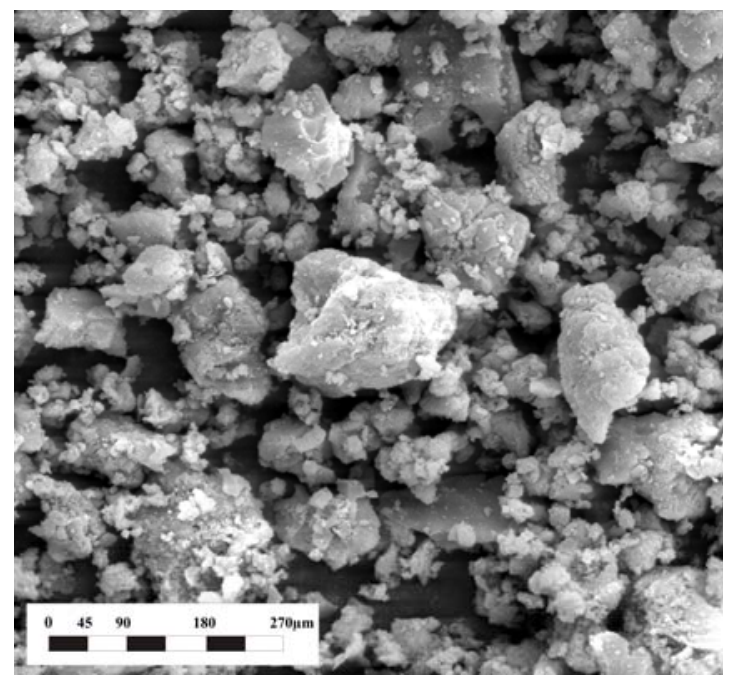

Figura 5.3 - Micrografia com aumento de 1000 vezes 
Nota-se que as partículas da CCCC possuem aspecto lamelar, com camadas sobrepostas e pequenas partículas aderidas à superfície, formando grãos de tamanhos e formatos variados, de aproximadamente 10 a $75 \mu \mathrm{m}$.

Diferentemente de outros materiais pulverulentos utilizados como adições minerais, que possuem formato esférico, a característica lamelar da partícula de CCCC tende a diminuir a trabalhabilidade de argamassas no estado fresco e aumetar o consumo de água. Tal fato foi observado por esta pesquisa ao longo das análises laboratoriais.

\subsubsection{Análise do teor de materiais amorfos por difratometria de raios $X$}

O estudo dos picos presentes no difratograma por comparação em bancos de dados específicos permite a avaliação sobre o quanto uma amostra apresenta-se amorfa ou cristalina, como também sua comparação, de forma qualitativa, com outros materiais de mesma natureza. Utilizou-se essa técnica, portanto, na análise da amostra de CCCC in natura visando a obtenção das fases amorfa e cristalina desse material.

Pelo difratograma da CCCC in natura pode-se observar um halo, característico da presença de material amorfo, entre os ângulos $25^{\circ}$ e $35^{\circ} 2 \theta$, conforme Figura 5.4.

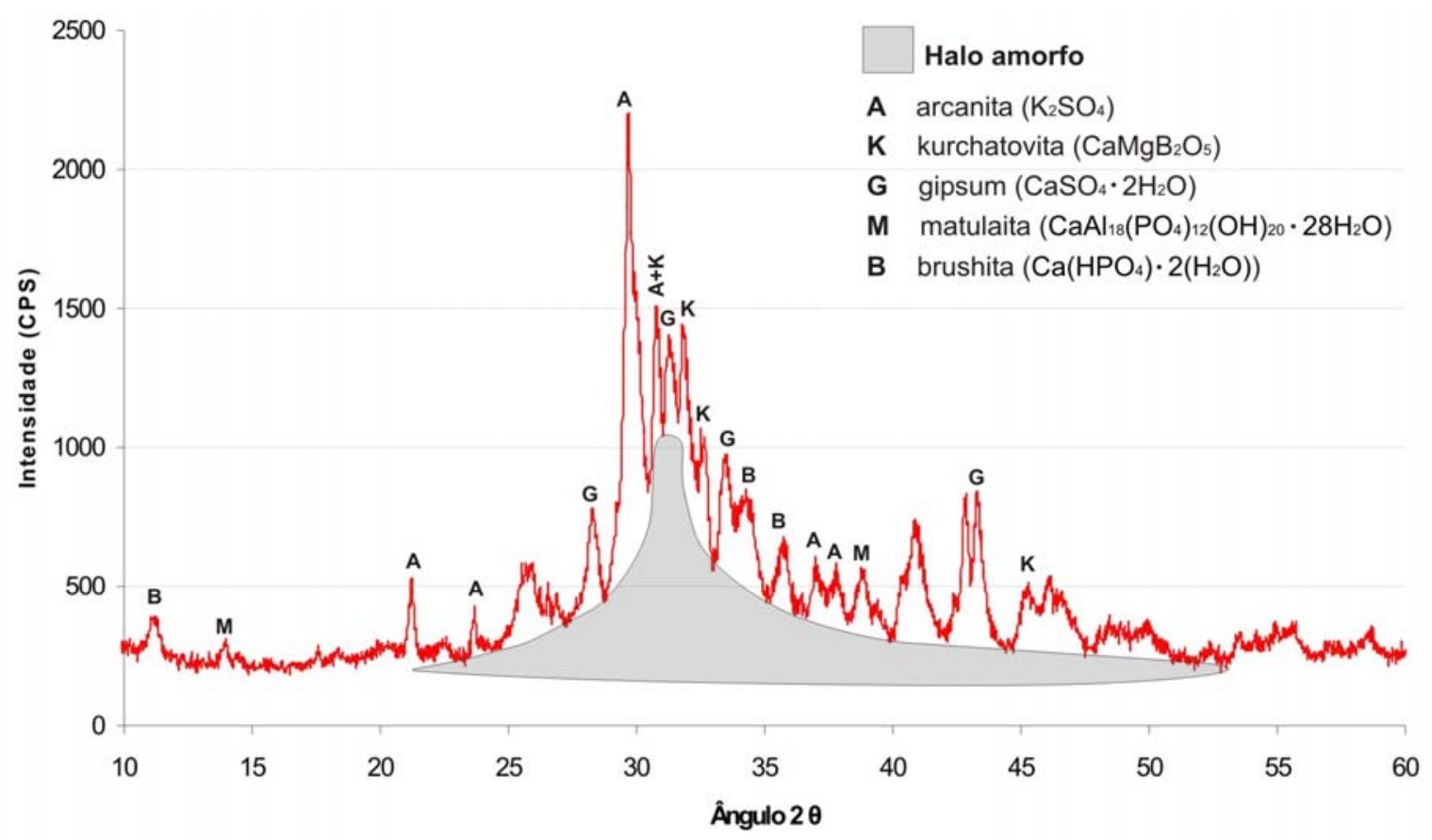

Figura 5.4 - Difratograma de raios X da CCCC in natura 
Pela identificação das fases cristalinas presentes no difratograma da amostra de CCCC (Figura 5.4) pode-se observar os elementos predominantes no pó in natura, com destaque para o mineral Arcanita $\left(\mathrm{K}_{2} \mathrm{SO}_{4}\right.$ - sulfato de potássio), pico identificado no ângulo $30^{\circ}$ 20. Os demais compostos encontrados são formados, predominantemente, pelas espécies químicas Potássio (K), Fósforo $(\mathrm{P})$ e Cálcio $(\mathrm{CA})$, principais constituintes da CCCC, destacados pela análise química.

O sulfato de potássio também foi encontrado em amostras de cinza originadas da queima do bagaço da casca do caju (SANTOS et al., 2007). Esse mineral pode ter origem direta nos fertilizantes utilizados no cajueiro. O sulfato de potássio é comumente utilizado em fertilizantes à base de potássio, podendo ser essa a sua origem, pois esse composto, mesmo tendo custo mais elevado, é recomendado para utilização em diversas culturas como substituto ao cloreto de potássio - KCl (MASCARENHAS et al., 2007).

O enxofre (S) é responsável pela diminuição da taxa de crescimento do cristal de alita e pelo aumento no tamanho do mesmo cristal. Quando a concentração do íon $\left(\mathrm{SO}_{4}{ }^{2-}\right)$ na fase líquida durante a hidratação apresenta-se elevada, formam-se quantidades elevadas de pequenos cristais de etringita que mais tardiamente se transformam em monossulfato. Esse fato pode levar a formação de etringita retardada, ocasionando expansão da pasta de cimento endurecida (CHANDRA, 1996).

\subsubsection{Tempo ótimo de moagem}

Após o término da etapa de moagem e peneiramento das 7 (sete) amostras, observouse que houve redução do teor retido, nas peneiras $n^{\circ} 250$ e 200, segundo demonstram as Figuras 5.5 e 5.6 . 


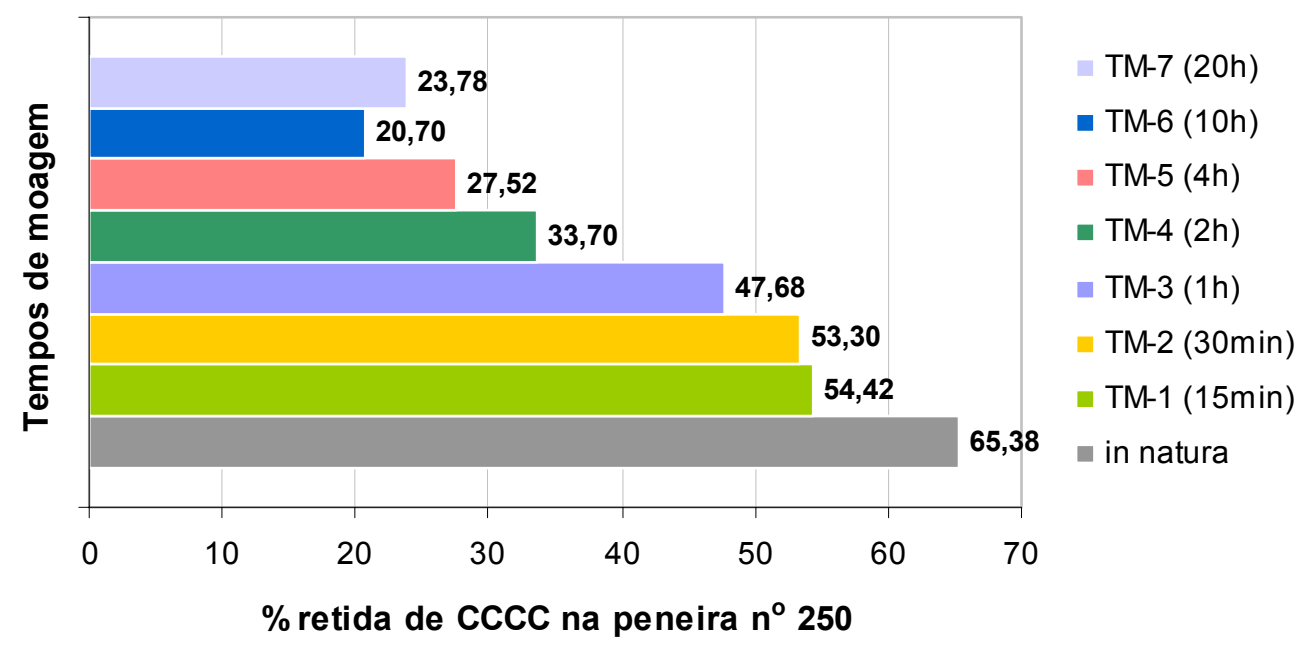

Figura 5.5 - Ensaios de tempo de moagem - peneira $n^{\circ} 250$

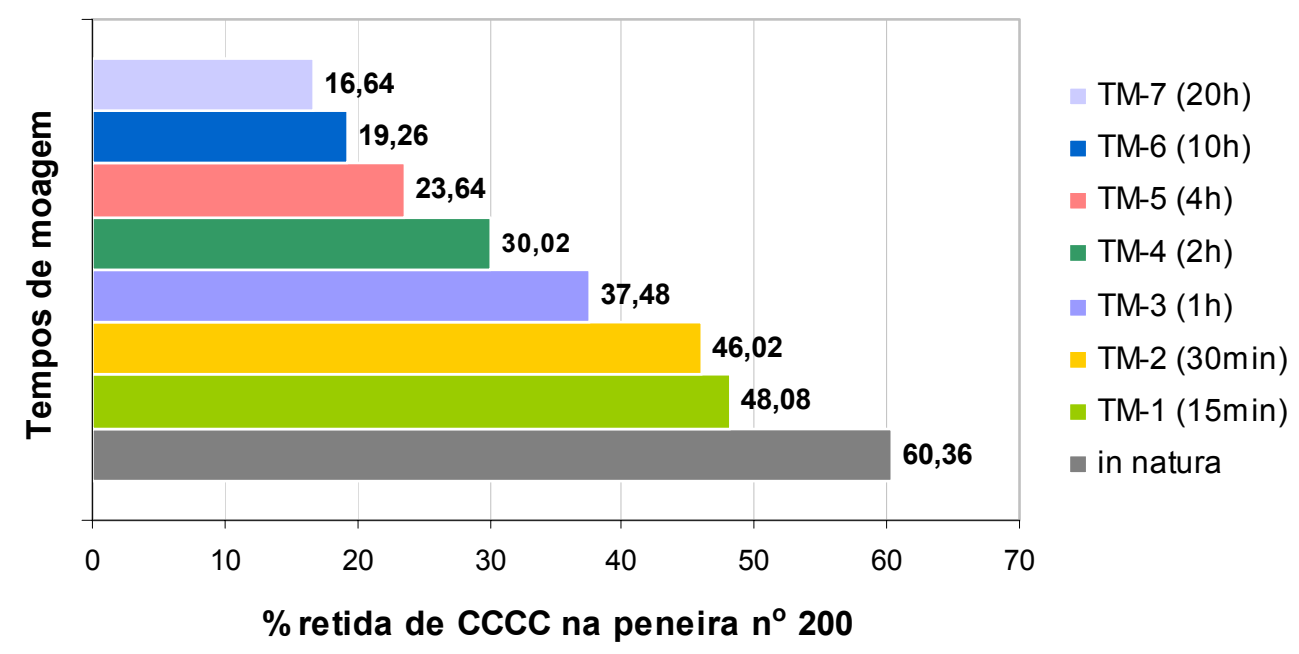

Figura 5.6 - Ensaios de tempo de moagem - peneira $n^{\circ} 200$

Para os tempos de moagem acima de 10 horas, houve um ganho de umidade durante o processo que acarretou na precipitação e percolação do material nas laterais do cilindro e nas esferas metálicas do moinho (Figura 5.7). Tal fato pode ter alterado os resultados da análise de moagem, uma vez que o material aderido às bordas do cilindro pode não ter sido moído adequadamente.

Esse aumento de umidade pode ser atribuído ao alto teor de magnésia ( $\mathrm{MgO})$, uma vez que esse material é altamente higroscópico (BASÍLIO, 1984; MEHTA \& MONTEIRO, 1994; NEVILLE, 1997). Outra hipótese sobre a aderência da CCCC nas bordas do moinho pode ter como origem o LCC presente na cinza, que pode ter sido desprendido durante o processo de moagem. 

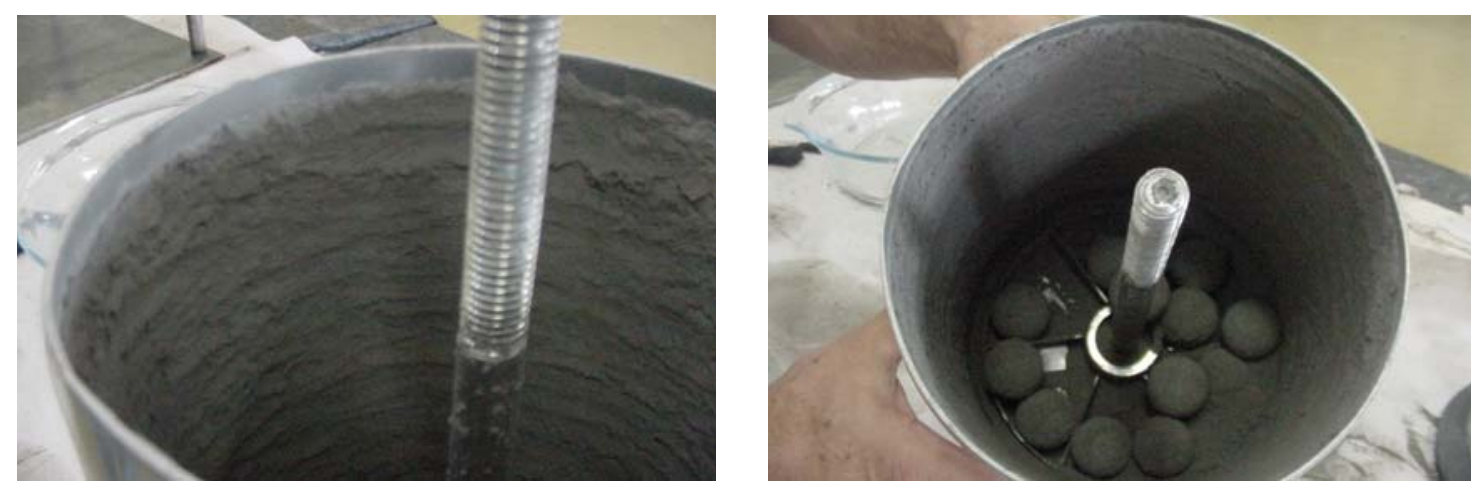

Figura 5.7 - CCCC aderida às laterais e às esferas do moinho para os tempos de moagem acima de 10 horas

Cabe acrescentar que a CCCC possui altos teores de materiais predominantemente cristalinos, potassa $\left(\mathrm{K}_{2} \mathrm{O}\right)$ e magnésia $(\mathrm{MgO})$. A magnésia é considerada um cristal de alta densidade, típico dos materiais cerâmicos, que pode suportar temperaturas extremas - 1650 a $2500^{\circ} \mathrm{C}$ - sem dissociar ou fundir (VAN VLACK, 1970). Tal densidade característica pode ter interferido numa moagem mais efetiva da CCCC.

Durante a etapa de moldagem notou-se a redução na quantidade de água com o aumento do tempo de moagem, observando-se uma diminuição no fator a/agl (água/aglomerante) de 0,62 (amostra 1) para 0,57 (amostra 7). Essa redução, observada na medida em que se aumentou o teor de finura da cinza (maior tempo de moagem) não ultrapassou os $10 \%$, entre o maior e o menor valor, segundo Tabela 5.6.

O traço de referência (amostra 1), sem adição de cinza, requereu maior quantidade de água em relação a outros traços com CCCC (TRAÇOS 5, 6 e 7). No estudo de Prudêncio Jr \& Santos (1997) - Tabela 5.6 - o fator a/agl do traço referência ficou bem abaixo dos demais traços com adição de CCA. Cabe salientar que esses autores utilizaram o cimento CPI S 32, enquanto que nos ensaios com a CCCC foi utilizado o CP $\vee A R I$, notadamente mais fino, o que pode justificar a maior demanda de água para a trabalhabilidade requerida pela norma NBR 5752 (ABNT, 1992).

Em relação ao índice de pozolanicidade (IP), comparando-se com o estudo de Prudêncio Jr \& Santos (1997) para a CCA (cinza da casca do arroz) - Tabela 5.6 - o IP obtido no ensaio com o uso da CCCC foi bastante inferior, não chegando aos $75 \%$ exigido pela norma (Tabela 5.7). 
Tabela 5.6 - Demanda de água e Índice de pozolanicidade - CCA

\begin{tabular}{ccccc}
\hline Amostra & $\begin{array}{c}\text { Tempo de } \\
\text { moagem }\end{array}$ & Fator a/agl & flow test $(\mathbf{m m})$ & IP \\
\hline 0 & - & 0,5199 & 224,00 & - \\
\hline 1 & 15 minutos & 0,6441 & 222,40 & $62 \%$ \\
\hline 2 & 30 minutos & 0,6104 & 225,90 & $83 \%$ \\
\hline 3 & 1 hora & 0,5809 & 220,00 & $106 \%$ \\
\hline 4 & 2 horas & 0,5743 & 223,30 & $113 \%$ \\
\hline 5 & 4 horas & 0,5696 & 226,40 & $126 \%$ \\
\hline 6 & 6 horas & 0,5661 & 220,00 & $123 \%$ \\
\hline 7 & 8 horas & 0,5583 & 220,00 & $119 \%$ \\
\hline 8 & 10 horas & 0,5706 & 222,50 & $118 \%$ \\
\hline 9 & 20 horas & 0,5609 & 226,00 & $115 \%$ \\
\hline
\end{tabular}

Fonte: Prudêncio Jr \& Santos, 1997.

Tabela 5.7 - Demanda de água e Índice de pozolanicidade - CCCC

\begin{tabular}{ccccc}
\hline Amostra & $\begin{array}{c}\text { Tempo de } \\
\text { moagem }\end{array}$ & Fator a/agl & flow test $(\mathbf{m m})$ & IP \\
\hline 0 & - & 0,5996 & 230,00 & - \\
\hline 1 & 15 minutos & 0,6200 & 221,20 & $27 \%$ \\
\hline 2 & 30 minutos & 0,6120 & 220,30 & $35 \%$ \\
\hline 3 & 1 hora & 0,6004 & 220,00 & $30 \%$ \\
\hline 4 & 2 horas & 0,5920 & 221,20 & $32 \%$ \\
\hline 5 & 4 horas & 0,5760 & 222,50 & $36 \%$ \\
\hline 6 & 10 horas & 0,5732 & 225,00 & $34 \%$ \\
\hline 7 & 20 horas & 0,5700 & 220,00 & $33 \%$ \\
\hline
\end{tabular}

Os resultados da análise da resistência à compressão dos corpos-de-prova, aos $28 \mathrm{e}$ 91 dias, demonstraram baixos valores de resistência à compressão dos traços com CCCC em comparação aos da amostra PADRÃO, sem diferença significativa em relação aos tempos de moagem, nem à idade de ruptura, como mostram as Figuras 5.8 e 5.9. 


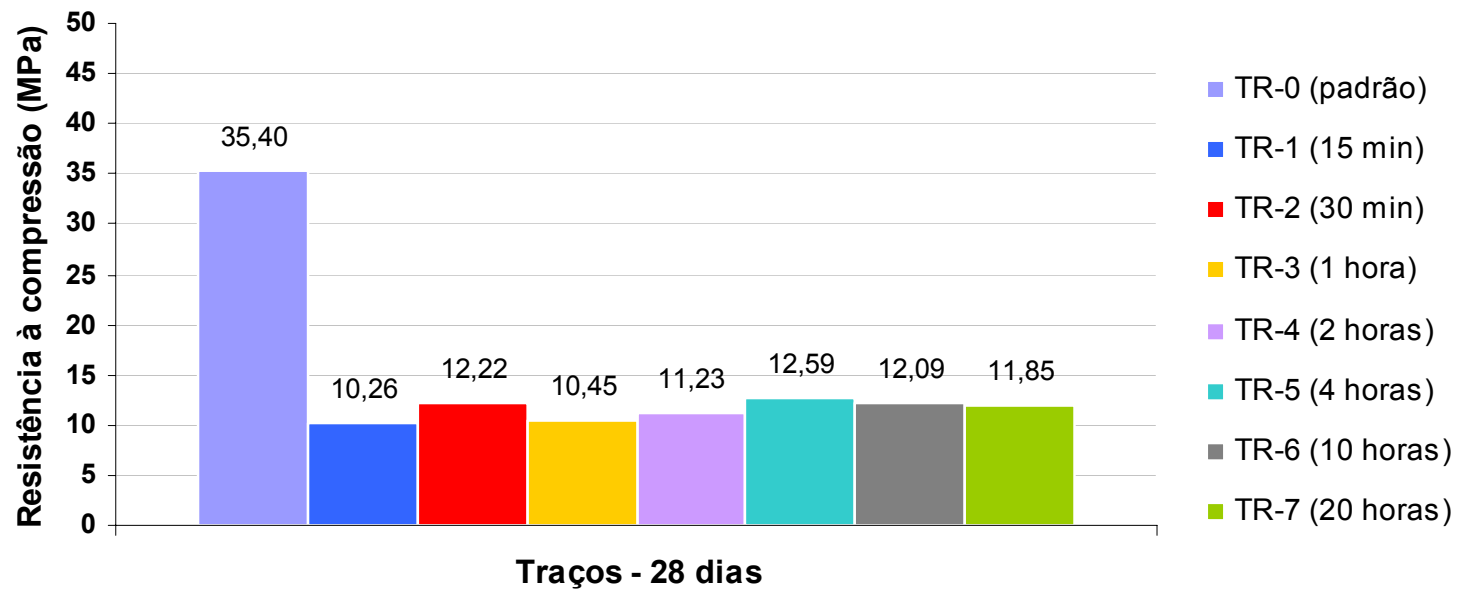

Figura 5.8 - Resistência à compressão aos 28 dias - ensaio de índice de pozolanicidade

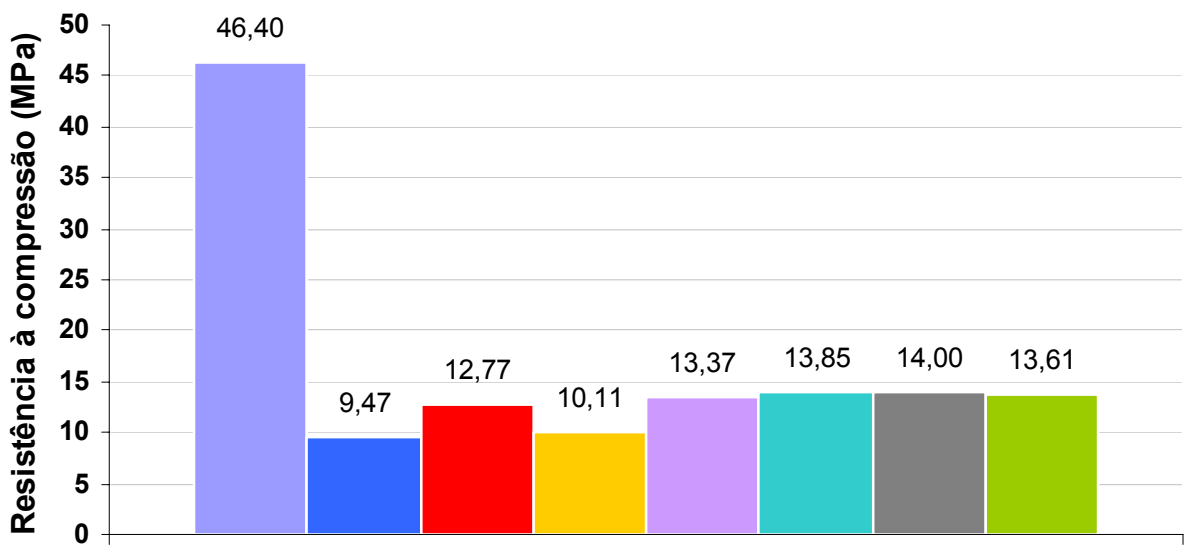

$$
\begin{aligned}
& \text { - TR-0 (padrão) } \\
& \text { - TR-1 (15 min) } \\
& \text { - TR-2 (30 min) } \\
& \text { - TR-3 (1 hora) } \\
& \text { - TR-4 (2 horas) } \\
& \text { - TR-5 (4 horas) } \\
& \text { - TR-6 (10 horas) } \\
& \text { - TR-7 (20 horas) }
\end{aligned}
$$

\section{Traços - 91 dias}

Figura 5.9 - Resistência à compressão aos 91 dias - ensaio de índice de pozolanicidade

Não se pode atestar que as características físicas da CCCC tenham contribuído para alguma melhora nas propriedades da argamassa. A alteração nos tempos de moagem refletiu de maneira significativa na finura do material, mas não a ponto de alterar os valores de resistência à compressão da argamassa.

Malhotra \& Mehta (1996) afirmam que, em geral, os mecanismos pelos quais as adições minerais exercem influência sobre as propriedades dos concretos dependem mais do tamanho, forma e textura das partículas do que à composição química.

No entanto, pelos resultados obtidos nesta pesquisa, tem-se que as características químicas do material podem ter sido preponderantes em relação às físicas. Observa-se um baixo teor de sílica na CCCC, o que limita seu potencial de reatividade com o cimento Portland. 
Apresentam-se na próxima seção os resultados obtidos, bem como a respectiva análise dos mesmos, referentes ao potencial pozolânico da CCCC.

\subsection{Análise do potencial pozolânico da CCCC}

Pelas análises de pozolanicidade da CCCC segundo as NBR 5752 e NBR 5751, assim como a determinação do teor de $\mathrm{CH}$ em pastas pela técnica de difratometria de raios $\mathrm{X}$ e a determinação do teor ótimo de substituição do cimento Portland pela CCCC, pretende-se avaliar a capacidade de reatividade pozolânica da CCCC na matriz cimentícia.

\subsubsection{Atividade pozolânica com a cal e com o cimento Portland}

Para o ensaio de atividade pozolânica com a cal, terminado o tempo de cura, os corpos-de-prova foram capeados com enxofre. No entanto, devido à baixa resistência adquirida durante a cura, não foi possível concluir o capeamento com enxofre devido à desintegração dos corpos-de-prova durante a operação (Figura 5.10).

Essa baixa resistência à compressão, bem inferior aos 6,00MPa exigidos pela norma NBR 5751 (ABNT, 1992), também foi atestada por Camelo et al. (2005). Em seu trabalho, os pesquisadores atingiram menos de 1,00MPa para esse mesmo ensaio, realizado com a cinza da casca da castanha-do-pará.
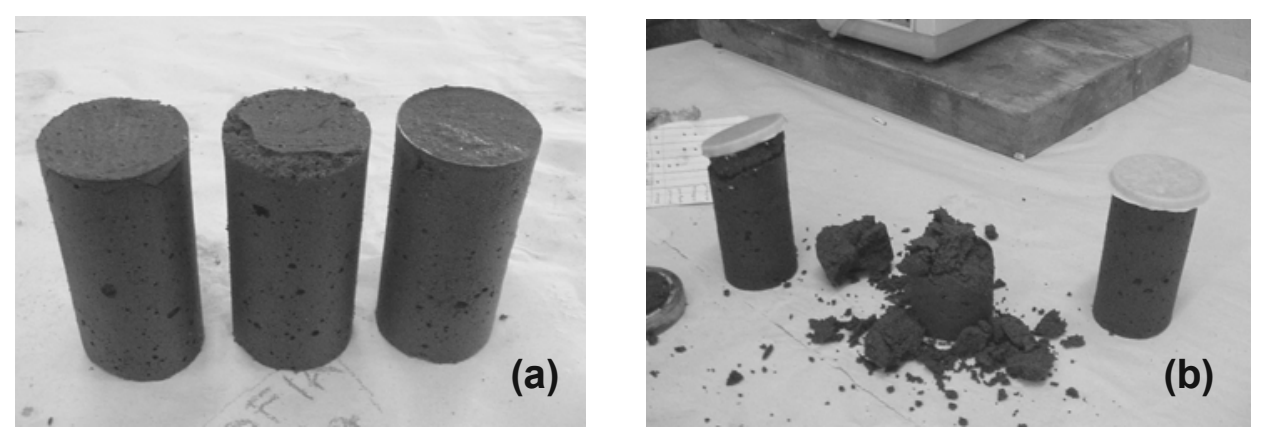

Figura 5.10 - (a) Aspecto dos corpos-de-prova ainda úmidos após 7 dias de cura.

(b) Capeamento com enxofre e desintegração dos corpos-de-prova

John et al. (2003) observaram que em alguns estudos não há correlação entre os resultados da atividade pozolânica obtidos com a mistura de cal e os obtidos com cimento Portland. Na verdade, são dois sistemas diferentes, estudados sob condições de ensaio também diferentes. Não se pode deixar de considerar o efeito da elevada temperatura no 
ensaio com a cal. O ensaio similar, em temperatura ambiente, deve demonstrar resultados bem inferiores. Assim, esse ensaio só seria relevante se a aplicação que se busca para a pozolana envolver a mistura com a cal levada à alta temperatura.

Para o ensaio de atividade pozolânica com o cimento Portland, terminado o tempo de cura, estabelecido pela norma NBR 5752 (ABNT, 1992), os corpos-de-prova foram esfriados à temperatura ambiente, capeados com enxofre e determinado a resistência à compressão simples (Figura 5.11). O índice de pozolanicidade (IP) das amostras A e B em relação à amostra de referência não atingiu os $75 \%$ exigidos pela norma, ficando bem abaixo deste valor, como já tinha sido observado no ensaio que avaliou os tempos de moagem da CCCC.
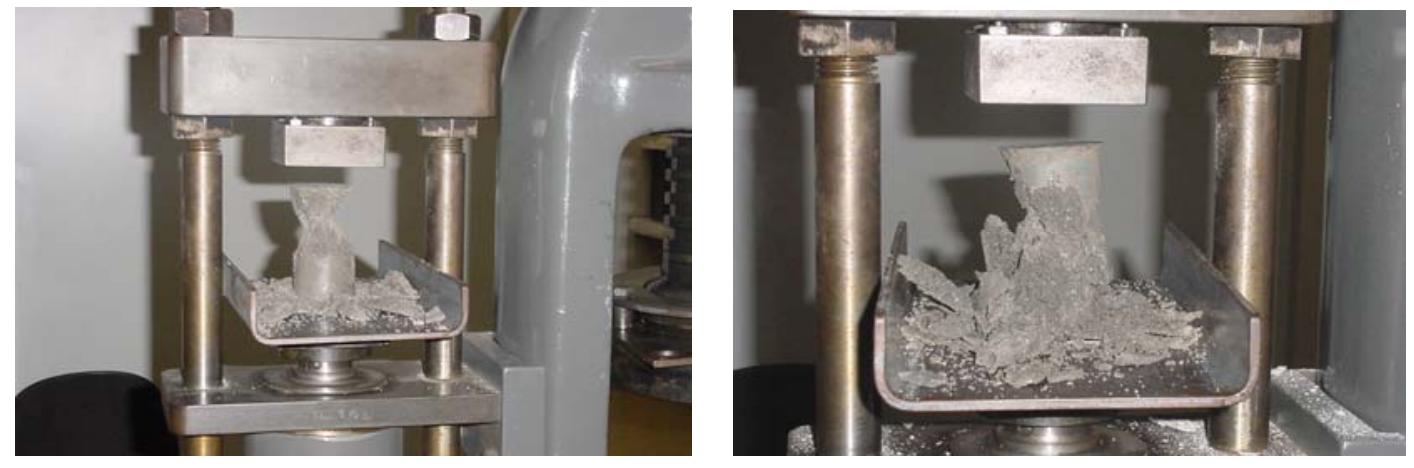

Figura 5.11 - Ruptura dos corpos-de-prova de argamassa - ensaio NBR 5752.

Os valores obtidos pelo ensaio de resistência à compressão, bem como os índices de pozolanicidade de cada amostra encontram-se na Tabela 5.8.

Tabela 5.8 - Resultados - Ensaio NBR 5752/92

\begin{tabular}{cccc}
\hline & Amostra PADRÃO & Amostra A & Amostra B \\
\hline Resistência à compressão (Mpa) & 27,19 & 9,33 & 6,05 \\
\hline Índice de Pozolanicidade & - & 34,31 & 22,25 \\
\hline
\end{tabular}

O teor de CCCC em substituição no valor de $35 \%$ em volume pode ser considerado elevado para aplicação com CCCC. O teor de CCA em substituição, por exemplo, fica em torno de $15 \%$ para a resistência máxima, segundo Prudêncio Jr \& Santos (1997). Ainda assim, a CCCC não se enquadra nos parâmetros mínimos exigidos pela NBR 5752 (ABNT, 1992), não tendo como ser classificada como material pozolânico segundo a mesma. 


\subsubsection{Avaliação da variação do teor de hidróxido de cálcio $(\mathrm{CH})$ em pastas}

Os resultados obtidos pelo ensaio de Difratometria de raios $X(\operatorname{DrX})$ das 15 (quinze) pastas confeccionadas com a CCCC e sílica ativa (SA) encontram-se no Apêndice C. Apresentam-se neste item uma compilação dos valores das intensidades dos picos referentes apenas para as substâncias Portlandita, Etringita e Calcita.

O resumo dos valores da intensidade do pico $2 \theta=18,1^{\circ}$, característico da Portlandita, encontra-se especificado na Figura 5.12. Em relação as análises das pastas, notou-se que os valores referentes às intensidades desse pico diminuiu proporcionalmente ao aumento da substituição de cimento Portland por sílica ativa (SA).

Nas pastas moldadas com substituição de cimento Portland por cinza da casca da castanha de caju (CCCC) houve pequena diminuição no pico referente ao elemento Portlandita (Figura 5.12). Apenas o pico referente ao teor de $30 \%$ teve uma diminuição mais considerável, aproximadamente $50 \%$ em relação a amostra de referência. Como a diminuição do pico da Portlandita não foi linear, uma vez que houve um aumento nos traços com $10 \%$ e $15 \%$ de CCCC, não se pode afirmar qual o fator influenciou mais diretamente: pode ter sido a presença de outros componentes na cinza, que podem estar induzindo a formação de mais $\mathrm{CH}$ na pasta endurecida; o baixo teor de sílica $\left(\mathrm{SiO}_{2}\right)$ da $\mathrm{CCCC}$, insuficiente para reagir com o $\mathrm{CH}$ residual da hidratação do cimento; ou o menor teor de cimento na medida em que se aumentou o teor de CCCC.

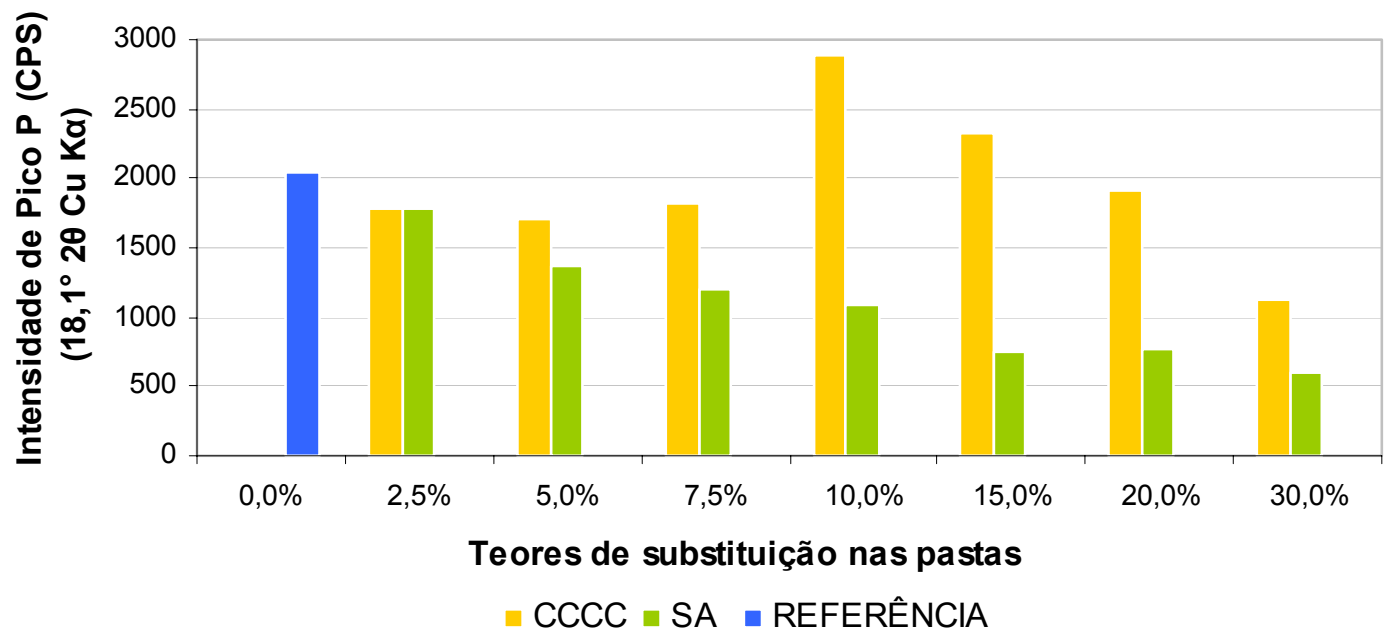

Figura 5.12 - Valores do pico de $\mathrm{P}$ (Portlandita, $\mathrm{CH}$ ), em 18,1 ${ }^{\circ} 2 \theta$ para as pastas analisadas 
Observou-se também que os picos referentes à substância Etringita (E) apresentou diminuição de intensidade nos difratogramas das pastas contendo SA (Figuras 5.13).

Em relação às pastas moldadas com CCCC, houve aumento nos picos referentes a Etringita e a Calcita, como mostram as Figuras 5.13 e 5.14. Porém, tal fato pode ser devido a sobreposição de outros picos referentes aos elementos presentes na cinza, e não apenas por causa da baixa pozolanicidade da CCCC.

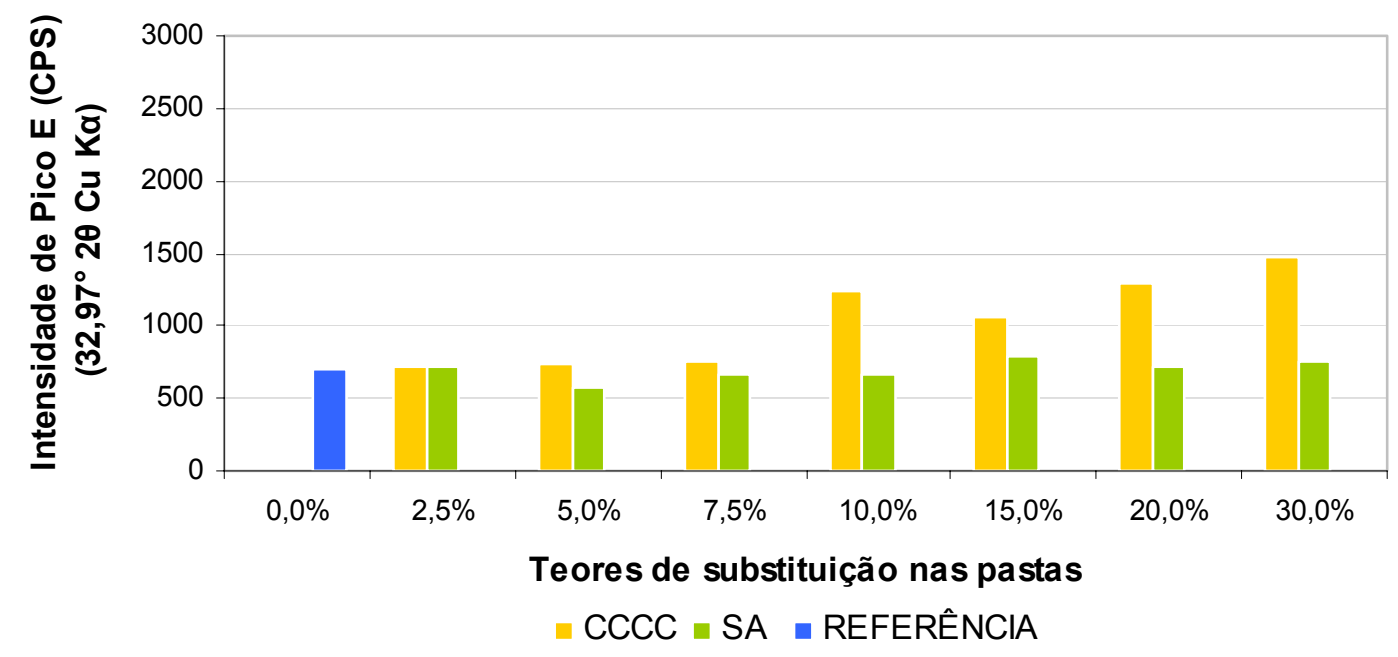

Figura 5.13 - Valores do pico de E (Etringita) em $32,97^{\circ} 2 \theta$ para as pastas analisadas

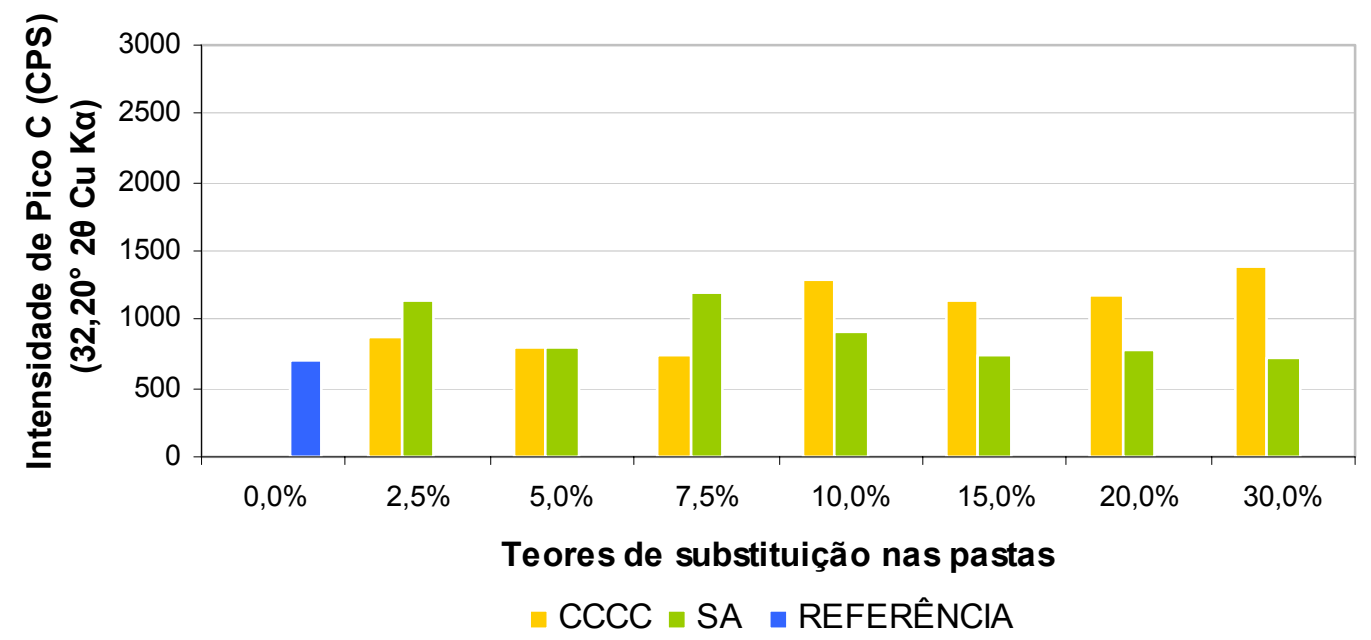

Figura 5.14 - Valores do pico de $\mathrm{C}$ (Calcita), em $32,20^{\circ} 2 \theta$ para as pastas analisadas

Observou-se também, na medida em que se aumentou o teor de CCCC nas pastas, o aparecimento, e progressivo aumento, de picos referentes aos minerais Gorgeita - G $\left(\mathrm{K}_{2} \mathrm{Ca}_{5}\left(\mathrm{SO}_{4}\right) \cdot 6 \mathrm{H}_{2} \mathrm{O}\right)$ e Bruchita - $\mathrm{B}\left(\mathrm{CaPO}_{3}(\mathrm{OH}) \cdot 2 \mathrm{H}_{2} \mathrm{O}\right)$ observados mais claramente nos difratogramas das pastas 14 e 15, como mostram as Figuras 5.15 e 5.16. 


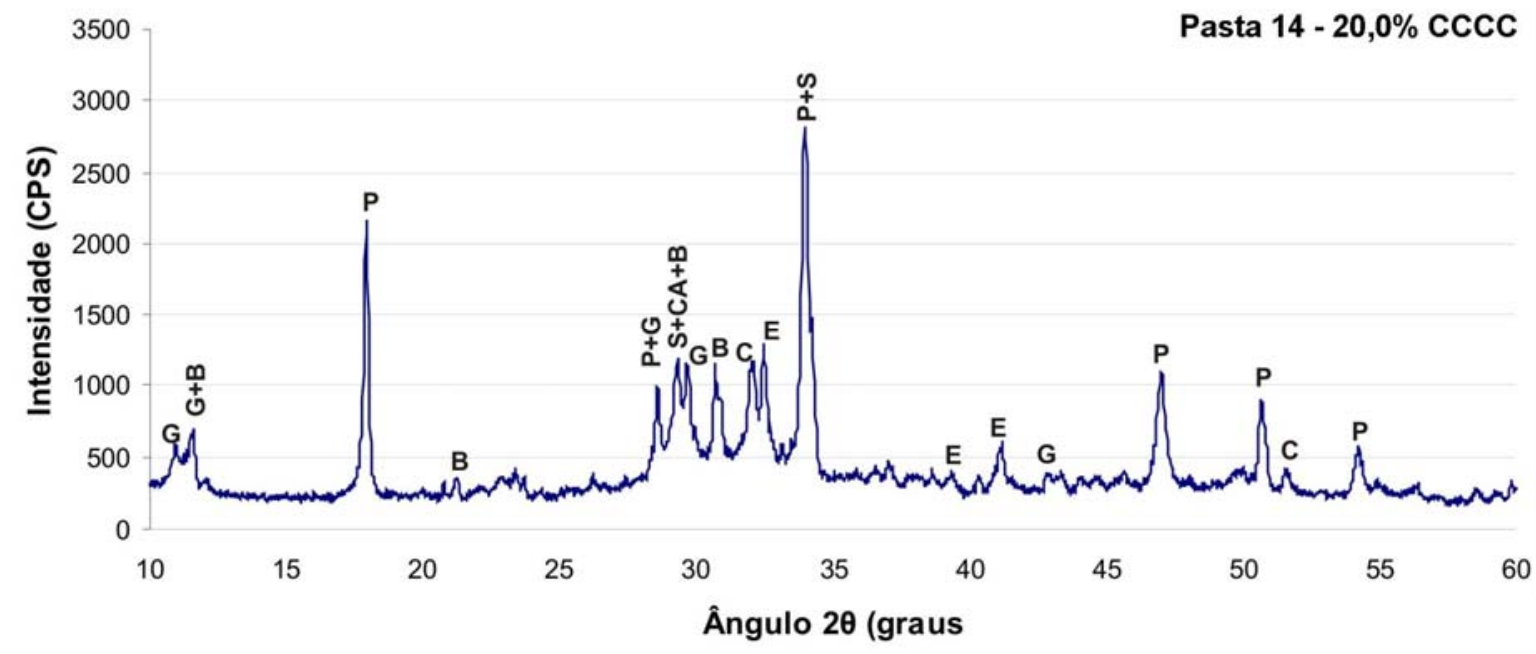

Figura 5.15 - Difratograma de raios X da Pasta $14-20 \%$ de CCCC

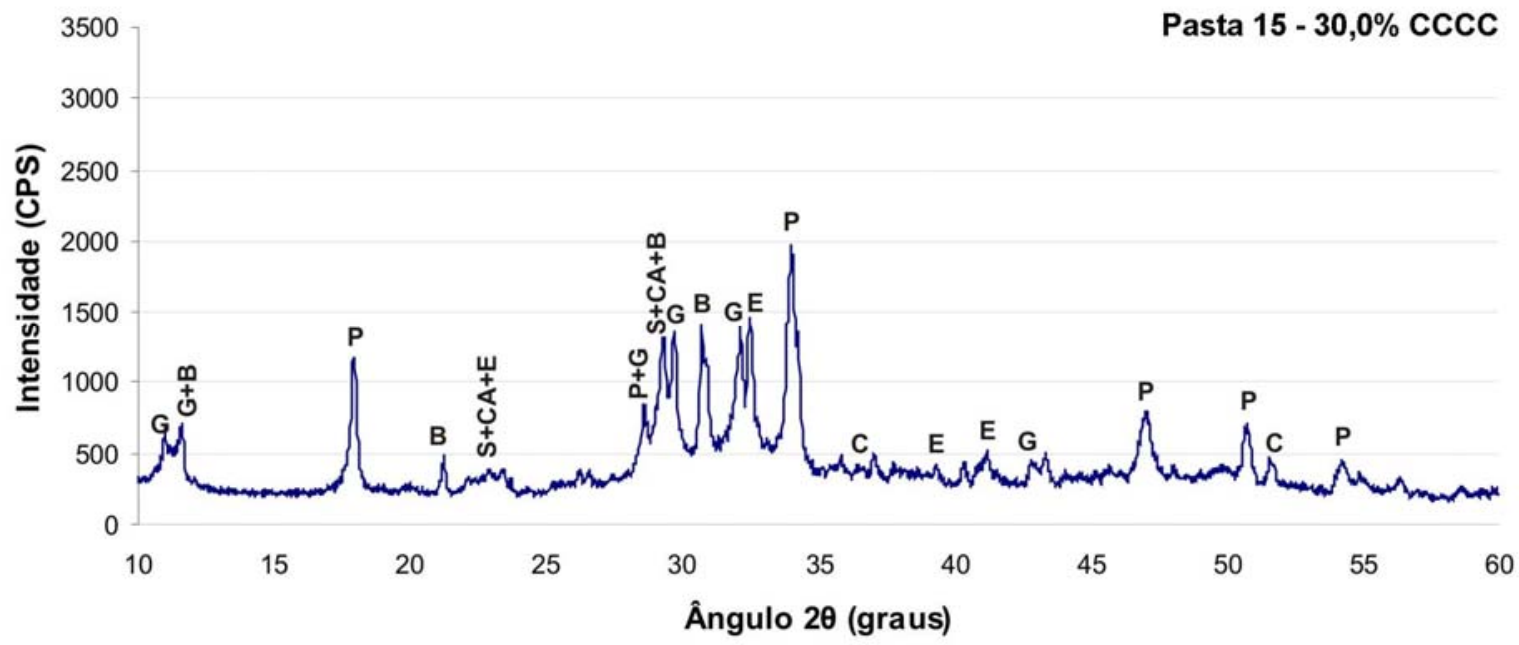

Figua 5.16 - Difratograma de raios X da Pasta 15

Esses minerais também foram identificados na CCCC in natura (Figura 5.4) e são formados, respectivamente, pelas espécies químicas Potássio e Fósforo, os principais formadores da CCCC. Não foram encontrados, na bibliografia consultada, estudos sobre a influência desses minerais em matrizes cimentícias.

\subsubsection{Influência da variação dos teores de substituição}

A avaliação do comportamento das argamassas, confeccionadas para análise da influência da variação dos teores de CCCC em substituição ao cimento Portland, foi verificada em duas etapas: estado fresco e estado endurecido. As propriedades observadas 
durante a execução do ensaio foram: i) tempo de trabalhabilidade; ii) massa específica no estado fresco; iii) teor de ar incorporado; iv) resistência à compressão.

\subsubsection{Argamassas no estado fresco}

Apesar da demanda de água, para a trabalhabilidade requerida pela norma NBR 5752 (ABNT, 1992), ter variado menos de $3 \%$ entre o valor do traço TRO $(0,590)$ e o do traço TR30 $(0,608)$, os valores das massas específicas no estado fresco (MEF) apresentaram variações de até $10 \%$. Os resultados encontram-se nas Figuras 5.15 e 5.16 . Os valores encontram-se melhor detalhados no Apêndice D.

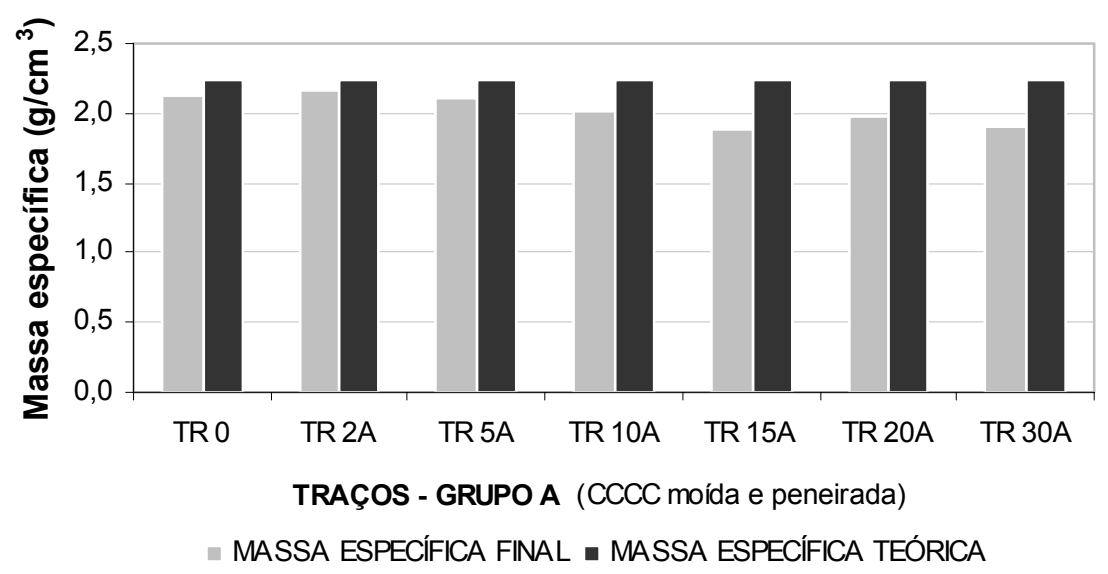

Figura 5.17 - Variação da massa específica final em relação a massa específica teórica amostras do grupo A (cinza moída e peneirada) em relação a amostra de referência (TR0)

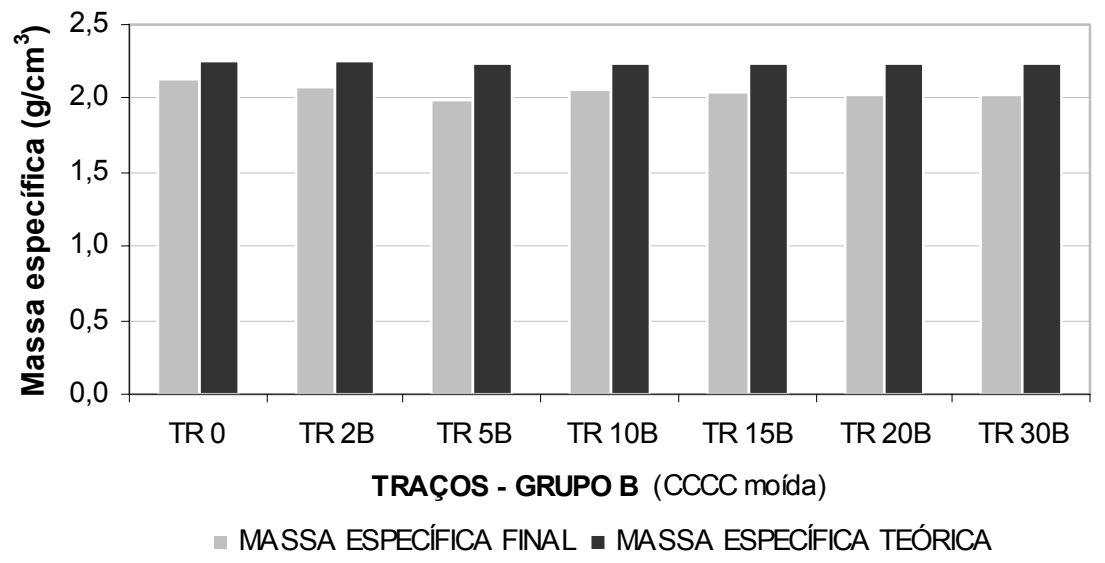

Figura 5.18 - Variação da massa específica final em relação a massa específica teórica - amostras do grupo B (cinza moída) em relação a amostra de referência (TR0)

A maior incorporação de ar (Figuras 5.19 e 5.20), porém, não alterou a trabalhabilidade (índice de consistência) das argamassas em estado fresco. No entanto, 
com o aumento do teor de cinza observou-se uma perda rápida de trabalhabilidade das argamassas, algumas vezes afetando a moldagem dos corpos-de-prova.

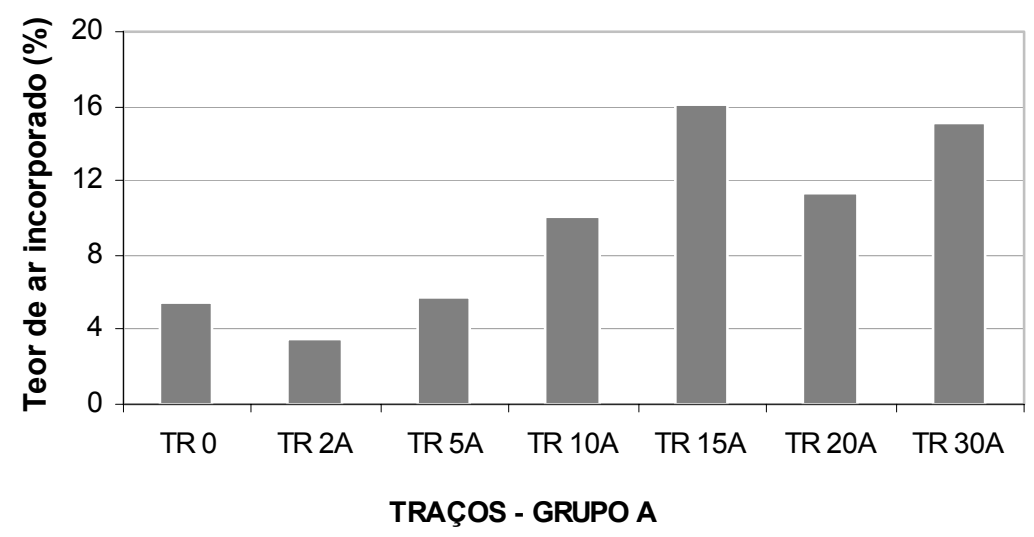

Figura 5.19 - Teor de ar incorporado - Grupo A

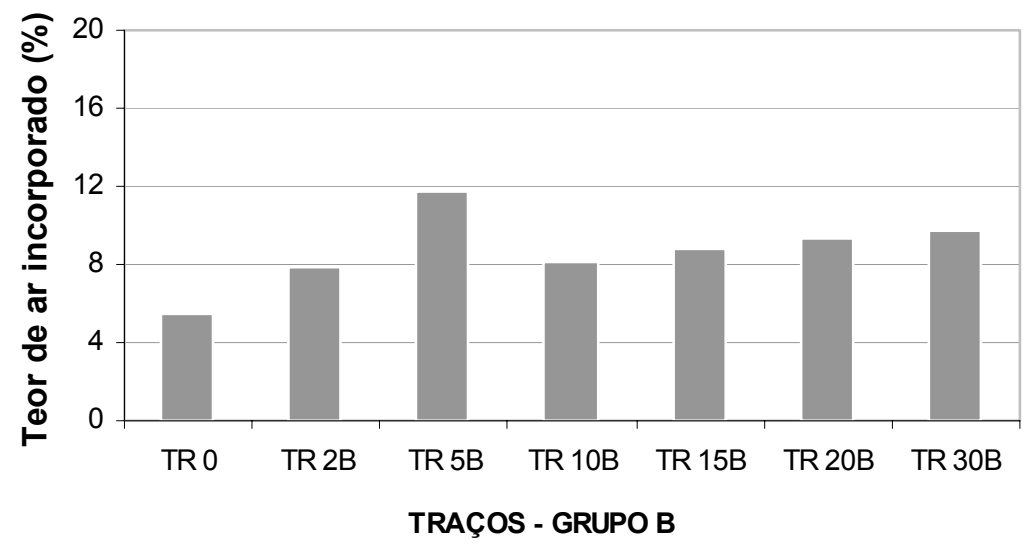

Figura 5.20 - Teor de ar incorporado - Grupo B

\subsubsection{Argamassas no estado endurecido}

Para análise da resistência à compressão foram moldados 5 (cinco) corpos-de-prova $(50 \times 100 \mathrm{~mm})$ de argamassa para cada traço. As idades analisadas foram 14, 28, 56 e 91 dias.

Analisando-se o desenvolvimento das resistências ao longo do tempo, verificou-se que a diferença entre a amostra padrão (TRO) e as demais, em geral, manteve-se constante (Figura 5.21 e 5.22), não tendo sido observados picos de crescimento nas maiores idades para as amostras que utilizaram CCCC. Tal fato é um forte indicativo da ausência de atividade pozolânica. Sabe-se que os materiais pozolânicos têm reatividade latente, 
ocasionando máximas resistências em idades avançadas (CINCOTTO, 1988; LAWRENCE, et al., 2005; CYR, et al., 2006).

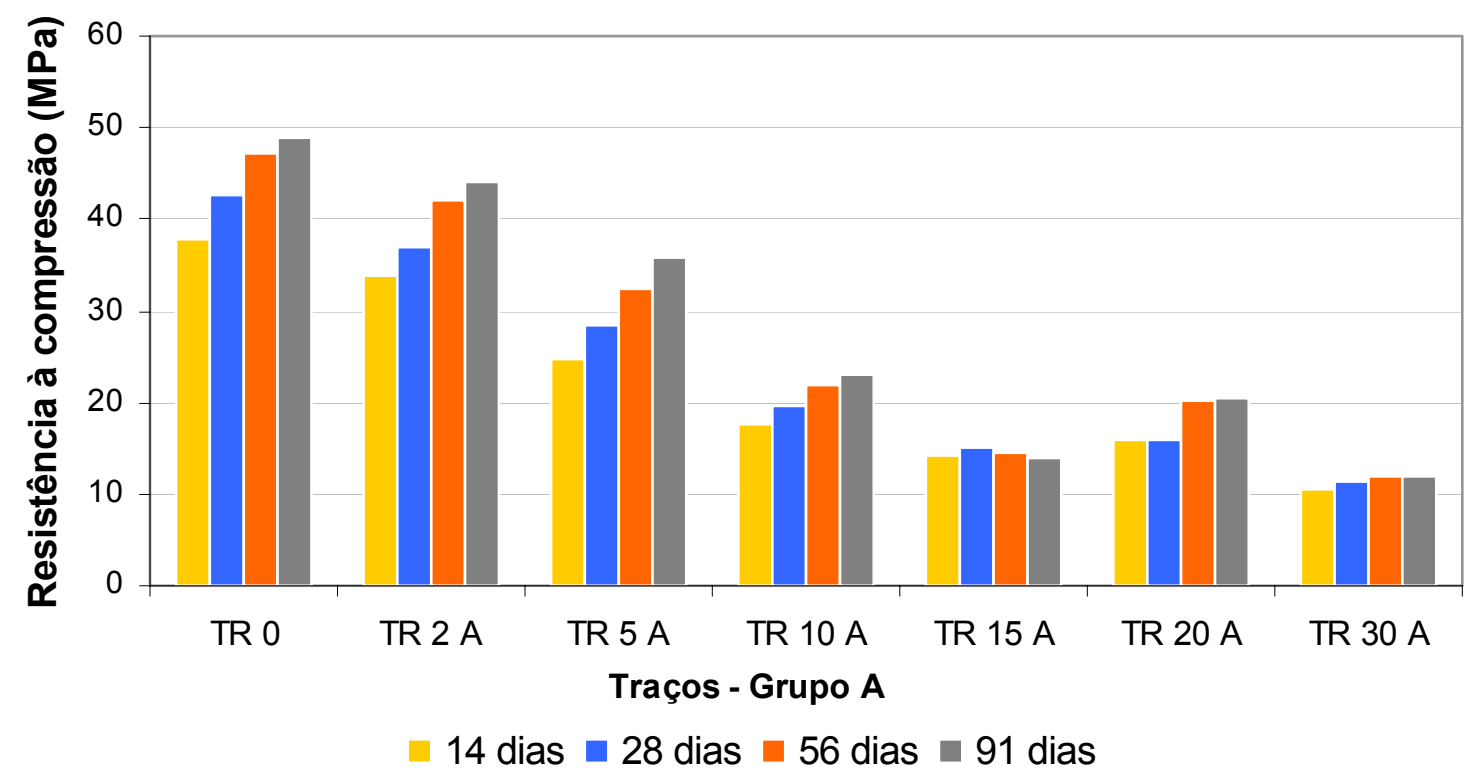

Figura 5.21 - Evolução da resistência à compressão em função dos teores de CCCC - Grupo A

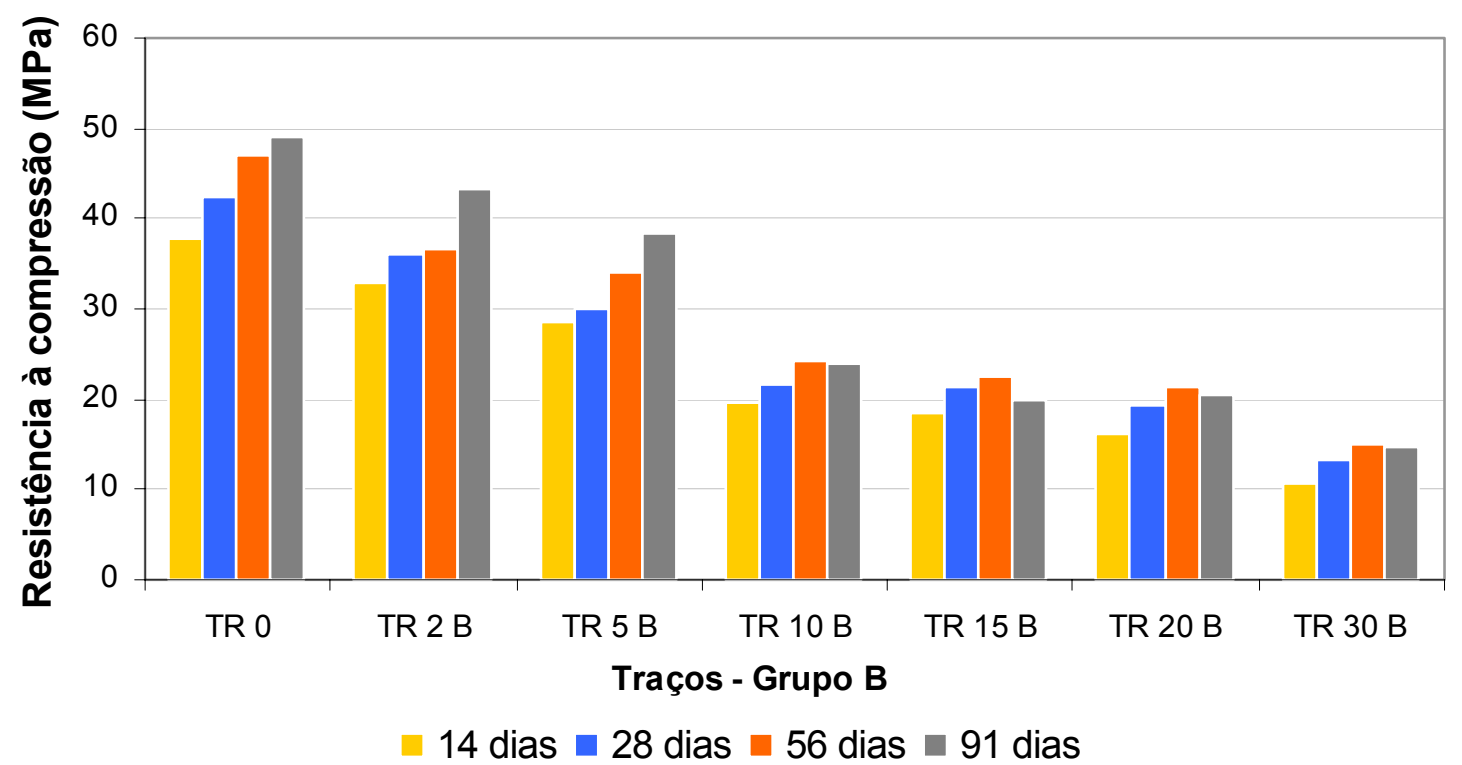

Figura 5.22 - Evolução da resistência à compressão em função dos teores de CCCC - Grupo B

Com os dados apresentados nas Figuras 5.21 e 5.22 pode-se afirmar, também, que a evolução no aumento dos valores das resistências apresenta-se semelhante nos grupos $\mathrm{A} e$ B. Com isso, não se observa diferença significativa entre os valores de resistência à 
compressão dos corpos-de-prova que utilizaram CCCC moída e peneirada (menor tamanho de grão), em relação aos que utilizaram material apenas moído.

Notou-se uma pequena evolução nos valores das resistências com teores de substituição até $10 \%$. Acima de $20 \%$ o ganho de resistência é mínimo ao longo do tempo, observando-se uma constância nos valores das resistências dos corpos-de-prova com 30\% de substituição.

Para melhor tratar os resultados, foram feitas análises por inferência estatística com valores de resistência à compressão, obtidos pelos corpos-de-prova confeccionados com substituição de CCCC por CP V ARI, nas condições estabelecidas por esta pesquisa. Os resultados apontam para uma hipótese de igualdade entre o traço com 2,5\% (TR2) de CCCC e a amostra de referência, apesar da diferença encontrada nos valores médios de resistência à compressão aos 91 dias de idade (Figura 5.23). Esse fato ocorre tanto para as amostras do grupo A quanto do grupo B. A análise por inferência estatística encontra-se detalhada no Apêndice $\mathbf{A}$.

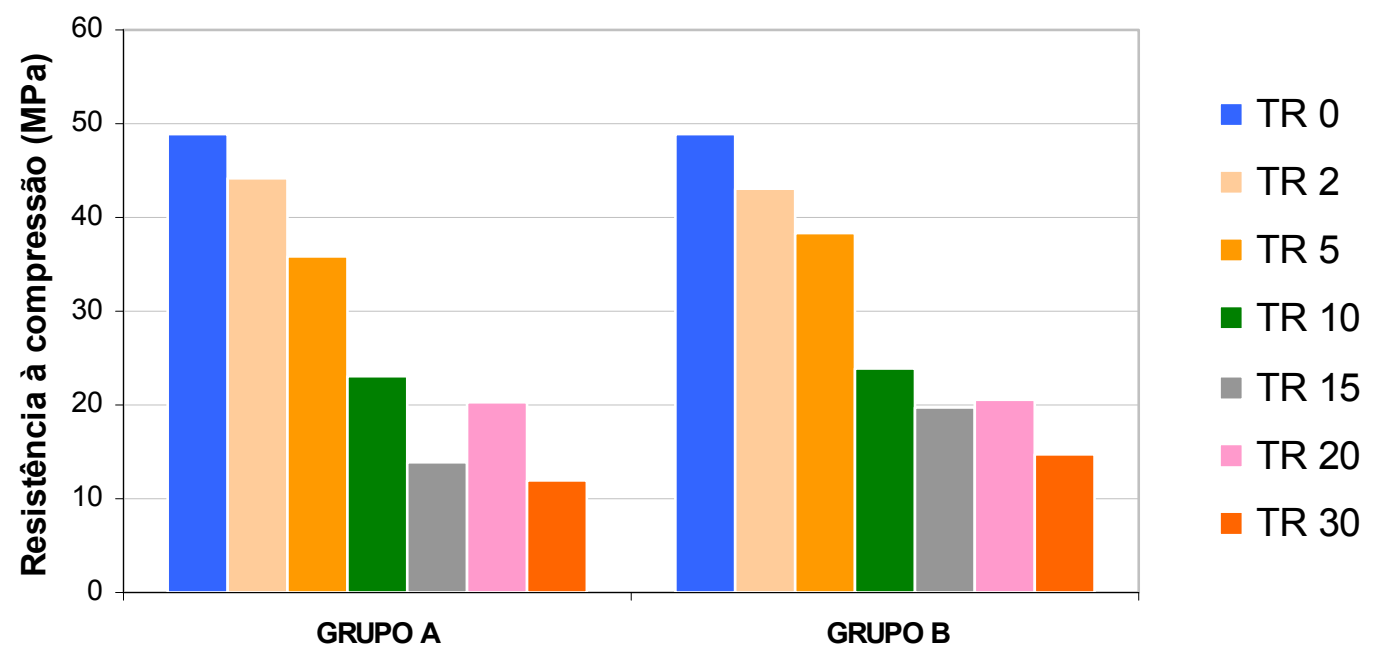

Figura 5.23 - Resistência à compressão média aos 91 dias dos grupos A e B

O valor de 2,5\%, portanto, pode ser apontado como o valor ótimo de substituição de CCCC dentre os teores analisados, com o qual não há prejuízo da resistência mecânica de argamassas moldadas com cimento CP V ARI.

No que se refere à baixa evolução de resistência à compressão dos demais traços, há que se levar em consideração os altos teores de incorporação de ar no estado fresco em alguns dos traços. Sabe-se que quanto maior a porosidade de um material, menor sua densidade e, conseqüentemente, menor a resistência à compressão do sistema. Segundo 
Mehta \& Monteiro (1994) para um dado fator água/cimento, a incorporação de ar reduz a resistência à compressão. Analisando esse exemplo em argamassas, segundo a Figura 5.24, para um mesmo fator água/cimento no valor de 0.60 , a resistência à compressão diminui de 26 para $19 \mathrm{MPa}$, aproximadamente, por causa da diferença no teor de ar incorporado.

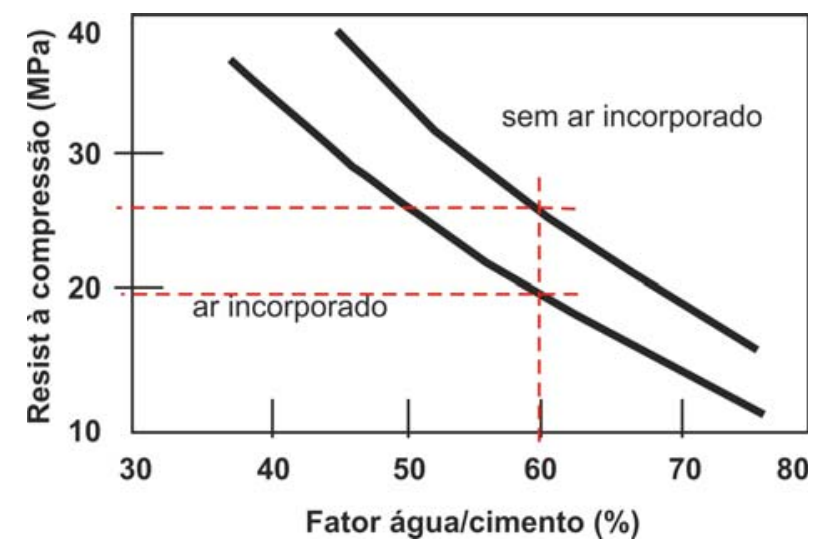

Figura 5.24 - Influência do fator água/cimento e do ar incorporado sobre a resistência à compressão. Fonte: Mehta \& Monteiro, 1994.

Para o traço com 15\% de CCCC pertencente ao Grupo A (cinza moída e peneirada) a incorporação de ar chegou a 16\%, mais de 3 vezes o valor observado para o traço de referência. De uma maneira geral os valores de ar incorporado foram maiores nos traços do Grupo A (cinza moída e peneirada) do que no Grupo B (cinza moída). Tal fato pode ser relacionado a maior finura do grão de $\mathrm{CCCC}$, no primeiro grupo.

Ainda que a CCCC não tenha contribuído de forma significativa para o efeito pozolânico e o ganho de resistência, ainda que tardio, o alto teor de incorporação de ar também foi determinante para os baixos valores de resistência à compressão encontrados nos traços com teor de substituição acima de $10 \%$. Ao baixo teor de sílica, somam-se a perda de trabalhabilidade no estado fresco e a incorporação de ar elevada, como fatores determinantes para os baixos valores de resistência à compressão encontrados por esta pesquisa. 


\subsection{Retração por secagem}

A NBR 12650 (ABNT, 1992) estabelece a determinação da retração por secagem devido à utilização de materiais pozolânicos por meio da análise de corpos-de-prova com a substituição do agregado miúdo por material pozolânico.

Neville (1997) afirma que a maior influência na retração deve ser creditada ao agregado, uma vez que a adição desse restringe a retração que deveria efetivamente ocorrer. Uma vez que para esse ensaio de retração houve a substituição de agregado miúdo (areia normal) por CCCC, tal mudança pode ter favorecido o pequeno aumento no valor da retração para o traço $\mathrm{N}$, denominado "controle". Portanto, não se podem desconsiderar os efeitos da diminuição do teor de agregado e aumento da CCCC na mistura "controle".

Os valores obtidos pelas leituras aos 7 e 28 dias, conforme exigido pela norma NBR 12650 (ABNT, 1992), são apresentados na Tabela 5.9.

Tabela 5.9 - Resultados - Ensaio NBR 12650/92

\begin{tabular}{lcc}
\hline $\mathrm{R}_{\mathrm{SE}}(\%)$ & $\mathrm{R}_{\mathrm{SC}}(\%)$ & $\mathrm{VR}_{\mathrm{S}}(\%)$ \\
\hline 0,11 & 0,16 & 0,05 \\
\hline $\mathrm{R}_{\mathrm{SE}}$ - retração média por & secagem das barras da mistura \\
"ensaio" - traço P (\%) & & \\
$\mathrm{R}_{\mathrm{SC}}$ - retração média por & secagem das barras da mistura \\
"controle" - traço N (\%) \\
VRS - variação da retração por secagem entre as barras da \\
mistura "ensaio" e "controle" (\%)
\end{tabular}

No entanto, a referida norma não estabelece parâmetros comparativos para esses resultados, não possibilitando uma análise correta sobre a estabilidade dimensional de corpos-de-prova de argamassas confeccionados com materiais pozolânicos.

Com isso, devido à ausência de informações comparativas, paralelamente às análises de retração segundo a norma supracitada, esta pesquisa determinou outros 12 (doze) traços com o intuito de verificar a influência do teor de substituição de CCCC na retração de corpos-de-prova de argamassas em várias idades. Esses traços foram divididos em 2 (dois) grupos, segundo o tratamento dado à CCCC, e analisados os valores de retração aos 14 , 28, 56 e 119 dias. Os resultados encontram-se nas Figuras 5.25 e 5.26. 


\section{Valores de Retração - Grupo B (CCCC moída)}

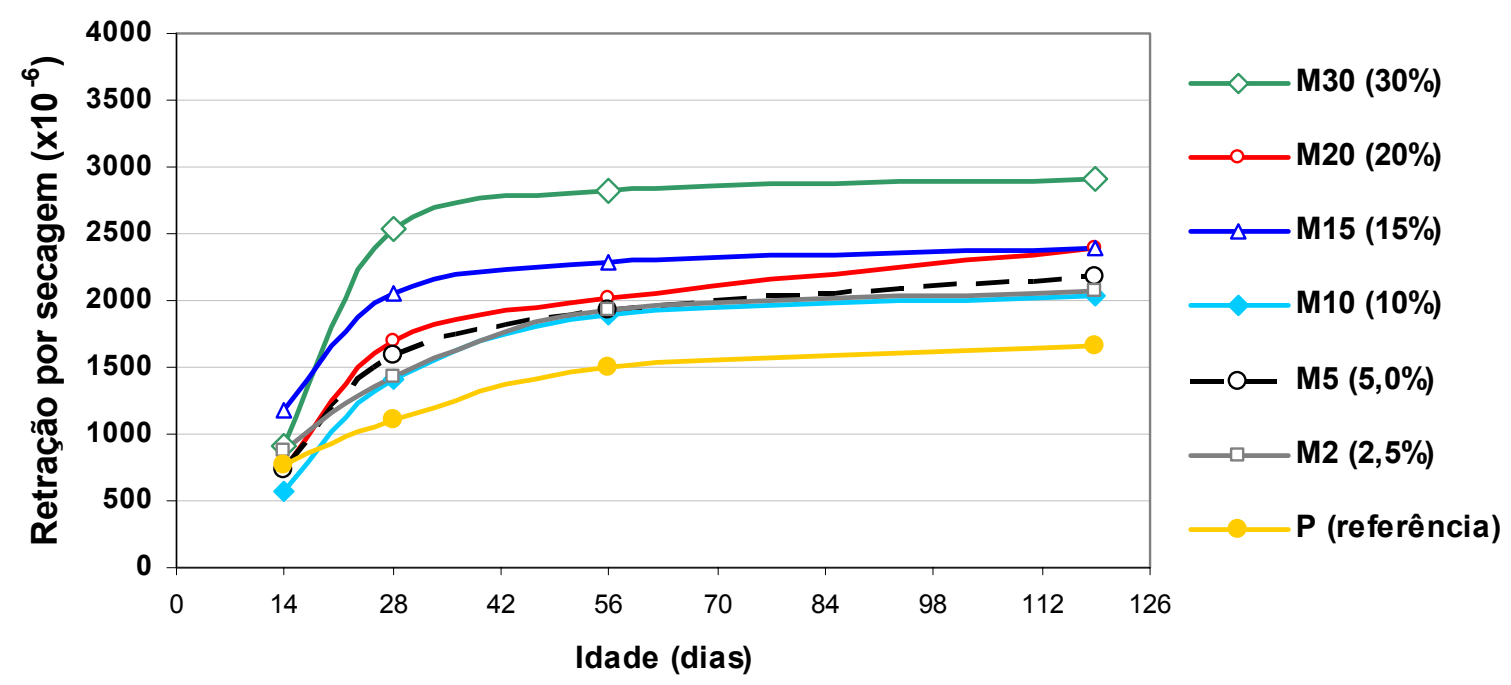

Figura 5.25 - Valores de retração $\left(\times 10^{6}\right)$ - Grupo B

\section{Valores de Retração - Grupo C (CCCC moída e peneirada)}

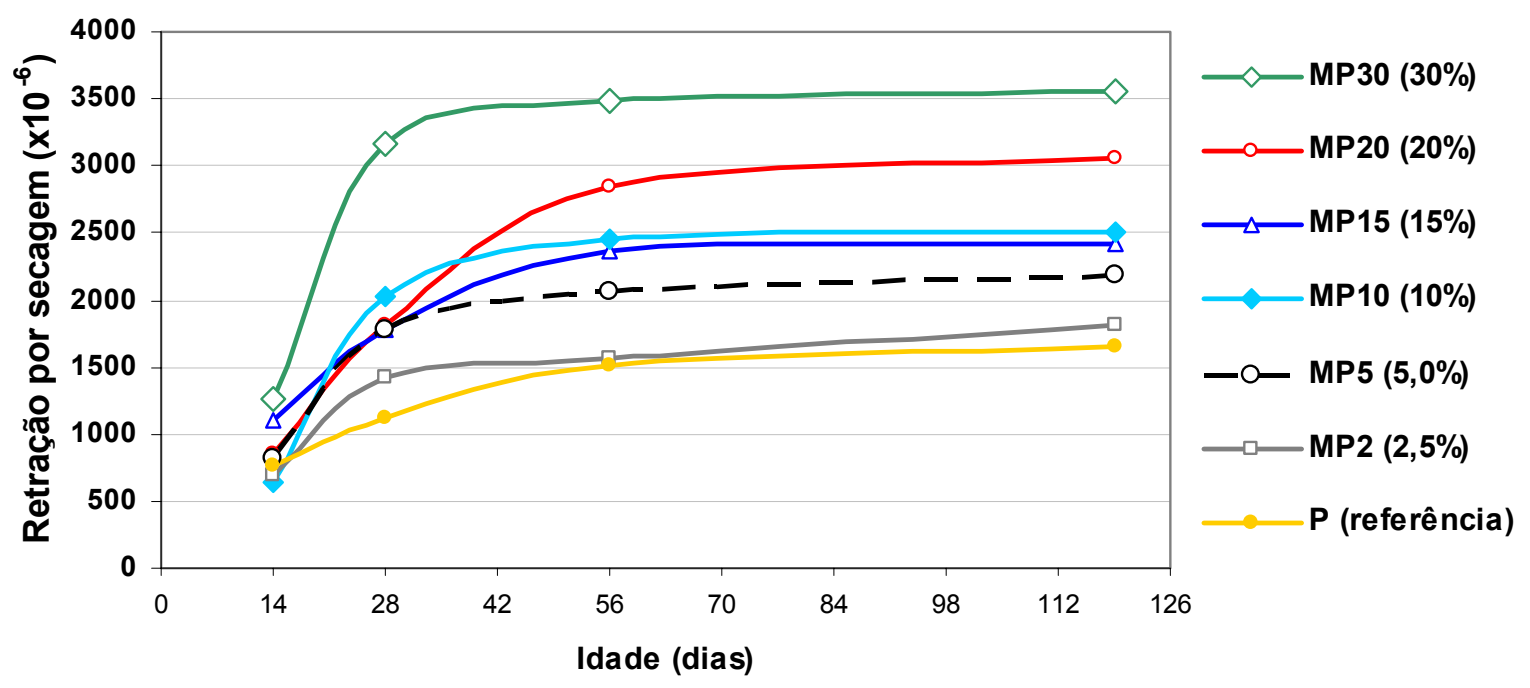

Figura 5.26 - Valores de retração $\left(\times 10^{6}\right)$ - Grupo C

Os resultados indicam que o aumento do teor de CCCC foi proporcional ao aumento dos valores de retração, até a idade de 56 dias, em ambos os grupos. No grupo $C$, onde a CCCC foi moída e peneirada, os valores da retração dos traços MP10, MP15, MP20 e MP30 foram superiores aos respectivos traços encontrados no grupo B. Tal fato pode ser devido a maior finura da cinza utilizada nesses traços. Sabe-se que variações na finura e composição do cimento Portland tendem a influenciar o comportamento da retração por secagem de 
pequenos corpos-de-prova de pasta de cimento ou de argamassa (MEHTA \& MONTEIRO, 1994).

Melo Neto et al. (2008) estudaram a retração do cimento de escória ativada (CEA), após utilização de vários ativadores, e constataram que a retração do CEA foi maior que a do cimento Portland e que grande parte desse fenômeno ocorreu até os 7 dias.

A retração por secagem apresenta-se muito mais elevada nos traços confeccionados com CCCC, principalmente em pequenas idades. Para o grupo B, o traço M30 apresenta valores de retração, aos 56 dias, superior em $87 \%$ em relação ao traço controle. No grupo $C$ essa mesma diferença fica em mais de $130 \%$.

Apesar do expressivo aumento dos valores de retração até os 28 dias, após esse período torna-se clara a tendência de estabilização em todos os traços de ambos os grupos. Os corpos-de-prova confeccionados com altos teores de CCCC (acima de 15\%) apresentaram elevado teor de ar incorporado (item 5.9), fato que pode ter sido determinante para os altos valores de retração por secagem das amostras analisadas.

\subsection{Profundidade de carbonatação}

Considerando-se que o elevado teor de incorporação de ar, observado nos corpos-deprova com substituição parcial de cimento Portland por CCCC,mostrou-se importante a avaliação da profundidade de carbonatação em corpos-de-prova com adição de teores variados de CCCC.

De acordo com RILEM ${ }^{30}$ (1988) apud Silva (2007), a carbonatação é definida "como a neutralização da fase líquida intersticial de hidróxido de cálcio, e de outros compostos alcalinos hidratados, presentes na pasta de cimento, pelo agente dióxido de carbono $\left(\mathrm{CO}_{2}\right)$ ".

Uma vez que a relação água/cimento é responsável pela determinação do tamanho, quantidade e continuidade dos poros presentes na matriz cimentícia, reduzindo-se essa relação, há uma diminuição da profundidade de carbonatação (SILVA, 2007). Segundo

${ }^{30}$ RILEM Concrete Permanent Commitee CPC-18. (1984). Measurement of hardened concrete carbonation depth. Matériaux et Constructions. Vol. 17, $\mathrm{n}^{\circ} 102$. 
Hobbs $^{31}$ (1999) apud Silva (2007) o fator água/cimento interfere significativamente na porosidade e permeabilidade da profundidade de carbonatação.

Para a análise da influência do uso da CCCC no teor de carbonatação de matrizes cimentícias, foram moldados 2 (dois) corpos-de-prova para cada amostra, a serem analisados aos 90 e 180 dias. As amostras do Grupo A foram confeccionadas com teores de CCCC entre 2,5 e $30 \%$, sendo essa moída durante 1 (uma) hora no moinho de bolas. 0 Grupo B obteve o mesmo tratamento do grupo anterior, com a diferença de que a CCCC foi passada na peneira $\mathrm{n}^{\circ} 200$ (abertura $0,075 \mathrm{~mm}$ ), após a moagem, sendo utilizado apenas 0 material passante.

Após o contato com a fenolftaleína, torna-se bastante visível a carbonatação dos corpos-de-prova confeccionados com CCCC (Apêndice E). Em alguns exemplares essa carbonatação ocorre inclusive no interior das amostras (traços M30 e MP30). Tal fato pode ser devido ao alto teor de ar incorporado, aferido no estado fresco, em argamassas com CCCC em substituição ao cimento Portland.

Sabe-se que a reação pozolânica das adições minerais tem grande importância na diminuição no avanço da carbonatação exemplares confeccionados com cimento Portland. Algumas pesquisas com a cinza volante (HO \& LEWIS, 1983; BYFORS, 1985) mostraram que os concretos confeccionados com essa adição mineral tiveram um maior avanço da carbonatação quando comparados aos exemplares de referência. A profundidade de carbonatação aumentou na mesma proporção do teor de cinza volante e do ar incorporado nas amostras.

Processo semelhante ocorreu com as argamassas contendo CCCC. Os resultados das análises da profundidade de carbonatação encontram-se nas Figuras 5.27 e 5.28.

Pode-se observar que a substituição de cimento Portland por CCCC em 30\% aumentou mais de 3 (três) vezes a profundidade de carbonatação aos 90 e aos 180 dias, em ambos os grupos. Em teores menores (até $10 \%$ de substituição), a profundidade de carbonatação também se mantém elevada, chegando a valores quase 3 (três) vezes maiores que o da amostra de referência, aos 90 dias.

${ }^{31}$ HOBBS, D. W. (1988). Carbonation of concrete containing pfa. Magazine of Concrete Research. v. 40, n. 143, p. 69-78. 


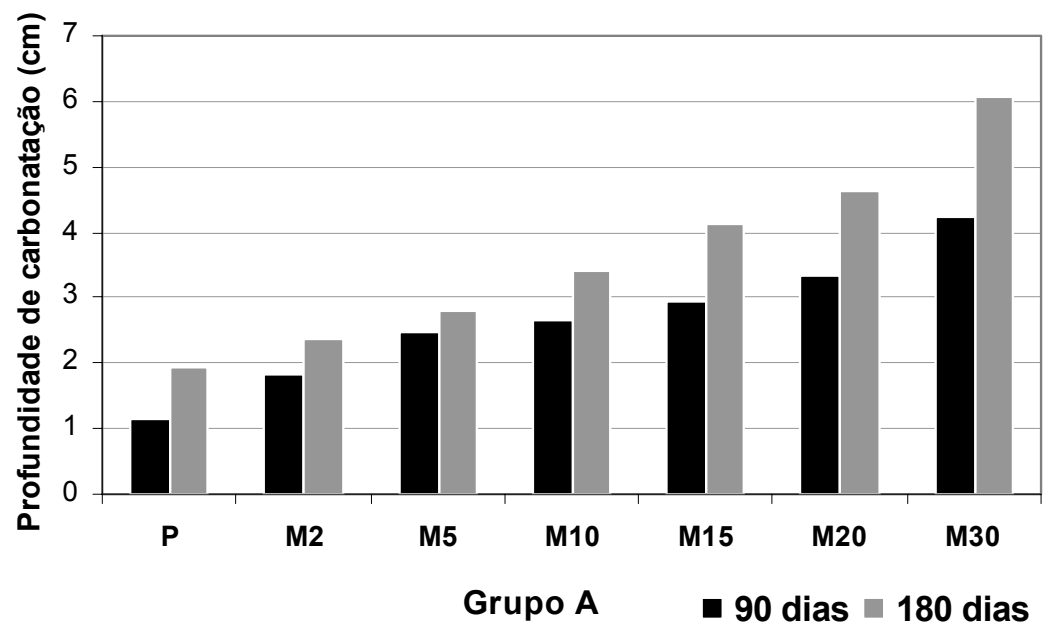

Figura 5.27 - Valores da profundidade de carbonatação - Grupo A (cinza moída)

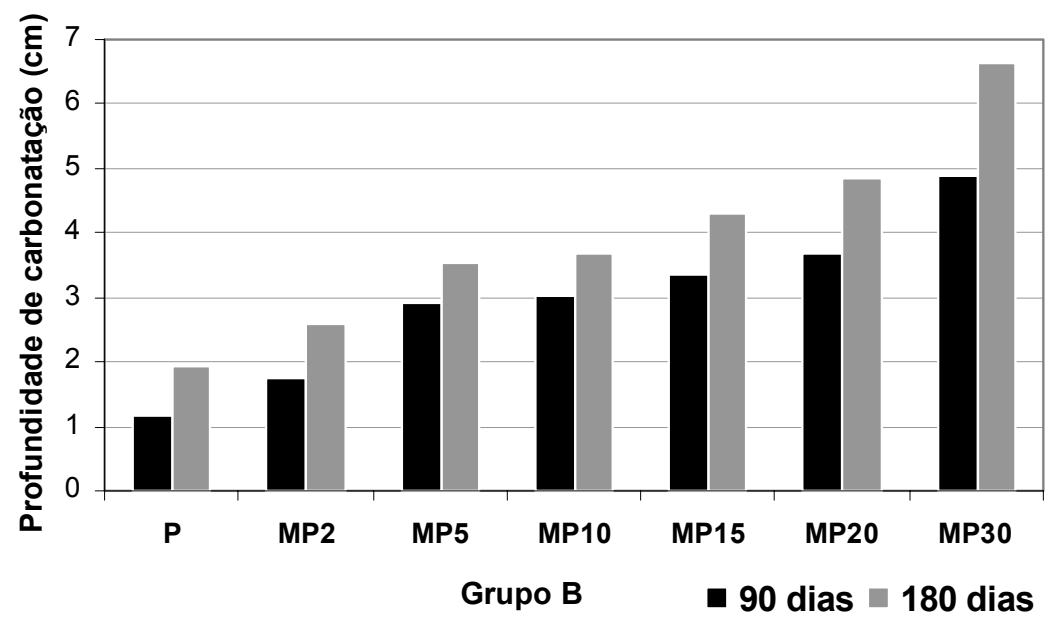

Figura 5.28 - Valores da profundidade de carbonatação - Grupo B (cinza moída e peneirada)

A porosidade da matriz sofre alterações ao longo do tempo, sob o efeito da carbonatação, pois o volume molar da Calcita é maior que o da Portlandita (GERVEN et al., 2007). Sendo assim, a velocidade de carbonatação tende a diminuir com o tempo, por conta do fechamento dos poros provocado pelas próprias reações químicas da carbonatação.

Nota-se, também, que a carbonatação foi maior nas amostras do Grupo B, o que pode ter sido provocado pela maior finura da CCCC. Para esse grupo, pode-se observar maior demanda de água e um maior teor de ar incorporado no estado fresco (Figuras 5.19 e 5.20). Como no ensaio de carbonatação a relação a/c foi mantida constante, a trabalhabilidade apresentou-se menor nas amostras do Grupo B.

Atis (2004) estudou a cinza volante e estabeleceu uma relação entre porosidade, carbonatação e resistência à compressão e observou que quanto maior a resistência à 
compressão, menor a profundidade de carbonatação e menor a porosidade (Figura 5.29). Esse estudo confirma o fenômeno que ocorreu nos corpos-de-prova moldados com a CCCC, no qual o teor de ar incorporado no estado fresco pode ter contribuído para a porosidade no estado endurecido, facilitando o avanço da frente de carbonatação. Ao aumento do teor de CCCC em substituição ao cimento Portland, seguiu-se a diminuição da resistência à compressão e o aumento e da porosidade (Item 5.2.3 - Influência da variação dos teores de substituição) e da profundidade de carbonatação.

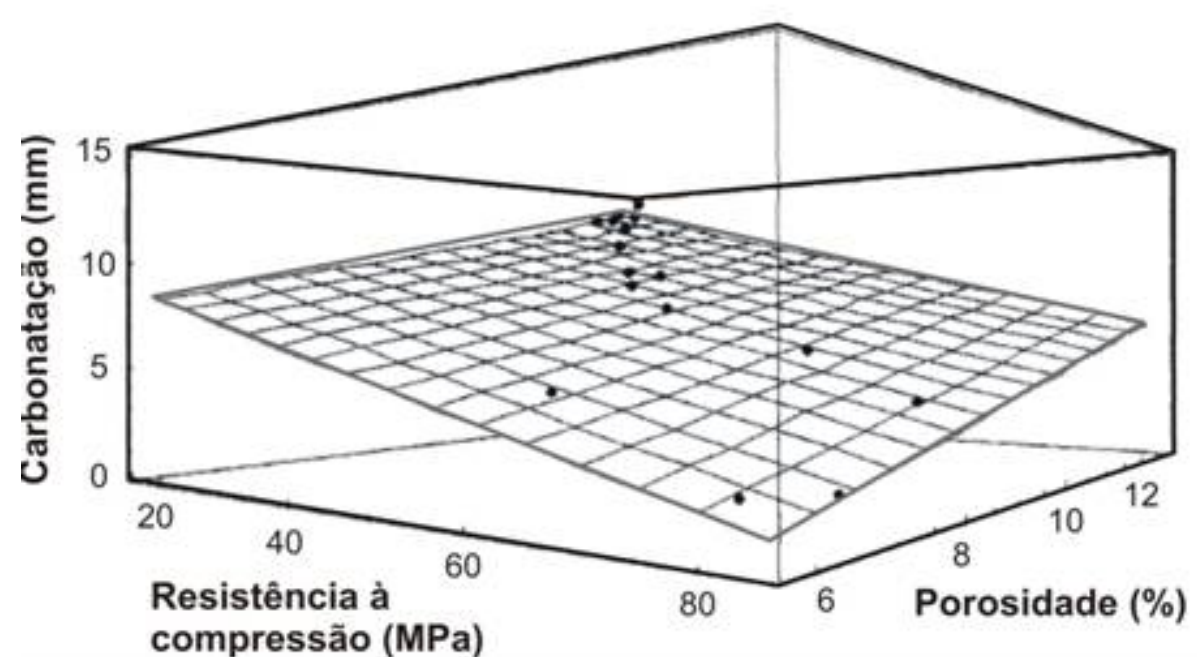

Figura 5.29 - Esquema tridimensional da relação entre carbonatação, resistência à compressão e porosidade em concretos. Fonte: Atis, 2004 (adaptado)

\subsection{Estabilização/solidificação da CCCC pela matriz cimentícia}

Pelas análises do extrato solubilizado, segundo a norma NBR 10006 (ABNT, 2004), foram encontrados vários metais pesados na amostra de CCCC in natura, sendo a CCCC classificada como Resíduo Não perigoso - Classe II A - Não inerte. Pela norma NBR 10004 (ABNT, 2004) os resíduos com tal classificação podem ter propriedades de biodegradabilidade, combustibilidade ou solubilidade em água.

Rocha \& Cheriaf (2003) atentam para a necessidade de identificação do que denominam "Parâmetros Ambientais", indispensável quando da manipulação de resíduos em materiais de construções, citando como exemplo o ensaio adaptado de materiais. Por esse fato, a análise da capacidade de Estabilização/Solidificação (S/S) da CCCC pela matriz cimentícia apresentou-se de grande importânica. 
Neste ensaio, pretende-se simular o britamento de materiais de construção (blocos, telhas, etc.) confeccionados com a CCCC, caso esses sejam submetidos a demolição no futuro, determinando a capacidade de retenção desse resíduo pela matriz cimentícia quando depositados em aterro sanitário e exposto às intempéries.

A Tabela 5.10 apresenta os metais pesados encontradas no extrato solubilizado das pastas no estado endurecido pós-britagem com teores variados de CCCC.

Tabela 5.10 - Valores acima do limite máximo permitido pela NBR 10006 - substâncias encontradas nas pastas e na CCCC in natura

\begin{tabular}{|c|c|c|c|c|c|c|c|}
\hline \multirow{3}{*}{ Parâmetro } & \multirow{3}{*}{ Unidade } & \multicolumn{5}{|c|}{ Valores encontrados * } & \multirow{3}{*}{$\begin{array}{c}\text { Limite máximo } \\
\text { permitido no } \\
\text { extrato (mg/L) }\end{array}$} \\
\hline & & \multirow{2}{*}{$\begin{array}{c}\text { CCCC in } \\
\text { natura }\end{array}$} & \multicolumn{4}{|c|}{ Pastas - \% CCCC utilizada } & \\
\hline & & & $0 \%$ & $2,5 \%$ & $5,0 \%$ & $10,0 \%$ & \\
\hline Alumínio & $\mathrm{mg} \mathrm{Al} / \mathrm{L}$ & 0,12 & 0,14 & 0,16 & 0,18 & 0,25 & 0,20 \\
\hline Cádmio & $\mathrm{mg} \mathrm{Cd} / \mathrm{L}$ & 0,57 & $<$ LD & $<$ LD & $<$ LD & $<$ LD & 0,005 \\
\hline Chumbo & $\mathrm{mg} \mathrm{Pb/L}$ & 1,39 & $<$ LD & $<$ LD & $<$ LD & $<$ LD & 0,01 \\
\hline Cloretos & $\mathrm{mg} \mathrm{Cl} / \mathrm{L}$ & 950,00 & 2 & 14 & 42 & 100 & 250,00 \\
\hline Cromo Total & $\mathrm{mg} \mathrm{Cr} / \mathrm{L}$ & 3,09 & 0,25 & 0,93 & 0,25 & 0,67 & 0,05 \\
\hline Fenóis Totais & $\mathrm{mg} \mathrm{C}_{6} \mathrm{H}_{5} \mathrm{OH}$ & 0,042 & $<$ LD & $<$ LD & $<$ LD & $<$ LD & 0,01 \\
\hline Ferro Total & $\mathrm{mg} \mathrm{Fe} / \mathrm{L}$ & 1,68 & 0,10 & 0,10 & 0,12 & 0,18 & 0,30 \\
\hline Fluoreto & $\mathrm{mg} \mathrm{F}^{-} / \mathrm{L}$ & 0,12 & 1,04 & 1,25 & 1,31 & 1,51 & 1,50 \\
\hline Manganês & $\mathrm{mg} \mathrm{Mn/L}$ & 0,21 & $<$ LD & $<$ LD & $<$ LD & 0,01 & 0,10 \\
\hline Nitratos & $\mathrm{mg} \mathrm{N} / \mathrm{L}$ & 75,0 & 0,65 & 1,11 & 2,43 & 4,87 & 10,00 \\
\hline Prata & $\mathrm{mg} \mathrm{Ag/L}$ & 0,62 & $<$ LD & $<$ LD & 0,01 & 0,02 & 0,05 \\
\hline Sódio & $\mathrm{mg} \mathrm{Na} / \mathrm{L}$ & 12175 & 457 & 506 & 895 & 1328 & 200 \\
\hline
\end{tabular}

$\left({ }^{*}\right)$ Valores em Negrito - Valores acima do limite máximo no extrato.

Comparando-se com os resultados obtidos no ensaio de solubilização da CCCC in natura, notou-se a diminuição da concentração de vários elementos e substâncias químicas. Os parâmetros para Cádmio, Chumbo, Cloretos, Fenóis totais, Ferro total, Manganês, Nitratos e Prata ficaram abaixo do limite máximo exigido para o extrato solubilizado das pastas confeccionadas com teores variados de CCCC. Sendo assim, a matriz cimentícia apresentou-se como eficaz na diminuição ou anulação da concentração desses elementos e substâncias, segundo ensaio de solubilização (NBR 10006/04).

No entanto, outros elementos se sobressaíram na análise das pastas, como a espécie química Alumínio e o ânion Fluoreto, que não haviam sido detectados nas análises da CCCC in natura (Tabela 5.11), mas que apareceram na pasta com teor de $10 \%$ de CCCC 
em valores um pouco acima do máximo permitido para os parâmetros de solubilização. A origem desses elementos pode ser creditada à matriz cimentícia (água e/ou cimento), uma vez que também são detectados no extrato solubilizado da pasta de referência $(0 \%$ de substituição).

Para o Cromo total e o Sódio houve diminuição na concentração do extrato das pastas em relação ao da CCCC in natura, ainda que não se possa desconsiderar os baixos teores de CCCC aplicados nas pastas (de 0\% a 10\%). Mesmo assim, os valores (em $\mathrm{mg} / \mathrm{L}$ ) do Sódio e do Cromo total ainda ficaram acima do limite máximo permitido para o extrato solubilizado, segundo as Figuras 5.30 e 5.31.

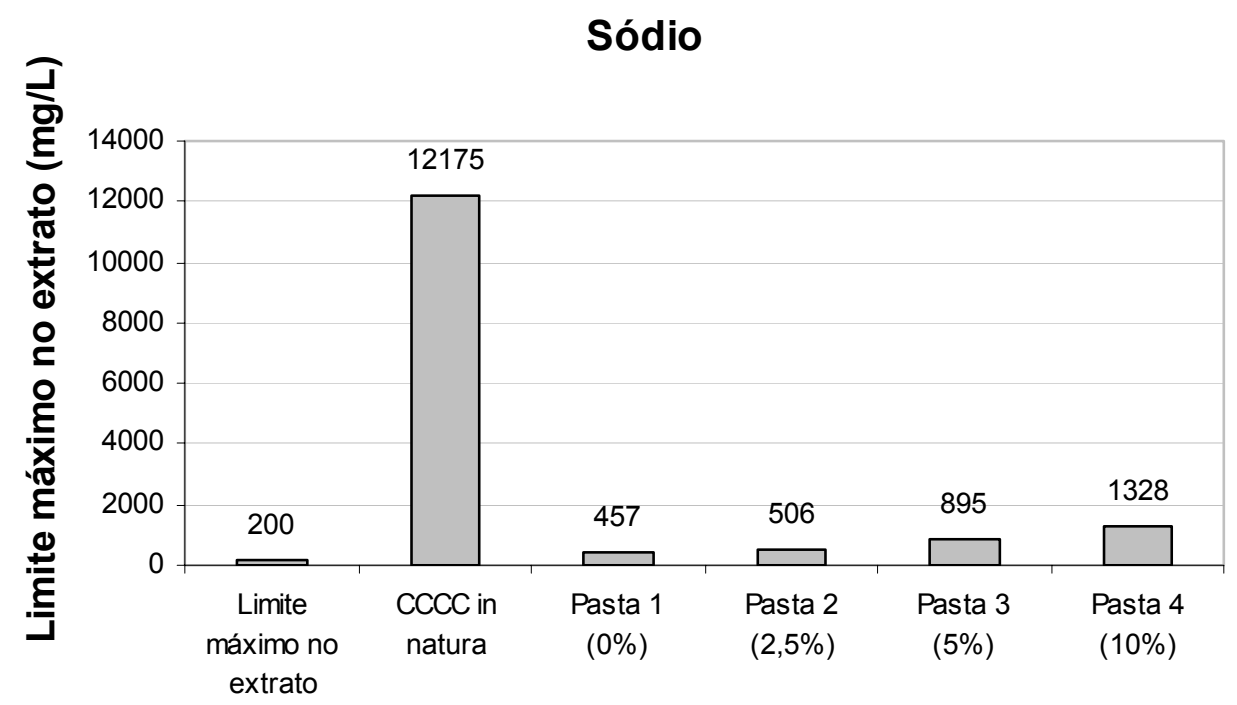

Figura 5.30 - Concentração no extrato solubilizado - Sódio

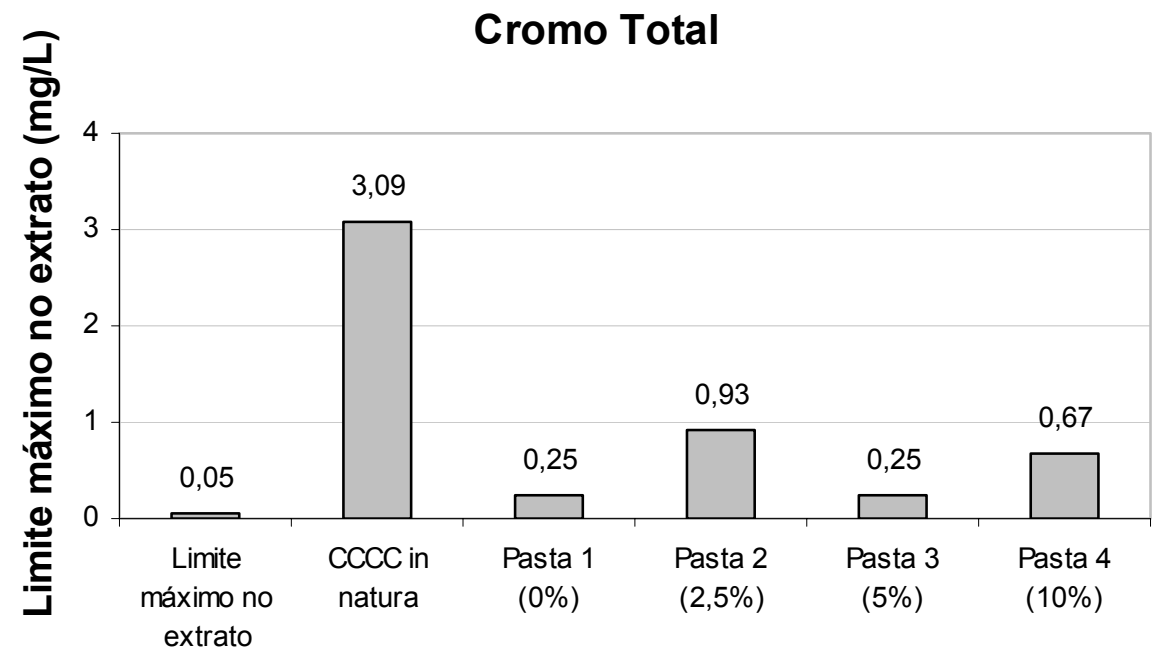

Figura 5.31 - Concentração no extrato solubilizado - Cromo Total

Em relação ao Sódio, a Pasta 1 (0\% CCCC) apresentou concentração desse material 2 vezes maior do que o limite máximo permitido no extrato. Tal fato aponta para um teor 
elevado de sódio no cimento utilizado nos ensaios, uma vez que a Pasta 1 foi confeccionada sem CCCC. O aumento da concentração de sódio da Pasta 2 em relação à Pasta 1 ficou em aproximadamente $10 \%$.

Para a substância Cromo, a diminuição na concentração foi significativa, entre os valores observados na CCCC in natura e encapsulada (Pasta 3), de aproximadamente $70 \%$. Porém, em todas as amostras (cinza e pastas), os valores encontrados ficaram acima do limite máximo permitido no extrato solubilizado pela norma NBR 10006 (ABNT, 2004). Foi observado que os valores das concentrações de Cromo nas pastas confeccionadas com CCCC não aumentaram de forma linear. Esse resultado se assemelha ao ocorrido em outros ensaios utilizando a cinza da casca da castanha de caju ${ }^{32}$.

A pasta confeccionada apenas com cimento Portland também apresentou concentração de Cromo no extrato solubilizado acima do limite máximo permitido por norma, o que leva-se a presumir que o cimento também pode estar contaminado com Cromo. Sabe-se que as fábricas de cimento, atualmente, queimam pneus inservíveis e outros resíduos para obter energia nos fornos de clínquer (TREZZA \& SCIAN, 2007).

Salienta-se, porém, que foi realizado apenas um ensaio para cada pasta e que ainda não existem normas brasileiras específicas que normatizem os parâmetros ambientais a serem exigidos aos resíduos com finalidade de aplicação na construção civil.

Por tais resultados, tem-se que a matriz cimentícia não foi eficaz na estabilização/solidificação do Cromo e do Sódio, mas que essas substâncias também foram detectadas, em valores acima do limite máximo permitido, no extrato solubilizado da pasta confeccionada apenas com cimento Portland.

\footnotetext{
${ }^{32}$ No ensaio de resistência à compressão (teores $\mathrm{x}$ resistência) também foi observado uma descontinuidade dos valores, criando zonas de "ruído" entre as porcentagens $5 \%$ e $20 \%$ de substituição do cimento Portland pela CCCC (APÊNDICE D).
} 


\section{Capítulo}

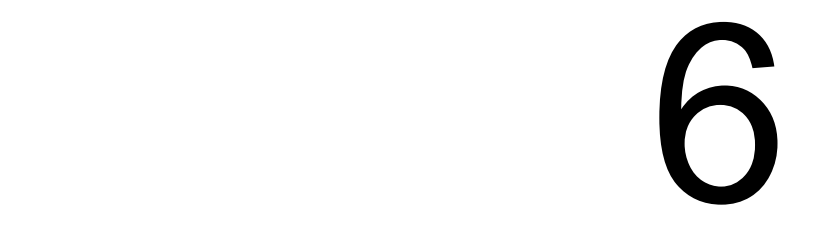

CONSIDERAÇÕES FINAIS

Esta pesquisa apresenta o estudo inicial sobre a viabilidade técnica do uso da cinza da casca da castanha de caju (CCCC) como adição mineral em matrizes cimentícias. De acordo com a revisão bibliográfica inicial foram definidas as etapas da pesquisa, bem como a metodologia a ser utilizada.

As análises tiveram como objetivo, primeiramente, investigar as características físicas e químicas da CCCC, uma vez que se trata de um subproduto ainda não estudado anteriormente como adição mineral para materiais cimentícios. Na etapa seguinte, definidos os parâmetros de caracterização, foram iniciados os estudos de pozolanicidade, retração e carbonatação utilizando corpos-de-prova de argamassa.

Com essas análises, pode-se fazer uma melhor avaliação sobre o teor ótimo de substituição do cimento Portland pela CCCC sem que houvesse prejuízos de ordem mecânica, microestrutural ou de durabilidade da matriz cimentícia. A última etapa do desenvolvimento experimental consistiu na análise da capacidade de estabilização/solidificação da CCCC pela matriz cimentícia, tendo em vista os resultados observados nos ensaios de solubilização de acordo com a norma NBR 10006 (ABNT, 2004).

Com o conjunto de informações obtidas, pode-se apontar como características principais da CCCC:

i) Não apresentar potencial pozolânico em matrizes cimentícias;

ii) Favorecer a incorporação de ar em matrizes cimentícias;

iii) Ocasionar solubilidade de metais pesados e Fenol, principalmente quando no estado in natura;

iv) Contribuir para o aumento da retração por secagem em argamassas;

v) Acelerar o processo de carbonatação em argamassas; e, 
vi) Liberar Cromo e Sódio mesmo quando estabilizada/solidificada em pastas em teores de até $10 \%$ de substituição;

Há, no entanto, a indicação de substituição do cimento Portland por CCCC no valor de 2,5\% em massa, segundo as análises de resistência à compressão de corpos-de-prova de argamassa. Contudo, tendo em vista o alto teor de contaminantes presente no extrato solubilizado da CCCC in natura e considerando as demais características até então levantadas, (aumento da retração e da carbonatação em argamassas, o favorecimento da incorporação de ar e a liberação de cromo e sódio mesmo estabilizada/solidificada em pastas), a CCCC não apresentou viabilidade técnica para uso em matrizes cimentícias.

Entretanto, há a possibilidade de utilização de matrizes dessa natureza para aplicação da técnica S/S no pós-tratamento da CCCC, já que se trata de um material potencialmente perigoso ao meio ambiente, não podendo ser descartado em aterros sanitários comuns.

Salenta-se, ainda assim, a importância desse trabalho em relação ao tratamento ambiental dispensado às cinzas agroindustrais utilizadas por meio da reciclagem na construção civil. A maior parte das aplicações desses resíduos toma em consideração apenas os aspectos tecnológicos em detrimento dos parâmetros de durabilidade e de contaminação, fato que pode comprometer os novos materiais gerados por essas pesquisas. Quando não se apropria de uma análise de viabilidade técnica mais ampla, que considere até mesmo os aspectos ambientais, pode-se correr o risco de se criar novos materiais com boas características imediatas, mas com baixa durabilidade ao longo do tempo.

A seguir apresenta-se uma análise objetiva dos resultados obtidos por esta pesquisa, em relação, especificamente, ao estudo da cinza da casca da castanha de caju.

\subsection{Caracterização física e química}

Pela análise química da CCCC observou-se o baixo teor de sílica $\left(\mathrm{SiO}_{2}\right)$, importante constituinte para a determinação inicial do potencial pozolânico.

Os altos teores de álcalis $\left(\mathrm{Na}_{2} \mathrm{O}+\mathrm{K}_{2} \mathrm{O}=18,02 \%\right)$ e de óxido de magnésio ( $\mathrm{MgO}=$ $16,34 \%$ ) encontrados restringem o uso de CCCC em teores elevados em matrizes cimentícias. 
Em relação aos níveis de contaminação, a análise do extrato solubilizado da CCCC apresentou vários tipos de metais pesados e Fenol. A origem desses metais, muito provavelmente, pode estar nos agrotóxicos utilizados no cajueiro. Já o fenol provém do LCC (líquido da casca da castanha do caju), material viscoso composto por cardol, cardanol e metilcardol, todos compostos químicos fenólicos.

Por não ter sido encontrado nenhum componente acima do limite máximo permitido no extrato lixiviado, de acordo com a NBR 10005, a CCCC classifica-se como resíduo Não Perigoso Classe II - A (Não inerte). Mesmo com esse resultado prévio, outros estudos devem ser feitos para que se possa ter a indicação precisa quanto à origem e a periculosidade desses elementos presentes na CCCC antes de uma classificação definitiva.

Pela análise do tempo de moagem da CCCC, pôde-se observar que o aumento no tempo de moagem proporcionou o aumento na finura da cinza. Ainda por esse ensaio ficou comprovado que essa variação da finura não influenciou nos resultados de resistência à compressão dos corpos-de-prova confeccionados com essa cinza.

Pela técnica de Difratometria de raios $X$ pôde-se observar um halo presente no difratograma da CCCC in natura característico de materiais amorfos, como também vários picos de materiais cristalinos, com destaque para a Arcanita $\left(\mathrm{K}_{2} \mathrm{SO}_{4}-\right.$ sulfato de potássio).

Pelo ensaio de MEV, observou-se que as partículas da CCCC possuem aspecto lamelar, com camadas sobrepostas e pequenas partículas aderidas à superfície, formando grãos de tamanhos e formatos variados, de aproximadamente 10 a $75 \mu \mathrm{m}$.

Pelo ensaio de superfície específica pelo método BET constatou-se que mais de $30 \%$ da superfície específica das partículas de CCCC se referem aos poros internos. Essa característica pode explicar a maior demanda de água de amassamento e a perda de trabalhabilidade da argamassa quando há a substituição de cimento Portland (CPV ARI) por CCCC acima de $10 \%$.

\subsection{Análise da pozolanicidade}

A pozolanicidade da CCCC foi analisada com a cal e o cimento Portland, por meio de ensaios normativos. Porém os resultados obtidos não atingiram o mínimo exigido pelas respectivas normas, não sendo possível classificar a CCCC como material pozolânico. 
Os resultados da análise da resistência à compressão de argamassas confeccionadas com teores variados de CCCC em substituição ao cimento Portland, indicam que apenas o teor de 2,5\% apresentou valores estatisticamente iguais ao traço de referência. Os demais teores de CCCC promoveram a redução significativa dos valores da resistência à compressão das argamassas. O alto teor de ar incorporado observado em algumas amostras pode ter contribuído para os baixos valores de resistência à compressão observados nos corpos-de-prova de argamassa com teores de substituição acima de $10 \%$.

\subsection{Retração por secagem}

Os resultados das análises dos corpos-de-prova submetidos à retração por secagem indicam que o aumento do teor de CCCC foi proporcional aos valores de retração, até a idade de 56 dias. Os corpos-de-prova confeccionados com altos teores de CCCC (acima de $15 \%$ ) apresentaram elevado teor de ar incorporado, fato que pode ter sido determinante para os altos valores de retração por secagem das amostras analisadas.

\subsection{Profundidade de carbonatação}

Os resultados das análises de profundidade de carbonatação mostram que o uso de CCCC não retarda o processo de carbonatação em argamassas. Notou-se também que, para altos teores de substituição (acima de 20\%) a carbonatação ocorre inclusive no interior dos corpos-de-prova, principalmente devido ao alto teor de ar incorporado das argamassas confeccionadas com a CCCC. Entende-se que o teor de ar incorporado aferido ainda no estado fresco favoreceu o aparecimento de poros internamente conectados no estado endurecido, o que facilitou a difusão do $\mathrm{CO}_{2}$ até $\mathrm{o}$ interior dos corpos-de-prova confeccionados com teores de CCCC acima de $15 \%$.

\subsection{Estabilização/solidificação da CCCC}

Comparando-se os resultados da solubilização das pastas com os resultados obtidos com a CCCC in natura, observou-se a diminuição da concentração de vários elementos e substâncias químicas. Os parâmetros para Cádmio, Chumbo, Cloretos, Fenóis totais, Ferro total, Manganês, Nitratos e Prata ficaram abaixo do limite máximo exigido para o extrato solubilizado das pastas confeccionadas com teores variados de CCCC. Sendo assim, a 
matriz cimentícia apresentou-se como eficaz na diminuição ou anulação da concentração desses elementos e substâncias, segundo ensaio de solubilização (NBR 10006/04).

Para o Cromo total e o Sódio houve diminuição na concentração do extrato das pastas em relação ao da CCCC in natura, porém os valores ainda ficaram acima do limite máximo permitido no extrato solubilizado. Tem-se, portanto, que a matriz cimentícia não foi eficaz na estabilização/solidificação do Cromo e do Sódio, mas que essas substâncias também foram detectadas, em valores acima do limite máximo permitido, no extrato solubilizado da pasta confeccionada apenas com cimento Portland.

\subsection{Continuidade da pesquisa}

Para um melhor posicionamento quanto as considerações apontadas por esta pesquisa sobre a CCCC, são necessários ainda ensaios complementares que avaliem o grau de contaminação da CCCC quanto aos Pesticidas (Anexo F - NBR 10004). Tais resultados podem mudar os parâmetros para a classificação da CCCC como resíduo sólido.

Outros estudos que esta pesquisa também considera relevantes são listados a seguir:

o Avaliar mais profundamente a origem dos metais pesados e do Fenol na CCCC;

o Analisar a estabilização/solidificação da CCCC em argamassas e concretos, considerando variações no consumo de cimento e na relação a/c, o uso de adições minerais e aditivos, buscando condições que diminuam a mobilidade dos contaminantes no interior da matriz cimentícia;

- Estudar a retração por secagem em argamassas e concretos com CCCC em idades avançadas (acima de 119 dias);

o Estudar a origem da incorporação de ar em pastas e argamassas confeccionadas com CCCC;

o Estudar a influência da CCCC no tempo de trabalhabilidade e no tempo de pega em materiais cimentícios. 


\section{REFERÊNCIAS}

ADESANYA, D. A. (1996) Evaluation of blended cement mortar concrete and stabilization earth made from ordinary Portland cemente and corn cob ash. Construction and Building Materials, vol. $10, n^{\circ} 6$, pp. 451-456.

AGOSTINI-COSTA, T. S.; et al. (2000). Caracterização, por cromatografia em camada delgada, dos compostos fenólicos presentes em pedúnculos de caju (Anacardium ocidentale L.). B. CEPPA, Curitiba, v. 18, n. 1, p. 129137, Jan./Jun.

AGLODESTE. (2007). Aglomerados do nordeste Ltda. Disponível em: <http://www. reciclaveis.com.br/oport.htm>. Acesso em 25 fev. 2007.

AGROPOLOS. (2007). Castanhas de caju: exportações 2007. Disponível em: <http://www.agropolos.org.br/novidades2.php?id=0137\&tipo=2>. Acesso em 27 mar. 2008.

ALMEIDA, F. A. G.; FONTES, J. M.; ALMEIDA, F. C. G. (1988). Uso da cinza da casca de castanha de caju como fonte de fósforo para a cultura do sorgo. Revista de Ciência Agronômica. v. 19. p 67-72. Disponível em: <http://www.ccarevista.ufc.br/v19a1988 112rca19-1.pdf>. Acesso em 11 nov 2005.

ALMEIDA, F. A. G.; FONTES, J. M.; ALMEIDA, F. C. G. (1988). Uso da cinza da casca de castanha de caju como fonte de fósforo para a cultura do milho. Revista de Ciência Agronômica. v. 19. p 73-78. Disponível em: <http://www.ccarevista.ufc.br/v19a1988 113rca19-1.pdf>. Acesso em 11 nov 2005.

ALLOWAY, B. J. (1995). Cadmium. In: Heavy metals in soils. Glasgow: Blackie and Son, p.107-108.

ASOCIACIÓN MERCOSUR DE NORMALIZACIÓN (2000). NM 23 - Cimento Portland e outros materiais em pó - Determinação da densidade absoluta.

(2001). NM 49 - Agregado miúdo - determinação das impurezas orgânicas.

(2001). NM 53 - Agregado graúdo - determinação da massa específica, da massa específica aparente e da absorção de água.

ASSOCIAÇÃO BRASILEIRA DE MEDICINA COMPLEMENTAR - ABMC (2007). Agrotóxicos. Disponível em: <http://www.medicinacomplementar.com.br/Biblioteca_ de_Intoxicacoes. asp>. Acesso em: 21 Abr. 2007.

ASSOCIAÇÃO BRASILEIRA DE NORMAS TÉCNICAS - ABNT (1992). NBR 5739 Concreto - Ensaio de compressão de corpos-de-prova cilíndricos. Rio de Janeiro. 
(1992) NBR 5751 - Materiais pozolânicos - determinação da atividade pozolânica - índice de atividade pozolânica com cal. Rio de Janeiro.

(1992). NBR 5752 - Materiais pozolânicos - determinação da atividade pozolânica com cimento Portland - índice de atividade pozolânica com cimento. Rio de Janeiro.

(2003). NBR 7175 - Cal hidratada para argamassas - Requisitos. Rio de Janeiro.

(1982). NBR 7214 - Areia normal para ensaio de cimento - Especificação. Rio de Janeiro.

(1996). NBR 7215 - Cimento Portland - Determinação da resistência à compressão. Rio de Janeiro.

(1987). NBR 7218 - Agregado - determinação do teor de argila em torrões e materiais friáveis. Rio de Janeiro.

(1987). NBR 7219 - Agregado - determinação do teor de materiais pulverulentos. Rio de Janeiro.

(1994). NBR 7222 - Argamassa e concreto - Determinação da resistência à tração por compressão diametral de corpos-de-prova cilíndricos. Rio de Janeiro.

(1982). NBR 7251 - Agregado em estado solto: determinação da massa unitária. Rio de Janeiro.

(2004). NBR 10004 - Resíduos sólidos - Classificação. Rio de Janeiro, 2004.

(2004) NBR 10005 - Procedimento para obtenção de extrato lixiviado de resíduos sólidos. Rio de Janeiro.

(2004) NBR 10006 - Procedimento para obtenção de extrato solubilizado de resíduos sólidos. Rio de Janeiro.

(2004) NBR 10007 - Amostragem de resíduos sólidos. Rio de Janeiro.

(1991) NBR 11579 - Cimento Portland - Determinação da finura por meio da peneira 75 micrômetros (número 200). Rio de Janeiro.

(1992) NBR 12650 - Materiais Pozolânicos - determinação da variação da retração por secagem devido à utilização de materiais pozolânicos. Rio de Janeiro.

(1992) NBR 12653 - Materiais Pozolânicos. Rio de Janeiro. 
(1995) NBR 13278 - Argamassa para assentamento de paredes e revestimento de paredes e tetos - Determinação da densidade de massa e do teor de ar incorporado. Rio de Janeiro.

(1997) NBR 13956 - Sílica ativa para uso em cimento Portland, concreto, argamassa e pasta de cimento Portland - Especificação. Rio de Janeiro.

(1997) NBR 13957 - Sílica ativa para uso em cimento Portland, concreto, argamassa e pasta de cimento Portland - Método de ensaio. Rio de Janeiro.

(2006) Projeto 02:136.01-001/1. Edifícios habitacionais de até cinco pavimentos Desempenho Parte 1: Requisitos gerais. 15 Maio 2006.

ATIS, C. D. (2003) Accelerated carbonation and testing of concrete made with fly ash. Construction and Building Materials. V. 17, p.147-152.

ATIS, C. D. (2004) Carbonation-Porosity-Strength Model for Fly Ash Concrete (Technical Note). Journal of Materials in Civil Engineering. Jan-Fev 2004, p.91-94.

BASÍLIO, F. A. (1984) MgO no cimento Portland. In: Seminário sobre Durabilidade do Concreto. Reunião Anual de 1984, Instituto Brasileiro do Concreto - IBRACON. Anais... São Paulo, SP.

BOLETIM QUANTUM (2003) Boletim educativo do Núcleo de Comunicação do Centro Tecnológico da UFSC. Ano 2, n.1, Ago. Disponível em: <http://www.ctc.ufsc.br/Nucleo/ quantum.htm>. Acesso em 22 mar. 2006.

BYFORS, K. (1985). Carbonation of concrete with silica fume and fly ash. Nordic Concrete Research, no. 4, pp. 26-35.

CAMELO, D.; et al. (2005). Contribuição ao estudo de aproveitamento da cinza da casca da castanha-do-pará como material pozolânico. In: $47^{\circ}$ Congresso Brasileiro do Concreto IBRACON. Anais... Olinda, Brasil : IBRACON. CD-ROM.

CAPOBIANCO, J P. (2007). Chave para o século XXI: Caju e Câncer. Disponível em: <http://www.mre.gov.br/cdbrasil/itamaraty/web/port/meioamb/biodiv/divbio/index.htm>.

Acesso em 25 fev. 2007.

CARIOCA, J. O. B.; et al. (2005). Processo de purificação do liquido da castanha do caju (LCC) para isolamento do cardanol. $3^{\circ}$ Congresso Brasileiro de P\&D em Petróleo e Gás. Anais... Salvador, Bahia. Disponível em: <http://www.portalabpg.org.br/PDPetro/3/trabalhos /IBP0670_05.pdf>.

CHANDRA, S. (1996). Waste materials used in concrete manufacturing / edited by Satish Chandra. Building Materials Science Series. Noyes Publications : New Jersey. 
CHERIAF, M.; ROCHA, J. C. (1997). Caracterização dos Resíduos Industriaiss do Estado de Santa Catarina e as Possibilidades de Valorização na Construção Civil In: ENCONTRO NACIONAL SOBRE EDIFICAÇÕES E COMUNIDADES SUSTENTÁVEIS, Anais... p. 81-86.

CINCOTTO, M. A. (1988). Utilização de subprodutos e resíduos na indústria da construção civil. In: Tecnologia de Edificações. São Paulo, Pini/ IPT, p.71-74.

CINCOTTO, M. A. (2007). Materiais pozolânicos. Nota de aula da disciplina "Aglomerantes de argamassas e concretos". PCC/EPUSP.

CINCOTTO, M.A.; KAUPATEZ, R.Z. (1988). Seleção de materiais quanto à atividade pozolânica. In: Tecnologia de Edificações. São Paulo, Pini/ IPT, p.23-26.

CINCOTTO, M. A.; et al. (1990). Optimizaton of rice husk ash production. In: INTERNATIONAL SIMPOSYUM ON VEGETABLES PLANTS AND THEIR FIBRES AS BUILDING MATERIALS, 2. Salvador. Proceedings... London : Chapman and Hall, 1990. p. 334-342.

CIB. (2000). Agenda 21 para a construção sustentável. Tradução: I. Gonçalves e T. Whitaker. São Paulo. G. Weinstock, D. M. Weinstock. EP/ USP. 131p.

CONAB. (2006). Avaliação da Safra Agrícola de cana-de-açúcar 2006/2007, Terceiro Levantamento, nov/2006. Disponível em: <http://www.conab.gov.br/conabweb/download/ safra/BoletimCanaNovembro2006-07.pdf>. Acesso em 07 Out. 2007.

CONAB. (2007). Castanha de Caju. Disponível em: < http://www.conab.gov.br/conabweb/ download/sureg/ce/conjunturacastanhadecaju.pdf>. Acesso em 27 Mar. 2008.

CONNER, J. R. (1990). Chemical fixation and solidification of hazardous wastes. Van Nostrand Reinhold, New York..

CORDEIRO, G. C.; et al. (2005). Avaliação da reatividade da cinza residual do bagaço de cana de açúcar com cimento portland e cal. In: $47^{\circ}$ Congresso Brasileiro do Concreto IBRACON. Anais... Olinda, Brasil : IBRACON. CD-ROM.

CORDEIRO, G. C. (2006). Utilização de cinzas ultrafinas do bagaço de cana-de-açúcar e da casca de arroz como aditivos minerais em concreto. Tese de Doutorado, Universidade Federal do Rio de Janeiro, COPPE/UFRJ.

CULLINANE Jr, M. J.; et al. (1986). Handbook for Stabilization/Solidification of hazardous wastes. Environmental Protection Agency, Cincinnati, Ohio.

CYR, M.; LAWRENCE, P.; RINGOT E. (2006). Efficiency of mineral admixtures in mortars: Quantification of the physical and chemical effects of fine admixtures in relation with compressive strength. Cement and Concrete Research. v. 36, p.264-277. 
DA FONSECA, M. G. (1993). Tijolos de cinzas - Cinza de carvão mineral e cinza de casca de arroz - alternativas ecológicas na fabricação de novos elementos construtivos para alvenarias. In: Encontro de Tecnologia no Ambiente Construído, São Paulo. Anais... / coord. A. K. Abiko, V. M. John. São Paulo. São Paulo : EPUSPIANTAC (CD-ROM).

DAL MOLIN, D. C. C. (2005). Adições minerais para concreto. In: Concreto : ensino, pesquisas e realizações / editor Geraldo Cechella Isaia. São Paulo : IBRACON, 2v.

DANIALI, S. (1990). Solidification/Stabilization of heavy metals in latex modified Portland cement matrices. Journal of Hazardous Materials, $n^{\circ} 24$, p. 225-230.

DI CAMPOS, M. S. (2005). Aproveitamento das cinzas da queima da cama sobreposta de suínos como substituição parcial do cimento Portland. Pirassununga, 2005. $121 \mathrm{f}$. Dissertação (Mestrado) - FZEA/USP.

DICIONÁRIO AURÉLIO. (2005). Novo Dicionário Eletrônico Aurélio versão 5.0. $3^{\mathrm{a}}$. Edição. Edição eletrônica Positivo Informática Ltda. Positivo.

ELINWA, A. U.; MAHMOOD, Y. A. (2004). Ash from timber waste as cement replacement material. Cement and Concrete Composites. v. 24, p. 219-222.

EMBRAPA. (2006). Sistemas de Produção, n. 1. ISSN 1678-8702 Versão eletrônica. Disponível em: <http://sistemasdeproducao.cnptia.embrapa.br/Fontes HTML/Caju/Cultivodo Cajueiro/index.htm\#topo>. Acesso em 06 abr. 2006.

FREITAS, E. G. A. (1996). Obtenção de tijolos de solo-cimento com adição de cinzas de bagaço de cana para uso em construção civil. 196f. Dissertação (Mestrado em Engenharia Civil) - Universidade Federal Fluminense, Rio de Janeiro.

GERVEN, T. V. et al. (2007). Effects of carbonation and leaching on porosity in cementbound waste. Waste Management, vol 27, p. 977-985.

GEYER, A; et al. (1993). Sistema construtivo para habitação popular utilizando resíduos agrícolas. In: Encontro de Tecnologia no Ambiente Construído, São Paulo. Anais... / coord. A. K. Abiko, V. M. John. São Paulo. São Paulo : EPUSPIANTAC. (CD-ROM).

GREENPEACE. (1992). Convenção das Nações Unidas sobre Mudanças Climáticas. Disponível em: <http://www.greenpeace.org.br/clima/pdf/convencao_onu.pdf>. Acesso em 12 fev. 07.

HEBATPURIA, V. M. et al. (1999). Immobilization of phenol in cement-based solidified/stabilized hazardous wastes using regenerated activated carbon: leaching studies. Journal of Hazardous Materials, $n^{\circ}$ B70, p. 117-138.

HERNÁNDEZ, J. F. M.; et al. (1998). Use of wastes of the sugar industry as pozzolana in lime-pozzolana binders: study of the reactions. Cement and Concrete Research. V. 28, p. $1525-1536$. 
HO, D. W. S.; LEWIS, R. K. (1983). Carbonation of concrete incorporating fly ash or a chemical admixture. First International Conference on the use of Fly Ash, Silica Fume, Slag and other Mineral By-Products in Concrete. Proceedings... Montebello, Canada. pp. 333346.

IBGE (2006). Levantamento sistemático da produção agrícola. Disponível em: http://www.ibge.net/home/estatistica. Acesso em: 12 Out. 2006.

JOHN, V. M. (2000). Reciclagem de resíduos na construção civil. Contribuição á metodologia de pesquisa e desenvolvimento. 113 p. São Paulo, 2000. Tese (LivreDocência). Escola Politécnica, Universidade de São Paulo.

JOHN, V. M.; et al. (2003). Cinzas e aglomerantes alternativos. In: Tecnologias e materiais alternativos de construção / W. J. Freire, A. L. Beraldo (coord.) - Campinas, SP : Editora da UNICAMP, 2003. p. 145-190.

JOHN, V. M.; ÂNGULO, S. C. (2003). Metodologia para desenvolvimento de reciclagem de resíduos. In: Utilização de Resíduos na Construção Habitacional / Editores J. C. Rocha [e] V. M. John. - Porto Alegre: ANTAC. - (Coleção Habitare, v.4).

KAHN, H. (2007). Microscopia eletrônica de varredura e microanálise química. Nota de aula da disciplina "Aglomerantes de argamassas e concretos". PCC/EPUSP, 2007.

LAWRENCE, P.; CYR, M.; RINGOT E. (2005). Mineral admixtures en mortars: effect of type, amount and fineness of fine constituents on compressive strength. Cement and Concrete Research. V. 35, p.1092-1105.

LEA, F. M. (1938). The chemistry of pozzolans. In: Simposium on the chemistry of cement.

LIMA, S. A. (2003). Produção de telhas com embalagem longa vida. 1 Fotografia, color., $10 \mathrm{~cm} \times 15 \mathrm{~cm}$.

LIMA, S. A.; et al. (2004). Análise da viabilidade técnica do resíduo da castanha do caju em tijolos do adobe. In: IV Encontro de Iniciação Científica e Tecnológica - ENICIT. Fortaleza CE. Anais..., p. 49.

LOPES NETO, A. (1997). Agroindústria do caju. Fortaleza: IPLANCE, 263 p.

LOTHIA, R. P.; JOSHI, R. C.; (1995). Mineral Admixtures. In: RAMACHANDRAN, V. S. (ed.) Concrete admixtures handbook - properties, science, and technology. Building Materials Science Series. $2^{a}$. edição. ISBN 0-8155-1373-9, p. 657-739.

MALHOTRA, V. M; MEHTA, P. K. (1996). Pozzolanic and cementitious materials. (Advances in Concrete Technology, vol. 1.

MANNAN, M. A.; GANAPATHY, C. (2004). Concrete from an agricultural waste oil-palm shell (OPS). Building \& Environment. Vol. 39, p. 441-448. 
MAPA - Ministério da Agricultura, Pecuária e Abastecimento. (2007). Evolução da Produtividade da cana-de-açúcar no Brasil. Disponível em: <http://www.agricultura. gov.br>. Acesso em: 2 Abr. 2007.

MASCARENHAS, H. A. A.; et al. (1994). Efeito de adubos potássicos na produção de soja. Scientia Agrícola. Vol. 51, $n^{\circ}$.1, Piracicaba Jan./Apr.

MEHTA, P. K. (1992). Rice husk ash - A unique supplementary cementing material. In V. M. Malhotra (ed.) Advances in concrete technology. $2^{a}$. edição. Ottawa : CANMET, p. 407431.

MEHTA, P. K. (1999). Concrete Technology for sustainable development. Concrete International. V. 21, n. 11, p 47-53.

MEHTA, P. K.; MONTEIRO, P. J. M. (1994). Concreto - estrutura, propriedades, materiais. São Paulo : PINI, p. 290-309.

MELO NETO, A. A. (2002). Estudo da retração em argamassa com cimento de escória ativada / Antônio Acácio de Melo Neto. São Paulo. 161 p. Dissertação (Mestrado) - EPUSP. Departamento de Construção Civil e Urbana.

MERRIT, S. D.; et al. (1993). Applications of soil and cement chemistry to stabilization/ solidification. Transportation Research Record, $n^{\circ} 1424$.

MONTGOMERY, D. C.; RUNGER, C. R. (2003). Estatística aplicada e probabilidade para engenheiros / D. C. Montgomery and G. C. Runger; traduzido por Verônica Calado. Rio de Janeiro : LTC Editora, 2a . Edição. 463 p.

NEVILLE, A. M. (1992). Concrete in the year 2000. In V. M. Malhotra (ed.) Advances in concrete technology. $2^{a}$. edição. Ottawa : CANMET, p. 21-78.

NEVILLE, A. M. (1997). Propriedades do concreto. São Paulo : PINI.

NEFUSSI, N. (1985). Gerenciamento de resíduos. In: I Encontro sobre Resíduos Sólidos Industriais, Porto Alegre, 1985. Anais... Porto Alegre, p. 33-54.

NEHDI, M.; et al. (2003). Performance of rice husk ash produced using a new technology as a mineral admixture in concrete. Cement and Concrete Research. v. 33, p. 1203-1210.

NOLASCO, A. M. (1993). Utilização de resíduo da indústria de papel na produção de materiais para a construção civil. São Carlos. 140f + anexos. Dissertação (Mestrado em Arquitetura) - Escola de Engenharia de São Carlos.

NOLASCO, A. M; AGNESINI, M. V. (1993). Utilização de resíduo da indústria de papel na produção de materiais para a construção civil. In: Encontro de Tecnologia no Ambiente Construído, São Paulo. Anais... A. K. Abiko, V. M. John (coord.). São Paulo : ANTAC. 
ODA, G. A.; LIBÓRIO, J. B. L. (2002). Estudo da adição da sílica ativa da casca do arroz em matrizes de cimentos Portland. In: V Simpósio em Ciência e Engenharia de Materiais, São Carlos, 2002. Resumos. São Carlos : CETEPE.

ODLER, I. (2003). The BET-specific surface area of hydrated Portland cement and related materials. Cement and Concrete Research. v. 33, p. 2049-2056.

PABLOS, J. M.; SICHIERI, E. P. (2007). Estudo para a reciclagem do resíduo sólido gerado pelas areias de fundição aglomeradas com argila, através da solidificação/estabilização em matrizes de cimento Portland, para a aplicação no setor da construção civil. In: Reciclagem de resíduos para a construção civil, FUMEC/ FEA/ Eduardo Chahud (org.), Belo Horizonte : FUMEC, p. 133-167.

PAIVA, F. F. A.; et al. (2000). Aproveitamento industrial do caju. EMBRAPA/ SEBRAECE, 83p.

PASSOS, J. A. L.; NEDER, L. T. C. (2000). Encapsulamento: uma técnica moderna de processamento de resíduos sólidos perigosos. In: XXVII Congresso Interamericano de Engenharia Sanitária e Ambiental, 2000, Fortaleza. Anais ..., v. III.

PEKMEZCI, B. Y.; AKYÜZ, S. (2004). Optimum usage of a natural pozzolan for the maximum compressive strength of concrete. Cement and Concrete Research. v. 34, p. 2175-2179.

PELINO, M. (2000). Recycling of zinc-hydrometallurgy wastes in glass and glass-ceramic materials. Waste Management, Amsterdam, v.20, p.561-568.

PETINARI, R. A.; TARSITANO, M. A. A. (2002). Comercialização de caju in natura na região noroeste do estado de São Paulo. Revista Brasileira de Fruticultura. v. $24 \mathrm{n}^{\circ} 3$. Jaboticabal, SP.

PETRUCCI, E. G. R. (1995). Materiais de construção / Eládio G. R. Petrucci. - 10. ed. São Paulo : Globo, p. 342-344.

PINTO, T. P. (1999). Metodologia para a gestão diferenciada de resíduos sólidos da construção urbana. São Paulo, Escola Politécnica, Universidade de São Paulo. Tese (Doutorado). 189p.

PORTAL DE INVESTIMENTOS DO ESTADO DE SÃO PAULO. (2006). Agronegócios. Disponivel em: <http://www.investimentos.sp.gov.br/setores/agronegocios.htm>. Acesso em 05 abr. 2006.

PRUDÊNCIO Jr, L. R.; et al. (2003). Cinza da casca de arroz. In: Utilização de Resíduos na Construção Habitacional, Coleção Habitare, v.4, Porto Alegre: ANTAC. 
PRUDÊNCIO Jr., L. R.; SANTOS, S. (1997). Influência do grau de moagem na pozolanicidade da cinza da casca de arroz. In: Workshop sobre Reciclagem e Reutilização de Resíduos como Material de Construção Civil. - V. M. John, J. R. Cavalcante (coord) Anais... São Paulo : EPUSPIANTAC.

RAMALHO, J. F. G. P.; SOBRINHO, N. M. B. A. (2001). Metais pesados em solos cultivados com cana-de-açúcar pelo uso de resíduos agroindustriais. Floresta e Meio Ambiente. v. 8, n.1, p.120 - 129, jan./dez.

REDDI, L. N. et al. (1996). Stabilization of phenolics in foundry cementitious materials. Journal of Hazardous Materials, $n^{\circ} 45$, p. 89-106.

RÊGO, J. H. S.; et al. (2004). Estudo de aglomerantes compostos por cimento portland comum (CPI) e as cinzas de casca de arroz (CCA) amorfa e cristalina. In: $46^{\circ}$ Congresso Brasileiro do Concreto - IBRACON. Anais... Florianópolis, Brasil : IBRACON. CD-ROM.

RICHARDSON, M.G. (1988). Carbonation of reinforced concrete: Its causes and management. New York: CITIS Ltd, Publishers.

ROCHA, J. C.; CHERIAF, M. (2003). Aproveitamento de resíduos na construção. In: Utilização de Resíduos na Construção Habitacional, Coleção Habitare, v.4, Porto Alegre: ANTAC.

ROSA, G. R. (2005). Anuário Brasileiro de Arroz 2005. Santa Cruz do Sul : Ed. Gazeta Santa Cruz, 136p.

SANTOS, E. (2004). Tecnologia aproveita bagaço do caju. Disponível em: <http://www.embrapa.br/noticias/banco_de_noticias/2000/abril/bn.2004-1125.7936327939/ mostra_noticia>. Acesso em 25 fev. 2007.

SANTOS, R. P.; et al. (2007). Production and characterization of the cashew (Anacardium occidentale L.) peduncle bagasse ashes. Journal of Food Engineering. v. 79, p. 14321437.

SANTOS, S. (1997). Estudo da viabilidade de utilização de cinza da casca de arroz residual em argamassas e concretos. 113f. Dissertação (Mestrado em Engenharia) Universidade Federal de Santa Catarina, Florianópolis.

SANTOS, S.; PRUDÊNCIO Jr, L. R. (1998). Estudo comparativo da pozolanicidade de cinza volante e cinza de casca de arroz residual. In: VII Encontro de Tecnologia no Ambiente Construído - ENTAC. Florianópolis-SC. Anais... Florianópolis : ANTAC (CD-ROM).

SECITECE. (2007). Pesquisa do uso de derivado do caju em combustíveis. Disponível em: <http://www.sct.ce.gov.br/seciteceHistórico.asp>. Acesso em 15 fev. 2007. 
SEMINÁRIO CIDADES, CIÊNCIA E TECNOLOGIA. (2003) Cooperação Brasil - França: anais. / Org. Maria Lúcia Horta de Almeida, Patricia Morgantti, Roberto Lamberts. - Porto Alegre : ANTAC.

SILVA, A. C.; et al. (2005). Utilização do Resíduo da Castanha do Caju na Confecção de Tijolos de Terra Crua (adobe): Alternativas para Redução do Custo Final de Moradias de Interesse Social no Brasil. In: X Encontro de Geógrafos da América Latina - EGAL. Anais... São Paulo - SP.

SILVA, F. G. (2006). Estudo de concretos de alto desempenho frente à ação de cloretos. Tese (Doutorado). Interunidades em Ciência e Engenharia de Materiais. EESC/IFSC/IQSC. São Carlos, SP.

SILVA, F. G. S.; et al. (2005). Influência dos efeitos pozolânico e microfiller na resistência à compressão do concreto. In: $47^{\circ}$ Congresso Brasileiro do Concreto - IBRACON. Anais... Olinda, Brasil : IBRACON. CD-ROM.

SILVA, M. G; et al. (1993). Proposta para reaproveitamento de resíduos industriais da região da grande Vitória em componentes para construção civil. In: Encontro de Tecnologia no Ambiente Construído, São Paulo, Anais... / A. K. Abiko, V. M. John (coord.). São Paulo : ANTAC.

SILVA, M. G; SOUZA, F. L. S. (1995). Proposta de utilização de resíduos da indústria de celulose e papel e entulho de obra em componentes de construção. In: VI Encontro de Tecnologia no Ambiente Construído, Rio de Janeiro, Anais... Rio de Janeiro : ANTAC.

SILVA, M. G; SOUZA, F. L. S.; SILVA, V. G. (1996). Reciclagem de cinza de casca de eucalipto e entulho de obra em componentes da construção. In: Workshop sobre reciclagem e reutilização de resíduos como material de construção civil, São Paulo, Anais / Coord. V. M. John [e] J. R. Cavalcante - São Paulo : EPUSP/ANTAC, 184p.

SILVA, V. M. (2007). Ação da carbonatação em vigas de concreto armado em serviço, construídas em escala natural e reduzida / V. M. Silva. São Carlos. Tese (Doutorado) Escola de Engenharia de São Carlos, Universidade de São Paulo.

SINGH, N. B.; SINGH, V. D.; RAI, S. (2000). Hydration of bagasse ash-blended Portland cement. Cement and Concrete Research, v. 30, pp. 1485-1488.

SOUZA G. N.; et al. (2007). Desenvolvimento de argamassas com substituição parcial do cimento Portland por cinzas residuais do bagaço de cana-de-açúcar. In: 49o Congresso Brasileiro do Concreto, Bento Gonçalves, RS. Anais do 49o. CBC. São Paulo, SP: IBRACON.

SOUZA, M. F.; LIBÓRIO, J. B. L.; BATISTA, P. S. (1999). Processo de extração da sílica contida na casca e na planta do arroz. Patente: Privilégio de Inovação. n. PI9903208. 30 jun. 1999 (Depósito), São Carlos.

TAY, J. H.; SHOW, K. Y. (1996). Utilization of ashes from oil-palm wastes as cement replacement material. Water and Science Technology, vol. 34, n¹1, p. 185-192. 
TEO, D. C. L. ; MANNAN, M. A.; KURIAN, V. J. (2006). Structural concrete using oil palm shell (OPS) as lightweight aggregate. Turkish Journal of Engineering and Environmental Science. Vol. 30, pp. 251 - 257.

TREZZA, M. A.; SCIAN, A. N. (2007). Waste with chrome in the Portland cement clinker production. Journal of Hazardous Materials, $n^{\circ} 147$, p. 188-196.

UDOEYO, F.F., DASHIBIL, P.U. (2002). Sawdust ash as concrete material. Journal of Materials in Civil Engineering. March/April, p. 173-176.

UDOEYO, F. F.; et al. (2006). Potential of wood waste ash as an additive in concrete. Journal of Materials in Civil Engineering. July/ August, p. 605-611.

VAN VLACK, L. H. (1970). Princípios de ciência dos materiais / Lawrence H. Van Vlack; traduzido por Luiz Paulo Camargo Ferrão. São Paulo : Editora Edgard Blücher Ltda, 427 p.

VIPULANANDAN, C.; KRISHNAN, S. (1990). Solidification/stabilization of phenolic waste with cementitious and polymeric materials. Journal of Hazardous Materials, $n^{\circ} 24, p .123-$ 136.

WORLD RICE PRODUCTION. (2006). Quarterly international Trade Report, Disponível em: <www.fas.usda.gov>. Acesso em 15. mar. 2006.

YIN, C. Y.; et al. (2008). Oil palm ash as partial replacement of cement for solidification/stabilization of nickel hydroxide sludge. Journal of Hazardous Materials, $\mathrm{n}^{\circ}$ 150 p. 413-418.

ZARDO, A. M.; et al. (2005). Aproveitamento de cinzas da queima de resíduos agroindustriais na produção de compósitos para construções. In: $13^{\circ}$ Simpósio Internacional de Iniciação Científica - SIIC. Anais... FZEA /USP. CD-ROM.

ZHANG, J.; BISHOP, P. L. (2002). Stabilization/solidification (S/S) of mercury-containing wastes using reactivated carbon and Portland cement. Journal of Hazardous Materials, $\mathrm{n}^{\circ}$ B92, p. 199-212.

ZHANG, M. H.; LASTRA, R.; MALHOTRA, V. M. (1996). Rice-husk ash paste and concrete: some aspects of hydration and microestructure of the interfacial zone between the aggregate and the paste. Cement and Concrete Research. v. 26, p. 963-977. 


\section{GLOSSÁRIO}

Adições minerais. Materiais siliciosos ou silicaluminosos finamente moídos, adicionados ao concreto em quantidades relativamente grandes, na proporção de 20 a $100 \%$ da massa de cimento Portland, em adição ou substituição ${ }^{33}$.

Alumina. (Quím.) O trióxido de dialumínio. [fórm.: $\mathrm{Al}_{2} \mathrm{O}_{3}$ ].

Amorfo. (Fís.-Quím.) Diz-se de um estado de agregação inteiramente isotrópico. (Min.) Dizse de mineral que não apresenta estrutura cristalina.

Brucita. (Min.) Mineral trigonal, hidróxido de magnésio.

Carcinoma. (Patol.) Tumor maligno constituído por células epiteliais, com tendência a invadir as estruturas próximas e a produzir metástase.

Cardol. Popularmente conhecido como LCC (líquido da castanha do caju), extraído da castanha por pirólise (queima) ou prensagem, é utilizado na produção de solventes, vermífugas, e como combustível em caldeiras.

Cajueiro. (Bot. Bras.) Árvore da família das anacardiáceas (Anacardium occidentale), de folhas grandes, flores minutas, muito cultivada para obtenção do fruto, chamado vulgarmente castanha, uma noz que contém um óleo muito cáustico e uma amêndoa que, torrada, é apreciadíssima por seu sabor. A parte comestível, erroneamente considerada como fruto, é o caju, com o qual se preparam doces e bebidas.

CH. Fórmula abreviada do hidróxido de cálcio.

Cimento. Substância em pó, utilizada como aglomerante ou para ligar certos materiais, e que, umedecida, se usa em estado plástico, endurecendo, depois, pela perda da água.

Cimento Portland. Cimento comumente usado em concretos e argamassas em geral, obtido pela pulverização de uma mistura de materiais calcários e argilosos, a qual se calcina até a fusão incipiente.

CIONE. Companhia Industrial de Óleos do Nordeste.

CP. Abreviatura de corpos-de-prova.

${ }^{33}$ MEHTA, P. K.; MONTEIRO, P. J. M. (1994). Concreto - estrutura, propriedades, materiais. São Paulo : PINI, p. 290-309. 
C-S-H. Fórmula abreviada do silicato de cálcio hidratado.

Dermatite Eczematosa (Eczema). (Derm.) Dermatose inflamatória caracterizada pela formação de vesículas confluentes, causando prurido, provocada por diferentes causas.

Decorticação. Ato de decorticar.

Decorticar. Tirar o córtice, a cortiça, a casca a; descascar, descortiçar; descortiçar.

Encapsulamento. Ação ou processo de encapsular.

Fíler. (filler) adição mineral finamente dividida sem atividade química, cuja ação se resume ao efeito físico de empacotamento granulométrico e ação como pontos de nucleação para a hidratação dos grãos do cimento.

FINEP. Financiadora de Estudos e Projetos.

IPT. Instituto de Pesquisas Tecnológicas

LCC. Nome popular do líquido da castanha do caju; cardol.

Magnésia. (Quím.) O óxido de magnésio, branco, cristalino. [fórm.: MgO].

Material pozolânico. Material silicioso ou silicaluminoso que, por si sós, possuem pouca ou nenhuma atividade aglomerante, mas que, quando finamente divididos e na presença da água, reagem com o hidróxido de cálcio à temperatura ambiente para formar compostos com propriedades aglomerantes ${ }^{34}$.

Material cimentante. Material que não necessita do $\mathrm{CH}$ presente no cimento para formar $\mathrm{C}$ S-H. No entanto sua auto-hidratação é normalmente lenta e os produtos cimentantes formados são insuficientes para utilização do material com fins estruturais.

Nicho. (Market.) Segmento restrito do mercado, não atendido pelas ações tradicionais de marketing, e que geralmente oferece novas oportunidades de negócio.

PADETEC. Parque de Desenvolvimento Tecnológico.

Periclásio. (Min.) Mineral monométrico, óxido de magnésio; periclasita.

Petrografia. Estudo descritivo e sistemático das rochas.

\footnotetext{
${ }^{34}$ NBR $12653 / 92$.
} 
Petrográfico. Relativo à petrografia.

pH. (Quím.) Sigla de potencial hidrogeniônico.

Pozolana. Produto de origem piroclástica (originários das atividades vulcânicas explosivas), que se encontra nas imediações de Pozzuoli (Itália), e que, misturado com cal, se usa como cimento hidráulico.

Pozolânico. Referente à pozolana, ou da natureza dela.

Pseudofruto. (Bot.) Órgão semelhante a uma baga (Fruto carnoso, indeiscente), resultante do crescimento de partes acessórias da flor, como, por exemplo, o pedicelo dos cajueiros; pode incluir ou não a semente.

Raios X. (Fís.) Radiação eletromagnética de comprimento de onda compreendido, aproximadamente, entre $10^{-11}$ e $10^{-8} \mathrm{~cm}$.

Reciclagem. Prática ou técnica na qual os resíduos podem ser usados com a necessidade de tratamento para alterar as suas características físico-químicas ${ }^{35}$.

Resíduo. O que sofreu alteração de qualquer agente exterior, por processos mecânicos, químicos, físicos, etc.

Resíduos sólidos. Resíduos nos estados sólido e semi-sólido, que resultam de atividades de origem industrial, doméstica, hospitalar, comercial, agrícola, de serviços e de varrição. Ficam incluídos nesta definição os lodos provenientes de sistemas de tratamento de água, aqueles gerados em equipamentos e instalações de controle de poluição, bem como determinados líquidos cujas particularidades tornem inviável o seu lançamento na rede pública de esgotos ou corpos de água, ou exijam para isso soluções técnica e economicamente inviáveis, em face à melhor tecnologia disponível.

Reutilização. (Tec.) Procedimento em que material que já fora anteriormente processado se insere, após o tratamento conveniente, numa corrente do mesmo, ou de outro processo.

Rubefaciente. (Terap.) Medicamento que produz rubefação.

Rubefação. (Méd.) Vermelhidão da pele, provocada por inflamação.

Sílica. (Quím.) Dióxido de silício, cristalino, abundantíssimo na crosta terrestre.

\footnotetext{
${ }^{35}$ LEI ESTADUAL № 12.300, de 16 de Março de 2006 - Institui a Política Estadual de Resíduos Sólidos e define princípios e diretrizes, p. 5.
} 
Silício. (Quím.) Elemento de número atômico 14, não metálico, cinzento, leve, duro, muito abundante na crosta terrestre, semicondutor largamente utilizado em eletrônica de estado sólido.

Siliciosa. Que contém sílica; que é da mesma natureza do sílex.

Silicaluminoso. Composto de sílica e alumínio.

Snacks. (Inglês) Salgadinhos, petiscos; refeição ligeira.

Subproduto. Produto que se retira do que resta de uma substância da qual se extraiu o produto principal. Exemplo: "os subprodutos do petróleo".

Vesicante. (Patol.) Que ou aquilo que produz vesícula(s).

Vesículas. (Derm.) Pequena bolha cutânea que contém líquido seroso.

Vítreo. Diz-se da textura da rocha ou da massa fundamental que não tem elementos cristalinos. 


\section{APÊNDICE A}

\section{INFERÊNCIA ESTATÍSTICA}

\section{A.1. ESCOLHA E JUSTIFICATIVA DO MÉTODO}

Emprega-se a distribuição t de "Student" para realizar inferência estatística entre uma amostra pequena $(\mathrm{n}<30)$ - de média $\bar{X}$ e desvio-padrão $s$ - pertencente a uma dada população - média $\mu$ e desvio-padrão $\sigma$ - isto é, se $\bar{X}=\mu$. Utiliza-se também para testar se duas amostras pequenas (média $\bar{X}_{1}$ e $\bar{X}_{2}$ ), pertencem a uma mesma população, ou seja, se $\mu_{1}=\mu_{2}$.

Para esta pesquisa, utilizou-se de tal ferramenta para analisar a hipótese de igualdade entre as médias das resistências das amostras dos Grupos A e B e a média do traço padrão, denominado TR0, ou seja, se são estatisticamente iguais.

a) Definição de hipóteses: a hipótese nula $\left(\mathrm{H}_{0}\right)$ representa a possibilidade de se afirmar se $\bar{X}=\mu$ (comparação de amostra com população) ou se $\mu_{1}=\mu_{2}$ (comparação entre duas amostras). A rejeição da hipótese nula (chamada de hipótese alternativa, $\mathrm{H}_{1}$ ) representa que não há indícios suficientes para afirmar que $\mathrm{H}_{0}$ é verdadeiro para um nível de significância a (exemplo: intervalo de confiança de 95\% representa um nível de significância de 1-0,95 =0,05).

b) Estatística de teste (comparação de amostra com população): O intervalo de confiança é representado entre os valores críticos - $t_{0,025}$ e $t_{0,025}$ (para o intervalo de confiança de 95\%, tabelado, e distribuição bilateral). A estatística de teste "t" é apresentada abaixo:

$$
\mathrm{t}=\frac{\overline{\mathrm{x}}-\mu}{\mathrm{s}} \sqrt{\mathrm{n}-1}
$$

em que: $\mathrm{n}=$ tamanho da amostra, e $\mathrm{n}-1$ = número de graus de liberdade $(v)$. 
Portanto, a estatística de teste "t" deve estar dentro do intervalo, conforme apresentado abaixo, para que a hipótese nula $\mathrm{H}_{0}$ possa ser aceita.

$$
-t_{0,025} \leq \frac{\bar{x}-\mu}{s} \sqrt{n-1} \leq t_{0,025}
$$

No caso da distribuição ser considerada unilateral, com nível de significância 0,05 , o "t" crítico é determinado como $t_{0,95}$. Neste caso, as condições para que a hipótese nula seja rejeitada é de que $t>t_{0,05}$ ou $t<t_{0,05}$.

c) Estatística de teste (comparação entre duas amostras - variâncias desconhecidas, porém iguais): O intervalo de confiança é representado entre os valores críticos $-t_{0,025}$ e $t_{0,025}$ (para o intervalo de confiança de 95\%, tabelado, e distribuição bilateral), e grau de liberdade $(v)=n_{1}+n_{2}-2$.

A estatística de teste "t" é apresentada na Equação A3.

$$
\mathrm{t}=\frac{\overline{\mathrm{X}}_{1}-\overline{\mathrm{X}}_{2}}{\sigma \sqrt{\frac{1}{\mathrm{n}_{1}+1 / \mathrm{n}_{2}}}}
$$

Em que: $\mathrm{n}_{1}=$ tamanho da amostra $1 ; \mathrm{n}_{2}=$ tamanho da amostra 2; $\sigma=$ desvio-padrão das duas populações (devem ser iguais).

O desvio-padrão deve ser definido como na Equação A4.

$$
\sigma=\sqrt{\frac{n_{1} s_{1}^{2}+n_{2} s_{2}^{2}}{n_{1}+n_{2}-2}}
$$

Em que: $s_{1}=$ desvio-padrão da amostra 1; e $s_{2}=$ desvio-padrão da amostra 2.

Da mesma forma que no caso anterior, a estatística de teste "t" deve estar dentro do intervalo, conforme Equação A5, para que a hipótese nula $\mathrm{H}_{0}$ possa ser aceita.

$$
-\mathrm{t}_{0,025} \leq \frac{\overline{\mathrm{X}}_{1}-\overline{\mathrm{X}}_{2}}{\sigma \sqrt{\frac{1 / \mathrm{n}_{1}}{}+\sqrt{1 / \mathrm{n}_{2}}}} \leq \mathrm{t}_{0,025}
$$


No caso da distribuição ser considerada unilateral, com nível de significância 0,05, o "t" crítico é determinado como $t_{0,05}$. Neste caso, as condições para que a hipótese nula seja rejeitada é de que $t>t_{0,05}$ ou $t<t_{0,05}$.

d) Estatística de teste (comparação entre duas amostras - variâncias desconhecidas e diferentes):

Neste caso, todas as premissas expostas no item anterior são válidas, exceto a formulação da estatística de teste "t", agora chamada de "t*" (Equação A6) e o número de grau de liberdade (v) (Equação A7).

$$
\begin{aligned}
& \mathrm{t}^{*}=\frac{\overline{\mathrm{X}}_{1}-\overline{\mathrm{X}}_{2}}{\sqrt{\mathrm{s}_{1}^{2} / \mathrm{n}_{1}+\mathrm{s}_{2}^{2} / \mathrm{n}_{2}}} \\
& v=\frac{\left(\frac{\mathrm{s}_{1}^{2}}{\mathrm{n}_{1}}+\frac{\mathrm{s}_{2}^{2}}{\mathrm{n}_{2}}\right)^{2}}{\frac{\left(\mathrm{s}_{1}^{2} / \mathrm{n}_{1}\right)^{2}}{\mathrm{n}_{1}+1}+\frac{\left(\mathrm{s}_{2}^{2} / \mathrm{n}_{2}\right)^{2}}{\mathrm{n}_{2}+1}}-2
\end{aligned}
$$

Assim definem-se abaixo as hipóteses a serem testadas e os critérios de rejeição para $\mathrm{H}_{0}$, neste caso, para o teste bilateral.

Hipótese Nula: $\mathrm{H}_{0}=\mu_{1}=\mu_{2}$

Hipótese Alternativa: $\mathrm{H}_{1}=\mu_{1} \neq \mu_{2}$

Critério de Rejeição da $\mathrm{H}_{0}: \mathrm{t}^{*}>\mathrm{t}_{0,025}$ ou $\mathrm{t}^{*}<-\mathrm{t}_{0,025}$ 


\section{A.2. RESULTADOS DA ANÁLISE}

Tabela A1 - Comparação entre as amostras do traço TR0 e dos traços do Grupo A - condição de aceitação da hipótese de igualdade (comparação entre duas amostras - variâncias desconhecidas, porém iguais)

\begin{tabular}{|c|c|c|c|c|c|c|c|c|c|}
\hline Traços & $\begin{array}{l}\text { Idade } \\
\text { ruptura } \\
\text { (dias) }\end{array}$ & $\begin{array}{c}\text { média } \\
\text { TRO }\end{array}$ & $s$ & $\sigma$ & $\mathbf{N}$ & $v$ & $t_{\alpha / 2}$ & $\mathbf{t}$ & $\begin{array}{c}\text { Rejeita } \\
\mathrm{H}_{0} ?\end{array}$ \\
\hline \multirow{4}{*}{ TRO } & 14 & 37,69 & 1,32 & & 4 & & & & \\
\hline & 28 & 42,53 & 1,91 & & 4 & & & & \\
\hline & 56 & 47,16 & 0,29 & & 2 & & & & \\
\hline & 91 & 46,88 & 4,95 & & 5 & & & & \\
\hline \multirow{4}{*}{ TR2A } & 14 & 37,69 & 1,32 & 1,49 & 5 & 7 & $\pm 2,365$ & $-3,969$ & SIM \\
\hline & 28 & 42,53 & 0,55 & 1,62 & 4 & 6 & $\pm 2,447$ & $-4,870$ & SIM \\
\hline & 56 & 47,16 & 1,77 & 1,78 & 4 & 4 & $\pm 2,776$ & $-3,228$ & SIM \\
\hline & 91 & 46,88 & 1,36 & 4,62 & 3 & 6 & $\pm 2,447$ & $-0,842$ & NÃO \\
\hline \multirow{4}{*}{ TR5A } & 14 & 37,69 & 1,14 & 1,42 & 4 & 6 & $\pm 2,447$ & $-12,786$ & SIM \\
\hline & 28 & 42,53 & 1,23 & 1,95 & 3 & 5 & $\pm 2,571$ & $-9,516$ & SIM \\
\hline & 56 & 47,16 & 2,12 & 2,13 & 4 & 4 & $\pm 2,776$ & $-8,020$ & SIM \\
\hline & 91 & 46,88 & 4,12 & 5,09 & 5 & 8 & $\pm 2,306$ & $-3,457$ & SIM \\
\hline \multirow{4}{*}{ TR10A } & 14 & 37,69 & 0,58 & 1,17 & 4 & 6 & $\pm 2,447$ & $-24,226$ & SIM \\
\hline & 28 & 42,53 & 1,55 & 2,01 & 4 & 6 & $\pm 2,447$ & $-16,179$ & SIM \\
\hline & 56 & 47,16 & 1,99 & 2,00 & 4 & 4 & $\pm 2,776$ & $-14,651$ & SIM \\
\hline & 91 & 46,88 & 1,39 & 4,06 & 5 & 8 & $\pm 2,306$ & $-9,238$ & SIM \\
\hline \multirow{4}{*}{ TR15A } & 14 & 37,69 & 0,96 & 1,28 & 5 & 7 & $\pm 2,365$ & $-27,194$ & SIM \\
\hline & 28 & 42,53 & 1,17 & 1,82 & 4 & 6 & $\pm 2,447$ & $-20,838$ & SIM \\
\hline & 56 & 47,16 & 1,57 & 1,58 & 4 & 4 & $\pm 2,776$ & $-23,861$ & SIM \\
\hline & 91 & 46,88 & 0,78 & 4,22 & 4 & 7 & $\pm 2,365$ & $-11,633$ & SIM \\
\hline \multirow{4}{*}{ TR20A } & 14 & 37,69 & 0,58 & 1,11 & 5 & 7 & $\pm 2,365$ & $-29,144$ & SIM \\
\hline & 28 & 42,53 & 1,06 & 1,89 & 3 & 5 & $\pm 2,571$ & $-18,513$ & SIM \\
\hline & 56 & 47,16 & 1,23 & 1,25 & 4 & 4 & $\pm 2,776$ & $-24,938$ & SIM \\
\hline & 91 & 46,88 & 1,34 & 4,30 & 4 & 7 & $\pm 2,365$ & $-9,172$ & SIM \\
\hline \multirow{4}{*}{ TR30A } & 14 & 37,69 & 0,67 & 1,21 & 4 & 6 & $\pm 2,447$ & $-31,984$ & SIM \\
\hline & 28 & 42,53 & 0,52 & 1,75 & 3 & 5 & $\pm 2,571$ & $-23,593$ & SIM \\
\hline & 56 & 47,16 & 1,41 & 1,42 & 4 & 4 & $\pm 2,776$ & $-28,523$ & SIM \\
\hline & 91 & 46,88 & 0,80 & 4,23 & 4 & 7 & $\pm 2,365$ & $-12,316$ & SIM \\
\hline
\end{tabular}


Tabela A2 - Comparação entre as amostras do traço TR0 e dos traços do Grupo B - condição de aceitação da hipótese de igualdade (comparação entre duas amostras - variâncias desconhecidas, porém iguais)

\begin{tabular}{|c|c|c|c|c|c|c|c|c|c|}
\hline Traços & $\begin{array}{c}\text { Idade } \\
\text { ruptura } \\
\text { (dias) }\end{array}$ & $\begin{array}{c}\text { média } \\
\text { TRO }\end{array}$ & $s$ & $\sigma$ & $\mathbf{N}$ & $v$ & $t_{\alpha / 2}$ & $\mathbf{t}$ & $\begin{array}{c}\text { Rejeita } \\
\mathrm{H}_{0} ?\end{array}$ \\
\hline \multirow{4}{*}{ TRO } & 14 & 37,69 & 1,32 & & 4 & & & & \\
\hline & 28 & 42,53 & 1,91 & & 4 & & & & \\
\hline & 56 & 47,16 & 0,29 & & 2 & & & & \\
\hline & 91 & 46,88 & 4,95 & & 5 & & & & \\
\hline \multirow{4}{*}{ TR2B } & 14 & 37,69 & 0,05 & 1,08 & 4 & 6 & $\pm 2,447$ & $-6,401$ & SIM \\
\hline & 28 & 42,53 & 1,45 & 1,89 & 5 & 7 & $\pm 2,365$ & $-5,158$ & SIM \\
\hline & 56 & 47,16 & 2,18 & 2,19 & 5 & 5 & $\pm 2,571$ & $-5,731$ & SIM \\
\hline & 91 & 46,88 & 1,26 & 4,04 & 5 & 8 & $\pm 2,306$ & $-1,460$ & NÃO \\
\hline \multirow{4}{*}{ TR5B } & 14 & 37,69 & 0,92 & 1,31 & 4 & 6 & $\pm 2,447$ & $-9,770$ & SIM \\
\hline & 28 & 42,53 & 2,62 & 2,64 & 5 & 7 & $\pm 2,365$ & $-7,116$ & SIM \\
\hline & 56 & 47,16 & 2,11 & 2,12 & 4 & 5 & $\pm 2,571$ & $-7,094$ & SIM \\
\hline & 91 & 46,88 & 2,61 & 4,42 & 5 & 8 & $\pm 2,306$ & $-3,073$ & SIM \\
\hline \multirow{4}{*}{ TR10B } & 14 & 37,69 & 1,20 & 1,42 & 5 & 7 & $\pm 2,365$ & $-18,941$ & SIM \\
\hline & 28 & 42,53 & 0,97 & 1,66 & 5 & 7 & $\pm 2,365$ & $-18,818$ & SIM \\
\hline & 56 & 47,16 & 1,08 & 1,10 & 5 & 5 & $\pm 2,571$ & $-24,839$ & SIM \\
\hline & 91 & 46,88 & 1,48 & 4,33 & 4 & 7 & $\pm 2,365$ & $-7,883$ & SIM \\
\hline \multirow{4}{*}{ TR15B } & 14 & 37,69 & 0,78 & 1,25 & 4 & 6 & $\pm 2,447$ & $-21,819$ & SIM \\
\hline & 28 & 42,53 & 0,37 & 1,47 & 5 & 7 & $\pm 2,365$ & $-21,343$ & SIM \\
\hline & 56 & 47,16 & 0,55 & 0,58 & 4 & 4 & $\pm 2,776$ & $-48,661$ & SIM \\
\hline & 91 & 46,88 & 2,48 & 4,85 & 3 & 6 & $\pm 2,447$ & $-7,654$ & SIM \\
\hline \multirow{4}{*}{ TR20B } & 14 & 37,69 & 1,93 & 1,91 & 5 & 7 & $\pm 2,365$ & $-16,887$ & SIM \\
\hline & 28 & 42,53 & 0,93 & 1,64 & 5 & 7 & $\pm 2,365$ & $-21,037$ & SIM \\
\hline & 56 & 47,16 & 0,63 & 0,66 & 4 & 4 & $\pm 2,776$ & $-45,018$ & SIM \\
\hline & 91 & 46,88 & 0,95 & 3,98 & 5 & 8 & $\pm 2,306$ & $-10,457$ & SIM \\
\hline \multirow{4}{*}{ TR30B } & 14 & 37,69 & 1,48 & 1,65 & 3 & 5 & $\pm 2,571$ & $-21,347$ & SIM \\
\hline & 28 & 42,53 & 1,04 & 1,88 & 3 & 5 & $\pm 2,571$ & $-20,434$ & SIM \\
\hline & 56 & 47,16 & 0,78 & 0,80 & 5 & 5 & $\pm 2,571$ & $-48,203$ & SIM \\
\hline & 91 & 46,88 & 0,60 & 3,94 & 5 & 8 & $\pm 2,306$ & $-12,875$ & SIM \\
\hline
\end{tabular}




\section{APÊNDICE B}

\section{RESULTADOS - SOLUBILIZAÇÃO E LIXIVIAÇÃO}

\section{B.1. ENSAIO DE SOLUBILIZAÇÃO DE RESÍDUOS SÓLIDOS NBR $10.006 / 04^{36}$}

\begin{tabular}{ccccc}
\hline PARÂMETRO & UNIDADE & RESULTADO & $\begin{array}{c}\text { LIMITE MÁXIMO } \\
\text { NO EXTRATO } \\
\text { (mg/L) }\end{array}$ & $\begin{array}{c}\text { LIMITE DE } \\
\text { DETECÇÃO }\end{array}$ \\
\hline ALUMÍNIO & $\mathrm{mg} \mathrm{Al} / \mathrm{L}$ & 0,12 & 0,2 & 0,01 \\
\hline CÁDMIO & $\mathrm{mg} \mathrm{Cd} / \mathrm{L}$ & $\underline{0,57}$ & 0,005 & 0,0006 \\
\hline CHUMBO & $\mathrm{mg} \mathrm{Pb} / \mathrm{L}$ & $\underline{1,39}$ & 0,01 & 0,01 \\
\hline CIANETOS & $\mathrm{mg} \mathrm{CN} / \mathrm{L}$ & $<\mathrm{LD}$ & 0,07 & 0,001 \\
\hline CLORETOS & $\mathrm{mg} \mathrm{Cl} / \mathrm{L}$ & $\underline{950,0}$ & 250,0 & 0,01 \\
\hline COBRE & $\mathrm{mg} \mathrm{Cu} / \mathrm{L}$ & 0,58 & 2,00 & 0,003 \\
\hline CROMO TOTAL & $\mathrm{mg} \mathrm{Cr} / \mathrm{L}$ & $\underline{3,09}$ & 0,05 & 0,005 \\
\hline FENÓIS TOTAIS & $\mathrm{mg} \mathrm{C} \mathrm{H}_{5} \mathrm{OH}$ & $\underline{0,042}$ & 0,01 & 0,001 \\
\hline FERRO TOTAL & $\mathrm{mg} \mathrm{Fe} / \mathrm{L}$ & $\underline{1,68}$ & 0,30 & 0,005 \\
\hline FLUORETOS & $\mathrm{mg} \mathrm{F} / \mathrm{L}$ & 0,12 & 1,50 & 0,01 \\
\hline MANGANÊS & $\mathrm{mg} \mathrm{Mn} / \mathrm{L}$ & $\underline{0,21}$ & 0,10 & 0,003 \\
\hline NITRATOS & $\mathrm{mg} \mathrm{N} / \mathrm{L}$ & $\underline{75,0}$ & 10,0 & 0,01 \\
\hline PRATA & $\mathrm{mg} \mathrm{Ag} / \mathrm{L}$ & $\underline{0,62}$ & 0,05 & 0,001 \\
\hline SÓDIO & $\mathrm{mg} \mathrm{Na/L}$ & $\underline{12175}$ & 200,0 & 0,1 \\
\hline SULFATOS & $\mathrm{mg} \mathrm{SO}{ }_{4}^{2-} / \mathrm{L}$ & $<\mathrm{LD}$ & 250,0 & 1 \\
\hline ZINCO & $\mathrm{mg} \mathrm{Zn/L}$ & 0,45 & 5,0 & 0,02 \\
\hline pH DO SOLUBILIZADO & & 12,63 & $\mathrm{~N} . \mathrm{A}$. & 0 \\
\hline
\end{tabular}

LIMITE MÁXIMO NO EXTRATO - ANEXO G (NORMATIVO) - PADRÕES PARA O ENSAIO DE SOLUBILIZAÇÃO (mg/L).

LD = LIMITE DE DETECÇÃO

N.A. = NÃO SE APLICA.

Resultados em Sublinhado - Valores acima do limite máximo no extrato.

\footnotetext{
${ }^{36}$ Ensaios efetuados de acordo com a $20^{a}$. edição do Standard Methods. Os resultados apresentados neste certificado referem-se exclusivamente às amostras enviadas ao laboratório, na data da coleta informada pelo interessado (Nota do Laboratório de Saneamento - EESC/USP).
} 


\section{B.2. ENSAIO DE LIXIVIAÇÃO DE RESÍDUOS SÓLIDOS} NBR $10.005 / 04^{37}$

\begin{tabular}{ccccc}
\hline PARÂMETRO & UNIDADE & RESULTADO & $\begin{array}{c}\text { LIMITE } \\
\text { MÁXIMO NO } \\
\text { LIXIVIADO }\end{array}$ & $\begin{array}{c}\text { LIMITE DE } \\
\text { DETECÇÃO }\end{array}$ \\
\hline CÁDMIO & $\mathrm{mg} \mathrm{Cd} / \mathrm{L}$ & 0,08 & 0,5 & 0,0006 \\
\hline CHUMBO & $\mathrm{mg} \mathrm{Pb} / \mathrm{L}$ & 0,45 & 1,0 & 0,01 \\
\hline CROMO TOTAL & $\mathrm{mg} \mathrm{Cr} / \mathrm{L}$ & 0,45 & 5,0 & 0,005 \\
\hline FLUORETOS & $\mathrm{mg} \mathrm{F} / \mathrm{L}$ & 2,10 & 150,0 & 0,01 \\
\hline PRATA & $\mathrm{mg} \mathrm{Ag} / \mathrm{L}$ & 0,07 & 5,0 & 0,001 \\
\hline pH DO LIXIVIADO & & 10,58 & N.A. & 0 \\
\hline
\end{tabular}

LIMITE MÁXIMO NO LIXIVIADO PARA OS COMPOSTOS INORGÂNICOS ANEXO F (NORMATIVO).

LD = LIMITE DE DETECÇÃO

N.A. $=$ NÃO SE APLICA. 


\section{APÊNDICE C}

\section{DIFRATOGRAMAS DAS PASTAS}

Neste item são apresentados os difratogramas das pastas, assim como a legenda contendo as espécies químicas identificadas.

Tabela C1 - Espécies químicas identificadas nos difratogramas

\begin{tabular}{ccc}
\hline $\mathbf{G}$ & Gorgeita & $\mathrm{K}_{2} \mathrm{Ca}_{5}\left(\mathrm{SO}_{4}\right) \cdot 6 \mathrm{H}_{2} \mathrm{O}$ \\
\hline $\mathbf{P}$ & Portlandita $\left(^{*}\right)$ & $\mathrm{Ca}(\mathrm{OH})_{2}$ \\
\hline $\mathbf{C}$ & Calcita & $\mathrm{CaO}$ \\
\hline $\mathbf{C A}$ & Carboaluminato & $3 \mathrm{CaO} \cdot \mathrm{Al}_{2} \mathrm{O}_{3} \cdot \mathrm{CaCO}_{3} \cdot 12 \mathrm{H}_{2} \mathrm{O}$ \\
\hline E & Etringita & $3 \mathrm{CaO} \cdot \mathrm{Al}_{2} \mathrm{O}_{3} \cdot 3 \mathrm{CaSO}_{4} \cdot 31 \mathrm{H}_{2} \mathrm{O}$ \\
\hline B & Bruchita & $\mathrm{CaPO}_{3}(\mathrm{OH}) \cdot 2 \mathrm{H}_{2} \mathrm{O}$ \\
\hline S & Silicato de cálcio anidro & Alita e Belita \\
\hline
\end{tabular}

$\left(^{*}\right)$ Portlandita $=$ Hidróxido de cálcio $-\mathrm{CH}$

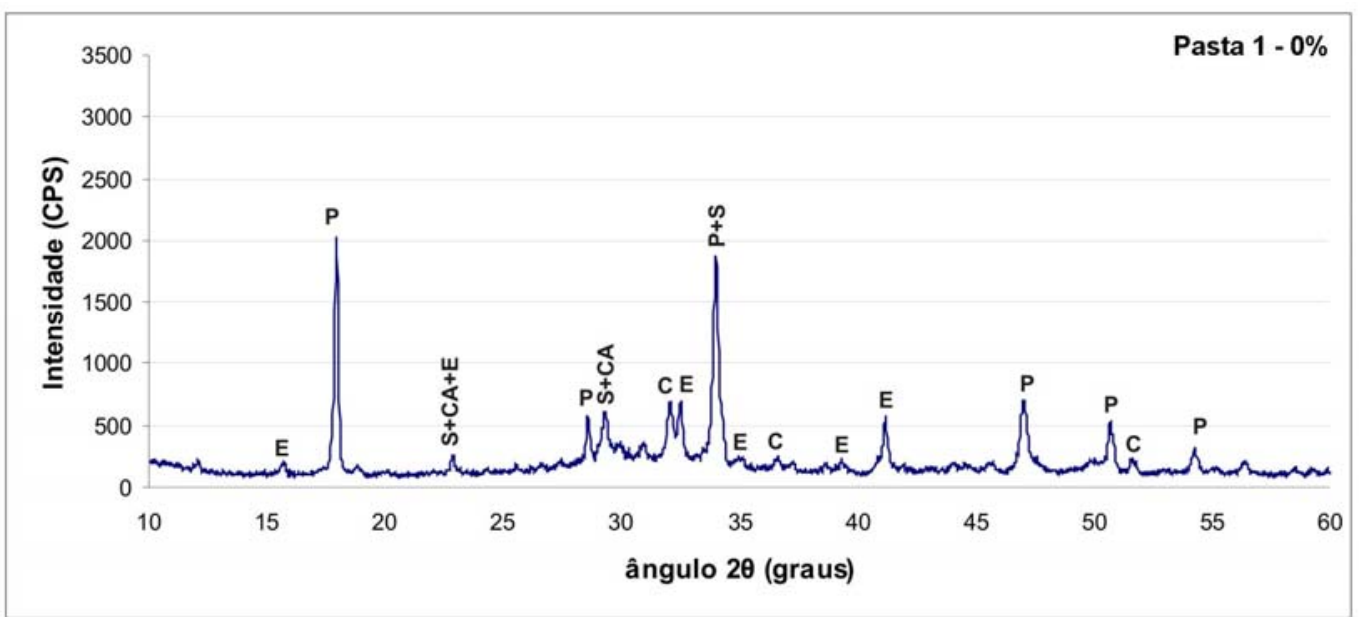

Figura C.1 - Difratograma de raios X da Pasta 1 


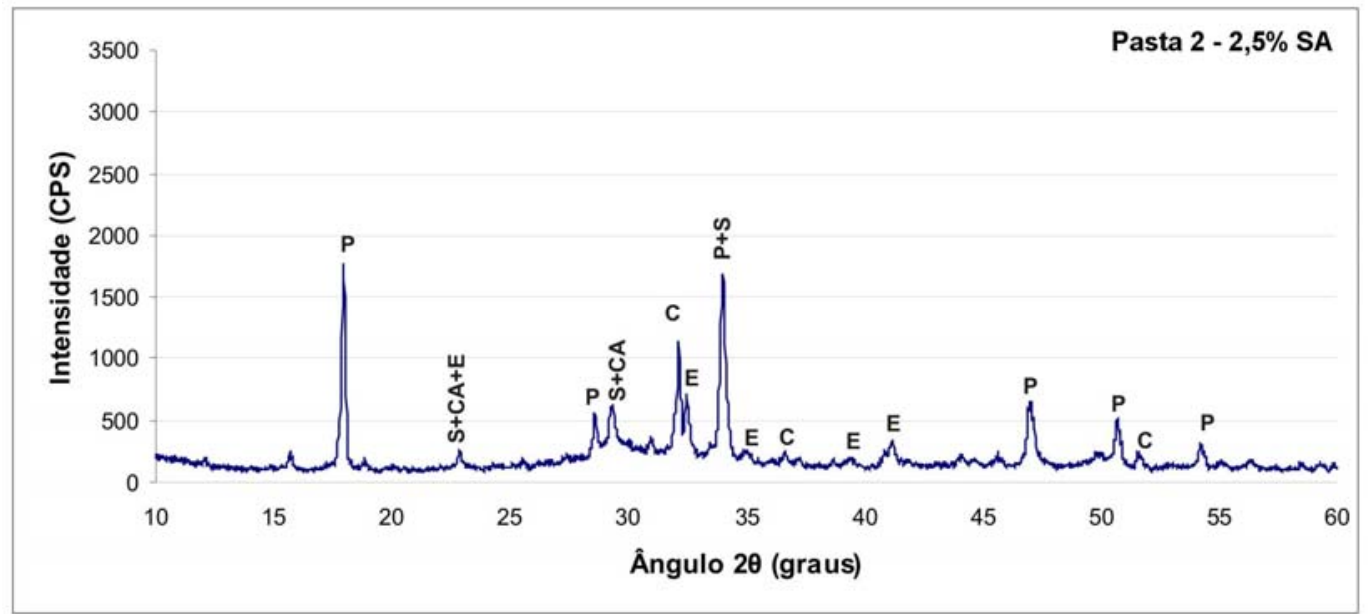

Figura C.2 - Difratograma de raios X da Pasta 2

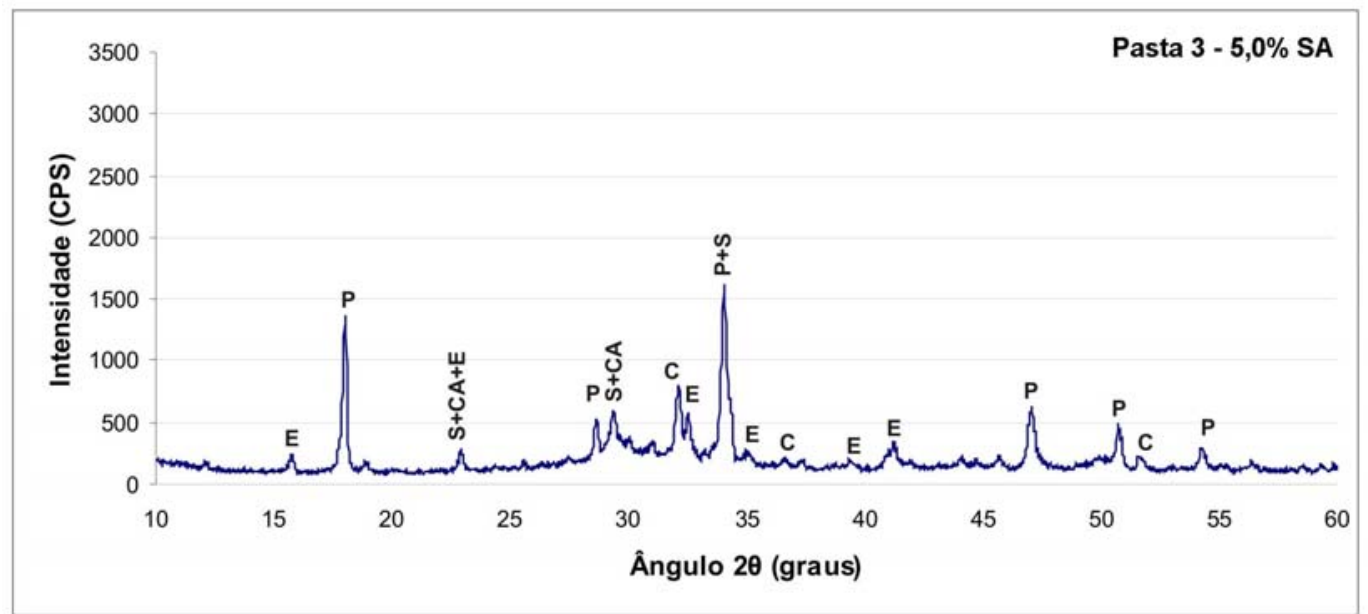

Figura C.3 - Difratograma de raios X da Pasta 3

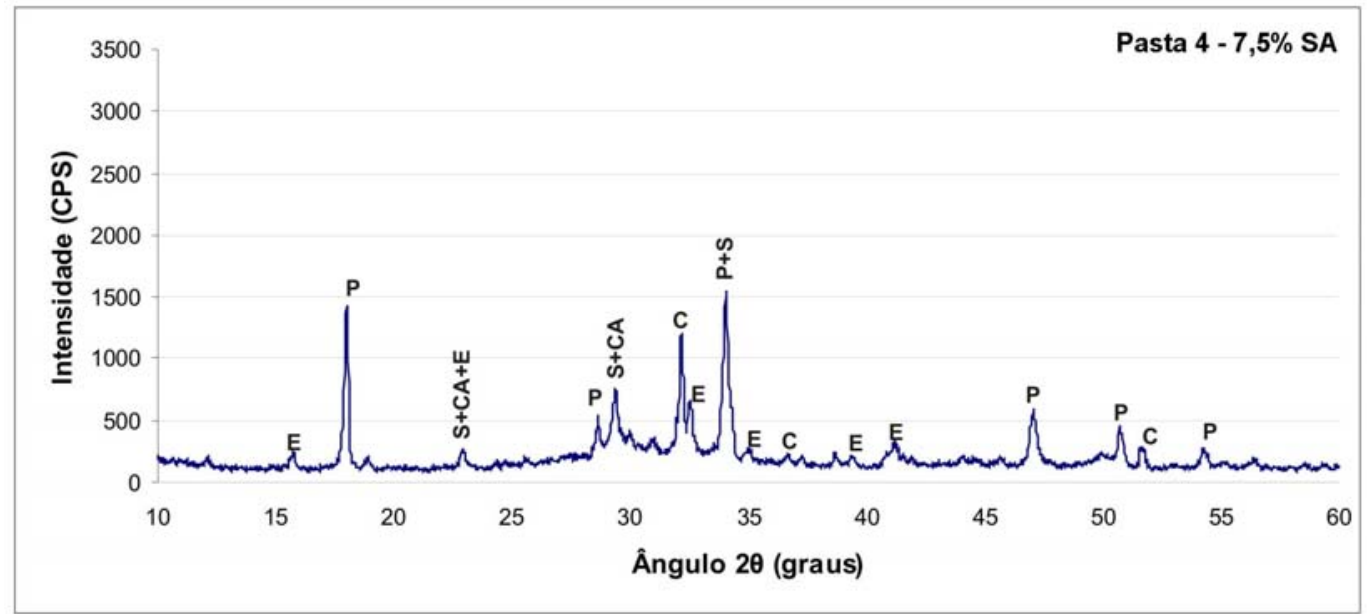

Figura C.4 - Difratograma de raios X da Pasta 4 


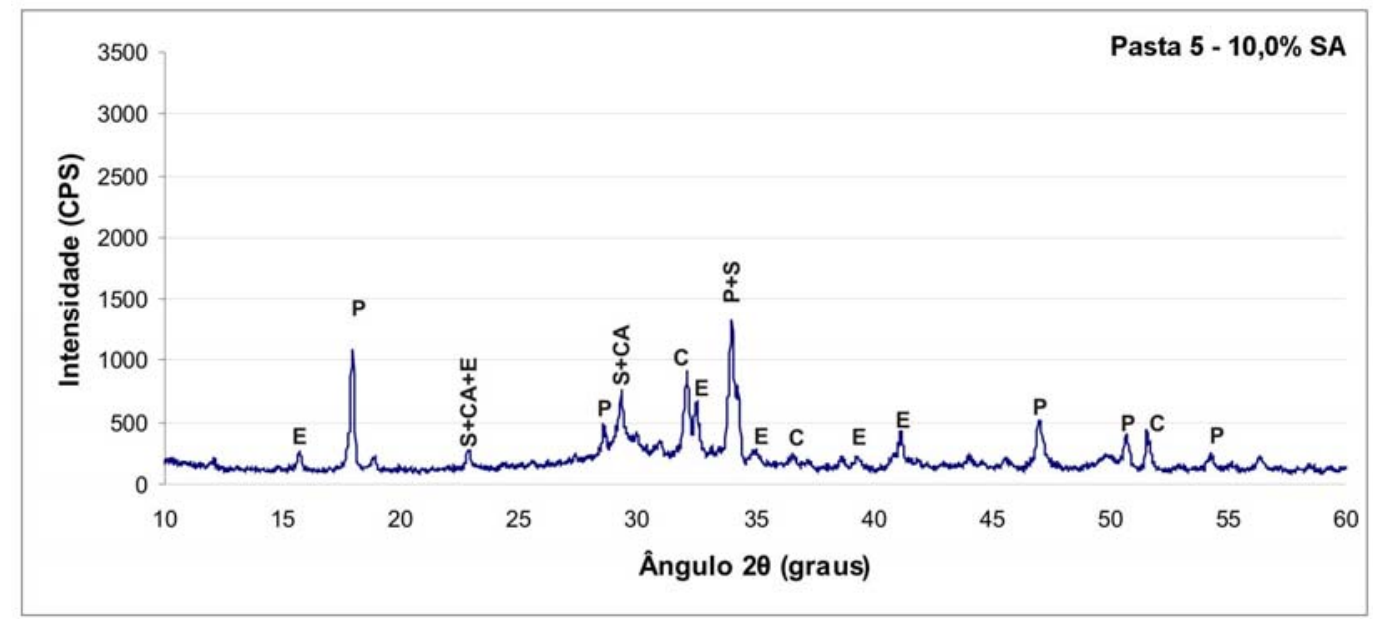

Figura C.5 - Difratograma de raios X da Pasta 5

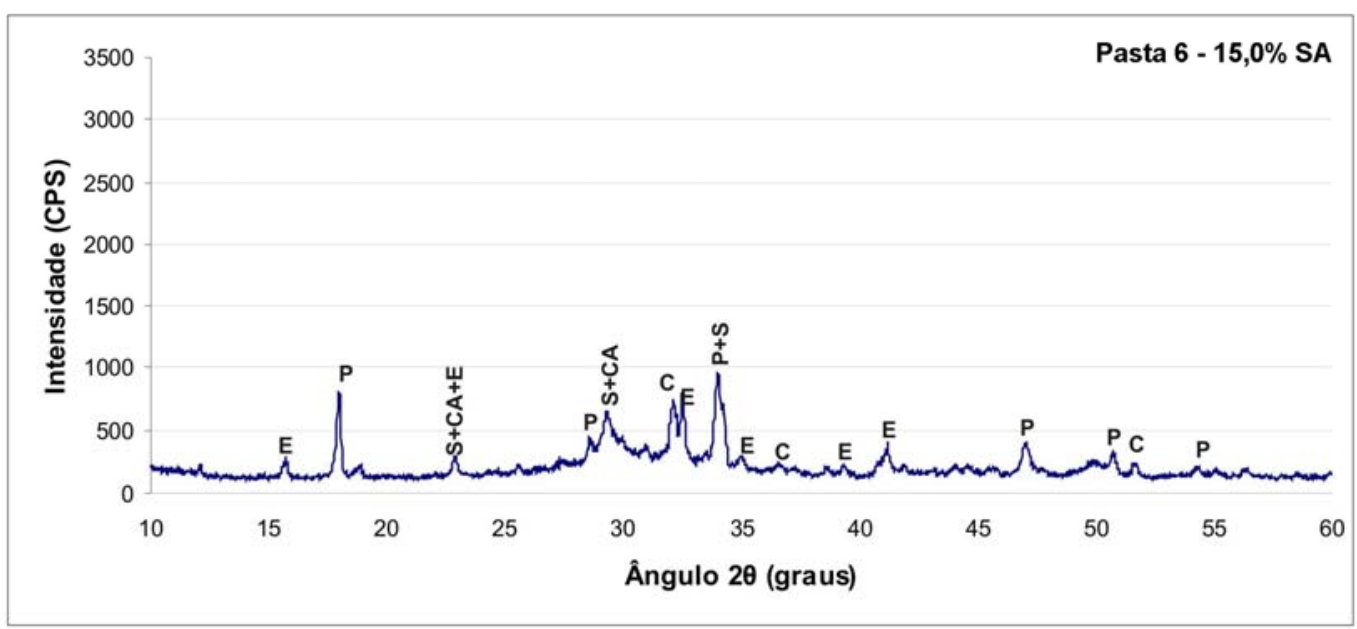

Figura C.6 - Difratograma de raios X da Pasta 6

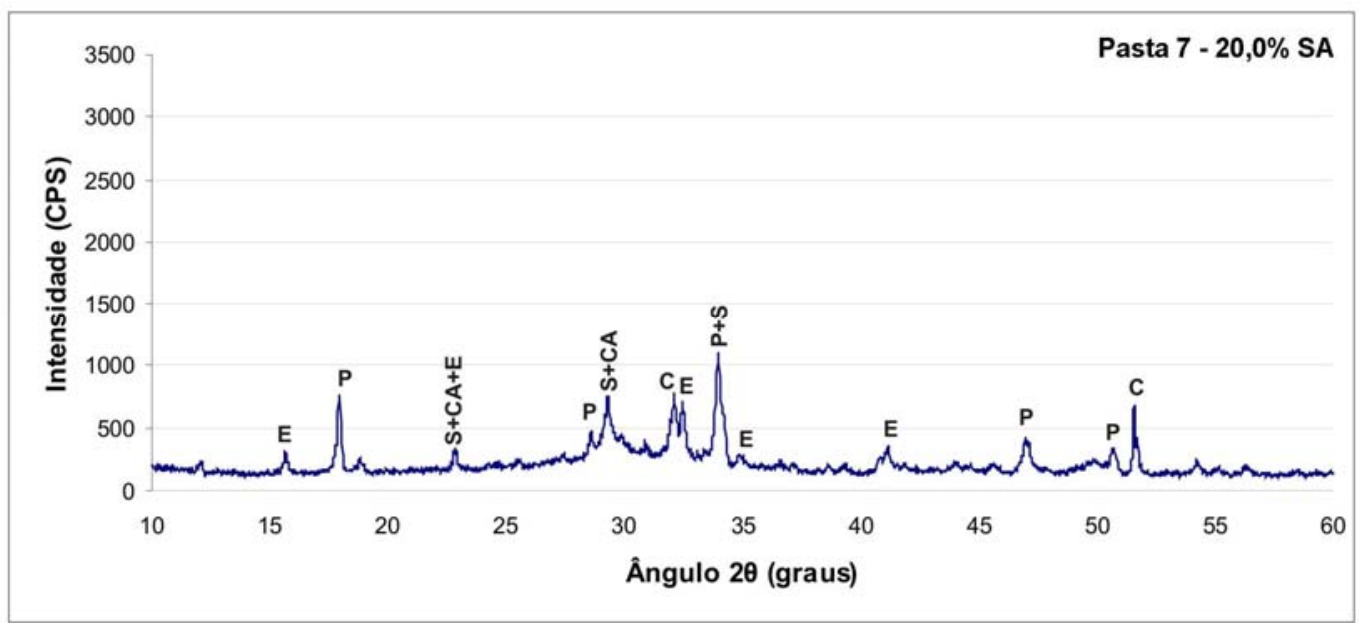

Figura C.7 - Difratograma de raios X da Pasta 7 


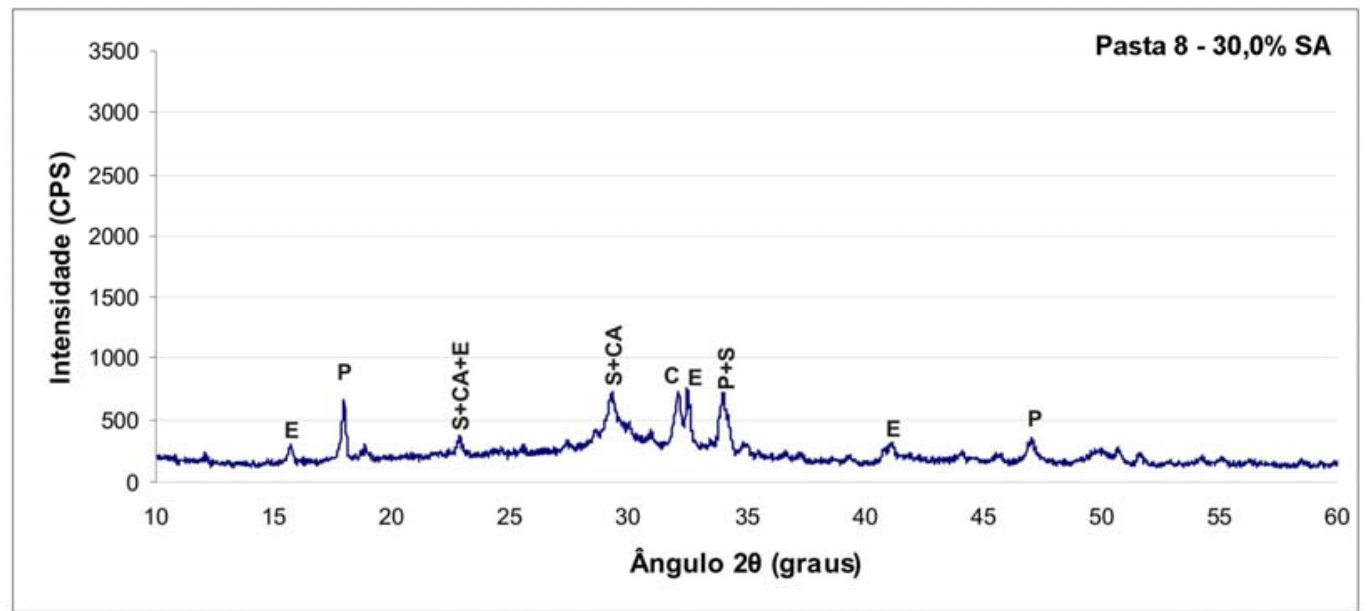

Figura C.8 - Difratograma de raios X da Pasta 8

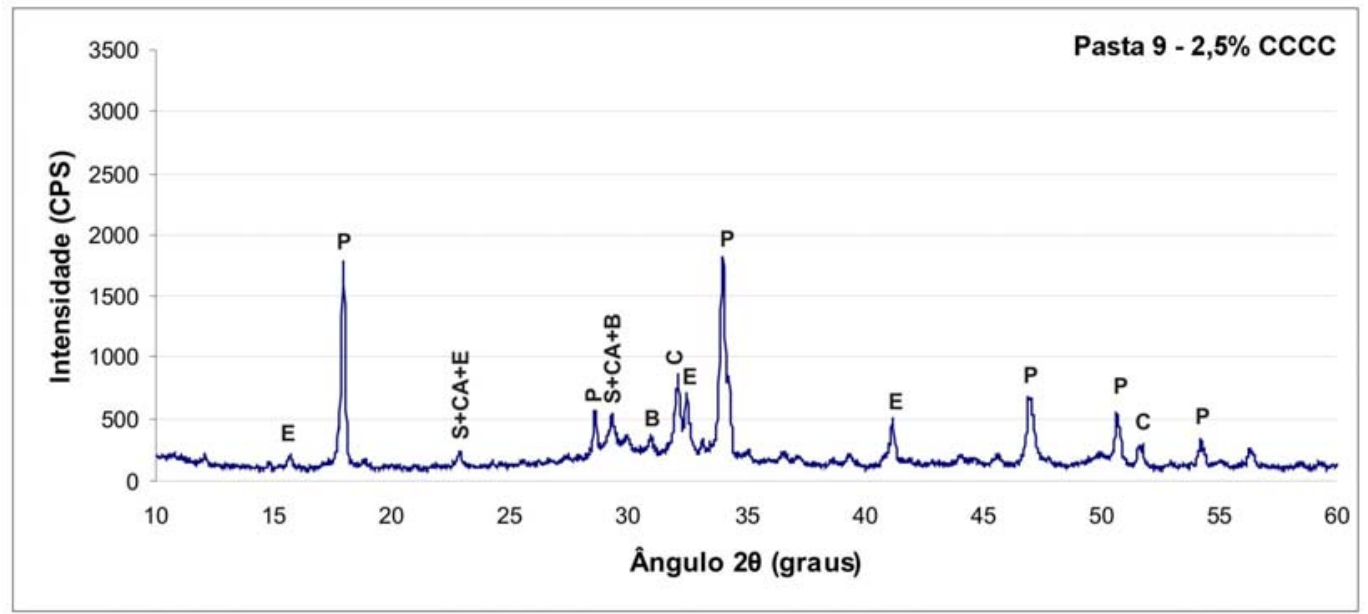

Figura C.9 - Difratograma de raios X da Pasta 9

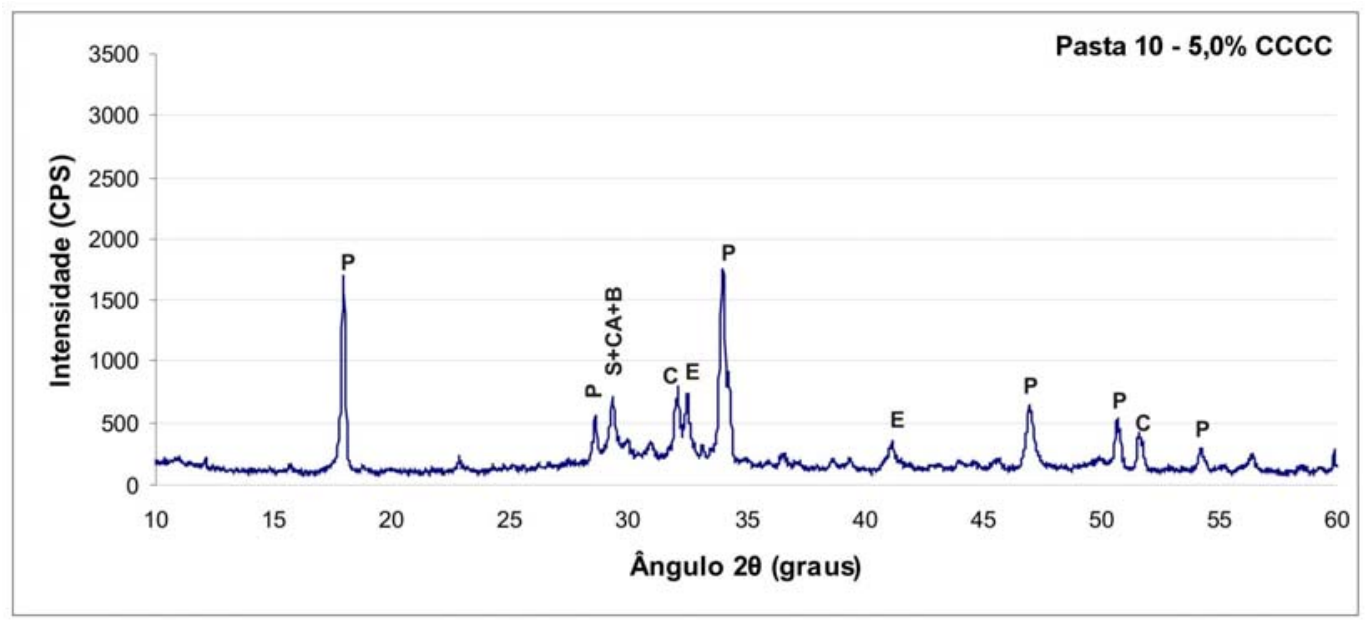

Figura C.10 - Difratograma de raios X da Pasta 10 


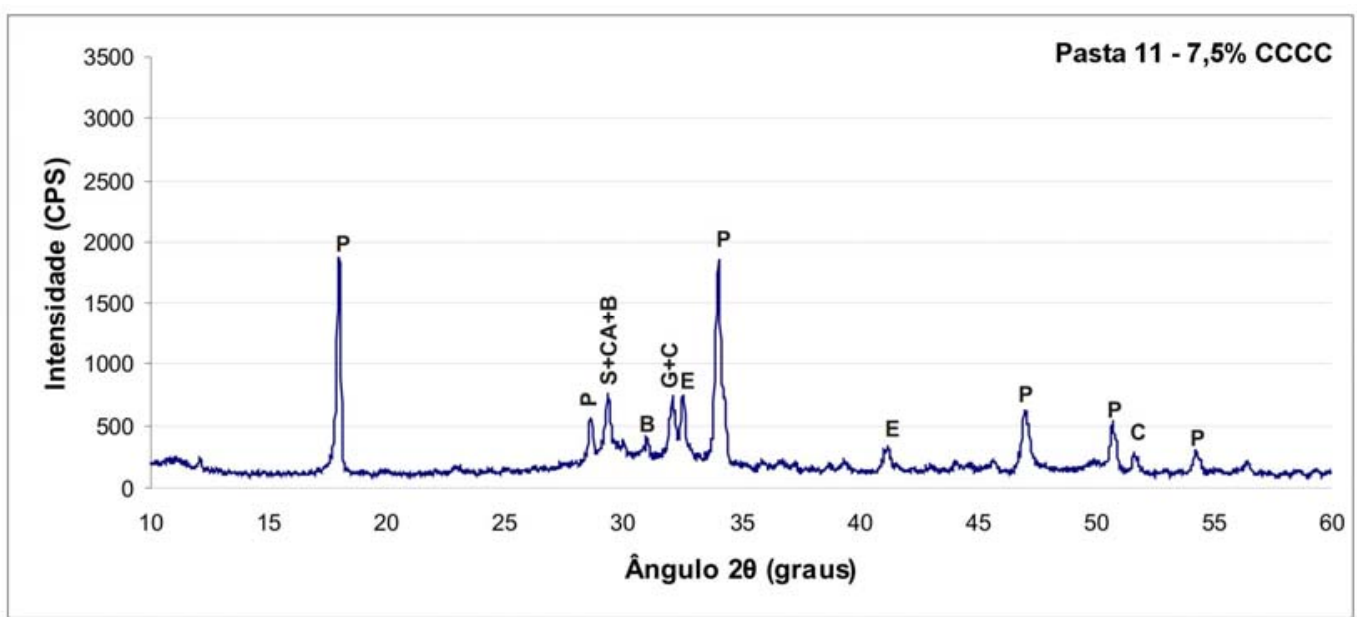

Figura C.11 - Difratograma de raios X da Pasta 11

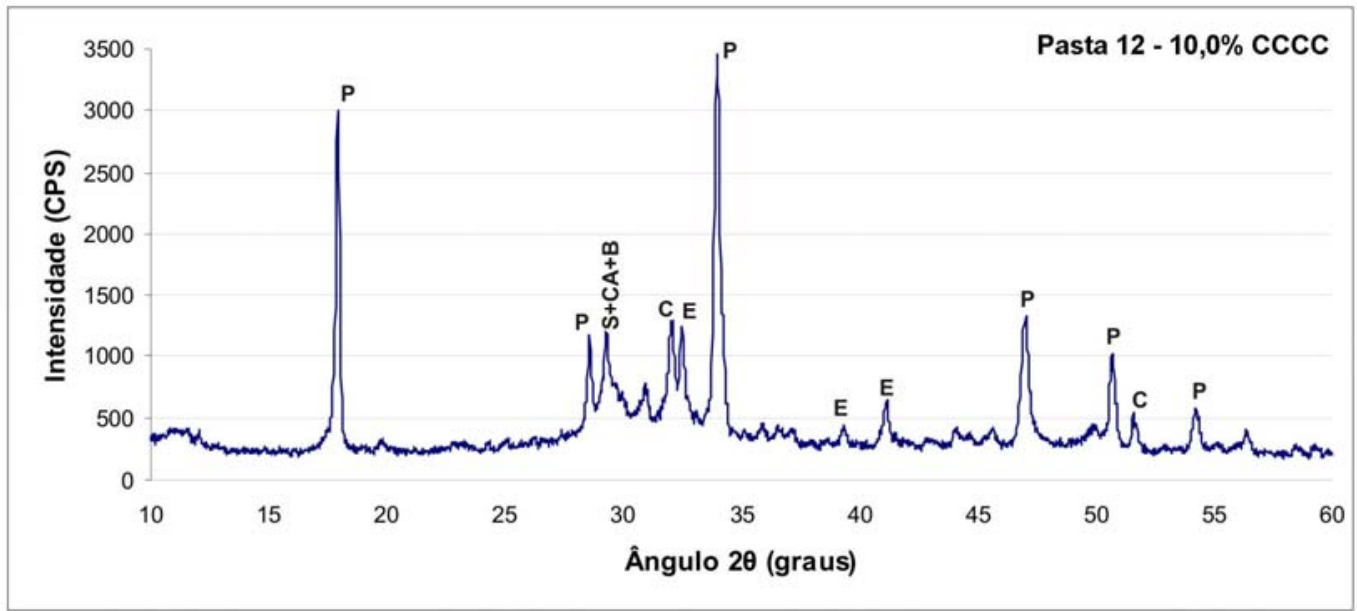

Figura C.12 - Difratograma de raios X da Pasta 12

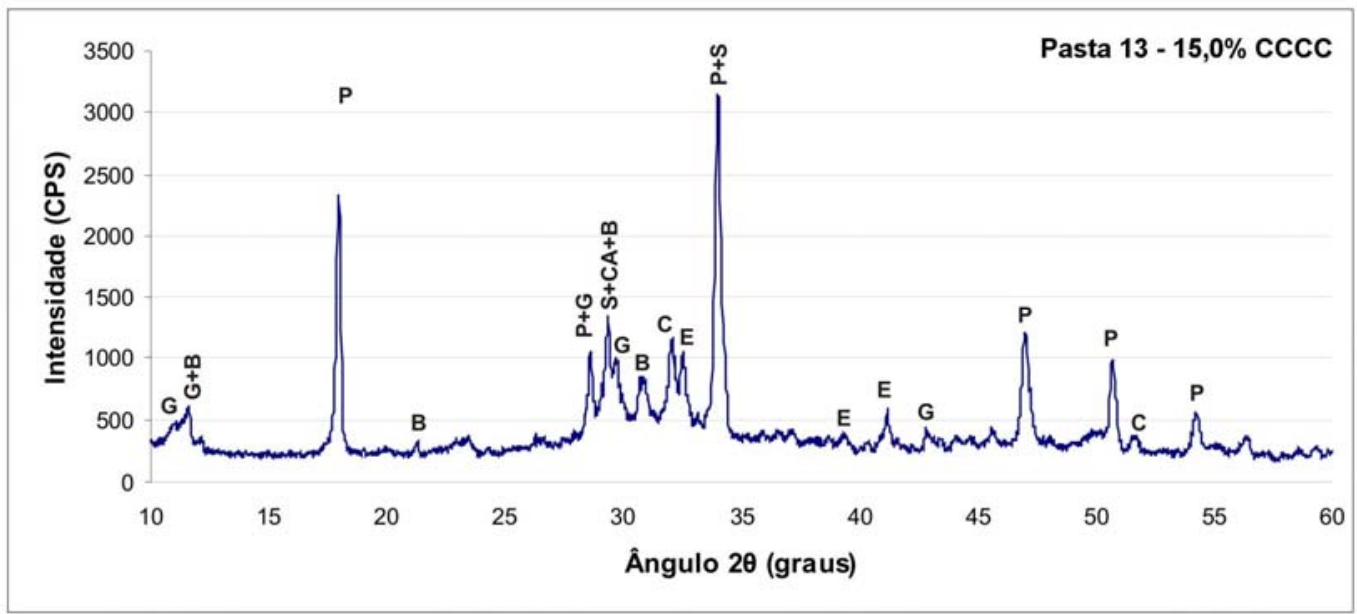

Figura C.13 - Difratograma de raios X da Pasta 13 


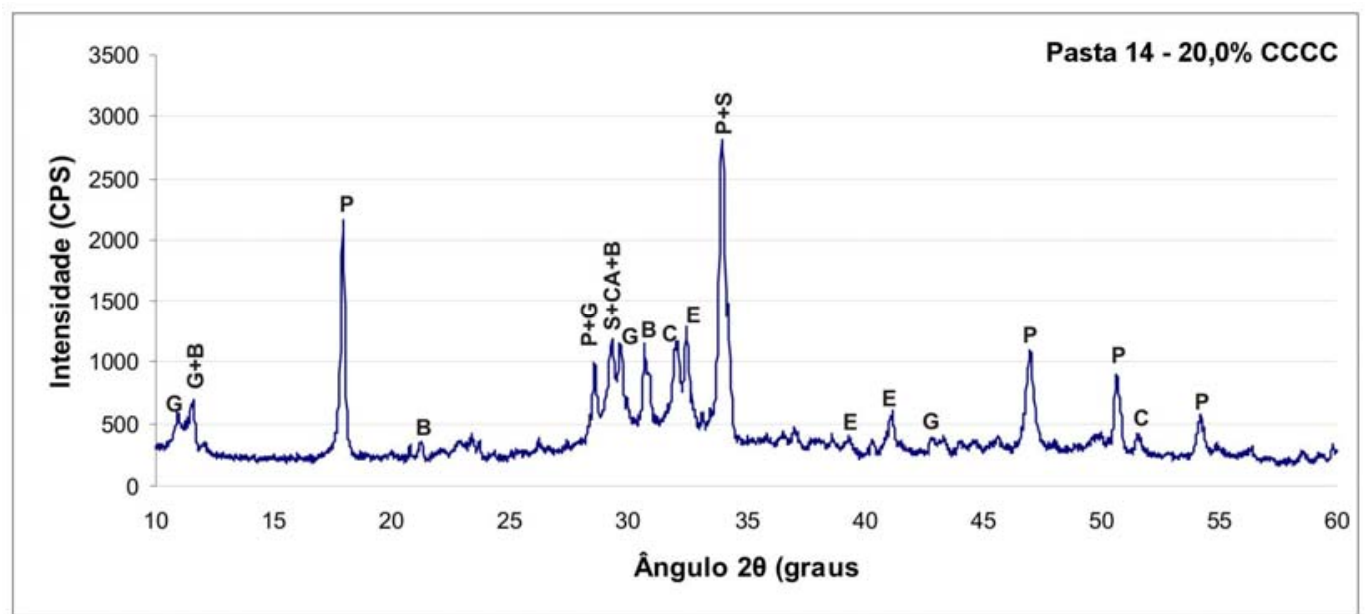

Figura C.14 - Difratograma de raios X da Pasta 14

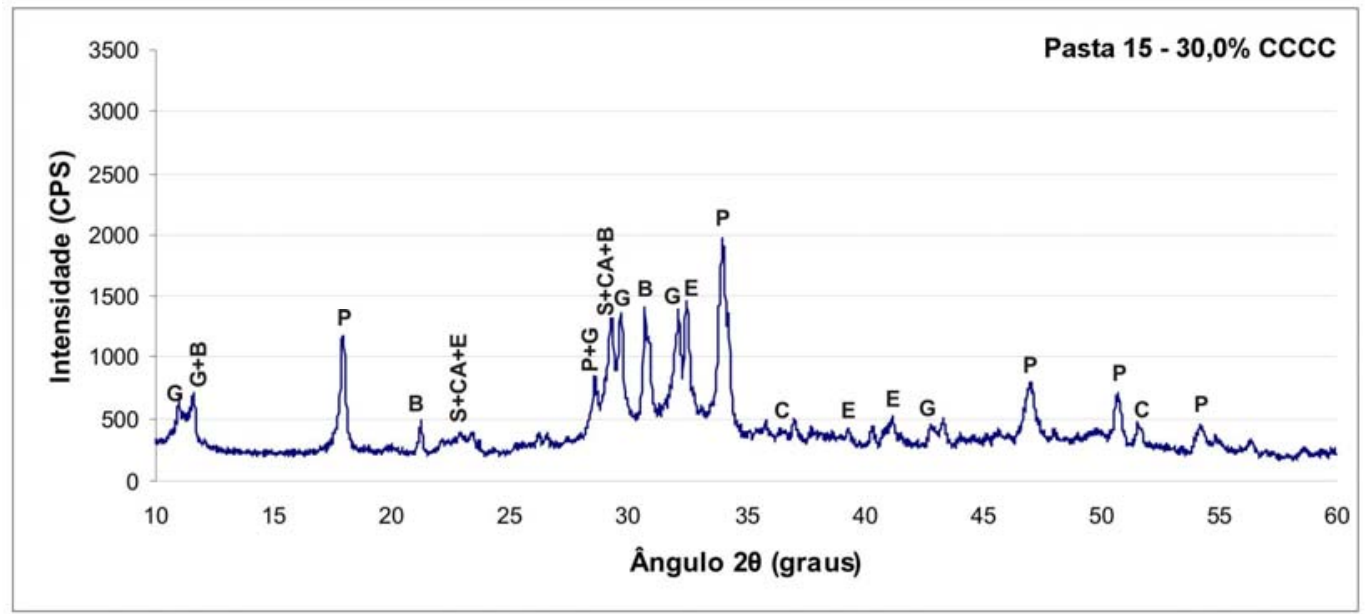

Figura C.15 - Difratograma de raios X da Pasta 15 


\section{APÊNDICE D}

\section{DADOS - ANÁLISE DO TEOR DE SUBSTITUIÇÃO}

\section{D.1. RESULTADOS OBTIDOS}

D.1.1. Ensaio de massa específica no estado fresco e teor de ar incorporado (NBR 13278)

Tabela D1 - Massa específica no estado fresco e teor de ar incorporado

\begin{tabular}{ccccccccc}
\hline $\mathbf{Q}$ água & $\begin{array}{c}\text { Fator } \\
\text { água/agl }\end{array}$ & Traço & Mt $(\mathbf{g})$ & $\mathbf{M r}(\mathbf{g})$ & $\mathbf{V r}\left(\mathbf{c m}_{3}\right)$ & $\begin{array}{c}\text { MEF } \\
\left(\mathbf{g} / \mathbf{c m}^{3}\right)\end{array}$ & $\begin{array}{c}\text { MET } \\
\left(\mathbf{g} / \mathbf{c m}^{3}\right)\end{array}$ & TA (\%) \\
\hline 663,75 & 0,590 & TR 0 & 1112,10 & 262,40 & 400 & 2,124 & 2,247 & 5,469 \\
\hline 663,75 & 0,590 & TR 2A & 1129,40 & 262,40 & 400 & 2,168 & 2,247 & 3,544 \\
\hline 674,00 & 0,594 & TR 5A & 1109,20 & 262,40 & 400 & 2,117 & 2,245 & 5,689 \\
\hline 685,00 & 0,608 & TR 10A & 1066,50 & 262,40 & 400 & 2,010 & 2,236 & 10,106 \\
\hline 685,00 & 0,608 & TR 15A & 1013,50 & 262,40 & 400 & 1,878 & 2,236 & 16,031 \\
\hline 685,00 & 0,608 & TR 20A & 1056,00 & 262,40 & 400 & 1,984 & 2,236 & 11,280 \\
\hline 685,00 & 0,608 & TR 30A & 1021,50 & 262,40 & 400 & 1,898 & 2,236 & 15,137 \\
\hline 663,75 & 0,590 & TR 2B & 1091,00 & 262,40 & 400 & 2,072 & 2,247 & 7,817 \\
\hline 674,00 & 0,594 & TR 5B & 1054,85 & 262,40 & 400 & 1,981 & 2,245 & 11,743 \\
\hline 685,00 & 0,608 & TR 10B & 1083,90 & 262,40 & 400 & 2,054 & 2,236 & 8,161 \\
\hline 685,00 & 0,608 & TR 15B & 1078,25 & 262,40 & 400 & 2,040 & 2,236 & 8,793 \\
\hline 685,00 & 0,608 & TR 20B & 1073,35 & 262,40 & 400 & 2,027 & 2,236 & 9,341 \\
\hline 685,00 & 0,608 & TR 30B & 1069,50 & 262,40 & 400 & 2,018 & 2,236 & 9,771 \\
\hline
\end{tabular}

Onde:

$\mathrm{Mr}$ - massa do recipiente

$\mathrm{Vr}$ - volume do recipiente

$\mathrm{Mt}$ - massa total (argamassa + recipiente)

MEF - massa específica obtida em laboratório

MET - massa específica teórica

TA - teor de ar incorporado 
D.1.2. Valores obtidos no ensaio de resistência à compressão

Tabela D2 - Valores individuais e médias - Grupo A ${ }^{38}$

\begin{tabular}{|c|c|c|c|c|c|c|c|}
\hline Traço & Idade & & & Resultado & & & $\begin{array}{l}\text { Média simples } \\
\text { (MPa) }\end{array}$ \\
\hline \multirow{4}{*}{ TR 0} & 14 & 38,01 & 36,57 & 34,02 & 39,42 & 36,77 & 37,69 \\
\hline & 28 & $\underline{38,29}$ & 44,41 & 41,15 & 43,90 & 40,64 & 42,53 \\
\hline & 56 & 47,36 & $\underline{29,74}$ & 46,95 & 36,47 & 33,71 & 47,16 \\
\hline & 91 & 46,24 & 49,61 & $\underline{38,50}$ & 49,71 & 50,32 & 48,97 \\
\hline \multirow{4}{*}{ TR 2 A } & 14 & 33,10 & 32,50 & 35,14 & 35,14 & 32,70 & 33,72 \\
\hline & 28 & 36,97 & 37,38 & $\underline{30,56}$ & 37,28 & 36,16 & 36,95 \\
\hline & 56 & 41,25 & 33,92 & 40,44 & 42,48 & 44,51 & 42,17 \\
\hline & 91 & 32,49 & 42,48 & 44,61 & 45,02 & 32,29 & 44,04 \\
\hline \multirow{4}{*}{ TR 5 A } & 14 & 23,63 & 28,01 & 24,75 & 24,64 & 26,38 & 24,85 \\
\hline & 28 & $\underline{32,18}$ & 28,41 & 29,54 & 27,09 & $\underline{32,70}$ & 28,35 \\
\hline & 56 & $\underline{27,70}$ & 34,94 & 30,25 & 33,20 & 31,07 & 32,37 \\
\hline & 91 & $\underline{31,27}$ & 34,33 & $\underline{42,27}$ & 34,22 & 36,67 & 35,75 \\
\hline \multirow{4}{*}{ TR $10 \mathrm{~A}$} & 14 & 17,21 & 17,51 & 14,56 & 18,43 & 17,21 & 17,59 \\
\hline & 28 & 18,33 & 14,56 & 18,74 & 19,46 & 21,80 & 19,58 \\
\hline & 56 & 23,94 & 17,42 & 22,61 & 21,49 & 19,25 & 21,82 \\
\hline & 91 & 24,75 & 24,14 & 22,61 & 21,19 & 23,02 & 23,14 \\
\hline \multirow{4}{*}{ TR $15 \mathrm{~A}$} & 14 & 13,44 & 15,68 & 13,54 & 13,95 & 14,87 & 14,30 \\
\hline & 28 & 15,48 & 15,08 & 17,32 & 11,00 & 14,67 & 15,08 \\
\hline & 56 & 16,80 & 13,44 & $\underline{12,52}$ & 13,54 & 14,36 & 14,54 \\
\hline & 91 & 14,26 & 13,04 & 13,55 & 14,82 & 10,19 & 13,92 \\
\hline \multirow{4}{*}{ TR $20 \mathrm{~A}$} & 14 & 16,50 & 15,88 & 16,60 & 15,17 & 15,78 & 15,99 \\
\hline & 28 & 15,18 & 13,24 & 15,18 & 17,01 & 11,20 & 15,79 \\
\hline & 56 & 20,57 & 19,35 & 21,80 & 16,50 & 19,14 & 20,22 \\
\hline & 91 & $\underline{13,24}$ & 20,98 & 19,05 & 19,56 & 22,00 & 20,40 \\
\hline \multirow{4}{*}{ TR $30 \mathrm{~A}$} & 14 & 11,30 & 9,77 & 10,08 & 10,59 & $\underline{8,25}$ & 10,44 \\
\hline & 28 & 11,41 & $\underline{8,86}$ & 10,39 & 13,14 & 11,10 & 11,51 \\
\hline & 56 & 14,15 & $\underline{9,27}$ & 11,61 & 11,10 & 11,40 & 12,07 \\
\hline & 91 & $\underline{9,98}$ & 12,83 & 11,51 & 11,10 & 12,43 & 11,97 \\
\hline
\end{tabular}

Onde:

Números sublinhados - valores excluídos por apresentarem desvio relativo máximo > 6\% (NBR 7215/96) Demais números - valores válidos.

\footnotetext{
${ }^{38}$ Idem à nota 32.
} 
Tabela D3 - Valores individuais e médias - Grupo B ${ }^{39}$

\begin{tabular}{|c|c|c|c|c|c|c|c|}
\hline Traço & Idade & & & Resultado & & & $\begin{array}{l}\text { Média simples } \\
(\mathrm{MPa})\end{array}$ \\
\hline \multirow{4}{*}{ TR 0} & 14 & 38,01 & 36,57 & 34,02 & 39,42 & 36,77 & 37,69 \\
\hline & 28 & $\underline{38,29}$ & 44,41 & 41,15 & 43,90 & 40,64 & 42,53 \\
\hline & 56 & 47,36 & $\underline{29,74}$ & 46,95 & $\underline{36,47}$ & 33,71 & 47,16 \\
\hline & 91 & 46,24 & 49,61 & $\underline{38,50}$ & 49,71 & 50,32 & 48,97 \\
\hline \multirow{4}{*}{ TR 2 B } & 14 & $\underline{24,04}$ & 32,90 & 32,80 & 33,80 & 32,10 & 32,90 \\
\hline & 28 & 37,89 & 34,73 & 34,32 & 36,36 & 36,57 & 35,97 \\
\hline & 56 & 40,03 & 35,24 & 34,83 & 37,68 & 35,54 & 36,66 \\
\hline & 91 & 41,46 & 43,09 & 42,98 & 45,02 & 43,19 & 43,15 \\
\hline \multirow{4}{*}{ TR 5 B } & 14 & 13,24 & 28,83 & 27,81 & 28,01 & 29,84 & 28,62 \\
\hline & 28 & 26,89 & 29,13 & 33,82 & 30,96 & 28,72 & 29,90 \\
\hline & 56 & $\underline{16,20}$ & 36,16 & 34,73 & 34,42 & 31,16 & 34,12 \\
\hline & 91 & 42,07 & 36,87 & 35,04 & 38,91 & 38,50 & 38,28 \\
\hline \multirow{4}{*}{ TR $10 \mathrm{~B}$} & 14 & 18,13 & 20,26 & 19,56 & 21,29 & 19,05 & 19,66 \\
\hline & 28 & 21,39 & 21,28 & 21,08 & 23,32 & 20,98 & 21,61 \\
\hline & 56 & 23,73 & 25,97 & 23,83 & 23,22 & 24,75 & 24,30 \\
\hline & 91 & 22,41 & $\underline{15,38}$ & 25,97 & 23,94 & 23,63 & 23,99 \\
\hline \multirow{4}{*}{ TR 15 B } & 14 & 19,25 & 18,02 & $\underline{14,36}$ & 17,52 & 18,84 & 18,41 \\
\hline & 28 & 21,79 & 20,98 & 21,08 & 21,69 & 21,59 & 21,43 \\
\hline & 56 & $\underline{18,53}$ & 22,51 & 22,00 & 22,51 & 23,32 & 22,59 \\
\hline & 91 & $\underline{15,38}$ & 22,00 & 20,27 & $\underline{13,75}$ & 17,11 & 19,79 \\
\hline \multirow{4}{*}{ TR $20 \mathrm{~B}$} & 14 & 14,87 & 13,85 & 15,28 & 17,62 & 18,44 & 16,01 \\
\hline & 28 & 20,47 & 20,16 & 18,64 & 18,33 & 19,25 & 19,37 \\
\hline & 56 & 21,08 & $\underline{11,71}$ & 21,39 & 21,08 & 22,40 & 21,49 \\
\hline & 91 & 20,07 & 20,88 & 21,90 & 20,47 & 19,35 & 20,53 \\
\hline \multirow{4}{*}{ TR 30 B } & 14 & 11,51 & 12,12 & 11,92 & 9,17 & 8,76 & 10,70 \\
\hline & 28 & $\underline{9,27}$ & $\underline{8,76}$ & 13,34 & 14,05 & 12,01 & 13,13 \\
\hline & 56 & 15,63 & 14,15 & 15,99 & 14,66 & 14,56 & 15,00 \\
\hline & 91 & 14,06 & 14,36 & 15,48 & 14,77 & 15,28 & 14,79 \\
\hline
\end{tabular}

Onde:

Números sublinhados - valores excluídos por apresentarem desvio relativo máximo > 6\% (NBR 7215/96)

Demais números - valores válidos.

${ }^{39}$ Idem à nota 32. 


\section{APÊNDICE E}

\section{FIGURAS - ENSAIO DE CARBONATAÇÃO}

São apresentadas, neste apêndice, as imagens das amostras utilizadas nos ensaios de profundidade de carbonatação com teores de CCCC entre 0\% e 30\%.

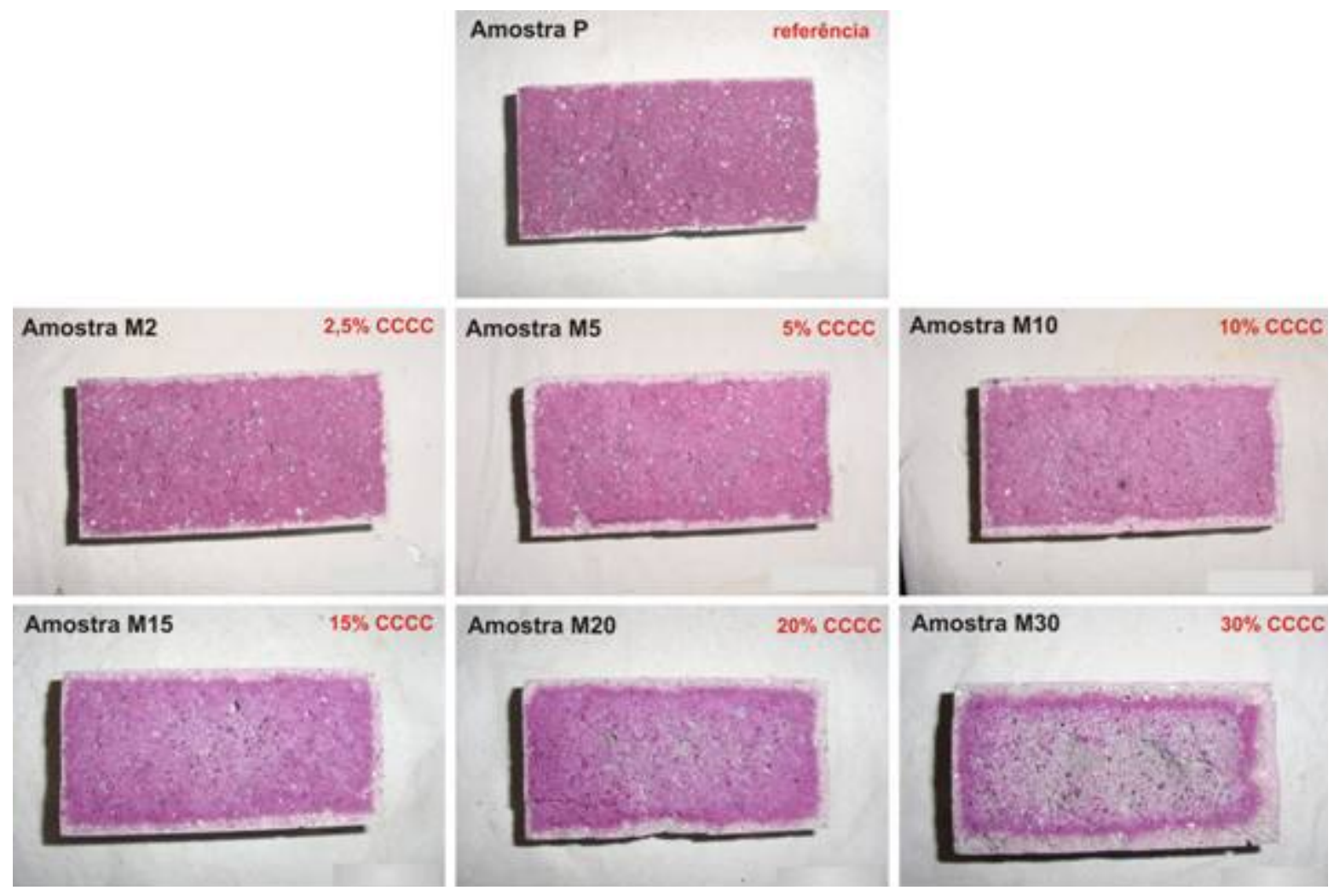

Figura E1 - Ensaio de carbonatação pelo método colorimétrico aos 90 dias Grupo A (cinza moída) 


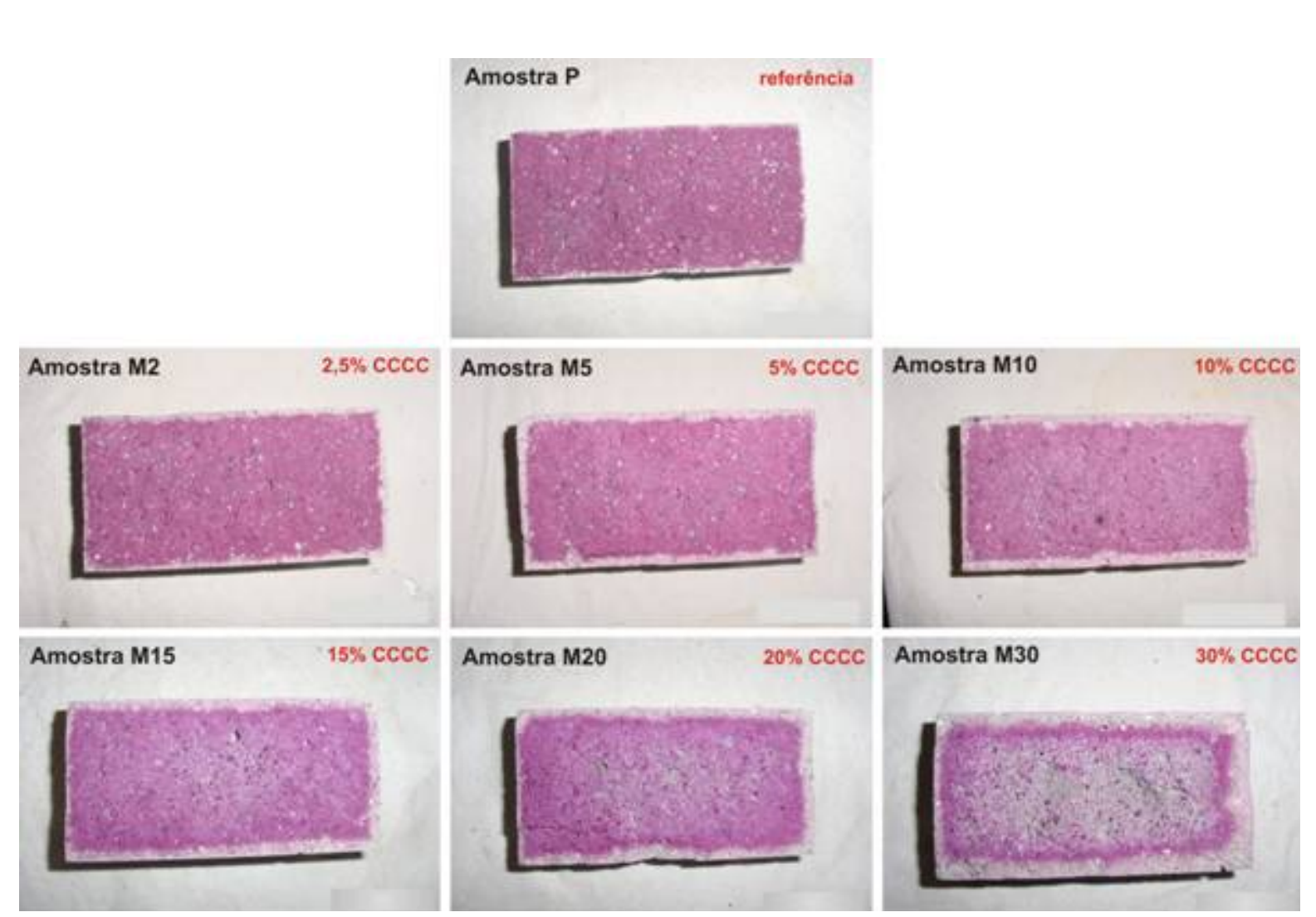

Figura E2 - Ensaio de carbonatação pelo método colorimétrico aos 90 dias Grupo B (cinza moída e peneirada)

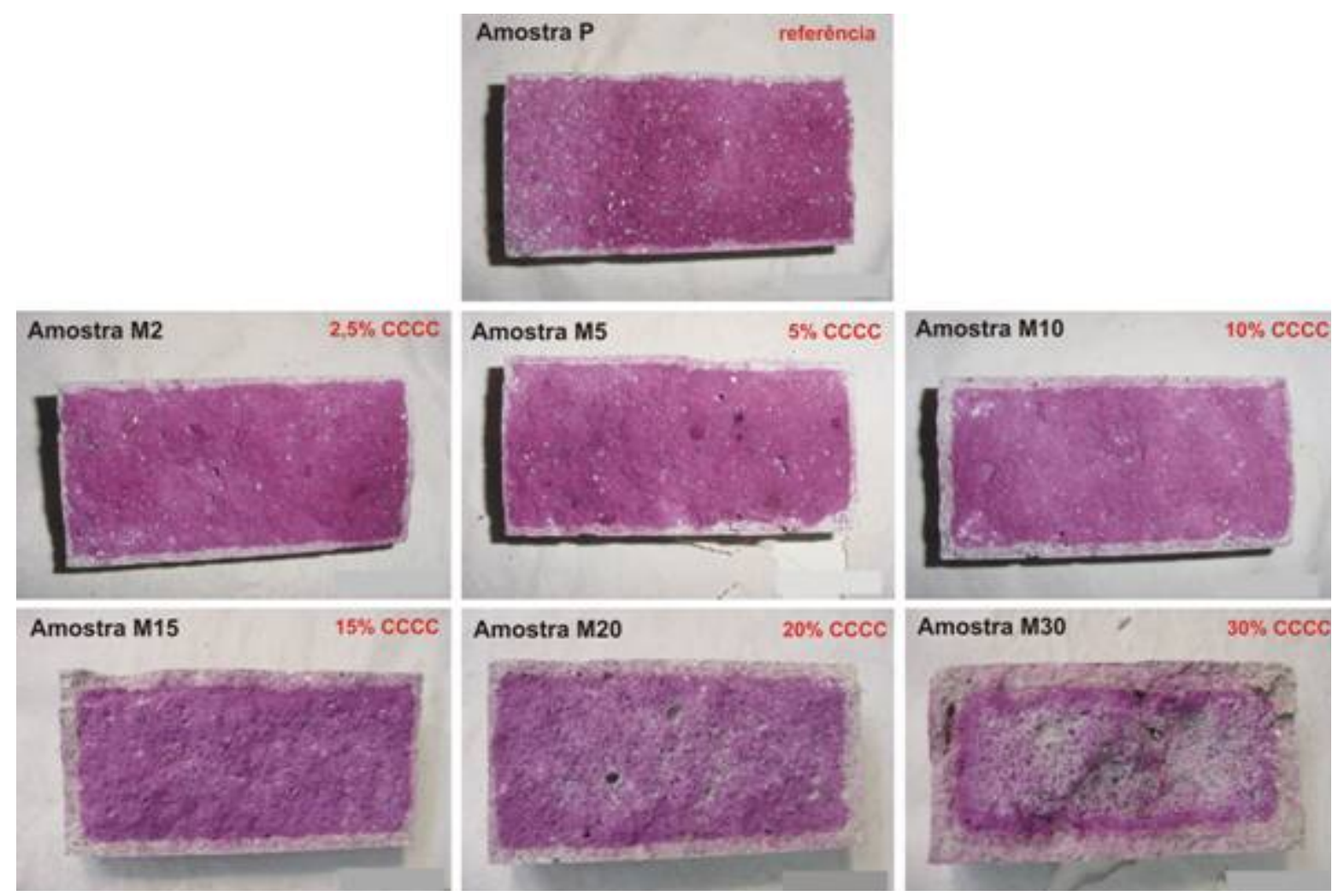

Figura E3 - Ensaio de carbonatação pelo método colorimétrico aos 180 dias Grupo A (cinza moída) 


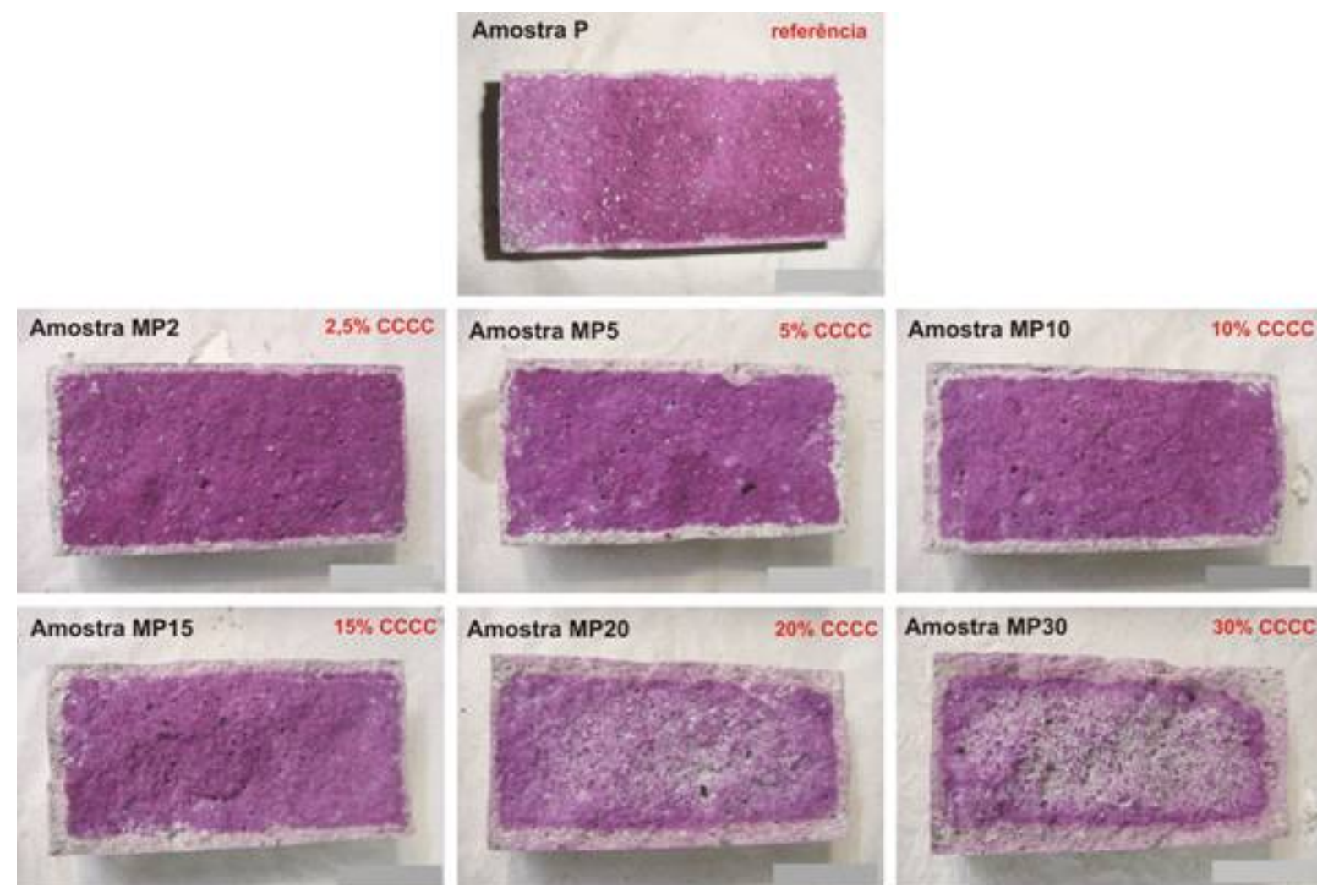

Figura E4 - Ensaio de carbonatação pelo método colorimétrico aos 180 dias Grupo B (cinza moída e peneirada) 


\section{APÊNDICE F}

\section{RESULTADOS - SOLUBILIZAÇÃO DAS PASTAS}

\section{F.1. ENSAIO DE SOLUBILIZAÇÃO DE RESÍDUOS SÓLIDOS NBR 10.006/04}

\begin{tabular}{|c|c|c|c|c|c|c|c|}
\hline \multirow{2}{*}{ PARÂMETRO } & \multirow{2}{*}{ UNIDADE } & \multicolumn{4}{|c|}{ Pastas - \% CCCC utilizada } & \multirow{2}{*}{$\begin{array}{l}\text { LIMITE MÁXIMO } \\
\text { NO EXTRATO } \\
\text { (mg/L) }\end{array}$} & \multirow{2}{*}{$\begin{array}{l}\text { LIMITE DE } \\
\text { DETECÇÃO }\end{array}$} \\
\hline & & $0 \%$ & $2,5 \%$ & $5 \%$ & $10 \%$ & & \\
\hline ALUMÍNIO & $\mathrm{mg} \mathrm{Al} / \mathrm{L}$ & 0,14 & 0,16 & 0,18 & $\underline{0,25}$ & 0,20 & 0,01 \\
\hline CÁDMIO & $\mathrm{mg} \mathrm{Cd} / \mathrm{L}$ & $<\mathrm{LD}$ & $<$ LD & $<\mathrm{LD}$ & $<$ LD & 0,005 & 0,0006 \\
\hline CHUMBO & $\mathrm{mg} \mathrm{Pb/L}$ & $<\mathrm{LD}$ & $<L D$ & $<\mathrm{LD}$ & $<$ LD & 0,01 & 0,01 \\
\hline CIANETOS & $\mathrm{mg} \mathrm{CN}^{\top} / \mathrm{L}$ & $<\mathrm{LD}$ & $<$ LD & $<$ LD & $<$ LD & 0,07 & 0,001 \\
\hline CLORETOS & $\mathrm{mg} \mathrm{Cl} / \mathrm{L})$ & 2 & 14 & 42 & 100 & 250,0 & 0,01 \\
\hline COBRE & $\mathrm{mg} \mathrm{Cu} / \mathrm{L}$ & 0,04 & 0,04 & 0,04 & 0,04 & 2,0 & 0,003 \\
\hline CROMO TOTAL & $\mathrm{mg} \mathrm{Cr} / \mathrm{L}$ & $\underline{0,25}$ & $\underline{0,93}$ & $\underline{0,25}$ & $\underline{0,67}$ & 0,05 & 0,005 \\
\hline FENÓIS TOTAIS & $\mathrm{mg} \mathrm{C}_{6} \mathrm{H}_{5} \mathrm{OH}$ & $<\mathrm{LD}$ & $<$ LD & $<$ LD & $<$ LD & 0,01 & 0,001 \\
\hline FERRO TOTAL & $\mathrm{mg} \mathrm{Fe} / \mathrm{L}$ & 0,10 & 0,10 & 0,12 & 0,18 & 0,30 & 0,005 \\
\hline FLUORETOS & $\mathrm{mg} \mathrm{F}^{-} / \mathrm{L}$ & 1,04 & 1,25 & 1,31 & 1,51 & 1,50 & 0,01 \\
\hline MANGANÊS & $\mathrm{mg} \mathrm{Mn/L}$ & $<\mathrm{LD}$ & $<$ LD & $<$ LD & 0,01 & 0,10 & 0,003 \\
\hline NITRATOS & $\mathrm{mg} \mathrm{N} / \mathrm{L}$ & 0,65 & 1,11 & 2,43 & 4,87 & 10,0 & 0,01 \\
\hline PRATA & $\mathrm{mg} \mathrm{Ag} / \mathrm{L}$ & $<$ LD & $<$ LD & 0,01 & 0,02 & 0,05 & 0,001 \\
\hline SÓDIO & $\mathrm{mg} \mathrm{Na} / \mathrm{L}$ & $\underline{457}$ & $\underline{506}$ & $\underline{895}$ & 1328 & 200,0 & 0,1 \\
\hline SULFATOS & $\mathrm{mg} \mathrm{SO}_{4}{ }^{2-} / \mathrm{L}$ & $<\mathrm{LD}$ & $<\mathrm{LD}$ & $<\mathrm{LD}$ & 56 & 250,0 & 1 \\
\hline ZINCO & $\mathrm{mg} \mathrm{Zn/L}$ & 0,05 & 0,06 & 0,06 & 0,06 & 5,0 & 0,02 \\
\hline $\begin{array}{c}\text { pH DO } \\
\text { SOLUBILIZADO }\end{array}$ & & 11,94 & 12,05 & 12,16 & 12,28 & N.A. & 0 \\
\hline
\end{tabular}

LIMITE MÁXIMO NO EXTRATO - ANEXO G (NORMATIVO) - PADRÕES PARA O ENSAIO DE SOLUBILIZAÇÃO (mg/L).

LD = LIMITE DE DETECÇÃO

N.A. = NÃO SE APLICA.

Resultados em Sublinhado - Valores acima do limite máximo no extrato.

\footnotetext{
${ }^{40}$ Idem à nota 36 .
} 
